\title{
JAILTON BEZERRA MELO
}

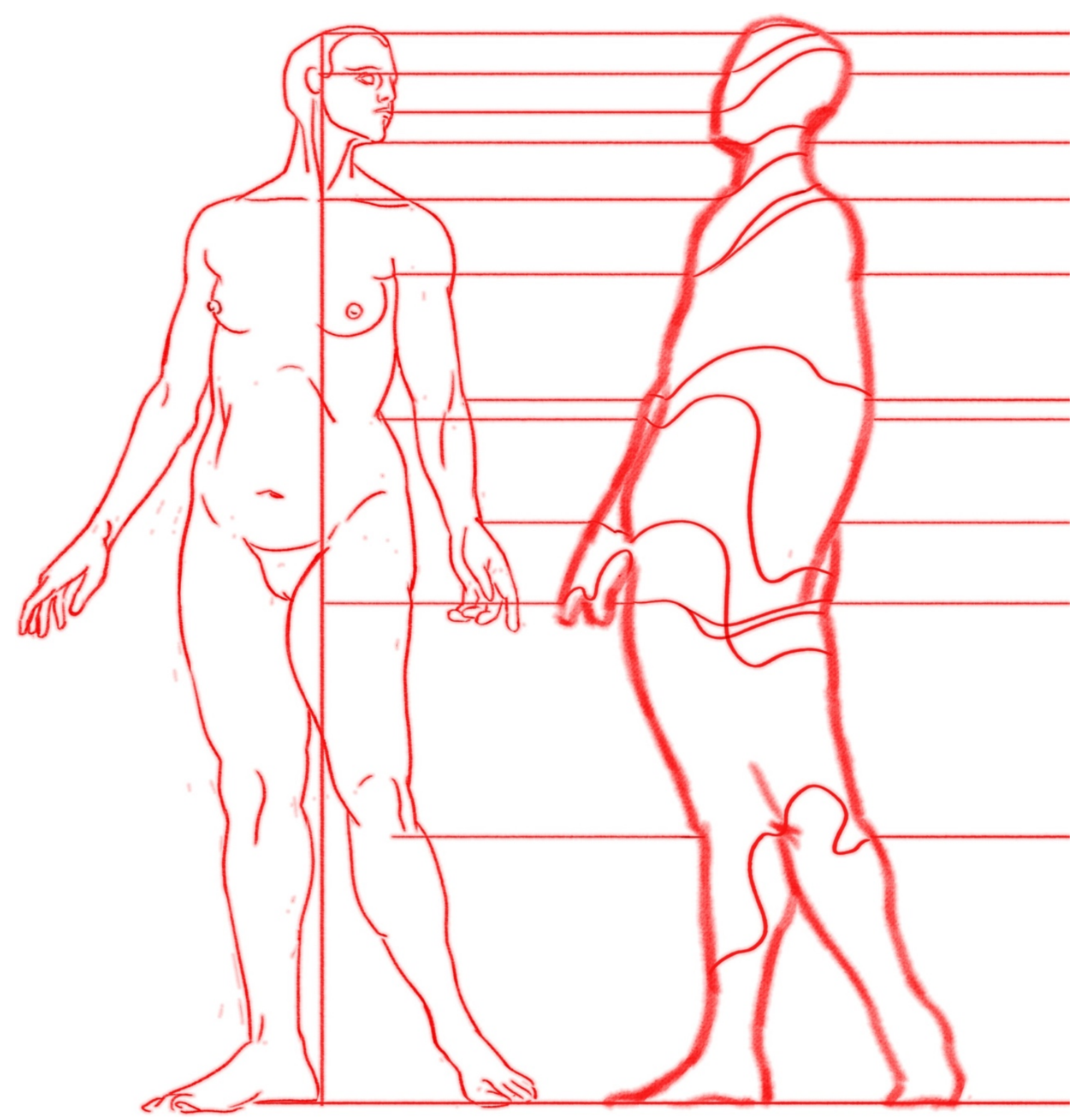

"Afasta de mim esse $\boldsymbol{C A L E - S E " : ~ n a r r a t i v a s ~ d e ~ c o r p o r a l i d a d e s ~ t r a v e s t i s ~ e ~ t r a n s ~}$ para uma ação clínica e política em psicologia 
UNIVERSIDADE DE SÃO PAULO - USP

INSTITUTO DE PSICOLOGIA - IP

\section{JAILTON BEZERRA MELO}

"Afasta de mim esse CALE-SE": narrativas de corporalidades travestis e trans para uma ação clínica e política em psicologia 


\title{
JAILTON BEZERRA MELO
}

"Afasta de mim esse CALE-SE": narrativas de corporalidades travestis e trans para uma ação clínica e política em psicologia

\author{
(Versão Original)
}

Tese apresentada ao Programa de Pós-Graduação em Psicologia Escolar e do Desenvolvimento Humano, da Universidade de São Paulo (USP), com finalidade de obtenção de título de Doutor em Psicologia.

Tese financiada pela Coordenação de Aperfeiçoamento de Pessoal de Nível Superior (CAPES).

Área de concentração: Psicologia Escolar e do Desenvolvimento Humano.

Orientadora: Profa. Dra. Henriette Tognetti Penha Morato 
Melo, Jailton Bezerra

"Afasta de mim esse CALE-SE": narrativas de corporalidades travestis e trans para uma ação clínica e política em psicologia / Jailton Bezerra Melo; orientador Henriette Tognetti Penha Morato. -- São Paulo, 2019.

$230 \mathrm{f}$.

Tese (Doutorado - Programa de Pós-Graduação em Psicologia Escolar e do Desenvolvimento Humano) -- Instituto de Psicologia, Universidade de São Paulo, 2019.

1. Corpo. 2. Identidade de gênero. 3. Travestilidades. 4. Transexualidades. 5. Fenomenologia Existencial. I. Morato, Henriette Tognetti Penha, orient. II. Título. 
Nome: MELO, Jailton Bezerra

Título: "Afasta de mim esse CALE-SE": narrativas de corporalidades travestis e trans para uma ação clínica e política em psicologia

Tese apresentada ao Instituto de Psicologia da Universidade de São Paulo (IPUSP), como parte dos requisitos para a obtenção do título de Doutor em Psicologia.

Aprovação em:

Banca examinadora:

Profa. Dra. Henriette Tognetti Penha Morato

Julgamento:

Profa. Dra.

Julgamento:

Profa. Dra.

Julgamento:

Profa. Dra.

Julgamento:

Profa. Dra.

Julgamento:

Profa. Dra.

Julgamento:
Instituição: IPUSP

Assinatura:

Instituição:

Assinatura:

Instituição:

Assinatura:

Instituição:

Assinatura:

Instituição:

Assinatura:

Instituição:

Assinatura: 
Aos corpos inconformados. 


\section{AGRADECIMENTOS}

À minha mãe, Maria, por toda sua força, luz e amor... por ter suportado o "ninho vazio"; e a meu pai, Dema (In memorian), por ter sido o guerreiro que foi... pelo calor de seu corporar que ainda habita meu coração.

À tia Nenê e tio Manoel, por terem feito de sua casa um ninho de cuidado e zelo.

A Rob e Meme, por terem sido meus pais, irmãos, amigos, acalento.

A Cícero, por seu amor e companheirismo. Seu corpo é presença; seu sorriso, um abrigo.

A meus amigos que estão "lá": Alê, Airon, Auris, Berg, Bruno, Gean, Jeff, Josimar, Juliet, Marta, Naty, Paulinho, Saulo, Venâncio, por terem sido cais, em meio ao caos que existia "cá".

A meus amigos que estão "cá": Erikson, Fernanda, Paola, Rob, Sara, Thiago, por serem lugar quando eu estava (ou estou) sem lugar.

Ao LEFE, pela acolhida, discussões, produções e ações - especialmente a Laiz (minha dupla de doutorado), André, César, Rosangela e Joice por terem sido tão cuidadosos e fraternos.

À minha orientadora, Henriette Morato (ou simplesmente Henri), pelo amor com minhas palavras... Você é tão especial, tão potente, que às vezes só penso que devo ser muito agraciado pela oportunidade que tive de receber e re-colher abraços seus.

À Carmem Barreto, pelo seu carinho e cuidado antes de minha vinda para "cá".

À Suely (Su), por ser minha "mãe de pesquisa"... por acreditar em mim, por ser "gente como a gente" e mostrar que a psicologia se faz com pés no chão. Obrigado pela leitura atenta.

À Marcia Couto, pelo calor e valor que deu à minha pesquisa.

À Fernanda, Joyce e Eduardo, narradoras e narrador desta pesquisa, por terem aceitado partilhar de suas histórias. Vocês foram fundamentais! Obrigado por serem corpo-todo-presentehabitado e por urgirem com grito o pedido de uma ação.

A todas travestis, mulheres transexuais e homens trans que experienciam diariamente a potência de seus corpos. Também àquelas e àqueles que, tendo o seu corpo como política, foram calados e flagelados: Dandara, Valéria, Quelly, Brenda Lee, Luana Muniz, Lourival e tantas e tantos outros... Esta tese não teria sentido se o corpo-voz de vocês não tivesse emergido.

Às equipes dos Centros de Cidadania LGBTI de São Paulo e do Transcidadania, por serem coerentes em suas práticas, mesmo quando o sistema quer soterrar e massacrar suas ações.

Aos professores e professoras do curso de Pedagogia da Faculdade Campos Elíseos, pelo carinho e encontros regados a gargalhadas.

À CAPES, pelo amparo e fomento à esta pesquisa. 
"A luta começou desde que percebi que meu corpo era proibido para mim mesma."

(Linn da Quebrada) 


\section{RESUMO}

MELO, J. B. (2019). “Afasta de mim esse CALE-SE”: narrativas de corporalidades travestis e trans para uma ação clínica e política em psicologia. (Tese de Doutorado, Instituto de Psicologia, Universidade de São Paulo).

A presente pesquisa parte de inquietações situadas na clínica psicológica em torno de suas confabulações acerca do corpo humano e da saúde. Tendo o retrato do corpo marcado pelo encerramento na materialidade física, encontra-se, nas experiências de travestis, mulheres transexuais e homens trans, outras possibilidades de compreensão para este corpo. Nesse sentido, orienta-se pela questão: Como tem sido a experiência de travestis, mulheres transexuais e homens trans, no que diz respeito às suas corporalidades, e quais experiências de cuidado essa população requer? O trabalho tem, portanto, como objetivo, compreender como seria possível pensar uma ação clínica e política a partir do encontro com histórias narrativas de mulheres transexuais, homens trans e travestis. Para isso, parte das experiências de três pessoas trans/travestis acerca de suas corporalidades, testemunhadas por meio do recurso da historiobiografia. Compreende, a partir de uma leitura fenomenológica existencial, que através do encontro com o corpo, outras possibilidades surgem, no que concerne às experiências de identidades de gênero, sexualidade e orientações sexuais. Propõe-se a refletir que é no corpo que acontece o processo de politização da existência, na medida em que é a partir dele que se iniciam e se encerram processos e fenômenos concretos e psicológicos, demarcando o lugar da diversidade e multiplicidade do corpo trans/travesti. O encaminhamento de tais questões revela os caminhos da exclusão, ou melhor, da inclusão precária, anunciando e denunciando práticas violentas nos âmbitos da saúde e da educação. A (in)visibilidade desses corpos (des)aparece nas instituições, em especial, nas de saúde, que passam a entendê-los por meio de uma adequação física via recursos tecnológicos (tais como o uso de hormônios e cirurgias redesignadoras). Com isso, a tese discute a transição social de corpos trans/travesti como marcada pela comunicabilidade de potência transformadora, esquivando-se de uma tutela médico-científica. Dessa forma, questiona o lugar da psicologia frente às existências dissidentes, aproximando-se a uma construção de uma ação clínica que se faz junto à política. Tal provocação incita interrogações no campo da clínica psicológica, refutando a "produção" de um sujeito psicológico ou um sujeito da psicologia. Nesse sentido, percebe-se que quanto mais a psicologia orienta-se pela aproximação com a medicina, mais perde sua função política dirigida ao cuidado humano. Assim, considera que o grito das corporalidades trans e travestis sinaliza que o modelo de psicologia, enquanto ciência, é falho para suas conjunturas e compreensões sobre as experiências de corpos diversos, revelando o desarranjo entre o poder e a violência em suas práticas.

Palavras-chave: Corpo. Identidade de gênero. Travestilidades. Transexualidades. Fenomenologia Existencial. 


\begin{abstract}
MELO, J. B. (2019). "Afasta de mim esse CALE-SE”: Narratives of transvestites and trans corporalities for a clinical and political action in psychology (Ph.D. Thesis, Institute of Psychology, University of São Paulo).
\end{abstract}

This research starts from concerns in the psychologycal clinic about its confabulations around the human body and health. Having the portrait of the body being marked by the limitations of physical materiality, one finds, in the experiences of transvestites, transexual women and trans men, other possibilities of understending the body. Therefore, this research is guided by the question: What has been the experience of transvestites, transexual women and trans men, regarding their corporalities, and what care experiences does this population requires? Thus, this work aims to understand how it would be possible to think in a clinical and political action from the encounter with narratives of transvestites, transexual women and trans men. For this, starts from the experiences of three transexual/transvestite people about their corporalities, witnessed through the resource of historybiograph. Understands, from a existencial phenomenologycal reading, that through the encounter with the body, other possibilities arise, regarding the experiences of gender identities, sexuality and sexual orientations. This work proposes do consider that it is in the body that the politization of existence process takes place, since it is from the body that concrete and psychologycal phenomena begin and have their endings, demarcating the place of diversity and multiplicity of the trans / transvestite body. The referral of such questions reveals the paths of exclusion, or rather, precarious inclusion, announcing and denouncing violent practices in health and education. The (in) visibility of these bodies (dis) appears in the institutions, in particular in health care ones, which come to understand them through a physical changing via technological resources (such as the use of hormones and surgeries redesignadoras). Thus, the thesis discusses the social transition of trans / transvestite bodies as marked by the transformative power communicability, dodging a medical-scientific tutelage. This way, this work questions the place of psychology in face of dissident existences, approaching the construction of a clinical action that is made together with politics. Such provocation incites questions in the field of psychological clinic, refuting a "production" of a psychological subject or a subject of psychology. Such provocation incites questions in the field of psychological clinic, refuting a "production" of a psychological subject or a subject of psychology. In this sense, one realizes the more psychology oriented by the approach to medicine, the more it loses its political function directed to human care. It therefore considers that the cries of transexual and transvestite corporalities sinalizes that the model of psychology, as a science, is flawed for its conjuctures and comprehensions about the experiences of different bodies, revealing the breakdown between power and violence in their practices.

Keywords: Body. Gender Identity. Transvestilities. Transexualites. Existencial Phenomenology. 


\section{SUMÁRIO}

1 "COMO É DIFÍCIL ACORDAR CALADO": do espanto ao olhar pela janela a uma (possível?) imersão

2 “SE NA CALADA DA NOITE EU ME DANO”: démarche de uma metodologia

2.1 O percurso: experiência-narrativa.

2.2 O recurso: historiobiografia. 28

2.3 A via de acesso:entrevista narrativa e diário de bordo como instrumentos 29

2.4 O contato: circunscrição de um campo.

2.5 O caminho: da escuta, do testemunho e da autenticação.

3 "QUERO LANÇAR UM GRITO DESUMANO, QUE É UMA MANEIRA DE SER ESCUTADO": (des)encontros com corporalidades

3.1 "De muito usada a faca já não corta": o corpo-dobra de Fernanda na solidão da cozinha.....

3.2 "Como é dificil, pai, abrir a porta": o nascimento de Joyce na intimidade do quarto 73

3.3 "Essa palavra presa na garganta": o orvalho de Eduardo no jardim de inverno 96

4 "CÁLICE": a ciência, os manuais e a psicologia como categorias (de)formadoras das transexualidades e travestilidades.

4.1 "Como beber dessa bebida amarga": a ciência como juíza.

4.2 "Tragar a dor, engolir a labuta": o DSM-5 e a CID-11 como produtores de formas e fôrmas para os gêneros. 146

4.3 “Mesmo calada a boca, resta o peito": encontros e desencontros dos corpos trans no SUS. 155

4.4 "Silêncio na cidade não se escuta": o discurso psicológico e a vigilância dos corpos trans

5 “ATORDOADO, EU PERMANEÇO ATENTO": a pluralidade da condição humana de e para o corporar de travestis, mulheres transexuais e homens trans

5.1 "Pra a qualquer momento ver emergir o monstro da lagoa": corpos e (bio)poder... 177 
5.2 "De muito gorda, a porca já não anda”: discursos per-versos, práticas violentas ... 183

5.3 "Talvez o mundo não seja pequeno": corpo público-privado.

5.4 "Outra realidade menos morta": dos corpos travestis e trans para uma ação clínica e política em psicologia

6 "AFASTA DE MIM ESSE CALE-SE": um sentido para a pluralidade cotidiana de corporalidades trans e travestis - ou da ação clínica psicológica?

REFERÊNCIAS 210

APÊNCIDE 216

Termo de Consentimento Livre e Esclarecido (TCLE) 217

ANEXOS

Notas sobre o texto: por um outro olhar 221

Profa. Dra. Suely Emilia de Barros Santos

Parecer Consubstanciado do Comitê de Ética (CEP) 227 


\section{1 “COMO É DIFÍCIL ACORDAR CALADO”: do espanto ao olhar pela janela a uma (possível?) imersão}

"Eu ando pelo mundo prestando atenção em cores que não sei o nome", seja pela letra de Adriana Calcanhotto, cantada pela mesma, por Belchior, por Renato Russo, por Los Hermanos, por Inês Brasil ou por Jaloo... andar pelo mundo diz de uma experiência que aguça os sentidos. Cores precisam de nomes? Cores precisam de quadros, de esquadros? A experiência do olhar de quem está nesse mundo acompanha - ou deveria - acompanhar a démarche, os passos de uma criança: desalinhavando o nó, reconstruindo um sentido, pintando o corpo com cores (mesmo que ainda não sejam atribuídas a nomes).

A experiência de quem olha é mais que uma sensação orgânica. Olhar e depositar o olho em alguma passagem é guardar-se em memória (mesmo que depois ela seja esquecida). Mas quem olha com afinco - aliás, quem vê e se entrelaça - tem seu corpo demarcado pela artimanha das veredas que é emprestar seu corpo a uma tatuagem. Fazer do corpo uma tela em que o pintor pode emprestar-se para viver esse próprio mundo à sua maneira.

É nessa experiência da viagem que, imerso em horizontes que demandam o "algo novo", o pesquisador-viajante se abre para aquilo que lhe vem ao encontro ou aquilo em que ele sai a conhecer e, dito isto, parece inaugurar "algo novo" em seu próprio existir. As ideias préconcebidas são postas em xeque e ele se pergunta se olhar pelo prisma, pelo quadro, pelo esquadro, faz sentido. Aliás... ficar da janela faz sentido?

Transitando entre seus modos - ora viajante ora turista -, o acompanhar da viagem demanda que o corpo inteiro se aguce. Não é por um órgão em si, mas sim pelo corpo que as coisas se dão a conhecer. É o corpo que, em sua magnitude, transborda vida: o corpo é morada, é habitação, é trajetória, mas corpo também é pôr ar e cor ou cor-por-ar.

Durante a graduação, li um livro chamado A fábrica de Interiores: A formação psi em questão, de Luis Antonio dos S. Baptista. A capa do livro já era provocativa: engrenagens que tinham estampadas a imagem do Homem Vitruviano, de Leonardo da Vinci. Engrenagens! A Fábrica de Interiores já sinalizava que o corpo estava aprisionado: era um homem milimetricamente pensado, respeitando espaços, normas e condutas e, mesmo girando em engrenagens, continuava no seu círculo-quadrado. Com o passar das páginas, via, mais ou menos, títulos como "A escuta clínica escuta o silêncio ensurdecedor?", "A escuta clínica escuta o equilíbrio da bailarina?" e questionava que escuta clínica era essa... 
Desde os primeiros dias da graduação, escutava dos professores e dos colegas de turma esse tal termo, escuta clínica, e sempre repetia isso - apesar de sempre ter questionado o sentido que o termo trazia. Foi quando, mais ou menos, no quinto período, uma professora questionou a turma, ao perguntar que escuta clínica era essa sobre a qual falávamos, e isso me instigou. Percebi que, antes de ser apenas um ato de mergulhar no sentido da audição, essa escuta dizia de um lugar sem lugar que era preciso se adentrar, viajar. Mais do que esse ato, deveria ser propriamente ação em direção a acolher o que (des)velava-se em narrativas e silêncio nesta mesma (possível) viagem.

A partir do refletir sobre que escuta era essa que se dava no trânsito entre o narrar e o silêncio, entrei em contato com a fenomenologia existencial, especialmente com os escritos do filósofo Martin Heidegger. Mergulhando em sua lente compreensiva, pude começar a caminhar por um sentido de clínica que saía de um mero espaço físico, mas que se destinava em cuidado a uma inclinação para o outro. Inclinar, a partir deste modo compreensivo, era estar ali para.

Veio, então, o mestrado, para o qual pesquisei a experiência de amputação. Compreendi que não seria uma tarefa fácil, pois o corpo pedia justamente por esse ouvido atento que escuta... Aliás, pedia por um corpo atento que escuta. Nesse trânsito, por meio da compreensão de clínica amparada por um olhar embebecido da analítica heideggeriana, outro sentido foi dado ao corpo: deixava de ser apenas um objeto, carne, para ser um modo de experiência pelo qual se habita o mundo.

A pesquisa inteira foi traçada pelo rompimento com um modo habitual de existir que acontece ao habitar o mundo a partir de uma nova metamorfose e história no corpo. Aos passos de terminar a pesquisa, indaguei o lugar da clínica psicológica nessa compreensão de corpo. A clínica teria subsídios para isso? A escuta clínica escuta o corpo? Ou melhor: Nós, psicólogos e psicólogas, escutamos o corpo?

O lugar de clínica, que foi tecido e alinhavado em minha formação, revelava que não era somente "se abrir" ou ter um ouvido "atento" ao que se escutava. Ali, na prática, ficava evidente que é o psicólogo o instrumento de sua própria ação. (Des)Tecendo e (des)alinhavando caminhos e percursos, a narrativa de quem se deixa marcar pelas histórias revela uma afetação que, sorrateiramente, constrói tatuagens na existência, no corpo do próprio psicólogo. Ali está feito: é, ele próprio, um Arlequim.

Por este caminho, a ideia de "sou um corpo" dava lugar a "habito um corpo" e configurava-se, para mim, como um assombro. Assombrou-me muito. Era estranho escutar pessoas falando - não com essas palavras - que não habitavam aquele corpo. Mais estranho ainda era poder, dali em diante, me deparar com uma questão que não me era tão clara ainda e 
que, durante a defesa do mestrado, foi sinalizada por um dos membros: Qual o lugar do corpo na sua vida?

Para esta questão, ainda não tenho uma resposta clara - nem sei se isso seria possível. O que comecei a refletir é que nem sempre o corpo abraça aquilo que lhe é posto e que a ele não cabe seguir uma via crucis. Abrindo um parêntese, lembro que, ainda na alfabetização, na disciplina de "Ciências", foi solicitado que desenhássemos um corpo humano e identificássemos "cabeça, tronco e membros superiores e inferiores". A tarefa não foi acatada por mim, em meus primeiros anos de idade, e apenas desenhei o corpo, sem apontar onde ficava a cabeça, seu tronco e seus membros. Óbvio que, ao não atender à tarefa científica, como cobrava a disciplina, o resultado não foi bom. E cobrei-me.

Parece que as ciências naturais empreendem uma explicação das funções corporais como meramente causais, observadas a partir de uma leitura que visa a uma organização dos órgãos e, assim, desse amontoado de órgãos, se tem um corpo. Há uma decomposição dupla: o corpo se de-compõe - ou seja, se fragmenta e desaparece (se esgota). Talvez esta decomposição dupla seja explicada por si só: de tanto dividi-lo, ele acaba se perdendo em partes cada vez menores e, de tanto se compor, acaba se aglomerando como emaranhado, um quebra-cabeças complexo - ou seria complexado?

Compreendo que, nestas circunstâncias em que o corpo é colocado passivamente, é denotado um lugar de reafirmação sobre o qual precisamos refletir. Soa-me preocupante o lugar incumbido ao corpo e é sobre esta tarefa que sou convocado, cada vez mais, a me debruçar. Parece que é fácil ver o corpo como materialidade e sinônimo de aprendizagem, mesmo que esteja morto. Difícil mesmo parece olhar para um corpo e não pensar em vida. Aliás... olhar para um corpo (mesmo que morto) e não pensar naquela vida.

Sem dúvidas, todas estas questões perpassam a formação dos profissionais que lidam com o corpo. Ou melhor, que lidam com gente. Por curiosidade, pesquisei alguns cursos de Psicologia e percebi que poucas são as instituições de ensino superior que trazem em suas ementas temáticas relacionadas às questões do corpo. Será que a Psicologia não teria uma dívida com isto?

Por outro lado, em cursos de saúde, desde os períodos iniciais, muitas disciplinas sobre o (ou seria um?) corpo é parte constituinte da formação do futuro profissional. Mas... em que medida estes corpos não são meramente substâncias com o intuito de serem desmistificados, destruídos, destituídos e dessacralizados? Será que, nestes cursos de graduação, a ideia de educação se funda e finda numa experiência que transmite significados para partes e membros, mas não um sentido para o corpo? 
Do Arlequim ${ }^{1}$ que sou, viajante e itinerante, recebo um convite para fazer parte de uma equipe multidisciplinar em um serviço de atendimento para a população LGBTI $^{2}$ da Prefeitura de São Paulo. O dispositivo, Centro de Cidadania LGBTI - Luana Barbosa dos Reis ${ }^{3}$ - Zona Norte, atua basicamente em dois eixos (assim como os demais dispositivos espalhados pelo município): 1) defesa dos direitos humanos: prestação de serviços jurídicos, de psicologia e de serviço social, focados em demandas de violações de direitos, como discriminação, LGBTIfobia $^{4}$ e outros tipos de violência e 2) promoção da cidadania LGBTI: com sensibilizações da rede de cuidado de saúde, assistência social e educação, a fim de delinear estratégias de atendimentos que se tornem efetivas na garantia de direitos da população LGBTI.

Em contato com as lutas que envolviam gênero e poder, tanto em minhas andanças no mundo acadêmico quanto na prática psicológica em assistência social, questionava o papel imposto ao corpo abraçar, refletindo, também, o papel dessa clínica na construção de sentido. Isto tornou-se possível na tentativa de se aclarar uma nova possibilidade de pensar o corpo senão pelo prisma da carne, do sexo ou da binariedade.

A tarefa não parece ser simples, pois não são só ouvidos ou olhos, mas o corpo inteiro que pedia atenção. Em contato com estas lutas, o lugar do distanciamento, da violência, da negligência e da recusa eram sinalizados a todo o momento, denotando a importância de esses corpos serem escutados "por inteiro", não apenas em detrimento de um sexo biológico, tal como a sociedade, calcada na cisheteronormatividade e patriarcado ${ }^{5}$, construiu suas lógicas.

Nessas lutas, e no contato com usuários(as) dos serviços aos quais me destinei, instigava-me a experiência de mulheres transexuais, homens trans e travestis ${ }^{6}$, no que tange ao corpo. Documentários, entrevistas em jornais e revistas, pesquisas, entre outros, apontavam para essa necessidade de pensar que corpo transitório era este. Trata-se de um corpo que não

\footnotetext{
${ }^{1}$ Referência ao personagem Arlequim, de Michel Serres.

${ }^{2}$ Sigla que compreende atualmente a população minoritária de lésbicas, gays, bissexuais, travestis, transexuais e pessoas intersexo, no Brasil.

${ }^{3}$ Luana Barbosa dos Reis, mulher preta, lésbica, pobre e da periferia do interior de São Paulo. Foi agredida até a morte pela polícia militar durante uma abordagem em sua rua, em 13 de abril de 2016. O Centro de Cidadania LGBTI da Zona Norte é o quarto centro criado na capital do estado e recebe o nome em homenagem à Luana.

${ }^{4}$ Termo que engloba toda a população LGBTI no que diz respeito às violências sofridas por esta população. $\mathrm{O}$ termo era antes conhecido apenas como homofobia, mas, em detrimento das lutas de identidade de gênero e respeito à diversidade da própria população LGBTI, o termo foi abrangido para que melhor englobasse, além da homofobia, a especificidade da violência destinada aos outros grupos da população (lesbofobia, bifobia e transfobia). Os termos são usados separadamente quando há necessidade de frisar determinado grupo em determinada situação.

${ }^{5}$ Entendido, grosso modo, como o sistema social baseado no controle do macho sobre a fêmea. Neste sentido, é estrito o entrelace do atributo sexual e a recusa da igualdade de gênero, pois esta não se deixa ver nos espaços em que há esse controle - em especial, na cultura brasileira, em que ainda a mulher é colocada à margem.

${ }^{6}$ As categorias "travesti", "mulher transexual" e "homem trans" estão relacionadas a uma autodenominação e autoafirmação. Cada uma destas categorias utiliza de uma denominação própria que tem a ver com sua historicização e demarcação política no modo como compreendem suas identidades e seus corpos.
} 
respeita as regras impostas pela biologia, fisiologia, anatomia. Como poderia, então, falar que era um corpo objeto? Como poderia pensá-lo apenas pelo seu "papel” imposto por uma ordem de nascimento?

Esses corpos trans $^{7}$ gritavam aos meus olhos: corpos que se mutilavam; corpos que tentavam se modificar de inúmeras maneiras; corpos que não cabiam naqueles corpos impostos; corpos que sofriam preconceito; corpos que sofriam violência; corpos que eram escutados por um prisma que não lhes competia...

Neste caminhar, ainda que pesquisas não só na Psicologia, mas nas Ciências Sociais, Filosofia e Antropologia não delimitem "terminações", por acreditarem que são as nuances o que envolve tal universo - em especial as nuances "sexo", "gênero" e "orientação sexual" -, percebo que tais elementos são oriundos de uma mesma problemática: a formação. Assim, importa elencar, mesmo que minimamente, o que compreendo por cada nuance citada, no intuito de conduzir o leitor a uma aproximação do universo LGBTI, pela qual esta tese se destinará.

Sexo, ou "sexo biológico", é uma categoria que atravessa a genitalidade. É a ordem de nascimento, “Nasceu menina!", "Nasceu menino!", identificada pelo órgão genital da criança, ou seja, suas gônadas. Gênero é um construto social que, diferentemente da categoria "sexo", não é simplesmente dado por uma força biológica, mas é um repertório que diz do lugar de "sentir-se" e identificar-se homem, mulher ou travesti. Extrapola a genitalidade e perpassa por toda uma esfera social, cultural, política e estética. Já a orientação sexual diz respeito às relações afetivo-sexuais que se tem, o modo como as pessoas se relacionam, desejam e sentem para com as demais. Assim: SEXO é diferente de GÊNERO, que é diferente de ORIENTAÇÃO SEXUAL, e nenhuma das três precisa estar em conformidade uma com a outra.

Todos esses três elementos já tinham sido estudados por mim na graduação, na qual sempre tive contato com temáticas que atravessavam a questão de gênero. Apesar de minha tímida aproximação com a temática e os estudos ingênuos, nunca foi uma questão a ser melhor investigada por mim, por acreditar que, apesar da notória importância, havia algo que me distanciava do assunto. À época, considerava essa atitude como longínqua de uma discussão que transpassasse outras nuances e não somente a diferenciação entre gênero e sexo biológico, como talvez compreendi, ainda em minha leitura "pueril".

\footnotetext{
${ }^{7} \mathrm{O}$ vocábulo "corpos trans" engloba, neste trabalho, as corporalidades de travestis, mulheres transexuais e homens trans. Ainda que o termo "trans" não compreenda todas as singularidades do modo como cada experiência de corpo de travesti, mulheres transexuais e homens trans, o termo é compreendido como uma categorização de estudo, representando um "termo guarda-chuva".
} 
No entanto, ao refletir sobre meu afastamento da temática, entrando em contato com as lutas de poder que suscitaram numa nova aproximação e, posteriormente, com uma contratação como psicólogo para trabalhar diretamente com a população LGBTI, me vem novamente a questão: por que fugi da temática?

Eu construí um armário. Aliás, as pessoas que me circundavam, em sua maioria, incumbiram a mim, cada uma, um armário. Dos variados armários que tive, lutava para romper as dobradiças, mas toda força que fazia era inviável em meio aos gritos que rugiam fora dele. Decidi apenas olhar da janela, perdendo o olhar curioso de quem viaja.

Fui obeso na infância. O que chamam de bullying era recorrente. Aliás, ser gordo e ser uma criança afeminada, numa cidade pequena do interior de Pernambuco, eram sinônimos de insucesso. Vivi uma adolescência "heteronormativa", porém "revoltada". Dos insultos sofridos e calados, deixava gritar o meu corpo gordo e afeminado. Os moldes algozes que encontrei diziam de um distanciamento comigo mesmo: por que não cabia em meu corpo, mas me fazia caber num "armário"?

"Tem dor que dói no corpo que não tem olho que enxergue ${ }^{8 "}$. Uma frase que pesa. $\mathrm{O}$ olho de quem vê não acompanha intrinsecamente a experiência de quem vive. A gente cresce, torna-se adulto. Tornar-se adulto é, aliás, um pedido de todas as outras pessoas e circunstâncias que lidamos na vida cotidiana. Viver, habitualmente nesta direção de cobrança e solicitações, perpassa campos sobre os quais, muitas vezes, não paramos para refletir. O que isso tudo tem a ver com minha pesquisa? O que tudo isso tem a ver com formação? O que isso tem a ver com ciência?

A ciência só consegue captar o preto e o branco. Mas há algo entre os dois que ela não dá conta: o cinza. Pensar no cinza é poder, também, abrir espaço para se pensar os furos e os percalços que encontramos em nossa formação acadêmica e que, de certo modo, vão implicar em nossas práticas profissionais.

Desta feita, por esta alternativa em existir e ser aclamado, o corpo, no decorrer do tempo, acabou marginalizado, escondido. Em busca de uma racionalização da massa corpórea e do organismo humano, a medicina inaugurou esconderijos para o acontecer do corpo, ou melhor, para o não-acontecer. Assim, a medicina passa a escrutinar o organismo e se familiarizar com ele, descentralizando cada vez mais a singularidade do paciente. Os sintomas "subjetivos" que fazem parte da existência da pessoa são esquecidos, como se a raiz - ou melhor, a semente - da problemática do corpo fosse sua doença.

\footnotetext{
${ }^{8}$ Trecho retirado do curta-metragem brasileiro "Ainda sangro por dentro" (2016), de Carlos Segundo.
} 
Em contrapartida, esse poder absoluto da medicina causa uma reviravolta em todas as ciências - desde as ditas "duras" até as ciências humanas e sociais - pelo fato de lidarem com questões que se constituem ou tangenciam o existir humano e, assim, participarem direta ou indiretamente do fenômeno do corpo.

Este deslocamento põe em xeque questões que não somente se configuram como primordiais, mas que, por si só, são problemáticas. Primordiais porque estas ciências retificam pensamentos e constroem direções que geram horizontes compreensivos, deixando evidente que não há um consenso; e problemáticas porque ratificam, amparadas por uma lógica de desalinho, a partir do pensamento moderno, que as questões que não são palpáveis e mensuráveis não serviriam para os crivos do modelo científico em voga.

A partir dessa lógica científica, as questões que pedem por espaços e olhares que não transpassam os modelos da mensuração e observação científica acabam por se tornar “confabulações". É o caso do corpo na psicologia e, mais ainda, é o caso dos corpos trans para as ciências da saúde.

Ainda no trabalho no Centro de Cidadania LGBTI, fomos convidados a fazer parte de um grupo GBTT $^{9}$, que desde o início de 2016 se reúne no Centro de Acolhida Zaki Narchi, na Zona Norte de São Paulo. O grupo em questão, denominado “Grupo Valéria”, é composto por homens gays, travestis e mulheres transexuais, que se reúnem uma vez por semana para uma roda de conversa no próprio Centro de Acolhida que frequentam. Foi assim denominado depois que uma travesti (Valéria), que frequentava o centro, faleceu em decorrência de negligência médica. O grupo se reúne por perceber a necessidade de se falar sobre que especificidade é esta de ser GBTT, discutir políticas públicas que englobam seus direitos e por poderem narrar suas experiências, ou melhor, pelo grupo se mostrar como um lugar do corpo tomar voz.

Já no primeiro contato com o grupo, o lugar (que não é dado) para a fala e para o cuidado nas instituições públicas é revelado. Uma das travestis fala "Bom... tudo é muito complicado pra gente, porque a gente vive no sub do submundo... quer dizer... além de a gente ser LGBTTI, a gente também está em situação de rua, o que deixa a gente mais exposta ainda.". Outra pessoa fala "Todo mundo sabe que o que aconteceu com Valéria foi negligência médica. A mídia abafa. o CRM abafa. Isso tudo porque se trata de um sub do submundo.”.

\footnotetext{
${ }^{9} \mathrm{O}$ acréscimo do segundo "T" ainda é uma luta no próprio Movimento. O intuito é de ratificar que apenas um "T" não diz das especificidades do grupo, ou seja, que travesti e transexual não tem a mesma configuração (seja ela de identidade, experiência, sexualidade e corpo). O grupo em questão insere este outro "T" justamente nesta direção de frisar as singularidades em meio ao plural, que as travestilidades são especificidades outras e pedem por compreensões outras de corpo e experiência.
} 
O "sub do submundo" parece revelar escombros, onde tudo é escondido, colocado em caixas e "abafado". Lembra-me um porão, um lugar empoeirado, onde é melhor não mexer, porque a poeira sobe. No contato com o Grupo Valéria, percebi que existem fronteiras onde o corpo é convidado a transitar. É preciso não de caixinhas para se guardar as letras L, G, B, T, T, I, mas é preciso jogar toda essa poeira para cima, para que ela, ao menos, provoque um espirro. Se algo com essa poeira é mobilizado em nosso corpo, é preciso cuidar disto. Mas não porque em nós provocou esta reação, e sim por sabermos que a poeira está lá, e que só é chamada de poeira (algo reduzido a pó) porque algo se fragmentou em pedaços. Mas o corpo pesa... não só por ser matéria, mas por ter importância.

O Grupo Valéria mostrou-se muito importante em meu caminhar. Este grupo se mostra como (r)es(x)istência. Algumas meninas que compõem o grupo foram convidadas a participar de um clipe da artista Linn da Quebrada ${ }^{10}$, no qual, no início do clipe, aparecem os dizeres: " $E$ ' o seguinte, amiga: a bicha pode fazer um pedido? Pode? Ai, arrasou! Primeiramente obrigada por essa educação. Tentei falar com várias pessoas e ninguém me deu atenção, só porque sou travesti. Pior coisa do mundo, gata, é a gente não ter atenção. Faz essa linha com a bicha, gata, que deus vai dar em dobro pra senhora.".

Para quem a bicha pode fazer um pedido e ele ser escutado? Como voltar a atenção a um pedido, a um olhar? O corpo periférico da pessoa trans e da travesti parece, sim, ser fronteira... mas para elas! Para o mundo "lá fora", ele parece ser limite. A quem ou a que ele se limita? Ficaremos da janela?

O limite se apresenta no cotidiano de travestis, mulheres transexuais e homens trans. Começa em casa, no "seio" da família, vai à escola, à farmácia, às ruas... vai onde se dá limite. O limite acontece onde ele é criado. A voz é calada e o ouvido tapado, os olhos cerrados para que não se veja. Nem o tato ou o paladar se fazem presentes. Tudo é deixado à margem, à periferia, no sub do submundo, para que, se a poeira levantar, se levante longe. Estabelecido o limite, a vida cotidiana acontece, mas lá fora. E como fica a fronteira de quem, em seu corpo, traz as marcas do limite?

“A gente não procura um serviço de saúde, um postinho de saúde, alguma coisa do tipo... porque a gente sofre preconceito. Começa pelo nosso nome social ${ }^{11}$. Uma vez fui num

\footnotetext{
${ }^{10}$ A artista se autodenomina em sua página do Facebook como "Bicha, trans, preta e periférica. Nem ator, nem atriz, atroz. Bailarinx, performer e terrorista de gênero", denotando a quebra de padrões e a importância em se pensar a especificidade da população LGBTI, em especial ao movimento norte-americano Queer, que culminou como importância de também ser pensado no Brasil.

${ }^{11}$ Nome social diz respeito ao nome com o qual a pessoa se identifica e pelo qual quer ser chamada. Diferentemente do nome civil (ou nome de registro), o nome social é um nome que resguarda toda uma identidade, uma vez que, primeiramente, é dado pela escolha da própria pessoa. No campo da saúde, a Portaria $n^{\circ} 1.820$, de 13 de agosto de
} 
hospital e não respeitaram meu nome social... me chamaram pelo nome de registro. Eu me levantei e nada disse... mas, mana... eu com um corpo desse, de mulher, vem lá alguém e me chama com nome de homem!!??". A fala de Tulipa ${ }^{12}$ transborda naquilo que percebo haver um distanciamento - distanciamento este que reverbera nas práticas de cuidado em saúde para o público trans e travesti.

Nesse ínterim, a pesquisa pretende compreender como seria possível pensar uma ação clínica e política a partir do encontro com histórias narrativas de mulheres transexuais, homens trans e travestis. Tal questão tornou-se permissiva por entender que as práticas em saúde voltadas a esta população geralmente estão interligadas ao processo transexualizador, não dando conta das especificidades de suas experiências. Passo a compreender que pensar uma ação clínica e política junto a esta população possibilitaria tematizar e reunir questões para além do fazer psicológico, que indicaria readequações corporais, aludindo a uma ação implicada no cotidiano.

Assim sendo, a pesquisa pretende refletir como travestis, mulheres transexuais e homens trans compreendem suas existências no que diz respeito a experiências de suas corporalidades; cartografar a percepção de cuidado voltado às demandas de readequações corporais à identidade de gênero ${ }^{13}$ e problematizar e propor espaços de conversação sobre as especificidades de uma possível ação clínica e política que se debruce sobre as experiências trans e travestis.

Nesta direção, diversas pesquisas e documentos revelam que há um distanciamento das práticas de cuidado de profissionais de saúde em torno da população LGBTI e, mais fortemente, em torno da população $\mathrm{T}$, que se mostra como a população mais olvidada no próprio movimento. As pesquisas denotam esta presença - ou ausência - da população T nos espaços

2009, publicada no DOU, já dispõe sobre a possibilidade de resguardo do nome social em qualquer documento viabilizado pelo sistema de saúde gerido pelo Sistema Único de Saúde (SUS). Em 28 de abril de 2016, pelo Decreto $\mathrm{n}^{\circ} 8.727$ da Presidência da República, foi estabelecido que os órgãos e as entidades públicas devem também adotar o nome social como premissa do respeito e reconhecimento da identidade de gênero. Hoje, a luta pelo nome social deu início à luta pelo nome civil, pois é o nome, enquanto legitimado civilmente, que "estabelece", minimamente, uma possível cidadania, motivo este que resultou no Provimento 73/2018, do Supremo Tribuna Federal, que prevê a retificação do prenome em qualquer cartório de registro civil do país.

${ }^{12}$ Nome fictício para preservar a identidade da mesma.

${ }^{13}$ Apesar de o termo identidade ter aparecido em algumas notas de rodapé anteriores, julgo importante considerar algumas questões. Em fenomenologia existencial, o termo abarca uma noção "fechada" e que caracterizaria a pessoa numa essência fixa. Para Maldonato (2014), o termo identidade é uma questão "inscrita num horizonte pósmetafísico" (p. 17), que circunscreve e designa estabilidade definitiva, ou seja, impossibilitada de um poder-ser. Concordo com essa compreensão, inclusive porque as narrativas posteriores demonstram que não há uma única maneira de ser homem/mulher/travesti. No entanto, nesse trabalho, passo a utilizar o termo identidade de gênero tal como o movimento organizado de travestis, mulheres transexuais e homens trans requer, por aproximar-se de um reconhecimento de si no/a outro/a, pelo/a outro/a e com o/a outro/a, demarcando algo construído por um grupo a partir de suas especificidades. 
institucionais, uma recusa aos modos (e moldes) com que as instituições endereçam suas práticas.

Destarte, ao mesmo tempo em que tais pesquisas indicam esta necessidade de olhar e refletir sobre as práticas, parecem não levar em conta como a própria população sente-se envolvida na própria construção. Esta perspectiva desapropria uma possível coconstrução e a efetivação do que se pressupõe por participação política em saúde.

Portanto, esta pesquisa direciona-se à tentativa de articular um sentido possível para a experiência de corporalidades travestis e trans, possibilitando a reflexão de uma ação clínica e política junto a esta população. Este caminho é necessário, uma vez que eu, enquanto psicólogo, não posso falar pelas experiências, mas com estas pessoas. O caminho pretendido destina-se a passos integrados e entregados, revelando a aproximação, com o cuidado em testemunhar e não de apropriar-se de um lugar de fala que não é meu.

Neste sentido, a pesquisa pretende caminhar por um desalinho que perpassa desde conceitos históricos de corpo até novas compreensões do mesmo, dialogando com autores (Foucault, 2017; Vigarello, 2006) que retratam como tais compreensões subsidiam o pensamento ocidental atual. Endereça-se também a olhar para construções compreensivas de corpo a partir de estudiosos (Bento, 2006, 2011; Butler, 2009, 2015; Louro, 2007, 2015; Miskolci, 2013) que se debruçam sobre a temática de gênero como construção social performativa, bem como sobre o corpo como o lugar de acontecimento de transformações transeuntes.

Ademais, quando, nos escritos que sucedem, relacionar-me ao corporar, estarei me referindo ao modo existencial de "habitar o corpo", ou seja, habitamos o mundo corporalmente - tendo o gênero e a orientação sexual, por exemplo, como um conjunto que se revela no modo como experienciamos "este" corpo. Já quando relacionar-me a corporalidades, estarei falando de um determinado sujeito singular, "deste” sujeito, ou grupo em específico.

A partir da lógica de que a pesquisa pretende ser realizada com travestis, mulheres transexuais e homens trans, intenta-se também refletir a partir de alguns teóricos (Galli \& Vieira, 2013; Oliveira, 2014) como vem se delineando a prática de profissionais de saúde, em especial de psicólogos(as), apontando considerações para pensar este lugar (Figueiredo, 2014; Leite Jr., 2011).

Com toda essa construção que se pretende desenhar sobre tais práticas, evidencia-se que o olhar demandado a se debruçar, na tentativa de recolhimento de experiências e de acompanhamento de leituras acima frisadas, será em torno do pensamento de filósofos que 
comungam com a psicologia e que compreendem o humano como existencialmente fundante (Benjamin, 2012; Arendt, 2008, 2009, 2018a, 2018b).

No que tange a esse descortinamento, cuidar da saúde de travestis, mulheres transexuais e homens trans também diz de um cuidado em torno de questões voltadas ao corpo, um corpo em transformação e que, acima de tudo, é um corpo colocado à margem pelos padrões biológicos que fundam o conceito de saúde. Destarte, no que dedilha à compreensão de um corpo que foge às amarras de uma padronização biológica, os corpos trans são tidos como "desviantes" e desalojam toda uma lógica metafísica que rompe com a dialogia corpo feminino/corpo masculino. Afinal, o que diferencia um corpo "masculino" de um corpo "feminino"?

Assim, esta tese caminha na tentativa de reunir o que é falado sobre corporalidades travestis e trans, a partir da experiência de quem vive o corporar do corpo trans/travesti. Com o passar das andanças, entende-se que além de um problema de formação, é também um descaso o modo como práticas são destinadas - especialmente no campo da psicologia e da medicina.

Seguindo esta perspectiva, inicio questionando: por onde o pesquisador-viajante se deixa tatuar nessas (des)amarras do corpo? Por onde se emprestar a escutar e ver o silêncio gritante que habita em torno dos corpos trans? Por onde nós, viajantes ou turistas, que transitam "entre dois lados" nas instituições (e gostando de opostos), podemos dizer do quanto se é afetado? A quem nos endereçamos, para além do corpo que se vê? Continuaremos olhando $d a$ e pela janela? 


\section{2 "SE NA CALADA DA NOITE EU ME DANO": démarche de uma metodologia}

Escrever não é uma tarefa fácil, ainda mais quando nos é delegado escrever sobre um caminho. Narrar um trajeto nem sempre parece tranquilo, uma vez que neste caminhar, por entre pedras e elevações, o corpo cansa. Escrever é um dilema solitário. A pessoa que escreve corre o risco de se perder. A passagem, mesmo que conhecida, é aberta por entre uma nova chegada, uma nova saída, uma nova estadia ou um descanso quando os pés estão aflitos. Escrever sobre um caminho é também escrever uma história e, como toda história, só há um sentido se ela for comunicada.

As histórias são sempre carregadas de um caminho, marcadas duras penas, e nem sempre com um final feliz. O trajeto aqui escrito não carece de um final - pelo contrário, é sempre abertura para uma nova possibilidade, sempre projetado e erguido, porém inconstante. Como um viajante, as malas que se pega são guardadas onde quer que a pessoa vá, seja de barca, bicicleta ou por entre os relevos, a pé. Das malas que carregamos, optamos, na maioria das vezes, por levar apenas o que é necessário. Com a destreza que temos, às vezes levamos mais do que se precisa e, em meio à viagem, ficamos intranquilos por não ter deixado na mala algum espaço para se levar algo para casa.

Em casa, sentamos e pensamos sobre a viagem. As paisagens que vimos, os lugares a que fomos, os sorrisos que capturamos, os olhares de curiosidade, os sabores desconhecidos, os odores comunicáveis, acompanhados ou sozinhos, são sinônimos de contentamento por, de passo em passo, nossa marca ser feita em terra, em solo. Nem sempre o solo é firme, às vezes é sedimentado, noutras, arenoso, noutras, escorregadio. E daí quem narra um caminho corre o risco de se perder por entre estes solos. De trás para frente, a palavra "solos" (no plural, porém singular) é escrita da mesma maneira, mas apresenta-se como substantivo que traz, em si, possibilidades.

Esta tese, para mim, sempre foi marcada pela experiência, pelos solos, pelas histórias, pelas contações, pela vida. De início, inquietante e motivado a pensar em qual reflexão poderia trazer sobre as nuances do corpo, o desestímulo e o cansaço atingiram-me. Esta tese não precisaria ser ciência pura, ser descrita e inscrita como satisfatória para o mundo científico, bastaria que ela seguisse seu rumo, sendo recolhida como uma folha que cai no outono. Dois outonos se passaram e ela começa a tomar forma por entre os caminhos. Para onde ela vai, não poderei saber, sequer imaginar. De onde ela veio, talvez saiba, mas pelas camuflagens e itinerâncias que ela se fez, mesmo conhecendo-a, ainda lido com o assombro. 
Assim como as palavras, esta tese tem um sentido. Ela demarca minha abertura com a aproximação que tenho com o mundo. Ela irradia e reverbera em marteladas cada vez que uma nova tecla é pressionada, assim como um acorde de um piano. O desafio que se faz em contar este caminho pode ser um tanto quanto necessário em vias acadêmicas. No entanto, a escolha por contar deste caminho soa-me como uma démarche ${ }^{14}$ : alinhavado pelos primeiros passos, como uma criança que busca o novo, o desconhecido.

Escolhi fazer a tese que o caminho me revelou, muito mais do que a tese que queria ter. Alguma vez li que temos dois tipos de tese, a que queremos e a que é possível. A partir daqui, imerso por entre estas palavras, saliento que o que narrarei foi o caminho possível. Não por falta de perseverança ou pelo peso das malas, mas por entender que o tempo e o espaço estão atrelados à uma história, e, como em toda história, os eventos são subsidiados a partir de interligações, numa linearidade em termos de khronos e com limiares em termos de kairós ${ }^{15}$.

Desde a graduação, quando tive contato com a fenomenologia existencial, soava-me a estranheza de como, para nós que pesquisamos nesta perspectiva, é difícil chegar a uma questão de pesquisa. Não que seja dificultoso do plano da maturidade cognitiva, mas pela implicação que nós temos com a pesquisa, com o que ou com quem pesquisamos e com os eventos que nos tiram do lugar de detentores de um possível saber.

Desta feita, fica evidente que o caminho que escolhi e assumo revela o descortinamento de uma possibilidade em pesquisa, deixando espaço para que, neste caminhar, outras possibilidades sejam postas e historicizadas. Nesta direção, o olhar empreendido a partir da fenomenologia existencial e que foi endereçado nestas circunstâncias revela que toda história pessoal é carregada de um possível sentido da vida e, assim, abre caminhos para se pensar uma historiobiografia (Critelli, 2012).

A partir deste entrelaçamento, compreendo minha pesquisa, em termos acadêmicos, como uma pesquisa de "natureza" - ou seria condição? - qualitativa. Isso acontece por entender que o sentido das palavras, a elaboração de uma experiência e o desvelamento de circunstâncias que pedem por um aprofundamento de questões e ações, que o método vigente científico de causalidade e estatísticas presume, não dá conta (Minayo, 2002). Persigo essa perspectiva.

Para Souza (2014), o "produto" de uma pesquisa qualitativa é sempre uma invenção complexa, está sempre atrelado a uma preocupação de ordem social e diz das relações humanas e suas especificidades sem, necessariamente, estar atrelado a um único referencial teórico,

\footnotetext{
${ }^{14}$ Em francês, "providência".

15 Khronos e kairós, referem-se à compreensão grega de tempo "cronológico" e "existencial, vivido", respectivamente.
} 
paradigma ou disciplina. Sendo assim, enfatizo que os relevos que perfazem este escrito revelam a necessidade de olhar por múltiplas facetas, na tentativa de aclarar horizontes já vividos e, possivelmente, pensados para serem trilhados.

Para Critelli (2012), "Todo seguir adiante de nossa existência... tem por meta tornar reais as possibilidades que para nós se abriram através da resposta dada a tais questões. É dessa maneira que os homens se projetam...." (p. 11). Desta feita, esta pesquisa trilha a passos curtos, porém pesados, numa direção que acompanha o fenômeno tal como sua mostração, expressada a partir de uma lente compreensiva desvelada no pensamento de Martin Heidegger, comungada com autoras e autores. Neste sentido, para este filósofo, "o que se mostra, o se-mostrante, o manifesto.... isto é, aquilo em que algo pode se tornar manifesto, podendo ficar visível em si mesmo." (2012, p. 103), é o que é o cerne central da pesquisa, por compreendermos que é a partir de sua história via experiência que a humanidade consegue vislumbrar suas ações perante o mundo, os outros, as coisas e ela mesma.

Assim, a pesquisa de olhar fenomenológico, ao modo de Heidegger, se direciona a compreender o sentido daquilo que se manifesta. Deste modo, a presente proposta visa adentrar em uma compreensão do fenômeno a que se interroga, tal como se mostra, e a partir dele mesmo, para poder abrir outros horizontes compreensivos - horizontes estes que podem permitir uma reflexão sobre como são endereçadas as práticas de cuidado em saúde a pessoas trans.

Opto por um modo que leve o leitor pela mão, a fim de que ele conheça o meu caminho trilhado. Destaco que 1) se trata de uma pesquisa na qual alinhava-se o fio compreensivo e, portanto, partilhado pela via de uma pesquisa qualitativa; 2) destina-se, pela lente compreensiva da fenomenologia existencial, em especial aos pressupostos de Martin Heidegger e Hannah Arendt; 3) concretiza-se via historiobiografia, assinalada como recurso por Dulce Critelli (2012), embebecida pelo pensamento arendtiano e conduzida pelas vias de acesso à narrativa, empreendida aqui pelas leituras advindas dos pensadores Walter Benjamin (2012) e Larrosa (2018).

\subsection{O percurso: experiência-narrativa}

Pela necessidade de melhor ser esclarecido o percurso, importa justificar a escolha pela itinerância numa pesquisa que se acossa numa perspectiva que deflagra o que comumente entende-se por ciência. Nesta direção, a escolha pela condição de ser qualitativa se revela no empreendimento de nuances que, muitas vezes, escapam do crivo científico. Para Oliva (2014), 
o que se toma como conhecimento é feito de causas sociais. Os estudos que inventariam o que a ciência é para definir como deve a pesquisa ser feita são desqualificados pelo socioconstrutivismo como aprioristas.... não é da compreensão de como opera a razão que se deriva o entendimento da atividade científica - é pelo acompanhamento das práticas comunitárias que se conhece o ser da ciência. (pp. 43-44).

A ciência acabou sendo a unicidade, como se só existisse um único tipo de ciência, empreendida pela lógica da hipótese, mensuração, observação, avaliação, quantificação e conclusão. Por esta lógica, é evidente que as disciplinas das áreas humanas e sociais escapariam do rigor científico, sendo rechaçadas como uma "menos valia". A propósito, não como parêntese, mas como uma ação política, durante a realização desta pesquisa, o governador do estado de São Paulo, Geraldo Alckimin, congelou bolsas de fomento da Fundação de Amparo à Pesquisa do Estado de São Paulo (FAPESP) para as ciências humanas e sociais, com a alegação de que tais fomentos deveriam ser destinados a pesquisas que produzissem, notoriamente, um ganho tecnológico e científico para o Brasil. No entanto, questiono: estaríamos, pois, destinados à obsolescência? Toda pesquisa, por ser científica, não deveria ter em seu arcabouço uma destinação a uma ação política?

Ao questionar isto, encontro, em Maciel (2014), que "a prática científica é um empreendimento coletivo. É uma prática humana dentre outras práticas humanas.” (p. 69), o que vai de encontro ao sentido de política: lugar de troca entre humanos, em suas relações de poder e saber (Arendt, 2009). Para além de uma contação do que possivelmente compreendese por ciência ou não, pensar por este viés parece fazer sentido, uma vez que, apesar de muitas vezes o caminho do pesquisador ser trilhado na solidão, a sua experiência e o produto de sua ação fazem-se em comunhão, em conjunto.

Em sua leitura, Souza (2014) compreende que "Os pesquisadores qualitativos enfatizam a construção social da realidade, a íntima relação entre o pesquisador e o que está sendo pesquisado, e procuram respostas para questões referidas à experiência social, como ela é criada, como ela é significada." (p. 87), o que nos possibilita refletir sobre o papel que nós, pesquisadores numa condição qualitativa, estamos destinados a ocupar. Tal leitura é emaranhada pela construção desta ação conjunta, engendrada na própria relação que se tem com o que ou quem se quer pesquisar, na sua implicação com o tema a ser questionado e nas nuances que apontam o sentido da analítica escolhida; ou seja, só é possível uma pesquisa qualitativa se ela se mostra atravessada pela destituição de um poder sobre outro, concentrada no sentido próprio da atitude política. 
Nesta dimensão, a partir não só do que se entende por ciência, mas embasado pelo olhar da fenomenologia existencial para estas nuances, a práxis desta pesquisa, em detrimento da técnica moderna e do arsenal de instrumentalização que a ciência se caracteriza, solicita sair de uma mera informação sobre determinada temática assuntada para empreender um fio condutor desta "contação". Esta dimensão que, por muito, pareceu ser perdida no pensamento ocidental (Benjamin, 2012; Heidegger, 1959; Larrosa, 2018) é retomada por Benjamin (2012) como narrativa: a possibilidade de pôr em andamento as histórias vividas e as marcas provocadas pelo percurso da experiência do pesquisar. "É a experiência de que a arte de narrar está em vias de extinção. São cada vez mais raras as pessoas que sabem narrar devidamente.” (p. 213).

Para este pensador, a "arte de narrar" perdeu-se com o avanço da era da técnica, sendo deflagrada pela era da informação. Nos tempos atuais, isto é notório, a começar pelo que nos está mais próximo - como o grande crescimento de redes sociais virtuais disponíveis para smartphones, tablets e computadores cada vez mais avançados. A narrativa, no sentido benjaminiano, retira da experiência o seu próprio fio condutor de uma comunicação que se faz implicada, assegurando a possibilidade de a história ser tocada em frente e não apenas ser esquecida, banalizada.

Numa pesquisa de lente compreensiva, embasada numa perspectiva da fenomenologia existencial, utilizar da narrativa como via de acesso às histórias parece ser uma possibilidade de testemunho e de autenticação do que se conta transmitido de uma experiência. Vários trabalhos (Aun, 2005; Melo, 2015; Santos, 2016) apontam a narrativa como esta possibilidade, experienciada em suas pesquisas, revelando que o pesquisador se torna, ele mesmo, um narrador de sua experiência.

Assim, para Benjamin (2012), "O narrador retira o que ele conta da experiência: de sua própria experiência ou da relatada por outros. E incorpora, por sua vez, as coisas narradas à experiência dos seus ouvintes." (p. 217). Nesta direção, viver este tipo de narrativa aproximanos também do sentido de política, indicando, mais uma vez, que o rigor científico empreendido das ciências "puras", "duras" ou "naturais" não se fez permissivo nesta pesquisa em questão. Este rigor não só põe em questão nossas práticas acadêmicas, como também nos aponta que é preciso afastar-nos de nossa própria pesquisa e de nós mesmos para que algo ali seja informado a quem ler, a quem não experienciou, por este modo, a pesquisa. Embasado nesta perspectiva metafísica de ciência, de um lado, o pesquisador não consegue se implicar na questão (por entender que deve existir uma neutralidade para com seus "eventos") e, de outro, sua escrita se torna distante, parecendo mais uma descrição destes "eventos", informando em vez de contar. 
Perseguindo este sentido, aproximando do pensamento de Walter Benjamin, encontro em Jorge Larrosa uma possibilidade de pensar a experiência e sua consequente comunicação no campo da pesquisa. Para ele, a experiência está interligada à condição do ser humano, implicada pela palavra e pela vida que ela toma: "Quando fazemos coisas com as palavras, do que se trata é de como damos sentido ao que somos e ao que nos acontece" (Larrosa, 2018, p. 17).

Nesta direção, a experiência está marcada pelo modo como as palavras tomam forma e vida, comunicando sobre o que está seguramente interligado ao existir. Assim como o pensamento benjaminiano, este sentido de experiência tematiza a implicação com a ação que decorre, sendo ela testemunhada e autenticada a partir do encontro com a reflexão deste vivido. Diferentemente da informação, que cancelaria nossas possibilidades de compartilhar experiências, estas dizem do "que nos passa, o que nos acontece, o que nos toca" (Larrosa, 2018, p. 18), possibilitando o câmbio de histórias que são vividas e encenadas no espaço público.

A escolha pela narrativa da experiência, neste trabalho, deu-se pela necessidade de olhar para emergência da urgência da comunicação de uma contação. Entendo que, quando utilizada como recurso numa pesquisa, a experiência tem um caráter que se relaciona com a mudança, por entender que ela pode suscitar possibilidades outras de reflexão e ação.

No caso desta pesquisa, passo a compreender que a perspectiva com a qual estou trabalhando tematiza uma dimensão que sinaliza um olhar demarcado também por uma mudança. Se entendemos que as narrativas colhidas podem gerir uma comunicabilidade sobre a experiência de quem conta para outros e outras, podemos inferir que há uma possibilidade de, por meio da implicação com as histórias, compartilhar de uma "mudança social".

Seguindo isto, compreendo que as histórias contadas precisam de uma veracização de um testemunho dado, revelado (Critelli, 1986). Por sua vez, Benjamin (2012) fala que

Contar histórias sempre foi a arte de conta-las de novo, e ela se perde quando as histórias não são mais conservadas. Ela se perde porque ninguém mais fia ou tece enquanto ouve a história. Quanto mais o ouvinte se esquece de si mesmo, mais profundamente se grava nele o que é ouvido (p. 221).

Consonante a isto, Larrosa (2018) aponta que

A palavra experiência vem do latim experiri, provar (experimentar). A experiência é em primeiro lugar um encontro ou uma relação com algo que se experimenta, que se prova.... A palavra experiência tem o ex de exterior, de estrangeiro, de exílio, de estranho e também o ex de 
existência. A experiência é a passagem da existência, a passagem de um ser que não tem essência ou razão ou fundamento, mas que simplesmente 'ex-iste' de uma forma sempre singular, finita, imanente, contingente (pp. 26-27).

Nesta direção, indaga-se o lugar do pesquisador-interventor, pois, na medida em que ele é convocado a ir a campo, ao mundo, é também solicitado que se demarque no outro, esteja ali para. Talvez seja neste trânsito que o termo escuta clínica começa a tomar mais clareza, mais aprofundamento. É embebecido pelo contato com o outro, em meio às suas histórias, que é possível conhecermos sua tradição, seu lugar, sua voz, sua disposição em também estar ali para narrar, para cambiar memórias, trajetórias, experiências.

Assim, a comunicação destas histórias revela que o pensamento de estar solitário cai por terra, pois narrador e ouvinte compartilham da tensão que atravessa a comunicabilidade, e "mesmo quem lê partilha dessa companhia"16 (Benjamin, 2012, p. 230), criando uma teia de sentido pela qual as histórias são transmitidas, assim como se fazia nos primórdios das sociedades.

\subsection{O recurso: historiobiografia}

Alinhado ao que pretendo conduzir na pesquisa, encontro em Critelli (2012) a possibilidade de a narrativa tornar-se permissiva a partir do caminho metodológico que a autora nomeia de "historiobiografia". Para ela, "Seu intuito é compreender para onde e como alguém se dirige em sua vida" (p. 100), indicando que o que para a historiobiografia interessa é a recuperação “da história pessoal através das narrativas nas quais os indivíduos, plurais e singulares, acondicionaram, preservaram, salvaram e projetaram sua existência pessoal e seu destino e na qual escreveram o sentido da vida" (p. 101).

A historiobiografia permite a possibilidade de colocar questões em andamento, inclusive de até mesmo repensar a questão de pesquisa. Esta possibilidade de capturar narrativas delineia toda uma concepção do que entendemos por pesquisa, uma vez que extrapola o campo da unilateralidade, cientificidade e neutralidade, pois, a todo momento, a afetabilidade se faz presente no recolhimento dessas histórias.

\footnotetext{
${ }^{16}$ Durante a última orientação com o grupo de pesquisa no qual faço parte, foi sinalizada a relação que a comunicabilidade de histórias tem com expressões artísticas nordestinas, especialmente com a literatura de cordel. Passo a compreender que as histórias testemunhadas por mim representam também a metáfora do cordel, que, na minha tradição nordestina, reverbera o chamamento ao transeunte, estrangeiro, viajante, que tem contato com histórias penduradas em cordões. A peculiaridade destas histórias encontra-se na destreza paradoxal em estarem ali: sempre penduradas, acessíveis, perambulando, acompanhadas de outras histórias, porém "escondidas" até que alguém as encontre.
} 
É possível que as histórias contadas não somente empreendam uma reflexão para quem narra, ouve ou lê, como também possibilitem a destinação de vários endereçamentos de compreensão, indicando que o que este trabalho demonstrará em sua tessitura reflexiva não se esgota apenas pela minha compreensão dos fenômenos narrados, visto que "a experiência é para cada qual sua, singular e de alguma maneira impossível de ser repetida” (Larrosa, 2018, p. 32).

Para isso, preciso indicar ao(à) leitor(a) a minha questão de pesquisa. O nascedouro dessa questão é fruto não somente da minha experiência como psicólogo e pesquisador, mas como gente. Como apresentado na introdução, o movimento LGBTI, as lutas pela igualdade de gênero, identidade de gênero e diversidade de modos de expressão da sexualidade apontam que há uma necessidade, carência, desalinho de questões na saúde que, muitas vezes, não são comunicadas. Nesse caminhar, questiono: como tem sido a experiência de travestis, mulheres transexuais e homens trans, no que diz respeito às suas corporalidades, e quais experiências de cuidado esta população requer?

\subsection{A via de acesso: entrevistas narrativas e diário de bordo como instrumentos}

Na compreensibilidade da historiobiografia, é preciso haver uma via de acesso no encontro entre narrador-ouvinte, para que seja possível conduzir estas histórias de vida, tornando-as autenticadas. Os instrumentos de pesquisa que utilizei durante o trabalho revelaram-se numa perspectiva de acompanhar o movimento de quem fui ao encontro. Sendo assim, dois instrumentos foram utilizados como via de acesso para recolher estas historiobiografias: a entrevista narrativa (Flick, 2009) e o diário de bordo (Aun, 2005).

Tais instrumentos mostraram-se como possibilidades de entrar em contato com as experiências de travestis, de mulheres transexuais e homens trans e com a metamorfose destes corpos, a fim de convocá-los(as) a narrar suas histórias em torno das experiências circunscritas pelo cotidiano vivido - especialmente no que diz respeito ao modo como compreendem suas corporalidades.

Esse modo de investigar pôde, ainda, possibilitar uma compreensão sobre os modos de habitar o corpo trans, gerando possibilidade de reflexão acerca de práticas de atenção e cuidado de profissionais de saúde, em especial da ação clínica de psicólogos(as) que se destinam a esta população. Esses instrumentos servem também como um modo de o pesquisador entrar em contato com essas experiências que o afetam na tessitura do pesquisar, aclarando um sentido para pensar o objeto de pesquisa e revelar suas implicações no mundo contemporâneo. 
As entrevistas narrativas se mostram como uma alternativa de pesquisa-intervenção (Flick, 2009), pois, à medida que os participantes contam suas histórias, entram em contato com uma possibilidade de refletir sobre as suas vidas. Colocam em voga experiências que os afetam; experiências estas que vão se construindo como uma teia de sentido e que poderão abrir horizontes para desenhar um sentido possível sobre a comunicabilidade de uma ação clínica e política, dialogando com o sentido historiobiográfico.

Ao me referir ao diário de bordo, entendo-o como um convite para o pesquisador refletir e tecer uma compreensão do que foi colhido, deixando-se afetar pelas histórias narradas durante o caminhar-acompanhado das entrevistas narrativas. É também uma forma de o pesquisador assumir um lugar de (re)ver suas compreensões, um momento de se questionar sobre essas experiências e de se encontrar em diversos horizontes de sentido em torno dos fenômenos (des)velados (Aun, 2005).

Assim, de fato, toda a compreensão a partir da analítica empreendida em torno das narrativas, nesta tese, passa a tomar uma tonalidade de diário de bordo, por entender que o sentido construído, decorrente das entrevistas, se volta à comunicabilidade da afetação transcorrida destes encontros.

Como toda escrita, "O diário é realizado, a próprio punho, por um protagonista disposto a compartilhar as marcas dos vestígios da experiência" (Silva \& Santos, 2017, pp. 116-117), demarcando pelo corporar sua própria marca no processo do caminhar. Diferentemente de apenas um instrumento de coleta de dados ou de um diário de campo, a proposta do diário de bordo não é somente colocar as impressões do que se observou no trajeto, mas sim deixar-se marcar pela exposição da imersão no campo, demarcando em palavras a sua compreensão compartilhada. Assim, toda a tese, em si, torna-se um diário de bordo desta imersão experienciada.

Nesta marcação da historiobiografia, na tentativa de apreender uma compreensão sobre que corpo é este que se mostra itinerante e como as experiências de corporalidades de travestis, mulheres transexuais e homens trans são demarcadas no cotidiano, as entrevistas, traduzidas em narrativa, podem permitir a reflexão de um espaço de acolhimento para se compreender a questão provocadora da tese: como tem sido a experiência de travestis, mulheres transexuais e homens trans, no que diz respeito às suas corporalidades, e quais experiências de cuidado esta população requer? 


\subsection{O contato: circunscrição de um campo}

Abrindo a possibilidade destas histórias advindas não somente da própria experiência vivida, mas pensando o campo da saúde, faz-se necessário abrir espaços para estas vozes poderem dizer do dito, não-dito e inter-dito em suas historiobiografias. Tal espaço reflexivo foi pensado a partir da necessidade de espaços de efetivação de políticas públicas e estratégias de acompanhamento de especificidades de cotidianos de LGBTIs, em especial de travestis, mulheres transexuais e homens trans.

Deste modo, a pesquisa focaliza a comunidade $\mathrm{T}$, em razão de sua (in)visibilidade, enfrentamento, (r)ex(s)istência e luta, tendo como orientação esta questão inicial, compreendida como uma bússola (Cabral \& Morato, 2013). Como firmado anteriormente, a saúde tem em vista o processo transexualizador como o principal "carro-chefe" para se voltar às demandas da população $\mathrm{T}$.

Foi neste caminho que, inicialmente, pensei em construir essa tese. De início, tinha a questão "Como psicólogos e psicólogas que lidam com a população trans e travestis compreendem as experiências destas corporalidades no campo da saúde?”, especificamente nos hospitais que fazem cirurgias de redesignação sexual.

Por outro lado, passei a perceber que a questão da pesquisa talvez não traria a dimensão do corpo travesti e do corpo trans com tamanha propriedade. Assim, intentei compreender como estes corpos são compreendidos no campo da saúde - escutando profissionais e a população em específico -, por entender que o "corpo trans" enfrenta uma "problemática” geral no campo da saúde, tal como veremos no terceiro e no quarto capítulos desta tese.

Perseguindo este caminho, passei a compreender, pelo ensejo dessas instituições, que, mais uma vez, a questão pareceu circundar em um lugar que, talvez, não revelasse uma dimensão maior, a saber as especificidades das corporalidades travestis e trans. Assim, como as práticas de cuidado são sempre destinadas para outros e outras, compreendi que seria imprescindível o contato com esses(as) outros e outras. Mais uma vez, então, o campo mostroume outro caminho.

Ademais, abrir espaços para questionar os lugares que a saúde engendra em torno das práticas de cuidado endereçadas a esta população permitiu dialogar com discursos já formulados e reformular outros. Este caminho foi possível por entender que esta pesquisa se destina por um fio condutor do testemunho de narrativas.

Seguindo essa premissa, começo a fiar um sentido possível, encontrando essa tematização como entrelaçada a um caráter político do ato de pesquisar - se entender que ele 
dá espaço para o início de uma ação nova (Arendt, 2018a). Portanto, entrevistei três pessoas, sendo uma travesti, uma mulher transexual e um homem trans, de modo que o sentido possível da questão da pesquisa seja posto, ela mesma, como uma questão.

Importa destacar que transformei a questão-bússola em um pedido aos participantes, indicado como "Fala, para mim, tua experiência de ser uma travesti, mulher transexual, homem trans" - a depender da realidade da pessoa em questão -, por entender que precisaria ter contato com essas experiências narradas para, então, a bússola poder apontar qual caminho seguir, o norteamento.

O modo de contato com estas pessoas deu-se a partir da "Amostra Intencional", que, para Thiollent (1986), trata-se de "um pequeno número de pessoas que são escolhidas intencionalmente em função da relevância que elas apresentam em relação a um determinado assunto" (p. 62), sendo as três pessoas indicadas pelo/as próprio/as entrevistado/as. O tema de tais questões foi conduzido pelos próprios narrador e narradoras. Como critério de inclusão para o andamento da pesquisa, foi adotado, portanto: ser travesti, mulher transexual e homem trans e ter entre 18 e 50 anos. Como critério de exclusão, adotou-se as pessoas que não apresentam tais características.

\subsection{O caminho: da escuta, do testemunho e da autenticação}

Durante a participação na pesquisa, as narrativas foram gravadas em áudio mediante a autorização das(o) participantes e da assinatura do Termo de Consentimento Livre e Esclarecido. Importa ainda destacar que o estudo passou pelo Comitê de Ética em Pesquisa com Seres Humanos do Instituto de Psicologia da Universidade de São Paulo (CEPH-IPUSP) e respeitou a todos os critérios estabelecidos pelo comitê, sendo aprovado e recebendo o número CAAE: 79045917.1.0000.5561.

Após a produção das narrativas do(as) participante(s), foi realizado o processo pormenorizado por Santos (2005), que abarca: 1) transcrição do material colhido (como gravado); 2) literalização deste material (ou seja, a transcrição do áudio em formato de texto compreensivo); 3) autenticação do que foi narrado (em que se devolveu o literatizado ao depoente, e ele pôde modificar ou não o que estava transcrito, de modo que se aproximasse melhor de sua experiência); 4) análise dos depoimentos (quando atribuí um sentido entre o colhido em narrativas e o que se revelou como fenômeno, lançando luz de uma conversação com autores que falam sobre o expresso). 
Esta forma de organização para elaboração da experiência com a pesquisa é apontada, por Silva e Santos (2017), como sendo uma possível demarcação de uma hermenêutica. Assim como o deus Hermes, “o pesquisador se coloca como mensageiro" (p. 19), levando à luz a comunicabilidade para quem cambia narrativa. Entendo que esse é um modo possível de olhar para a historiobiografia, tecendo uma compreensão testemunhada no espaço publicizado. Enfatizo, com isso, que todo o material gravado virá transcrito literal e integralmente nas páginas seguintes, como modo de possibilitar a voz, a vez e o lugar de fala do(as) narrador(as).

Após a transcrição do áudio, foram utilizados outros nomes para o(a)(s) participante(s). Os nomes foram escolhidos pelo(as) próprio(as) narrador(as), por acreditar que nome é a possibilidade de também se firmar a voz e o lugar de existência. Todo o material original (gravações, TCLE e anotações específicas) será arquivado durante um tempo após a pesquisa (5 anos), a fim de resguardar a identidade do(as) e participante(s) (conforme estabelecido no TCLE).

Para a análise das narrativas, este escrito caminhou pela "Analítica do Sentido", proposta por Dulce Critelli (1996), que traz cinco "momentos de desvelamento do real" que se perpassam durante todo o processo da pesquisa, acontecendo simultaneamente: 1) desvelamento - momento de uma primeira afetação em torno da escuta/recolhimento das narrativas; 2) revelação - modo em que se busca um sentido para a afetação do fenômeno que aparece; 3) testemunho - quando se comunica o que foi literatizado pelo(as) narrador(as) entrevistados; 4) veracização - quando o pesquisador dá seu depoimento demarcando sua compreensão, fazendo, ainda, uma "conversa" com autores que transitam pelas temáticas reveladas nas entrevistas; 5) autenticação - momento no qual a pesquisa é levada a conhecimento público.

Após, então, revelar as compreensões metodológicas, compreende-se que, nesse modo de investigação, não há uma neutralidade por parte do pesquisador, como já assuntado anteriormente. Em outras palavras, essa reflexão poderá apontar um compartilhamento de uma abertura para tocar e ser tocado, para que a pesquisa possa desvelar e revelar o sentido da questão norteadora, compreendendo e lançando um olhar para as corporalidades de travestis, mulheres transexuais e homens trans, e refletindo uma possibilidade de ação clínica e política para a psicologia.

O caminho, até o momento, foi desenhado. Os relevos constituíram-se mostrando suas elevações, seus solos, seus ares e suas dimensões. Às vezes, imaginei-me como no deserto, como se estivesse vendo apenas uma miragem, noutras, adentrava-me por entre uma floresta encantada, imerso pela aventura. 
No meio do caminho, alguém quis contar sua história. Senta, porque assim como com as três pessoas que encontrei, há sempre espaço para empreender um novo sentido. Se quiseres, para um pouco. Elas e ele também pararam por entre as sombras, quando os calos estavam latejantes pelos caminhos trilhados. Essas três pessoas têm existência marcadas. Elas três têm nome: Fernanda, Joyce e Eduardo.

Nessa rua tem um bosque ${ }^{17}$. E eu não estou mais só.

${ }^{17}$ Referência à cantiga popular "Se essa rua fosse minha", de autoria de Mário Lago e Roberto Martins. 


\section{3 “QUERO LANÇAR UM GRITO DESUMANO, QUE É UMA MANEIRA DE SER ESCUTADO": (des)encontros com corporalidades}

\section{1 "De muito usada a faca já não corta": o corpo-dobra de Fernanda na solidão da cozinha}

Marquei o encontro com Fernanda em sua residência. $\mathrm{O}$ encontro foi regado por café e carinho de seu cachorro, que sempre subia no meu colo. Sua casa, com o cheiro de café emanando pelos cômodos, tornava-se, a cada momento, um lugar acolhedor. Isto porque me ocorre, agora, que nossa casa, lugar em que moramos, muitas vezes, não nos acolhe, apenas nos abriga. Ali, o sentido de casa soava-me como um lar para Fernanda. Podia vê-la em cada móvel, em cada detalhe, em cada copo que jazia na pia ou nos armários, bem como no café: forte, porém meio adocicado.

Ela me convidou a sentar. Brincando com o seu cachorro, conversávamos sobre as burocracias de uma pesquisa e de como a proposta da minha seria de uma conversa que fosse leve e fluida. Pedi para que, caso ela se sentisse desconfortável, avisasse e disse-lhe que não precisaria falar sobre determinados assuntos que julgasse inconvenientes. Disse, ainda, que, caso estivesse cansada, também não precisaria se forçar a conversar comigo. Ela me respondeu que não se incomodava, pois nossa história precisa ser comunicada e narrada e, como vai falar adiante, ela é “de ir e vir". Indo e vindo, viajante que sou, questiono como é "ir e vir" pela história de alguém e, a partir deste momento, foi o modo possível para me aproximar de Fernanda, e sua história não poderia ser contada de outro jeito.

No momento em que conversávamos, lembrei-me de um filme chamado Martha Marcy May Marlene, que traz a seguinte narrativa: "Eu dividi tudo em pequenas partes... E tentei ver cada pessoa como um número em uma equação gigante. Mas não deu certo. Porque as pessoas não são como números. São mais como letras. E essas letras querem se tornar histórias. E o papai dizia que as histórias precisam ser compartilhadas.”.

“As pessoas não são números.". Escutei esta frase, na mesma semana, de um cliente no consultório. Fiquei refletindo durante um grande tempo e comecei a olhar para minha pesquisa. Todo o tempo que passei até chegar aqui, neste momento de escrita; todo o tempo que passei pensando sobre um caminho que desse corpo ao que queria; todo o tempo que perdi em escrever, mas que ganhei - e muito - em poder dar sentido às ideias, transformando-as em palavras (mesmo que ficassem somente "no plano das sombras"); enfim, em meio a esse tempo, eu vi minha pesquisa como uma equação gigante na qual eu teria que colocar meus números e poderia usar de artimanhas que me dessem um denominador. 
Entretanto, minha pesquisa é com pessoas, para pessoas. Elas "são mais como letras". Procurar por um denominador comum seria dar indícios de que um mais um seria igual a dois. Só quem poderia nominar suas histórias seriam pessoas e somente elas poderiam dizer se um mais um seria igual a dois, ou três, ou mil. Somente elas poderiam dizer do quanto foram palavras, do quanto se tornaram histórias e do quanto puderam compartilhá-las. Elas também poderiam dizer-me quando se sentiram como números, como esta equação gigante que o caos de nossos tempos pede. Mas, de certo modo, algo começava a habitar em mim: a pesquisa já não era somente uma pesquisa, mas a possibilidade de uma história ser contada por mim, pelos colaboradores da pesquisa, dando-nos voz para ir ao mundo.

Fernanda não era número. Fernanda não era só palavra. Fernanda também era café. Fui embebecido por ela, queimando por dentro, arrepiando meu corpo - do mais íntimo das entranhas até a pele que tocava a xícara. Eu, que até a adolescência colocava água gelada no café para deixá-lo morno, consigo hoje tomá-lo amargo e quente.

Fernanda não perguntou como eu queria o café. Serviu-me quente, forte e adocicado. Entendi que ali era seu mundo e que, para conhecê-lo, teria que adentrar a seu modo. Na minha frente, estava ela, com um olhar curioso e com sua história para contar.

Senta um pouco. Escolhe teu café. Se possível for, adocica-o. O que virá precisa disso.

Pesquisador - Eu gostaria que você falasse um pouco sobre sua experiência de ser uma mulher transexual.

Fernanda - No meu caso, que morava no interior da Paraíba, a gente não tem referência. É um assunto que a gente não sabe. Então, assim, você não sabe nem o que é trans, né? Não tem como saber de imediato o que você é. Mas desde a mais tenra idade, desde muito tempo que eu percebo que não era como as outras crianças, sabe? Por exemplo: eu nunca ficava de cueca, como as outras crianças, porque eu tinha vergonha de ficar, porque pra mim tinha que ser uma calcinha e não ter nenhum volume ali, né!? Só que eu não sabia dar nome a isso. Eu percebia isso, só que eu não percebia o porquê. Na adolescência, também, os meninos ficavam sem camiseta e eu não ficava, porque eu tinha vergonha e eu não entendia o porquê e não conseguia entender. Na graduação, quando fiz, eu não tinha transicionado. Aí, no mestrado, foi quando comecei a tomar hormônio, porque quando eu estava fazendo mestrado, eu vim fazer uma pesquisa aqui em São Paulo, na 
USP, no IEB ${ }^{18}$, e eu comecei a ver a quantidade de travesti que tinha aqui em São Paulo. Aí comecei a entender que eu era como elas, né!? Porque lá em Campina Grande não tinha referência... Então, aí... Foi em minha primeira relação sexual, que conheci um menino e a gente foi transar e eu fiquei... eu tinha o quê? (pausa) Eu já tinha vinte e poucos anos! E eu fiquei extremamente constrangida. Eu não conseguia transar. Eu estava usando uma camisa de mangas, segunda pele. Por que eu não conseguia tirar? Porque eu não tinha seios. Então assim... foi horrível a primeira vez que eu transei. Eu não queria transar na condição de gay. Porque se eu não tinha transicionado, se eu não era mulher, quem se aproximava de mim? Homens casados, que diziam assim "Eu como viado!" ou gays. E eu não queria um homem gay, porque eu não me sentia... não conseguia dar nome a isso... Porque eu não tinha referência. Mesmo lendo tudo que eu já lia, mas nenhuma leitura era voltada pra isso. Aí eu comecei a entrar nos Estudos Culturais, comecei a ler Guacira, e ela começou a falar disso de performance de gênero... Aí uma professora minha foi e disse assim: "Talvez você não seja homem, talvez seja uma mulher!", e eu não entendi o que ela queria dizer. E ela não me disse também. Aqui, em São Paulo, eu vendo outras referências... eu vi esse baque que eu tive - da minha primeira vez ter sido horrível porque eu não queria ser tratada como um menino, sabe!? Aí eu voltei pra Campina Grande, conversei com meu sobrinho Pedro, que é gay, e ele disse "Mulher, tu não é gay, tu é trans.". Aí ele falou da Lea T. Aí comecei a assistir coisas sobre, pra eu me entender. Comecei a me compreender. Comecei a ver como era o uso do hormônio, tudo sem consultar médico, sem nada! Procurava em blog de internet, tutorial, comecei a adicionar um monte de blogs, de grupo e comecei a ver o que era e comecei a tomar hormônio por conta própria... Há seis anos eu comecei a pensar na transição e nessa época era impossível isso. E é comum as pessoas tomarem por conta própria porque é uma dificuldade. Aí quando eu vim pra São Paulo, que eu decidi transicionar mesmo, pensar no silicone, em todo esse processo. Quando eu cheguei aqui, fiquei sabendo do CRT e fui pra lá, fazer a matrícula. Demorou muito tempo! Pra pegar hormônio demoraria seis meses pra isso acontecer, porque a quantidade de consultas e de exames... Tudo isso pode ser feito em uma semana, não precisa dessa demora toda! Só que eu pressionei a médica que me atendeu, que fez o acolhimento, ela era clínica, e eu falei pra ela: "É melhor me receitar, porque não vai adiantar de nada! Eu vou lá na Rua Aurora e eu vou comprar hormônio e vou tomar. A única coisa que você está fazendo é me fazer gastar ou fazer

\footnotetext{
${ }^{18}$ Instituto de Estudos Brasileiros da Universidade de São Paulo.
} 
com que eu me prostitua, porque eu vou pra esquina atrás de dinheiro pra tomar hormônio. Aí, você vai me colocar numa situação de risco maior que me dar o remédio, porque, se você me der o remédio, eu vou tomar, e, se você não me der, vou ter que procurar outros caminhos, mas não vou deixar de tomar.” Aí ela me deu. E hormônios são à base de anticoncepcional. É como Tilenol, você quer, você compra... No caso de hormônios de trans femininas é fácil, agora no caso de trans masculinos eu não conheço tanto, mas acho que não é a mesma coisa. Em linhas gerais, é isso. Mas isso aí (pausa) tem todo um sofrimento né!? No meu caso, foi um sofrimento imenso quando eu descobri que era trans, porque também a referência que eu tinha eram as meninas de São Paulo. Só que, na época, eu achava horrível! Porque a minha cabeça também estava imbuída de preconceito. Eu dizia assim: “Eu não quero ser como elas! Eu não sou esses monstros!”, eu achava horrível! E eu usava esses termos mesmo. Eu sofri muito, porque eu não queria ser daquele jeito... O corpo... eu não queria ter aquele corpo. Eu não queria estar naquela situação, na rua. Eu não queria ter aquela linguagem. Eu não queria ser elas, no contexto geral que elas foram construídas, naquele contexto ali. Eu não queria ser. E tudo que eu via me levava pra esse lugar, porque, quando você transiciona, tudo se fecha! Mesmo você com graduação, com mestrado... sem nome retificado, sem nada, é um caminho muito difícil. Só que o que é curioso... bom, eu trabalho com esquizoanálise, minha fala não é linear, sempre vou e volto... Se você ver minha infância, por exemplo, eu não sabia o que era. Sempre eu gostava de menino. Eu me apaixonava. Ficava pensando, sempre me colocando no lugar da menina. Não sei se com gays isso acontece, mas eu sempre me colocava no lugar da menina. Meu lugar era o da menina! Eu sofria muito na escola, porque meus traços naturais são bem finos e sempre foi ligado ao feminino... então era muito, muito sofrimento... Eu nunca tive pelos, barba... ter que fazer laser no rosto... nunca tive. Era uma androginia já, natural. Então, assim, eu sofria. Os meninos... eu não conseguia apresentar trabalho na escola, porque eu já sabia: quando eu ia lá pra frente, eles ficavam: "Engrossa a voz!'”. Toda hora, eles ficavam mandando eu engrossar a voz. Isso era bem difícil! A vida toda isso! Isso a vida toda. E eu sempre me colocava ali. Então, assim, quando eu entrei na graduação, ficou mais fácil porque eu tinha um saber... ali eu construí um saber. De algum modo, as pessoas tinham uma admiração, ou raiva, ou inveja, seja lá qual sentimento, porque eu era referência no campo da teoria e metodologia na graduação e no mestrado. Então, eu desenvolvi também uma postura muito reativa, acho que muito por conta disso. Porque sempre quando eu quis falar de forma natural isso eu me analisando, né?! Eu não sei -, porque eu não conseguia falar! Nunca conseguia 
falar, porque eu era tratada desse jeito, entendeu? Então, não era um elogio, dizer assim: “Menino, engrossa a voz!", porque eles estavam falando de modo pejorativo e não de modo afirmativo, como elogio. Era isso. Era a mesma história que tem por aí com muitas transexuais e travestis. Então, foi bem difícil. Só concluí o ensino fundamental e o ensino médio porque meus primos me defendiam, porque minha mãe dizia que eu tinha que estudar, porque eu nem queria estudar, não queria ir mais pra escola! E eu era uma criança pequena, inteligente, não tinha tanta dificuldade em aprendizagem. No ensino fundamental, um monte de menino me pegou, se juntou e quiseram tirar minha roupa, foi horrível! Horrível, horrível, horrível!!! Aí, eu não queria usar o banheiro mais, e não tinha isso de banheiro com questão de gênero, isso não era discutido. Tipo, há vinte e cinco anos atrás, quem era que discutia sobre trans? Ninguém ia falar sobre isso, né!? Enfim... se a gente olhar o contexto político, não é tão bom, mas também não é tão horrível como era, porque não existia essa possibilidade. Olha só a que exposição uma criança pode ser posta! Eu acho que São Paulo é referência pra o mundo. Pra o país, pra o mundo! Acho que o Programa Transcidadania, que foi lançado em dois mil e quinze, ele também tem... também é efeito dele, desse programa. Ninguém discutia. A Globo nunca falou sobre isso. Entendeu? Quando foi lançado o Programa Transcidadania, o Fantástico foi ver o que era, enfim... Acho que o Programa, de certa forma, o Transcidadania pressiona um pouco as pessoas pensarem sobre isso. Acho que ajudou. Lógico que a literatura, na área pedagógica... se você vê a galera do Rio Grande do Sul, já está discutindo isso há dez anos, de forma mais tranquila, não é tão explícita essa discussão. Eles discutem isso muito dentro da Pedagogia, da História, mas não assim: Vou falar sobre transexualidade, vem como um tema de forma transversal. Mas já vem sendo discutido tem mais de dez anos, mas pra chegar aqui é uma série de fatores. Embora o momento político seja horrendo, que a gente não consegue falar sobre um monte de coisa, mas só que acho que esses focos de luz que vão surgindo, como o Programa Transcidadania, acho que pressiona e abre essa possibilidade. Imagina, quer queira, quer não, uma novela como essa que discute transexualidade - de forma superficial, da forma como for, críticas à parte -, mas isso aí possibilita... por exemplo, à minha mãe, poderia possibilitar a ela de ser debatido. Ela nem sabia o que era! Quando eu cheguei pra ela, em dois mil e doze, dois mil e treze, que eu disse assim: "Mãe, eu não sou um menino. Eu sou uma menina.". Ela disse assim: “Como assim? Você quer dizer que você é gay?”, aí eu disse: "Não! Não sou gay! É esse o problema. Não sou gay.”. E ela queria morrer! Ela disse assim: “Tudo, menos isso! Imagina você se vestir de mulher!". Esse assunto era cem por cento cru. Eu não estou 
dizendo que uma novela como essa, que um Programa como o Transcidadania pode ter o poder - e pode ter - de desconstruir a cabeça da minha mãe, por exemplo, mas seria referência pra ela, em algum momento pra ela, nem que seja um minuto, pensar um pouco sobre isso. E não foi possível, porque não tinha nada! Não tinha nem pra mim, imagina pra ela, né!? Então, assim... foi bem difícil! Minha transição não é antiga. Minha transição tem cinco anos. Começou há cinco anos a minha transição. Comecei a tomar hormônio em dois mil e doze, e em dois mil e treze eu vim pra São Paulo. A dosagem que eu tomo é baixa. Eu sempre tomei, por exemplo, eu sempre tomava duas injeções de progesterona por mês, e basicamente é essa dose que a médica passa. Então, é a mesma dose. Eu não vi diferença, mesmo tomando de forma errada, sem prescrição médica, eu estava fazendo mais ou menos certa a dosagem. Aí, quando eu fiz os exames pra saber a quantidade de feminino e de masculino que eu tinha no corpo, ela viu que eu precisava só de uma quantidade baixa, porque a quantidade de hormônio que eu tive não me fez ter pomo de adão, não me fez ter pelo, porque não era tão alto o masculino. Então, pra mim, ela prescreve pouco, entendeu? Algumas meninas que precisam de mais hormônio, pra bloquear o masculino, elas não gostam com acompanhamento, porque, geralmente, não dá o efeito. Mas tem outras meninas, que é o meu caso, que essa quantidade é ideal, porque, naturalmente, a quantidade de hormônio masculino não é alta. Porém, querer mais implica em efeitos colaterais, porque mais hormônio pra o corpo dá os efeitos colaterais. A pessoa fica entre a cruz e a caldeirinha. Se eu tomar mais, vou ficar feminina, mas vou trazer uma série de efeitos colaterais pra o meu corpo, AVC... Tem uma mulher transexual que ela trabalhava comigo e teve um AVC, em dois mil e dezesseis, ano passado. Eu não sei. Acredito que ela tenha feito uso de uma dosagem bem alta, porque ela teve esse AVC e as meninas que a conheciam disseram que ela tomava muito hormônio. É tanto que ela era muito inchada, porque o hormônio incha. Quando ela teve o AVC, esse ano mesmo, quando a gente estava trabalhando junta - é pra pôr isso na tua tese -, quando tinha travesti e mulher transexual, na Prefeitura de São Paulo, trabalhando, que depois que o Haddad perdeu e o Dória entrou e mudou todos esses projetos e o formato dos Centros de Cidadania e a contratação de travesti e mulher transexual caiu. Porque era só o que existia: travesti e mulher transexual contratadas nos postos e trabalhando muito bem, enfim... quando era possível isso, de a gente se encontrar enquanto grupo, porque não existe mais, ela me deu um monte de hormônio: "Mulher, toma pra tu, que eu não vou tomar mais.". Tinha muito e eu não tomei. Tinha umas seis Perlutan, que é progesterona, tinha progesterona em comprimido, que até hoje tenho aí, que não tomo... Peguei por educação, 
entendeu? Acho que ela estava fazendo, utilizando muito hormônio, entendeu? Porque fica naquela coisa, no ideal da passabilidade, de ser feminina. Lógico! Eu não poso falar por todas, mas assim, as pessoas que são trans, elas falam que querem a passabilidade. Por quê? Porque, se você tem a passabilidade, você vai sofrer menos. Se você tem a passabilidade, você vai ser reconhecida como mulher. Então, assim... Às vezes, põe a própria vida em risco! O silicone industrial... Você está pondo a vida em risco e mesmo assim você faz! Então... o meu processo foi o contrário. Eu coloquei meus seios (toca nos seios) em dois mil e treze. Foi bem rápido. Cheguei em São Paulo em junho e, em setembro, eu já pus minhas próteses. Eu não queria colocar silicone industrial de jeito nenhum. Não queria, não queria, não queria! Porque elas ficavam mentindo, elas colocavam mais caro e ficavam dizendo assim: as bombadeiras que são as profissionais que injetam silicone líquido no corpo das travestis e mulheres transexuais, em homens trans, se quiserem, em todo mundo! Quem chegar lá e pedir pra injetar. Só que é mais recorrente com as travestis e mulheres transexuais. Mulher cis também procura bombadeira, porque é mais barato e de fácil acesso. (pausa) Aí, eu não queria colocar de jeito nenhum. Aí, ela disse assim, a bombadeira: "Mulher, eu coloco um produto que não é silicone industrial, é Metacril. ”. Eu sabia que não era, mas eu fingi. Pra mim, eu peguei essa mentira e transformei em outra coisa, como se fosse uma verdade, mas não é Metacril que tem no meu corpo. Eu não sou burra! Aí, ela colocou o silicone em mim. Em dois mil e treze, acho que foi em (pausa)... novembro... acho que foi um mês e meio depois, eu coloquei dois litros de silicone. Coloquei. E eu não queria aquele corpo do jeito que ficou. Ficou um corpo super natural e eu não quis. $\mathrm{O}$ meu ideal, acho que por eu assistir desenho animado, tipo Betty Boop, eu queria um CORPÃO daqueles assim (faz gestos pra identificar um corpo com cintura e quadris largos), daqueles da Disney. Aí, eu fui e quis mais. Essa foi minha história. Aí, eu fui atrás da bombadeira de novo e disse: "Mulher, quero de novo.". Aí, entreguei mil reais pra ela, pra ela colocar mais dois litros e ela sumiu com meu dinheiro. Aí, fui atrás de outra e ela colocou. E eis aqui esse corpo! Elas preferem que não tomem hormônio, porque a pele masculina... a pele e o corpo masculino... ele (pausa) é mais... ele não é tão sensível como o corpo feminino. Então, se você não toma hormônio, é muito mais fácil de bombar, porque você não sente dor. Se você toma hormônio, seu corpo muda. Então, todo o seu corpo vai trabalhar como um corpo de uma mulher cis; embora esses hormônios que você bota ali sejam sintéticos, eles trabalham dessa forma, então seu corpo vai ser mais sensível, entendeu? No meu caso, ela... tem uma agulha que é imensa, que é uma agulha... se chama "agulha para cavalo", 
que é uma agulha que ela é bem larga (faz gestos com a mão), que é uma agulha pra passar o silicone, porque, se você colocar numa agulha pra humano, não vai passar o silicone naquela agulha. A agulha é muito grossa. Acho que ela tem a espessura de um dedo (mostra com o dedo), o furo, pra passar o silicone líquido. Todo meu material foi descartável, comprei tudo com ela. Tive esse cuidado! Eu sempre sabia... No meu caso, tinha o conhecimento do que eu estava fazendo e sabia que era importante aquilo e fiz todo um trabalho de redução de danos: "Já que estou fazendo isso, então vou fazer assim: vamos comprar todo o material!". Então, fui com ela, comprei todo o material descartável, essa agulha que é de cavalo, ela fez tudo descartável. Porém, outras meninas, ela reutiliza essa agulha de cavalo, que é uns vinte reais. Vinte reais! Gente... é só comprar, né!? E elas reutilizam, elas fervem na água quente assim e deixam acho que meia hora fervendo pra matar vírus, bactérias e tal. Através dessa agulha, ela pega o silicone líquido, ela marca teu corpo. O meu corpo, no caso, ela marcou todos os pontos, tipo, sete pontos onde o silicone iria entrar... Nas extremidades, pra dar um formato. A minha bombadeira utilizou anestesia. Anestesia de cavalo também. Não é anestesia de humano. É mais fácil comprar, o efeito é mais forte até! É local, sabe!? Então, assim, no meu caso, doeu muito, mas não doeu tanto como as meninas que se bombavam, que ainda se bombam, que se bombavam há dez anos atrás... que não tinha... Era feito no cru, assim (dá socos na mão), sem nada! Você aguentava aquele líquido entrando no seu corpo. Então, ela bombou com essa agulha, teve todo o cuidado, a gente comprou tudo descartável, os recipientes, tudo e numa cama. Ela forrou o lençol, limpo, e me colocou lá e fez. Não tem maca, não tem nada. É tudo precário, porém é a única forma de se construir o corpo que se quer. De uma maneira mais rápida! Aí, ela foi! Bombei uma vez, a segunda, terceira vez. Eu bombei três vezes, porque eu não queria bombar de uma única só vez e colocar, tipo, cinco litros! Porque eu não sabia como iria ficar! Eu preferia colocar dois e dois pra ver como ia ficando o corpo. Aí, ia colocando. No meu caso, doeu mais, muito. E me arrisquei mais, porque, toda vez que você vai bombar, a pessoa pode atingir uma veia sua e, se entrar silicone na sua corrente sanguínea, você morre na hora! Na hora! Não tem chance! Não tem nem como prestar um socorro pra você! Entendeu? (pausa) Uma vai passando pra outra o conhecimento. Geralmente é travesti e mulher transexual, as bombadeiras. Eu não conheço nenhuma mulher cis que seja bombadeira. Deve existir, mas eu não conheço. Essa prática, pelo menos aqui no centro de São Paulo, é bem, bem nossa! Mulheres cis que trabalham com prostituição também, que têm que ter o corpo perfeito, elas também procuram bombadeira. Não com a frequência da travesti, porque a 
travesti, realmente, é uma readequação do corpo. A mulher cis é outra coisa: ela quer dar mais forma, ficar mais bonita. Não que a trans também não tenha isso em mente, mas é outra coisa você querer readequar seu corpo do que só estético. E, assim, os estudos sobre como tratar esse silicone... esse silicone, quando entra no seu corpo, ele se espalha nos seus músculos, principalmente quem vai bombar. A minha bombadeira bombou mais entre pele e gordura, ela não entra pra chegar no músculo, esse silicone. Mas não quer dizer que ele não possa se espalhar e chegar até o músculo. Ela tinha esse cuidado, entendeu? Então, as pessoas que ela bomba... Tem pessoas que ela bombou e tem mais de vinte anos que tem silicone e não teve problema. Mas, entre as meninas que bombam, quando tem problema com silicone, geralmente é no pé, porque desceu. Não fez aquele repouso. Porque o silicone, ele é líquido e ele precisa entrar no estado mais consistente, tem que virar como se fosse uma gordura. Então, se você não faz o repouso de, no mínimo, oito dias, ele pode descer pra os seus pés. Quem trabalha com prostituição e casa de cafetina não tem esse tempo pra ter esse repouso, então o silicone vai descer. Se ele desce, tem muitos problemas. Também, se ele não desce, você pode ter problemas. Você pode ter, sei lá, um abscesso na perna, no quadril. Já aconteceu! Eu, trabalhando numa pesquisa, eu entrevistei uma pessoa que ela teve problema com silicone... só separando o tempo, né!? Isso tem vinte anos, vinte cinco anos, trinta, mais ou menos isso, que ela usou e teve problema. Ela teve problema tem bem uns trinta anos, que ela é uma mulher transexual de seus sessenta anos de idade. Ela é da década de sessenta, setenta... então, na década de noventa, ela teve problema com silicone. E foi horrível, porque, na década de noventa, se hoje os recursos são escassos, imagina na década de noventa! Ela foi pra o Emílio Ribas e de lá mandaram ela pras Clínicas. Amputaram os dois quadris dela, as coxas dela. O corpo dela é todo deformado. Uma coisa horrorosa! Além de fazerem isso com ela, teve a forma que foi tratada: "Vou arrancar suas pernas! Por que vocêfoi enfiar essa porcaria no seu corpo?”. Sabe? Existem absurdos hoje, mas, naquela época, eles não tinham nenhum constrangimento de fazer isso, porque não tinha aparelhos de Estado que punissem, que vigiassem, entendeu? Então, assim, eles falavam isso... Não que não falem hoje em dia. É quem falavam dessa forma. É isso... ela estava com o corpo deformado. Hoje em dia, as meninas elas não vão nem no hospital! Porque o saber que se constrói, dentro do grupo, é maior do que o externo. Médico, enfermeira pode ter esse saber acadêmico, mas elas invadem até o saber acadêmico. Elas tomam até Decadron quando o silicone está inflamado. Tu acredita? Por conta própria! O pé está inchado. Uma amiga minha estava com uma coxa... Eu nunca tive problema com silicone, graças a Deus! 
Ela estava com a coxa, um abscesso assim, inchado, vermelho, parecia que ia explodir. Ela disse: "O que eu faço, mulher, da minha vida?". Eu disse: "Mulher, as meninas tomam Decadron.", e tem outro remédio que não lembro agora. E Decadron é antialérgico, né?! Então, eu penso o quê? (pausa) Como isso é um corpo estranho, não é do nosso corpo, não é nossa gordura, pode ser que seja uma alergia e, na medida que toma o Decadron, faz esse efeito nessa alergia e a perna volta ao normal. Desinchou, fica normal. Aí, às vezes, vai pra o médico e ele fala esse tipo de coisa. Nos tempos de hoje, eles falam esse tipo de coisa: "Ai... olha só... por que você aplicou isso? Vou ter que amputar sua perna." . Não fazem nenhum exame. Só de olhar eles já falam isso. Mas isso é transfobia! A gente já sabe, né!? Não examina essa perna! Não examina, não faz uma radiografia, ultrassonografia, não faz nada! E já fala assim: “Ai, vou amputar essa perna.". Já pra assustar mesmo. Então, as meninas, pra não passarem por isso, muitas nem vão. Como Santa Casa, como CRT. No CRT, tem o Ambulatório TT. É o lugar que é especializado pra isso, e lá dentro elas são destratadas! Então, assim, é muito complicado e complexo. Não estão preparados pra nada!!! Porque, se chega a travesti, é logo HIV! "Vamos fazer HIV, vamos fazer Sífilis.”. Ela tem um silicone no corpo. Que tal analisar como está o coração, como está o pulmão? Porque esse silicone está correndo no corpo dessa pessoa! Essa pessoa pode ter essas complicações cardíacas e circulares, não pode? As maiores complicações são vasculares, porque o silicone... Tem veia que estoura. Então, assim: é preconceito! Já vem a questão da... A gente sabe que a prevalência de HIV, sífilis e ISTs em travestis e trans é altíssima! Até pela única profissão que é permitida e possível delas atuarem, né? Que é a prostituição. A vulnerabilidade chega a ser maior! Mas não é a única coisa que existe! Eles já pedem esse tipo de exame, sendo que tem outras questões que eles não observam. Isso é uma questão importante, essa questão vascular, sabe!? O silicone industrial atrapalha totalmente a questão vascular. Além de não existir conhecimento sobre silicone industrial, tem essa falta de preparo mesmo no trato humano... tudo! No nosso país, se você for LGBTI, você nem pode doar sangue! Começa por aí. Então, assim, não tem muito o que falar e se desdobrar sobre isso. Você não pode doar sangue, como se você fosse soropositivo em potencial, que você tem sífilis, que você tem tudo! Que você é uma bomba! Então, você não pode doar sangue. Por exemplo, eu sou uma mulher transexual e meu marido é um homem cis hétero e ele doa sangue. Por quê? Ele doa sangue porque ele nunca chegou lá e disse assim: "Sou casado com uma mulher transexual.". Por isso que ele doa sangue. Entendeu? Se eu chegar lá, por conta da passabilidade, tá aqui meu documento com meu nome retificado, 
eles autorizam doar sangue. Mas, se eu disser que sou uma mulher transexual, você acha que eles vão coletar sangue? Lógico que não! Eu tenho como grande referência o Programa Transcidadania, que foi o programa que atuei enquanto profissional. Parece que, quando eu falo nisso, eu fico até constrangida, é como se eu tivesse: "Nossa, foi tão ótimo o programa que trabalhei.". Mas não é isso, é que realmente ele... Deleuze chama de "acontecimento" para algumas coisas, tipo, a gente não lida com ideias de grandes fatos históricos, mas com acontecimentos históricos. Isso é um acontecimento. Um acontecimento é aquilo que tem desdobramentos nas vidas das pessoas. Isso é acontecimento numa perspectiva deleuziana. Um acontecimento seria o quê? Quando a Dilma caiu, entendeu? É um acontecimento histórico porque teve o impeachment... Os desdobramentos eram travesti e transexual em museus, pegando ônibus para ir pra escola. A gente via esse sangue pulsando, porque elas tinham vontade. Tinha uma equipe multidisciplinar que era vasta, grande. Tinha esse suporte pra fazer atendimento, retificar nome, pra encaminhar pra hormonioterapia, pra encaminhar pra o CRT. A nossa coordenação ligava pra o CRT. Hoje em dia, a gente não consegue isso. Fazia as articulações. Teve uma vez que a gente estava numa reunião e uma menina chegou me procurando, porque algumas tinham muita empatia e me procuravam quando a coisa era muito íntima. Quando eu cheguei, ela disse: "Fernanda, eu faltei durante duas semanas porque eu tive um problema.". E a ficha dela ia assim, com três dias de faltas, que era o máximo que a gente poderia mandar pra Secretaria de Trabalho. Quando eu entrei na sala de atendimento, que ela levantou a perna da calça, eu saí correndo, sem mentira alguma. Eu disse: “Licença!” e não aguentei. Eu chorei tanto, mas tanto! A perna dela parecia um sofá, um pezão, assim... Não era mais humano aquilo, sabe? E a perna da calça larga, pra cobrir aquilo. Nossa, eu chorei tanto, tanto! Mas voltei, né!? Então, assim, tinha uma equipe pra tratar isso. As pessoas eram vistas na sua construção humana, na sua construção de formação educacional e não enquanto presença de ter que ficar nos espaços. A gente percebe que o Programa Transcidadania está precário, acabando, se arrastando. Então, assim, essas meninas, a autoestima delas subia. Porque imagina desse jeito: sua autoestima lá embaixo e tem uma equipe que lhe dá suporte... Você consegue ligar pra o coordenador de políticas para LGBTI, pra ele acionar Secretaria de Saúde. Todo um cuidado compartilhado! Então, essa menina foi e tal e conseguiu tratar. Até cirurgia foi agendada pra ela duas vezes, mas ela não quis fazer porque tinha... Você pode ter problemas pra fazer cirurgia de retirada de silicone. Ela ia fazer uma raspagem dos músculos das pernas. Mas o que quero dizer com tudo isso? Quero dizer que as pessoas 
eram vistas de outra forma e, por elas serem vistas de outra forma, elas estavam por aí circulando... A autoestima das pessoas sobe! Mas as pessoas estão sendo tratadas do jeito que estão sendo tratadas. Na Praça da República, há três semanas, as meninas foram presas por estarem na Praça da República. Quando eu estou entrevistando na Pesquisa TransNacional, mulheres que têm mais de sessenta anos dizem que, na década de oitenta, isso acontecia, crime de vadiagem. Então, é como se os tempos tivessem atravessando e é como se a gente não estivesse mais em dois mil e dezessete, é como se a gente estivesse em mil novecentos e oitenta! Porque qual a justificativa de prender quem está na Praça da República? Vadiagem! Por quê? Porque prostituição, no Brasil, não é crime. Entendeu? É crime manter casas de prostituição. Então, tiraram elas. Foi travesti e transexual de menor de idade algemada; circularam vídeos na Internet, no WhatsApp... Então, assim, essa é a fotografia atual do que está acontecendo com a população trans em São Paulo. Porque você vê que São Paulo foi cidade modelo. Ganhou aquele coisa de cidade modelo, Rainbow, Cidade Arco-íris. Então, São Paulo estava sendo referência para o mundo nas questões LGBTI. Atualmente, é VERGONHA para o mundo! Porque você prender pessoas por elas serem travestis, só por isso! Porque se for pessoas... As pessoas cis que estavam na praça não foram presas. $\mathrm{O}$ único motivo é porque elas eram travestis e estavam na Praça da República. Tudo isso que a polícia fez, ela fez com o apoio de quem? Ela fez com o apoio da Secretaria de Direitos Humanos, ela fez com o apoio de todas as secretarias, fez com o apoio do gabinete do prefeito e do prefeito. Porque, se a polícia tem a liberdade de fazer isso, é porque o prefeito está dando joinha, está dando um “curtir”. Então, tem um desdobramento aí, não tem? Se o Centro de Cidadania, que é um acontecimento histórico na cidade de São Paulo, onde, incialmente, quando as meninas iam pegar o ônibus "Shopping Plaza Sul" pra o Cambuci, que inicialmente eram chamadas de "traveco" pelos cobradores e motorista... E que elas alteram toda essa questão no enfrentamento diário... E que agora se você vai pra o Cambuci e diz: " $A h$, quero ir pra o Cambuci. É esse ônibus aqui??", aí ele diz: “É a escola das meninas?", porque elas alteraram a cidade, entendeu? A gente está vendo que não está desse jeito mais! As meninas que chegam pra falar à gente, elas chegam: "Nossa, tá uó! Tá uó! Tá uó!’, porque os recursos de linguagem que a maioria tem também são recursos de linguagem frágeis, né!? Mas quando elas dizem que "tá uó", é que a coisa está horrorosa, porque elas sabem que elas não têm valor, que elas não têm espaço, que é uma farsa as atividades que elas frequentam no programa, que não serve pra nada! Os profissionais também sabem que aquilo não serve pra nada, mas a gente finge porque a gente tem que 
trabalhar e as coisas têm que caminhar, e então, assim, existe esse desdobramento de uma gestão pra outra. As coisas estão andando de ladeira a baixo. Um acontecimento histórico na vida de uma pessoa trans seria a elevação da escolaridade, a retificação do registro civil. Mas isso, o acontecimento, quem tem que dizer é a pessoa, se foi um acontecimento pra ela. Porque pode ser que, pra pessoa, não seja um acontecimento. Um acontecimento na minha vida foi ser contratada pra trabalhar no Programa Transcidadania! Foi o primeiro grande reconhecimento, enquanto profissional. Pra mim, isso foi um acontecimento. Isso é um acontecimento... é a dobra... é uma dobra que gera outras dobras na vida, entendeu? Porque, a partir daí, eu saí da condição que eu estava. Nossa! É um desdobramento! A retificação de meu nome também, pra mim é um acontecimento. Imagina você chegar com... Eu chegava com RG, quando eu ia, por exemplo, dormir num hotel com Juscelino e quando eu pegava o RG, a mulher dizia: "Moça, você entregou o $R G$ errado.". Sabe? Por conta do nome. (pausa) Às vezes, eu conseguia dizer: "Não, moça, eu sou trans." e, outras vezes, eu dizia assim (gritando): "Querida, uma cidade que é cheia de travesti... Você ainda não entendeu, meu amor?". Tinha vez que eu falava assim, porque, assim... E mais hotel, onde toda hora entra travesti! Imagina todo dia você brigar por conta disso? Então, assim, você entrega seu RG tranquila, né!? É algo (pausa) que é meu! Sempre fui Fernanda, né!? Mas o meu RG é o reconhecimento do Estado de quem eu sou. O Estado está me reconhecendo, a Justiça está me reconhecendo. Civilmente eu estou sendo reconhecida. Só isso! Mas esse "só isso" tem uma mudança imensa na vida da gente. Eu acho que a retificação de nome... de nome e GÊNERO é um grande acontecimento, sim, na minha vida, pelo menos. Tem travesti que não quer retificar nome, por uma questão de militância também, que diz que ela tem que ser respeitada mesmo tendo nome civil. Talvez, pra essa pessoa, isso não gere um acontecimento. Então, pra mim, né, que vem dentro de uma outra lógica, eu não sou militante nesse sentido. É total uma questão de saúde mental! (pausa) E uma questão que é da saúde também, porque é o advogado trabalhando com o psicólogo pra fazer essa retificação de registro. Então, é uma questão de saúde também por esses dois motivos, pelo impacto de você ser questionada quando entrega o RG e também pelo trabalho em conjunto do advogado com a psicóloga ou o psicólogo. E aí... A questão da educação, que foi onde eu trabalhei e mais atuei. Se você for ver, se não existisse um programa, as pessoas não estudavam! Porque elas vão pra escola e voltam. Eu fui, semana passada, no Caetano de Campos, uma escola aqui na Praça Roosevelt, porque frequência... O programa... A gente recebe, mensalmente, a frequência das beneficiárias pra gente ver 
como está o rendimento escolar delas, pra ver se, pelo menos, elas estão indo pra escola. No Caetano de Campos, a gente não estava recebendo a frequência, então precisei ir na escola. Só pra gente entender... Eu pedi a ajuda da pedagoga daqui do Arouche, que antes eu era do Arouche, e fomos no Caetano de Campos. Quando chegamos lá, a escola estava toda fechada e falamos na secretaria. A pessoa que atendeu a gente, da secretaria, nem pra cara da gente olhou. A gente estava sem crachá. Eu: "Moço, eu queria falar com a diretora.”. (Gritando) “Espera ai!!!’, nesse tom assim. Então, assim, parece uma esquizofrenia coletiva, sabe? Parece que é normal, que isso é normal, tratar as pessoas desse jeito! Então, imagina a pessoa que a vida toda foi violada na escola e que já tem quinze anos que não está na escola e vem de cabeça baixa, com o rabo entre as pernas e tudo, e chega numa secretaria dessa e toma um berro desse! Essa pessoa nunca vai voltar! Nunca mais! Se essa foi a segunda chance que ela se colocou, ela não volta mais! E não seria evasão escolar. Por quê? (pausa) A gente chegou pra esse coordenador pedagógico e falei que a gente queria falar sobre o Programa Transcidadania e a pessoa nem olhou pra minha cara! Ele nem olhou pra minha cara! E eu sempre trabalhei numa perspectiva mais... (pausa) Dedo dentro da guela! Não tinha mais muito essa coisa de... estar fazendo rodeios pra falar e eu falei pra ele e disse: "Está tudo bem? Porque, se não estiver bem, a gente pode ir embora! Porque ficar aqui nessas condições não dá! Você com essa cara que você está...”. Fui e falei! Aí, a Flávia amou, a pedagoga, porque ela já é mais tranquila. Aí, foi aí que a gente desenvolveu a conversa, eu disse: "As meninas que estudam aqui e chegarem aqui com um atendimento desse, a pessoa não quer voltar.". Aí, ele pediu desculpa depois e blá blá blá, toda essa palhaçada! Então, a gente não consegue falar em evasão escolar, porque evasão escolar é uma escolha. Quando você evade da escola, você escolheu. Por algum motivo, você escolheu. Porque você quer trabalhar, (pausa) ou não porque quer, porque você precisa trabalhar, porque, enfim, você vem de uma origem social que você não consegue estudar, e, no caso da travesti e da transexual, ela não deixou de ir pra escola! Porque ela precisava trabalhar (pausa) pra complementar a renda em casa. Lógico que isso pode acontecer com qualquer estudante. Mas, nesse caso, a gente sabe que a pessoa foi. Por quê? Porque a pessoa, por exemplo, quando estava na escola, que é o caso da Hortência, o professor teve que colocá-la dentro do porta-malas do carro pra tirar ela da escola, porque iam tacar fogo no corpo dela! Isso é um exemplo de uma menina que foi beneficiária do Transcidadania. Então, quando eu fui fazer a matrícula dela na escola, não foi qualquer coisa que eu fui fazer, não foi uma matrícula na escola. Aquilo ali foi um evento! Então, assim, a gente teve que criar todo 
um suporte pra levar essa pessoa na escola. No primeiro dia de aula dela na escola, a gente tinha que estar na escola. Por quê? Essa menina evadiu? Se a pessoa vem tacar fogo no meu corpo, na escola, eu estou tendo escolha? Não, porque, se eu estou na escola, eu vou estar morta! Elas foram EXPULSAS da escola! Porque diretor não faz intervenção, coordenador pedagógico não faz intervenção, os pais não fazem intervenção, ninguém faz intervenção! Então não tem ninguém POR, entendeu? Não tem ninguém POR essa pessoa. (pausa) Essa pessoa já não existe! Ela é o nada! Então, assim, a fala dela não tem nenhum efeito (rindo) de verdade! Então, ela não pode se defender! Como ela vai se defender, se ela é ninguém, entendeu? Foi o caso da Hortência. Outros casos mesmo de nome social, de uso de banheiro - que a pessoa estoura a bexiga e não vai no banheiro... Todos os direitos violados! De pedrada, de carteirada, enfim, os maiores absurdos! Do porteiro da escola, que humilha e constrange; da professora que constrange; da diretora que constrange. Dentro do Transcidadania, eu estando lá na escola, acontecia! Uma professora falou que a menina ficou nervosa porque ela chamou o nome civil da menina, que não tinha motivo. Eu falei pra professora que tinha motivo, sim, que era legítimo a menina ficar nervosa e gritar e ela disse que não. A professora nervosa em cima de mim. Eu falei pra ela assim, ela falou pra mim: “Ah, tem que entender que a cultura é assim.". Eu disse: "Você tem filhos, meu amor?"; ela disse: "Tenho!”. Aí, eu disse: "Pois se sua filha for estuprada, tu pede pra ela pegar e ter complacência pelo estuprador e dizer assim 'Ai, a cultura é assim, os homens estupram e eu tenho que entender.' Se você tem uma filha negra, é a mesma coisa, se ela for chamada de macaca, pede pra ela ter complacência e dizer que a cultura é racista, que é só uma reprodução da cultura.". Eu disse assim: "Por favor, professora, tenha vergonha de abrir a boca e me falar isso!". Tinha um momento que eu dizia assim: "Meu Deus, eu vou ser demitida!", entendeu? Porque esses enfrentamentos eram necessários, porque eu não aguentava. (pausa) E eles iam fazer reclamação minha na coordenação mesmo, lá na Coordenação de Políticas LGBTI, algumas iam lá fazer. E como as pessoas sabiam o trabalho que eu estava fazendo e apoiavam, dentro da Secretaria de Direitos Humanos, eu tinha TOTAL liberdade de trabalhar desse jeito. Entendeu? E tinha efeito! Porque, assim, a gente fazia um trabalho de educar, de orientar. Um trabalho de quatro meses orientando e depois estava nas escolas. Na gestão de Haddad, isso era possível, porque o motorista deixava a gente em duas escolas, três, num único dia. Então, a gente ficava lá na escola, fazendo acompanhamento pedagógico. Qualquer conflito que tivesse, nos primeiros meses de aula, a gente conseguia fazer intervenção. Depois que a pessoa estava adaptada à escola, 
a gente não fazia esse trabalho tão diário. Então, a gente fazia esse trabalho. Mas, depois de quatro meses, o professor continuava nessa lógica de violar esses direitos... O que a gente faz? A gente mete o decreto na cara, faz denúncia e grita mesmo com professor e diretor, porque ninguém é de ferro! É isso, os professores são os maiores violadores de direitos. Os professores e diretores, entendeu? Todo o corpo docente... Toda a cultura escolar é assim. Porque, se o corpo docente dá suporte pra aluna travesti, os outros alunos baixam a cabeça, porque existe uma relação de poder. Quem tem poder é o corpo docente, na escola. Então, os alunos eles se intimidam, entendeu? Quando os alunos fazem isso na escola é porque eles têm o apoio do corpo docente. Quando a polícia bate em travesti é porque tem o apoio do prefeito, daquele que tem o poder. Entendeu? É a mesma coisa! É a mesma lógica! Ficar culpando o aluno não rola! Entendeu? Vem daí o problema!

De início, escutar de Fernanda que não tinha como saber quem ela era, devido a inúmeras ressalvas de seu cotidiano, foi dolorido. O peso em existir, aliás, o peso em não saber quem você é, parece lhe tirar a legitimidade de ser quem se é. O que existia era uma criança que não gostava de ficar de cueca como os meninos do bairro, ou sem camisa, como os jovens da (ou seria de?) família. Fernanda não reconhecia seu corpo como sendo seu. Usava blusa "segunda pele". Mas onde estaria sua primeira? Como seria a pele na qual Fernanda habitava?

Lembro-me de Arlequim, “o viajante das terras longínquas” (Serres, 1993). Com o corpo matizado, tatuado dos lugares que viajou, Arlequim chega ao meio de pessoas que cobram as histórias de suas viagens e os lugares por onde foi. A história de Arlequim estava em seu corpo e nem mesmo ele tinha conferido tal acontecimento. Desvestia-se de seus casacos rasgados pela imensidão da existência refutada por outros. Fernanda vestia-se de uma segunda pele para cobrir sua primeira, a pele de seu corpo. Ao contrário de Arlequim, não lhe cobravam suas histórias, pelo contrário, camuflavam-nas.

Juntamente a essa camuflagem, em meio aos outros e outras, era só mais uma na tentativa de não se mostrar, de não ser vista, de não correr perigo. Mostrar seu corpo era mostrar sua existência. Como mostrar uma existência negada pelo meio social e, inclusive, pela não clareza de ser quem se é?

Talvez, para uma criança, a questão de ter ou de habitar um corpo não seja tão clara. Ao nascermos, lidamos com a penumbra de sair de um corpo para este mundo, perdendo todo o cuidado, zelo, abrigo e comodidade de um lugar do qual não temos consciência, mas moramos compulsoriamente. Durante a infância, lidamos com nosso corpo a partir das ações básicas (tomar banho, alimentar-se, brincar), e, para todas elas acontecerem, é imprescindível a 
participação de um outro (nem que seja da imaginação). Como lidar com um corpo que nos foi incumbido, com o qual nem nos damos conta de que é nosso?

A dramaticidade do modo de ser criança de Fernanda parece revelar o não saber: não saber por que tem um volume ali embaixo; não saber por que se sentia tão diferente dos demais colegas; não saber por que não usava calcinha como as outras meninas; não saber por que lhe tratavam daquele modo; não saber por que teria que engrossar sua voz; não saber por que tanto xingamento e agressões. Não saber... Tudo fica cinza... Sua narrativa também aponta o não saber para quem escuta ou lê: a ciência não sabe, porque não capta este cinza.

Ser homem ou ser mulher? O que é ser homem? O que é ser mulher? Fernanda era cobrada por sentir esse peso, porém sem sua existência ser legitimada. Ela apenas morava. Tinha o corpo que lhe foi imposto, a família que lhe foi dada, o nome que lhe foi compulsório, a realidade que lhe foi imposta, o órgão sexual que lhe foi designado... Tudo em prol de um dito que, durante o nascimento, lhe ordenou e vigiou uma "vigência”: "É um menino!".

A partir de uma estrutura da ordem anatômica sexual (pênis ou vulva) é que todo o futuro de uma criança é decidido. O de Fernanda seguiu um fluxo de encaminhá-la pela via de tornarse um homem, enquanto, para ela, isso era confuso. Ao crescer e ter trejeitos do que tipicamente se entende como fazendo parte de um universo feminino, Fernanda se vê forçada a mudar seu modo de ser e de agir. É cobrada para que saiba falar como homem, se vestir como homem, se comportar como um homem, mesmo que não saiba o que é isso. É cobrada porque, se fugisse desse caminho, seria entendida como gay, quando também nem sabia o que era isso.

Em sua cidade, no interior de um estado do Nordeste, não tinha referências para entender o que se passava consigo. Sua fala resgata o que por muito se escutou/viu e ainda escuta/vê ao tratar de questões trans: “Um gay que quer ser mulher.". Levando para o plano de sua narrativa e para além dela, é nítido que há um desarranjo quando falamos sobre gênero e sexualidade. Nossos pais não estão preparados, nem nossos professores, nem nossa família, nem a escola ou nossos amigos (Louro, 2015). À pessoa que não se identifica com a norma de se enquadrar ao que lhe foi imposto fica a penumbra, enquanto, para os demais, apenas uma possibilidade é dada: a de ser um gay que quer ser mulher.

A invisibilidade da pessoa que é travesti, mulher transexual ou homem $\operatorname{trans}^{19}$ é demarcada já por esta fala. Não existe outro modo de ser: ou se é mulher ou se é homem ou mulher que quer ser homem ou homem que quer ser mulher. Há uma confusão entre gênero e

${ }^{19}$ Segundo Brasil (2015); Concilio, Amaral e Silveira (2017), adota-se essa terminologia para atentar às especificidades de cada grupo $\mathrm{T}$, especialmente no que se refere à utilização do termo associado às cirurgias de redesignação sexual, ou cirurgias de transgenitalização. 
sexo biológico, bem como entre todas as outras nuances que demarcam a vivência da sexualidade, podendo ser tiradas da questão. Sua existência é negada, ilegítima (Butler, 2015, 2016).

Chamo atenção para "o que quer ser". Nessa fala, fica imbuído o modo como estamos habituados a encarar questões cotidianas como simplesmente um artefato que usufruímos como possibilidade de dizer sim ou não. No entanto, a fala, por si só, é uma representação. Só se é mulher ou homem de verdade quem nasce mulher ou homem e, aparentemente, quem tem desejos e sonhos que trilham na mesma direção. Ser a pessoa "que quer ser" apresenta-se como algo em vias de processo/projeto, de algo que é futuro, ameaçando o presente da presença humana, ou seja, sua possível inexistência.

Ser lésbica, gay, bissexual, travesti, mulher transexual ou homem trans é ser uma figura, a representação de um projeto ameaçado pela lógica determinista de conformidade entre sexo biológico, gênero, orientação sexual, desejo e corpo (Bento, 2006, Butler, 2009). Se tais nuances não estiverem agindo a passos ajustados, instala-se a doença. Assim era com os humores de Hipócrates, e assim parece que também a humanidade foi se fazendo, numa dimensão relacional do e com o corpo. À criança a que "sobra" tal descompasso "sobra" também o peso de dar conta de coisas que nem mesmo sabem os pais, a família, os professores, a escola e seus amigos.

Ao narrar que não tinha referências, Fernanda sinaliza que a trajetória de uma pessoa trans durante a adolescência é de uma confusão maior do que a de uma pessoa cis. A diferenciação do corpo feminino e do corpo masculino, nesta época, é um ponto que provoca diversas (i)mobilizações na experiência corporal. Espera-se que um menino cresça e que seu corpo, notoriamente, traga referências típicas de "homem", como crescimento de pelos (especialmente no rosto), voz firme, postura ereta e viril; para a menina, são esperadas dimensões corpóreas que trazem visibilidade maior e mais nítida do que nos meninos, tornando-se "mulher" aquela que menstrua e tem seios, quadris e nádegas crescidas.

Por si só, tal “esperança social” abriga já uma questão que emboca numa construção social de corpo (Weeks, 2015), na qual, para a mulher, resta o desenvolvimento nítido de uma sensualidade, expressa por um corpo avantajado, objeto de desejo masculino; enquanto, para o menino, espera-se características que o coloquem num posicionamento de poder, expressas pela rigidez, aptidão sexual e virilidade.

Para Fernanda, "transar na condição de gay" lhe gerou desconforto, uma vez que nem se identificava como homem, e, mesmo assim, não tinha características corporais esperadas para uma mulher, como aumento de seios e curvas. A presença de seu corpo com trejeitos mais 
delicados, como a mesma conta, também denotava a ausência das características "femininas". Não tê-las causava-lhe desconforto, pois a emoldurava numa androginia que nem mesmo ela compreendia. "Transar na condição de gay" era aprisionar seu corpo num corpo masculino, ao mesmo tempo em que indicava uma identidade de gênero e orientação sexual às quais não lhe competiam.

Assmann (2013) ressalta que esta compreensão de corpo circunscrita pelos ideais científicos presume que "o próprio corpo só pode ser cognoscível se o tomarmos como coisa, como simples realidade mensurável, como conjunto de órgãos, separável em partes cada vez menores." (p. 27), o que reverbera no modo como lidamos com ele na prática profissional, em especial em práticas de cuidado que tangenciam a esfera da saúde. Para este autor, a visão de corpo que perfazemos e lemos é uma herança deste modo de compreender e viver o próprio corpo. Assumimos o corpo como uma delegação de um "acaso", como se "tivéssemos" um corpo, uma propriedade que pode sofrer ameaças externas (Assmann, 2013).

No entanto, se olhando por este prisma, pode-se questionar: Será que o corpo que "temos" é realmente nosso? De fato, o pensamento metafísico conhecido, deflagrado pelo norte dos binarismos (como "saúde-doença", "mente-corpo", "corpo-alma", "vida-morte", "homemmulher"), refuta a experiência do mundo contemporâneo. Para a questão colocada, em meio ao arsenal de outras questões que suscitam no desenvolvimento da ciência, das biotecnologias, das parafernálias do poder e do campo da biopolítica, é quase unânime dizer: "Nosso corpo não é nosso!".

Desse modo, a narrativa de Fernanda demarca bem como o corpo-existência, para a pessoa que ainda não transicionou ou, dizendo de outro modo, para a pessoa que ainda não readequou seu corpo à sua identidade de gênero, é demarcado para uma realidade empreendida na lógica do binômio homem-mulher. Não ter as características necessárias para ser "uma mulher de verdade", em decorrência de um corpo anatômico masculino, transmitia a ideia, para os homens, de que Fernanda seria um homem gay, não uma mulher. Ao mesmo tempo, tais características ausentes demarcavam a tensão entre o desejo de um corpo "que se quer" e o corpo material que circunscrevia sua experiência, simplesmente.

Apesar de seu desejo voltado para homens e de não se encaixar numa normatividade de corpo, Fernanda não consegue nomear o que é. Durante a vida acadêmica, esbarra com referências teóricas que indicam, minimamente, que existem outras possibilidades no campo do "ser mulher" ou do "ser homem". As referências também começam a brotar a partir de sua vinda a passeio a São Paulo, quando vê que a grande presença de travestis na cidade lhe causa desconforto, mesmo não querendo "ser como elas". 
Pela sua narrativa, as pessoas, que indicaram que talvez ela não fosse um homem, abriram a questão da legitimidade de sua identidade para a própria Fernanda. Esta demarcação apresentou-se a mim como importante, uma vez que a identidade de gênero deve (ou deveria) ser autodeclarada a partir de como a pessoa se identifica - ao contrário das ciências naturais, que delimitam, vigiam e delegam quem é o(a) trans de verdade (Bento, 2006; Butler, 2009, Oliveira, 2014).

A partir da experiência de moradia de seu corpo, sua identidade, que não estava clara, e os indícios de pessoas próximas que apontavam outras possibilidades de ser Fernanda, é que ela inicia pesquisas em diversos meios, com o intuito de melhor se conhecer e compreender. Ou seja, abriu-se a possibilidade de Fernanda iniciar a busca por poder ser quem se é ${ }^{20}$.

Assim, a utilização de hormônios à base de estrógeno (tipicamente feminino) foi a primeira intervenção de readequação corporal à identidade de gênero. Este recurso, como ela mesma aponta, é comumente utilizado por pessoas trans e travestis como uma maneira de experienciar um corpo que se aproxima do modo como eles(as) se identificam. Questiono: a experiência do corpo é anterior ou sucede à identidade de gênero? É possível pensarmos a partir desta lógica?

Acredito que não. Em vias de uma "transição", a experiência de uma identidade que possibilita "ser homem" ou "ser mulher" já vem por si só acompanhada de uma experiência que está relacionada ao corpo. Ora, como lidar com um corpo que não compreendo e que causa confusão em detrimento do que se conhece por homem e mulher? Como legitimar corpo e identidade de gênero senão pela lógica de adequação de um com o outro?

Tanto os ideais feministas quanto uma compreensão de corpo que se desprende de uma “amarra de poder sobre poder" dão abertura para pensar o corpo por fora de um binômio. Heidegger (2012), em sua analítica da existência ${ }^{21}$, compreende o homem como Dasein, “aíser", a existência sempre em movimento, em forma de pro-jecto. Em sua filosofia, ser humano

\footnotetext{
${ }^{20}$ Isso afina-se à compreensão heideggeriana acerca do poder-ser. Tal compreensão alinha-se na perspectiva de entender a existência do humano como um pro-jecto lançado à frente, em movimento. Aqui, entendo que o movimento de Fernanda se aproxima da condição de pro-jecto, amparado pela angústia (condição fundante das (in)determinações que permitem Dasein considerar a de-cisão que lhe afeta: apropriar-se ou extraviar-se e desconhecer-se).

${ }^{21}$ Importa destacar que a tese pretende caminhar numa atitude fenomenológica, como um modo de debruçar-se sobre os fenômenos, não de pressupostos da fenomenologia existencial como base para as discussões oriundas da questão de pesquisa. Esta colocação é necessária por entender que, epistemologicamente, discussões em torno do corpo, da política e da saúde necessitam de uma intersecção de olhares que pretendem construir um sentido para o fenômeno interrogado. Assim, faço uma observação de que, mesmo que incorporada algumas ideias de Martin Heidegger, as discussões posteriores (especialmente no último capítulo) dar-se-ão a partir de uma leitura fenomenológica de alguns apontamentos de Hannah Arendt. Assim, a tese não pretende focar em terminologias específicas da atitude filosófica heideggeriana, mas destinar um olhar fenomenológico e caminhar nesta atitude.
} 
e mundo estão intrinsecamente revelados a partir do modo de ser do Dasein. Para o filósofo, Dasein é existência e, sendo existência, não haveria, pois, como classificá-lo, ou seja, não haveria fundamento para pensar um Dasein como preto ou branco, rico ou pobre, mulher ou homem. Dasein é o aí, imerso no mundo-com-outros.

Numa leitura fenomenológica a partir destes fundamentos heideggerianos, é possível compreender que, na abertura do mundo, ou melhor, no modo como o humano experiencia o mundo é que estas confabulações foram sendo inscritas e circunscritas. Categorizou-se classe social, etnia, sexo biológico, gênero, que, assumidas em prol de um movimento técnicocientífico, acabaram por justamente esquecer que o corpo, mais que o lugar no qual se inicia a vida, é antes de tudo um arsenal pelo qual a vida acontece e o humano se conhece.

Perseguindo esta perspectiva, entendo que a invisibilidade dos corpos trans e travestis, no campo da saúde, aparecem como "porta de entrada" para temas médico-sociais. Tal consideração é possível de ser feita na medida em que compreendo que tais questões são incorporadas como centralização de um modelo médico como prática que depende da constituição do binômio saúde-doença.

Para Bento (2011), "Se reduzirmos a noção de existência à experiência singular e não a vincularmos a uma cadeia de significados que antecede ao sujeito, terminaremos por encontrar o indivíduo como fonte explicativa de tudo" (p. 18). Esta noção, atrelada à noção de Dasein, perfaz o caminho para conceber e compreender o fenômeno do corpo trans como fundamentalmente uma nuance relacionada com outros; sempre, então, uma construção política, feita e realizada pela troca entre pessoas.

No campo da transexualidade, essa questão é de extrema importância. Fernanda conta que, para ela, era preciso que adequasse seu corpo à sua identidade. No entanto, esta "escolha" diz da realidade, particularidade e singularidade de cada um(a), pois não é o corpo ou suas características anatômicas que vão determinar o gênero. Muitas pessoas trans e travestis não recorrem à utilização de hormônios ou cirurgias de adequação corporal para estabelecer esta identificação. Desta feita, o discurso e poder de fala, no campo da transexualidade e travestilidade, sinaliza uma complexidade tal que desconstrói toda uma dimensão empreendida pelo pensamento científico da modernidade - pelo menos no que diz respeito à experiência.

A utilização de hormônios com a finalidade de adequação corporal à identidade de gênero é um recurso recorrente na realidade de muitas pessoas trans e travestis (Brasil, 2015). Seu uso por esta população, em grande maioria, é feito sem prescrição ou acompanhamento médico, uma vez que não requer a receita do fármaco para aquisição - pelo menos para a mulher transexual e para a travesti. 
Durante os atendimentos que fiz quando fui parte de uma equipe multidisciplinar no atendimento voltado a esta população, era recorrente este tipo de uso de forma "irregular". O uso de hormônios sem acompanhamento pode gerar inúmeras complicações de saúde. Sempre questionei por que estas pessoas não conseguiam tal acompanhamento, uma vez que a própria Portaria do SUS ${ }^{22}$ designa as Unidades Básicas de Saúde (UBS) como sendo responsáveis por este tipo de acompanhamento, como porta de entrada. Quando estava em vias de escrever o projeto para tentar o doutorado, consegui mapear nove UBS que estavam "habilitadas" a fazer este acompanhamento.

No entanto, ao chegar a São Paulo, a realidade foi assombrosa. O meu espanto não foi em vão. Descobri, durante a época deste trabalho, que várias caixas de hormônio eram descartadas por várias UBS. Como não se deixar assombrar com uma informação desta? Seria uma falta de procura desta população ou falta de investimento em políticas públicas que favoreçam a autonomia do sujeito em buscar acompanhamento? A saúde está a favor de quem, ou melhor, a favor de quê?

Autonomia... Talvez seja esta a grande "jogada" descartada quando se trata da população trans nos serviços de saúde: autonomia para quem? Para quê? Como? Os princípios básicos do SUS visam à autonomia do sujeito como um fator importante para a aderência às estratégias e aos serviços. Será que há autonomia, quando se pensa em serviços públicos de saúde? O descarte da "jogada", assim como dos hormônios fora do prazo de validade, denotam que não é somente o direito da pessoa que é violado, mas o próprio direito de ser quem se quer ser é posto em questão. Quem eu posso ser, quando me deparo com a burocracia para autorizar minha existência? Aliás, tenho autonomia do, com e para meu próprio corpo?

O discurso médico, marcado pela lógica mercantil-farmacêutico-científica, é carregado de poderes (Foucault, 2017). Para além disso, vou adiante com a narrativa de Fernanda:

Demorou muito tempo! Pra pegar hormônio demoraria seis meses pra isso acontecer, porque a quantidade de consultas e de exames... Tudo isso pode ser feito em uma semana, não precisa dessa demora toda!

Seu depoimento demarca bem como a saúde compreende o acompanhamento desta população, especialmente quando conta sua história pessoal no que diz respeito ao seu primeiro atendimento médico para a hormonização ${ }^{23}$. A burocracia, que na visão de Fernanda se torna

\footnotetext{
${ }^{22}$ Portaria n. 1.707 , de 18 de agosto de 2008.

${ }^{23}$ O termo "hormonização" é também chamado de "hormonioterapia", no campo da saúde. Escolheu-se por chamar de "hormonização", neste trabalho, seguindo a compreensão do movimento T, que define o termo "hormonioterapia" como uma prática centrada na reparação de um hormônio sobre outro, reparação de um corpo.
} 
impedidora de uma autonomia, demarca como na saúde (aliás, como em várias esferas do viver cotidiano) nosso corpo nunca é nosso. Nessa direção, chama atenção o modo como Fernanda lida com a situação e o atendimento feito pela médica:

É melhor me receitar, porque não vai adiantar de nada! Eu vou lá na Rua Aurora e eu vou comprar hormônio e vou tomar. A única coisa que você está fazendo é me fazer gastar ou fazer com que eu me prostitua, porque eu vou pra esquina atrás de dinheiro pra tomar hormônio. Ai, você vai me colocar numa situação de risco maior que me dar o remédio, porque, se você me der o remédio, eu vou tomar, e, se você não me der, vou ter que procurar outros caminhos, mas não vou deixar de tomar.

Este realce da narrativa sinaliza a preocupação de Fernanda em torno de sua saúde. Esbarrar com a burocracia, na visão dela, pode acarretar várias situações de risco para a população trans, como o uso por conta própria de quem tem poder aquisitivo possível ou levar à situação de prostituição (realidade de muitas travestis e mulheres transexuais), quem não têm acesso a um poder aquisitivo que lhe supra. No entanto, ainda que essa demarcação sinalize o descaso da saúde com a travesti e com a pessoa trans, aponta para outra realidade que, na minha experiência como psicólogo, é bastante presente.

Muitas travestis e mulheres transexuais que recorrem à situação de prostituição como forma de trabalho passam, ainda, por um descompasso entre o próprio grupo T. A travesti e/ou mulher transexual "que faz rua" precisa ter "um corpo de mulher", e quem não tem este corpo é tida como "um gay que veste roupa de mulher", ou "um viadinho", como escutei durante muitos atendimentos. Será que o discurso trans também corrobora uma construção de corpo determinada pelo cientificismo moderno? Ou os clientes que procuram pelos serviços sexuais de travestis e de mulheres transexuais, em situação de prostituição, pedem por um "padrão de mulher" visível, e, por isto, a população recorre a modificações corporais para aquisição de renda? Mais ainda: seria o corpo o demarcador social, para a pessoa trans, que ratifica "quem é a trans de verdade"?

Tais questões embocam na narrativa de Fernanda, ao contar que, a partir de sua vinda para São Paulo, foi difícil e sofrida a vivência de se identificar como trans, uma vez que vinculava esta realidade à figura de um monstro: "Eu não queria ter aquele corpo...”. Que corpo?

\footnotetext{
Nesse sentido, presumo que a prática de hormonização carece de um sentido diferente para os profissionais de saúde, por atentar-se a uma experiência do corpo a partir de um modo de ser que não se sustenta no reparo, adequação ou construção daquele.
} 
Ao falar sobre isto, Fernanda justifica sua "negação" de um corpo como o habitual da população trans apoiada a uma construção social demarcada pelo contraste da realidade "da rua". Para ela, ter "aquele corpo", "aquela linguagem", "aquele comportamento" e viver "naquele contexto" era estar à margem de um padrão de normalidade para um corpo feminino e, mais ainda, para ser mulher.

Estar à margem parece se configurar não somente em torno das adequações corporais à identidade de gênero, mas também em torno de questões da realidade vivida (Butler, 2016). O não reconhecimento de um nome social, a recusa de profissionais em acompanhar a pessoa trans, o embate político que entra em voga, a figura da travesti e da mulher transexual lida a partir da prostituição e/ou criminalidade pelo imaginário social e as características anatômicas da pessoa trans são "portas que se fecham" e excluem. As portas se fecham e deixam de fora, inclusive, a criança que começa a dar indícios de que não tem sua identidade em conformidade com a anatomia do seu corpo.

Imagino essas portas como as do "País das Maravilhas", sempre como uma caixinha de surpresas. Aqui, recorro ao aspecto do mistério como importante para pensarmos o fenômeno em seu aparecimento, tal qual Fernanda aponta sobre sua identidade de gênero. Para Heidegger (2011):

O que não se fala não é somente o que não deixa verbalizar, mas o não dito, o que ainda não se mostrou, o que ainda não chegou a aparecer. O que, portanto, deve-se manter-se impronunciado resguarda-se no não dito, abriga-se no velado como o que não se deixa mostrar, é mistério. (p. 202)

Seguindo esta perspectiva, entendo o mistério como aquilo que ainda não foi desvelado, que está encoberto. Isto implicaria a possibilidade de algo ser esclarecido, tematizado, dado a conhecer pela luz. Seria possível abrir e fechar as portas com o próprio corpo? Ao entrar por uma porta que não se sabe onde vai dar, o mistério entra em voga; porém, se não entrar, o mistério também permanece.

Pela narrativa de Fernanda, compreendo que estas portas sequer têm maçanetas. É difícil abrir sozinha ou arranjar algum macete que consiga abrir uma porta. Em sua história, fala que desenvolveu “[...] também uma postura muito reativa, acho que muito por conta disso. [...] Nunca conseguia falar, porque eu era tratada desse jeito [...]?”, e, a partir daí, ela começa a entender o porquê do imaginário "dos monstros" lhe assustara: era preciso reagir, e era de uma forma reativa que as travestis e pessoas trans agiam, para ela. 
O modo reativo de falar, por parte de usuárias, ou de responder a perguntas se tornou bem recorrente em minha experiência com a população trans. De início, assustava-me o modo como muitas vezes era tratado por algumas usuárias do serviço. Com o passar do tempo, o contato com este grupo revelou-me que o caráter "reativo" é um modo de "não deitar"24" e resistir a inúmeras vulnerabilidades decorrentes do movimento em existir como trans ou travesti.

Uma destas vulnerabilidades, na infância/adolescência de uma pessoa trans ou travesti, é o modo como são tratadas no ambiente escolar. O bullying, ou melhor, a transfobia é bastante recorrente neste contexto. Fernanda narra que as "brincadeiras" de chateação dos colegas de turma, durante o ensino fundamental, era motivo de sofrimento extremo, tornando-se "[...] $a$ mesma história que tem por aí com muitas transexuais e travestis.".

O xingamento, o escárnio e as piadas no campo da sexualidade, dentro da escola, sempre tiveram peso na vida de pessoas transexuais e travestis. É recorrente o "abandono" da escola para com estas pessoas, ainda nos primeiros anos escolares, em decorrência da forma como são tratadas e (in)compreendidas. O uso do banheiro e a atenção e respeito ao nome social, por exemplo, são peças importantes na vida de uma pessoa trans, especialmente na escola. Nesta direção, todo o despreparo, descuido e descaso das equipes da educação são reverberações do movimento político do contexto, movimento este que reafirma, normativamente, a docilidade da educação que é perpassada por uma questão de vigilância e punição (Louro, 2015).

Sua existência, para os outros, é frágil por ser compulsória. Criam-se corpos domesticáveis, que podem ser manejados e excluídos, ao ponto de formar atitudes violentas sérias que vão da segregação até a morte. "Olha só a que exposição uma criança pode ser posta!" na escola, em sua família, no seu meio social, como um corpo e presença que nunca foi (e nem será) seu e sua.

É neste sentido que, o "abandono" falado não cabe no ambiente escolar, no tocante à "desistência" de uma pessoa travesti ou trans. O abandono, se assim se pode falar, seria mais um abandono das amarras institucionais e coletivas que aprisionam o modo de ser travesti e trans, do que um abandono da institucionalidade da educação. Fernanda expressa, em sua narrativa, que esta atitude é um condicionamento que implica uma expulsão. O sistema escolar expulsa travestis, mulheres transexuais e homens trans. Expulsa porque ali elas não cabem. Expulsa porque o modo de viver normativo de uma instituição demarca fronteiras (ou melhor, limites) que deixam evidentes quais os "papéis" e "deveres” de um instituído, quer institucional quer existencial.

\footnotetext{
${ }^{24}$ Expressão que geralmente é utilizada por travestis e mulheres transexuais para dizer que não dá para "engolir" ou "baixar a cabeça" para determinadas situações.
} 
A ex-pulsão demarca uma veia que não mais pulsa. Necrosada pelo sistema, é indicado silêncio, para que na voz calada não se emane um pedido. A transexualidade e travestilidade não são faladas na escola. Muito se diz sobre a travesti ou sobre a pessoa trans, mas pouco se sabe com travestis e com pessoas trans. Ou melhor, muito se diz ou se constroem repertórios que aprisionam as especificidades destas existências; no entanto, pouco se fala de maneira coconstruida com estas pessoas. A veia que não pulsa na educação (e na saúde) pulsa na vida cotidiana e, mesmo necrosada pelo sistema, o pedido é um apelo.

É nesta direção que penso que os programas sociais desenvolvidos para esta população não devem servir como uma forma de reparo ou controle social. Entendo que as especificidades desta população pedem por uma veia que pulsa - e não somente a partir da ex-pulsão. Tais programas denunciam o despreparo das equipes educacionais que entendem que o papel de educar é uma representação e diagramação de um currículo que é falho, indicando que, mais do que reparar um dano, é necessário pressionar os serviços.

Tais pressões, no âmbito dos serviços, dizem da necessidade e da precisão de questionar as políticas (ou a falta delas) que emergem (ou são castradas) das instituições públicas, em especial as de educação e saúde. Neste sentido, educação e saúde misturam-se. Misturam-se porque a veia que agora pulsa revela a complexidade em detrimento do próprio sentido de política. A gestão e o processo de gerir centram-se nas necessidades de concretização de metas de governo que são fundamentadas por uma lógica de bem comum. Bem comum para quem? A serviço de quem? A serviço de quê?

Concebendo a política como "acordos que se dão entre homens", a ação e condução desta ação se voltam para a pobreza de relações e vigora a ordem de controle. Se for deslocada a lógica de que o homem é o responsável por fazer política, toda uma conjuntura é posta em xeque. Por que nossa cultura ocidental é demarcada pela ação do homem e por que os jogos de poder políticos são alocados sob sua ação e produção? Pensar a partir desta lógica, centrando o vocábulo universal "homem" - lê-se homem, branco, classe média alta, cis, heterossexual e heteronormativo - para as ações humanas, é ofuscar e deslegitimar todas as outras configurações não-homens. Por que não falar que a política se dá entre pessoas?

Centrar o poder e suas nuances nas mãos de todas e de todos parece causar espanto. Ora, o poder verticalizado representa e demarca toda uma democratização, deixando a ver que a transexualidade e travestilidade não precisam ser discutidas, sendo, por isso, demarcadas como temas "transversais" nas instituições de saúde e educação. Talvez, a necessidade seja de fazer o contrário: relocar um tema "trans-versal” para que seja possível versar sobre ele. 
Sobre os possíveis versos, Fernanda situa o momento atual vivido, demarcando alguns "nortes" que atualmente se tem no campo das questões de gênero. Situa a mídia como um importante veiculador da temática da transexualidade e da travestilidade para, em especial, as camadas sociais que têm menos acessos a recursos de informação. O destaque que dá à novela ${ }^{25}$ parece ser revelado por Fernanda como esta possibilidade de o assunto ser tocado e levado a público. Durante sua exibição, a novela desencadeou uma série de críticas - tanto de pessoas, grupos e instituições religiosas fundamentalistas, de um lado, como do movimento LGBTI, de outro - que subsidiaram várias reportagens e destaque na televisão e na imprensa como um todo.

Na semana em que fiz a entrevista com Fernanda, veiculava na imprensa a edição da semana da revista Veja (Edição 2552 - 18 de outubro de 2017), à qual recorri. Críticas à parte - tanto ao recorte político no qual a Veja se fundamenta, quanto ao modo como caricatura as informações de seu conteúdo -, a revista suscitou inúmeras questões. Trazendo na capa um homem de costas com uma criança, de frente, em seus braços, o título em negrito e caixa alta, “MEU FILHO É TRANS", centraliza o vocábulo masculino como o centro da questão. No canto direito, ao lado da imagem, a revista traz o seguinte: "O empresário Anderson de Almeida com a filha Carolina, de 6 anos, que se chamava Murilo”. A reportagem, de Giulia Vidale, traz o depoimento de mães e pais que experienciam a maternagem e paternagem de "crianças trans". Por vezes, há uma confusão entre os termos "identidade de gênero" e "identidade sexual", que são utilizados como tendo o mesmo sentido, mas que são determinantes para a compreensão de que, mais uma vez, a noção de gênero para muitas esferas está subsidiada aquém ou até mesmo interligada ao constructo "sexo", ou melhor, a uma identidade que se fundamenta na atribuição de nascimento.

Para além de uma "confusão" conceitual ou da escrita, é assinalado que "Os transgêneros fazem parte do cotidiano brasileiro, e já não se pode fingir que não existem, apenas por não combinarem com o padrão. Nem são muitos - 0,5\% da população mundial [...].” (Vidale, 2017, online). Essa informação, indicada de uma maneira que chame a atenção de quem lê, presume que a população é marcada pela invisibilidade. A invisibilidade que questiono é calcada não no quantitativo de importância/relevância da existência destas pessoas, mas elaborada pelo plano

\footnotetext{
${ }^{25}$ Trata-se da novela "A força do querer" (2017), escrita por Glória Perez e dirigida por Rogério Gomes e Pedro Vasconcelos, da TV Rede Globo. A novela traz o personagem Ivan (antes, conhecido como Ivana), que na história aparece como um homem trans. O personagem Ivan passa por várias situações de violações de direitos e discriminação, não somente por ser um homem trans, mas por também ser gay. Mesmo que, como Fernanda coloca, a novela tenha sofrido inúmeras críticas do próprio movimento LGBTI, por situar a questão de uma maneira não muito "representativa" ao movimento trans, ela parece revelar uma possibilidade de a questão de gênero ser colocada como importante.
} 
de fundo (ou seria de figura?) que relaciona o gênero com a normatividade binária, ou seja, a de que gênero é atribuído como sendo "mulher" ou "homem".

Vou aos comentários da reportagem online da página da Veja na internet:

Boicotem, trans isso ou aquilo e transtorno psicológico nao imponham isso aos seus filhos. Chega! Tenha vergonha VEJA!

Mas como que isso pode ter aparecido só agora? Se fosse uma condição humana, sempre teria existido. É óbvio que é modismo.

VEJA acabou. É incrível como a pauta da esquerda dominou completamente a revista. Perdemos um dos últimos bastiões conservadores do país. Triste ver como a mídia hoje é de esquerda ou de extrema esquerda." ${ }^{26}$.

Chamo atenção para apenas estes três comentários e começo a relacionar com o parágrafo da reportagem escrita pela colunista. A "condição humana" à qual a travestilidade e a transexualidade estão determinadas está, de um lado, fundamentada por uma lógica biologicista, atrelada ao binarismo homem-mulher, como sendo as únicas possibilidades de existência; de outro, relaciona-se à pluralidade destas existências atreladas ao movimento político brasileiro dito de esquerda.

Fernanda, ainda em sua fala sobre a veiculação da mídia e a importância de sua participação na conjuntura que o Brasil está vivenciando, aproxima-nos da complexidade que é demarcada pela falta de informação das pessoas, principalmente das gerações anteriores à nossa. A definição da temática como sendo "modismo" ou mesmo de que "não são muitos", disponível na matéria da Veja, denuncia a inexistência de espaços que priorizem a necessidade de disseminação de informações e sensibilizações em torno da temática.

Esta necessidade aponta não só da importância em os serviços estarem afinados com o discurso da legitimidade, igualdade e integralidade das ações desenvolvidas, mas da necessidade de não se apagar existências que são colocadas como "minorias". Será que é somente $0,5 \%$ da população mundial que não se encaixa no padrão conservador de gênero, corpo, orientação sexual, desejo e sexualidade ou são $0,5 \%$ destas pessoas que conseguem chegar até estes serviços? Mais ainda, são estes $0,5 \%$ que chegam aos serviços ou é apenas $0,5 \%$ que se consegue mapear pelos instrumentais que demarcam gênero como "homem" e “mulher"? Será que estes indicadores não se confabulam em torno da própria confusão da categoria gênero com a categoria sexo elaborada pela "política” destes serviços?

\footnotetext{
${ }^{26}$ Trechos extraídos da página de conteúdo online da Veja, fiéis aos dos comentários.
} 
De fato, com o aumento destas informações disseminadas de variados modos, o assunto das generidades ${ }^{27}$ vem se tornando importante para a academia e instituições como um todo. Como Fernanda pontua, seja como for, estes modos de veiculação possibilitam que o assunto saia da "crueza" e tome espaços que, de certo modo, tornam-se referências não como disseminação, apenas, mas como ação política que se dispõe a ou para, uma ação que se destina com-partilhada e não que "fale por" ou "diga de".

A partir da minha experiência com a população de travestis, mulheres transexuais e homens trans, tenho compreendido que o lugar de fala de cada pessoa em específico é sempre em torno da experiência singular, comumente expressa em suas narrativas. No encontro com Fernanda, isto também é bem comum, quando convoca ao chamamento de importância e evidência para sua experiência. Neste sentido é que se faz necessário de os estudos das generidades se voltarem às travestilidades e transexualidades, no plural, de modo que nenhuma especificidade se sobreponha à outra e, ainda, que nenhuma experiência diga da vivência de outro/(a).

O realce de Fernanda para a sua experiência de transição ${ }^{28}$ é um dos momentos mais crus do encontro. Tinha ouvido sempre falar sobre como é difícil e doloroso esse processo e que, muitas vezes, indica a morte de uma pessoa que existia num corpo errado e passa a iniciar uma nova vida. Fazendo um paralelo do corpo enquanto casa, este modo de "transitar" pelas vias do corpo por meio de readequações que con-versam com e acerca da identidade de gênero, possibilita uma compreensão de que é o momento de abandonar as malas de uma viagem cansada, pesada, e passar para a experiência de habitar um lar.

Todo o movimento de Fernanda em falar (e tocar) sobre (o) seu corpo, aproxima-nos da complexidade, importância, responsabilidade e (des)cuidado em torno da construção cultural e social que é o corpo. Ao falar sobre as bombadeiras, os métodos de alterações corporais, a falta de preparo da profissional que faz as alterações, os recursos utilizados durante o procedimento e o modo como se lida com o corpo da travesti e da mulher transexual, lembro sempre de Fernanda demonstrando com o dedo a espessura da agulha para injetar silicone industrial.

Todo procedimento de reparo, através dos serviços de uma bombadeira, de um corpo que não está em conformidade com uma identidade de gênero demarca, notoriamente, um problema

\footnotetext{
27 Termo cunhado pela academia para, de certo modo, englobar as diversidades de identidades de gêneros que fogem do binarismo homem-mulher.

${ }^{28}$ Grosso modo, termo que diz da ação referente ao momento no qual a pessoa trans ou travesti inicia readequações corporais à sua identidade de gênero. Embora o termo "transição" esteja relacionado à readequação ou redesignação de um corpo a um gênero pelo qual se identifica e se experiência, penso nesta readequação como um modo de "transitar" pelo corpo como possibilidade de ser, indicando a potência de tais corporalidades.
} 
de saúde pública (Brasil, 2015). Mas realmente seria só de saúde pública? A quem ou para onde recorrer quando seu corpo é configurado como uma posse calcada por um controle social?

Fernanda aponta para cada lugar onde lhe foi injetado o silicone industrial como forma de moldar seu corpo a um corpo que queria. Mesmo com anestesia, diz que a dor é descomunal e, como o material é espesso, é necessário de uma agulha que consiga expelir o silicone em gel no seu corpo - o que não é diferente nas demais mulheres transexuais e travestis.

Em sua narrativa, demarca a importância do que entendeu como redução de danos, ao comprar seu próprio material descartável. Aqui, lembro novamente de sua primeira consulta com a médica que lhe receitou os hormônios e da fala de Fernanda em resposta à atitude da médica em revelar todo processo demorado para iniciar o acompanhamento com os hormônios. Assim como o acompanhamento hormonal parece indicar uma redução de danos em torno da saúde desta população, a própria aquisição dos materiais descartáveis que serão introjetados no corpo indica que pouco se dá importância, ou melhor, que pouco se sabe sobre esta população e sobre as diversas vulnerabilidades que circundam o campo da saúde.

Nos primeiros momentos de readequação do corpo à sua identidade de gênero, Fernanda conta que começou com o uso de hormônios sem acompanhamento e, logo em seguida, colocou próteses de silicone nos seios. Após a cirurgia para próteses, fala que procurou uma bombadeira e colocou

dois litros de silicone. Coloquei... E eu não queria aquele corpo do jeito que ficou. Ficou um corpo super natural e eu não quis. O meu ideal... acho que por eu assistir desenho animado, tipo Betty Boop... eu queria um CORPÃO daqueles assim (faz gestos para identificar um corpo com cintura e quadris largos), daqueles da Disney. Aí eu fui e quis mais. Essa foi minha história. [...] Ai fui atrás de outra [bombadeira] e ela colocou. E eis aqui esse corpo! [...] A minha bombadeira utilizou anestesia. Anestesia de cavalo também. Não é anestesia de humano. [...] no meu caso, doeu muito, mas não doeu tanto como as meninas que se bombavam, que ainda se bombam, que se bombavam há dez anos... que não tinha... era feito no cru, assim (dá socos na mão) sem nada! Você aguentava aquele líquido entrando no seu corpo.

Para mim, foi extremamente doloroso ouvir a narrativa de Fernanda sobre as dores possíveis decorrentes de um procedimento de bombeação. No entanto, tudo o que senti através da escuta de seu depoimento não diz de um por cento da dor física que uma travesti ou mulher transexual - ou mulher cis - sente durante o processo. Se uma dor física dói a ponto de muitas não suportarem e, ali mesmo, em camas com lençóis limpos - porém despreparados e longe de qualquer procedimento estéril e de assepsia -, imaginemos como deve ser pesado e doloroso existencialmente ter que recorrer a um procedimento tão invasivo como este. 
Fernanda foi uma das meninas para quem o procedimento deu certo, sem complicações durante e/ou depois, diferente de muitas travestis e mulheres transexuais com quem tive contato acerca da experiência clínica. Sua demarcação de que tal procedimento é procurado também por mulheres cis chama atenção, porém, a dimensão do lugar de existência (e resistência) do corpo de uma travesti e mulher transexual, que procura pelo serviço de bombeação, é diferente dos motivos da procura de uma mulher cis.

A mulher cis já habita um corpo que, anatomicamente, é designado ao sexo biológico feminino, enquanto a mulher transexual e a travesti são designadas a redesignarem-se aos corpos que lhes foram impostos (Bento, 2006). Só assim, tendo acesso a um serviço "precário, ...é [que se encontra] a única forma de se construir o corpo que se quer. De uma maneira mais rápida!", de forma que sua existência seja autenticada, legitimada pela presença de características que lhes tornem "passáveis",

Porque a travesti, realmente, é uma readequação do corpo. A mulher cis é outra coisa: ela quer dar mais forma, ficar mais bonita. Não que a trans também não tenha isso em mente, mas é outra coisa você querer readequar seu corpo do que só estético.

O termo passável advém da palavra passabilidade. Este conceito, no campo das transexualidades e travestilidades, é empregado para as pessoas que têm suas características anatômicas (expressão corporal, rosto, voz, cabelos) confluentes às de uma pessoa cis. Como Fernanda fala "se você tem a passabilidade, você vai sofrer menos. Se você tem a passabilidade, você vai ser reconhecida como mulher.", ou seja, quanto mais readequar o corpo à aproximação de características típicas da anatomia corporal de uma pessoa cis, mais esta pessoa é passável e se torna "despercebida" como trans ou travesti.

Aqui, duas coisas chamam-me a atenção. A primeira diz respeito às dificuldades encontradas pelas travestis, mulheres transexuais e homens trans em readequarem seus corpos à construção corporal conforme suas identidades de gênero, recorrendo a diversos recursos precários e serviços despreparados, dando indícios de que há um mercado de compra e consumo em torno da passabilidade. A segunda direciona em torno de uma higienização de corpos, como se os corpos aceitáveis e memoráveis fossem aqueles que melhor "passam" como sendo cis, denotando um sentido de corpo que tem como exemplo o campo da cisnormatividade ou, como Fernanda fala, pelo reconhecimento de uma presença corporal.

Esta segunda questão se desdobra em outra, que diz respeito às cirurgias de transgenitalização, também conhecidas como cirurgia de redesignação sexual. A passabilidade também parece perpassar o campo da reconstrução da genitália, sendo também indiciada pelos 
manuais de medicina. Só seria mulher ou homem de "verdade" ou, melhor dizendo, "transexual verdadeiro" aquela ou aquele que repudia sua genitália e requer a cirurgia como forma de afirmar o gênero (Butler, 2009, 2016; Oliveira, 2014). Questiono: até que ponto a busca pela passabilidade não ratifica o diagnóstico dos manuais de psiquiatria e, ainda, indica que as pessoas não-passáveis são "menos" mulher ou homem que outras e outros? Como, historicamente, a psicologia - e outras disciplinas do campo da saúde - também não (re)significou suas práticas em prol deste "pedido" legitimado pelas pessoas trans?

Tal questão me soa como sendo reflexo de uma discussão que nem esta pesquisa findará e nem os estudos conseguem abarcar porque, como falado, não seria possível eu, enquanto pesquisador homem, cis e gay indicar e falar $d a$ experiência de quem vive, cotidianamente, um corpo que não comporta uma identidade legítima. Passáveis ou não, estes corpos gritam pela emergência da urgência que indica uma questão simples, porém complexa: todas e todos nós temos direito ao pertencimento, mesmo que não nos seja atribuído no nascimento biológico.

No transitar da experiência de encontro com Fernanda, ficam evidentes estes modos e moldes que a pré-configuração de corpo, oriunda do discurso médico, é posta em evidência. No tocante à readequação dos corpos, a sua narrativa revela o sofrimento que a pessoa trans e a travesti passam pelo fato de não ter o corpo que conflui à sua identidade, a busca compulsória de readequar seus corpos por vias que muitas vezes não são confiáveis e, ainda, o despreparo dos profissionais de saúde em lidar com estes corpos que assumem vulnerabilidades a partir da busca pelo pertencimento de um corpo-existência.

Para a narradora, as equipes de saúde, em especial as que compõem o SUS, não estão preparadas para lidar com a população de travestis e transexuais, pontuando que

Nos tempos de hoje, eles falam esse tipo de coisa: “Ai... olha só... por que você aplicou isso? Vou
ter que amputar sua perna.”. Não fazem nenhum exame... Não examina, não faz uma radiografia,
ultrassonografia, não faz nada!... Não estão preparados pra nada!!! Porque se chega a travesti,
é logo HIV! "Vamos fazer [exame de] HIV, vamos fazer [exame de] Sífilis.”. Ela tem um silicone
no corpo. Que tal analisar como está o coração, como está o pulmão? Porque esse silicone está
correndo no corpo dessa pessoa! Essa pessoa pode ter essas complicações cardiacas e circulares,
não pode.

Nesse recorte, entram em xeque os próprios princípios do SUS, que preconizam a gratuidade, universalidade e integralidade dos serviços e ações em atenção à população (Brasil, 2015). O despreparo, narrado por Fernanda, traz os seguintes questionamentos: é possível afirmar que uma travesti ou pessoa trans, que chega a um serviço de saúde e não lhe é conferido o direito de assistência a um reparo decorrente de uma complicação, ser lida como "integrada" 
à sua saúde? É preciso estabelecer a criação de cursos específicos voltados ao atendimento da população T? Que tipo de especialidade médica daria conta das especificidades desta população? Como entender universalidade e integralidade de uma ação em saúde quando ela é direcionada para um órgão específico e ofusca a saúde em toda sua dimensão? Como pensar saúde, nesta configuração, destinada às travestilidades e transexualidades no âmbito da esfera pública e do pertencimento de seus corpos-territórios?

Para além do próprio dispositivo saúde que, sendo formulado a partir de uma ordem vertical, que universaliza as dimensões humanas, reverbera nas formas de cuidado a representação de corpos configurados a partir da mesma lógica (Fraga, Carvalho \& Gomes, 2013). Neste sentido, os profissionais de saúde ainda se veem no despreparo, pois suas formações parecem também não associarem estas experiências o cuidado no modo como destinam suas práticas.

Entretanto, as questões da população $\mathrm{T}$ já vêm sendo olhadas por alguns profissionais em determinadas instituições, ora por um olhar que recolhe a singularidade como fazendo parte do direito em existir, ora com o olhar instrumentalizador que patologiza, exclui e fragmenta. $\mathrm{Na}$ narrativa de Fernanda, encontra-se que nos serviços "Existe absurdos hoje, mas naquela época, eles não tinham nenhum constrangimento de fazer isso, porque não tinha aparelhos de Estado que punissem, que vigiassem, entendeu?", denotando que são eles próprios - os serviços de saúde - os reguladores, punidores e vigilantes dos corpos.

Tal vigilância é comunicada quando da fala de Fernanda sobre a necessidade de os profissionais de saúde e educação se aproximarem mais das questões que envolvem gênero e sexualidade. Em sua narrativa, começo a perceber que o afastamento, a recusa ou ausência desta população nos serviços se devem à estruturação cisnormativa que domina o saber científico. É evidente, óbvio, que a ciência é construída pela e na academia e que o saber que se constrói é sempre sobre e de algo que, muitas vezes, escapa do habitual e do comum (Ortega \& Zorzanelli, 2010, Melo, 2015).

No entanto, as perspectivas que as ciências vêm assumindo pouco estão destinadas à responsabilidade de um compromisso social, inclusive pouco direcionadas ao retorno a seus sujeitos pesquisados. Esta, inclusive, é uma das ressalvas dos comitês de ética instituídos pela comunidade acadêmica no que tange às pesquisas com seres humanos que, em sua maioria, não tinha um compromisso de caráter ético e político, vislumbrando-se apenas as inovações tecnológicas e nosólogicas do campo da saúde, especificamente.

Quando ainda fazia parte da equipe dos Centros de Cidadania LGBTI, acompanhei coletivos e grupos em casas de acolhida, especialmente aqueles e aquelas que se destinavam ao 
público de travestis e transexuais (população que, entre outras vulnerabilidades, se encontra muitas vezes em situação de rua). Algumas das travestis e mulheres transexuais (poucos homens trans procuravam as instituições, mesmo com a disseminação das informações de ações do Centro) já haviam passado por outras casas de acolhida. Todas elas falavam que era comum pessoas as procurarem nas instituições com o intuito de fazer pesquisa. Lembro que elas falavam que os profissionais responsáveis pela instituição pediam para que elas tomassem banho e se vestissem, pois seria dia de visita de algum outro profissional. "A gente parecia bicho que estava num zoológico, onde as pessoas iam lá nos ver e tirar fotos, quando nem se importavam com o que a gente vivia e, quando muito, iam apenas esta vez e nunca mais voltavam..." era uma fala recorrente entre o grupo que acompanhei.

Seriam estes motivos os responsáveis pela não-procura pelos serviços de saúde? Por que esta população não acessa os serviços básicos? Fernanda enfatiza que o conhecimento da academia ultrapassa o saber da ciência, adentrando espaços que nem mesmo ela - a ciência dá conta.

Hoje em dia, as meninas, elas não vão nem no hospital! Porque o saber que se constrói, dentro do grupo, é maior do que o externo... médico, enfermeira pode ter esse saber acadêmico, mas elas invadem até o saber acadêmico.

Que saber se sobrepõe ao outro?

A invasão do saber acadêmico poderia ser compreendida apenas como invasão se se justificasse que existe saber menor ou maior que outro. Ao refletir esta fala de Fernanda, fico pensando como seria possível, em saúde, pensar políticas públicas que se fundamentassem no próprio acontecer da experiência cotidiana da população que se agrega ao "saber científico", ou até da própria experiência de bombadeiras. Penso, inclusive, que uma ação que se destine nesta perspectiva não estaria "reduzindo danos", mas sim indo de encontro à própria construção da ciência, fundamentada pela lógica de que só existe ciência porque ela é construída coparticipativamente, entre humanos.

Mas,

No nosso pais, se você for LGBTI, você nem pode doar sangue! Começa por aí. Então assim... não tem muito o que falar e se desdobrar sobre isso. Você não pode doar sangue, como se você fosse soropositivo em potencial, que você tem sifilis, que você tem tudo! Que você é uma bomba!

A afirmação da sexualidade e da identidade de gênero entra como uma "bomba" no campo da saúde: corpos jogados, que ninguém sabe o que fazer e que se espera "explodir". Esta 
fala, emblemática de todo movimento LGBTI, me deixa envergonhado. Não entendo como um país tão rico em tecnologia e ciência ainda considera a população LGBTI como grupo de risco para HIV/AIDS e ISTs ${ }^{29}$, em geral. De fato, diversas vulnerabilidades são encontradas na trajetória de LGBTIs, mas ainda é desastrosa a lente que a saúde se permite utilizar, visualizando esta população como sendo um risco em potencial, ou como sendo pandêmico por natureza (Brasil, 2015).

A existência de pesquisas e programas que retificam as informações leigas do público em geral sobre questões de HIV/AIDS são, cada vez mais, propagadas na atualidade, porém são escondidas nos escombros da prática clínica de profissionais, que acabam ratificando o imaginário coletivo da comunidade. A fala de Fernanda expressa bem como a cis heteronormatividade apodera-se dos discursos divergentes, reverberando na prática cotidiana de profissionais de saúde. Como ela fala, a passabilidade lhe permite inserir-se em espaços que comungam com o modo cisnormativo de pensar e agir, assim como permite a uma pessoa cis e heterossexual, obviamente, usufruir das regalias de um serviço universal. Mas... universalidade para quem?

Nesta direção, os Centros de Cidadania LGBTI de São Paulo iniciaram uma série de sensibilizações na rede de saúde. Participavam profissionais de todas as áreas, iniciando pela atenção básica. O intuito destas sensibilizações é levar ao público de profissionais informações básicas sobre sexualidades, gêneros, orientações sexuais, direito ao nome social e civil, bem como modos de atender esta população. Chamo a atenção para os modos de atender esta população por entender que, como profissionais de saúde - aliás, como humanos -, o mínimo que se espera é que seja possível a mostração de relações humanas, sendo elas fundamentadas no respeito, ética e bem mútuo.

Como Fernanda conta, a criação do Programa Transcidadania ${ }^{30}$ em São Paulo possibilitou a travestis, mulheres transexuais e homens trans voltarem à escola, bem como favoreceu a circulação destas pessoas pelas cidades. Em sua narrativa, Fernanda situa o programa como sendo um acontecimento em sua vida, por ter trabalhado e construído estratégias e políticas

\footnotetext{
${ }^{29} \mathrm{O}$ termo IST refere-se às Infecções Sexualmente Transmissíveis, antes denominadas de DST.

${ }^{30}$ O Programa Transcidadania foi criado em 2015, na gestão do prefeito Fernando Haddad (PT), e estava situado na região central da cidade, sendo sedimentado pelas atividades dos Centros de Cidadania LGBTI. Trata-se de um projeto que visa à elevação escolar de travestis, mulheres transexuais e homens trans, além de favorecer no diálogo com setores que garantam a afirmatividade e efetividade de direitos básicos (como a moradia, a saúde, a educação, a assistência social e o trabalho). Em sua nova configuração, na então gestão do prefeito João Dória (PSDB), o Projeto Transcidadania foi descentralizado, sendo alocado em cada Centro (nas regiões Norte, Sul, Leste e Central). Com a descentralização, o projeto perdeu a configuração inicial, como o número de profissionais que acompanham os(as) beneficiários(as), redução de valor da bolsa destinada às/aos participantes, diminuição de vagas de inserção e a falta de investimento de verbas específicas para atividades, oficinas e cursos dentro e fora do projeto.
} 
afirmativas junto a esta população. Imagino como, tanto para Fernanda como para o(a)(s) beneficiários(as) do programa a iniciativa de um projeto como este pôde e pode reverberar em visibilidade e força para o movimento T. Era comum, durante minha curta estadia no Transcidadania, ouvir falas de meninas e meninos que diziam nunca ter ido antes ao centro da cidade, nunca ter pegado um ônibus e ir a um museu, nunca ter tido acesso a direitos fundamentais para pessoas - ações movimentadas com a inserção, pela participação e $n a$ coconstrução do programa.

Para Fernanda, a inauguração do Programa Transcidadania foi um acontecimento no município de São Paulo, abrindo possibilidade de a cidade ser tida como modelo no que tange às questões de programas voltados à população de travestis e pessoas trans. Segundo sua narrativa, o programa favoreceu a iniciativa de instituições e serviços a incorporarem travestis, mulheres transexuais e homens trans em seu quadro de funcionários, propiciando espaço não somente de existência desta população, mas de enfrentamento de vulnerabilidades cotidianas e de garantia de cidadania.

Em nosso encontro, Fernanda fala enfaticamente que o Transcidadania enfrenta diversas dificuldades atualmente, em sua nova configuração, motivo tal que reverbera um sentimento de tristeza e insatisfação. Diz que antes era possível ver a população trans e travesti nos serviços, ocupando a cidade e que hoje esta realidade está mudada. A parte em que ela diz "é pra pôr isso na tua tese" não representa somente uma fala de pedido vinda de Fernanda, mas sinto como um grito político que urge das entranhas, um posicionamento que re-clama por visibilidade, por atenção, cuidado e zelo. Como?

No momento de escolha da temática para pesquisa em minha tese, tendo como lente compreensiva a fenomenologia existencial, inquietei-me e disse "Não quero uma tese de filosofia, quero uma tese de psicologia.". Desse modo, em contato com grupos de travestis, mulheres transexuais e homens trans, tive mais clareza da dimensão política de nossas ações e atitudes enquanto psicólogos(as). Durante minha estadia nos Centros de Cidadania LGBTI, comecei a pensar nesta "nova" área de conhecimento dentro da própria psicologia, denominada de Psicologia Política. Questiono a precisão desse termo, ou melhor, dessa área de conhecimento, uma vez que compreendo que ser psicólogo incluiria necessariamente uma ação política. Do contrário, que tipo de psicologia fazemos e realizamos enquanto psicólogas e psicólogos? Será que nossas ações e intervenções não devem ser fundamentadas a partir da disposição política de nossa ação clínica?

Pensar política é também pensar relações humanas e cidadania (Butler, 2015). É compreender as pessoas "vistas na sua construção humana, na sua construção de formação 
educacional e não enquanto presença de ter que ficar nos espaços.", ou melhor, "é um acontecimento... é a dobra... é uma dobra que gera outras dobras na vida", com realce para uma perspectiva que vise ações conjuntas, que tenham sentido e destinação.

Uma semana antes do encontro com Fernanda, aconteceu um sério momento na história das travestis e mulheres transexuais de São Paulo. A Polícia Militar (PM) iniciou uma série de abordagens desumanas, desrespeitosas, antiéticas e sem fundamentos com profissionais do sexo que trabalham na Praça da República, na região central da cidade. Apoiada, obviamente, pela Secretaria de Segurança Púbica, o fundamento da PM era de "crime de vadiagem", um retorno à época da ditadura que nosso país vivenciou, revelando a participação do Estado na invisibilização, ou melhor, na criminalização de suas existências: “As coisas estão andando de ladeira a baixo.".

O movimento de travestis e mulheres transexuais, além dos movimentos que envolvem profissionais do sexo, entrou em ação na tentativa de requerer esclarecimentos junto aos poderes públicos municipais. Nove travestis foram detidas com a alegação de crime de vadiagem por simplesmente estarem em seus locais de trabalho. É importante falar que prostituição, no Brasil, não é ilegal. A ilegalidade, talvez, advém do Estado, que não direciona políticas públicas e não favorece espaços de possíveis construções de diálogos e ações a serem desenvolvidas em prol da cidadania desta população.

É ilegal o Estado, e nosso governo ilegítimo. O golpe de Estado que tivemos revela bem esta especificidade. O momento político atual, expresso na fala de Fernanda sobre o que dizem as beneficiárias do Transcidadania acerca da nova configuração do e das iniciativas voltadas ao projeto “Nossa, tá uó! Tá uó! Tá uó!”, revela que “quando elas dizem que 'tá uó', é que a coisa está horrorosa, porque elas sabem que elas não têm valor, que elas não têm espaço, que é uma farsa as atividades que elas frequentam no programa, que não serve pra nada!". Isso revela a necessidade de inauguração de políticas afirmativas e estratégias de cuidado compartilhado por esta população.

Tal configuração determina e dissemina atitudes que, do ponto de vista ético-político, soam como expulsão desta população dos espaços que lhes são destituídos de direito, como a escola e o acesso aos serviços de saúde. É importante destacar a fala de Fernanda, ao dizer que

No primeiro dia de aula dela [uma beneficiária do Transcidadania] na escola, a gente tinha que estar na escola. Por quê? Essa menina evadiu? Se a pessoa vem tacar fogo no meu corpo, na escola, eu estou tendo escolha? Não, porque se eu estou na escola, eu vou estar morta! Elas foram EXPULSAS da escola! Porque diretor não faz intervenção, coordenador pedagógico não faz intervenção, os pais não fazem intervenção, ninguém faz intervenção! Então não tem ninguém POR, entendeu? Não tem ninguém POR essa pessoa... Essa pessoa já não existe... 
Essa pessoa já não existe porque todos seus direitos lhes são tirados, inclusive seu direito de ter um nome. "Eu tenho nome. E quem não tem? Sem documento, eu não sou ninguém. Eu sou Maria! Eu sou João! Com certidão de nascimento, sou cidadão! ${ }^{31}$ " esta era uma fala de uma propaganda sobre certidão de nascimento e direito ao nome, veiculada na TV aberta. Desde muito, travestis, mulheres transexuais e homens trans lutam pelo reconhecimento de seu nome. Antes, o nome social, muitas vezes entendido como apelido ou pejorativamente "nome de guerra" pela população em geral, era a luta do movimento T para legitimar sua existência, pois "Nem todos tem nome nesse país, infelizmente. ${ }^{32 "}$.

Durante minha experiência com esta população no serviço público, fui convocado a realizar pareceres psicológicos para entrada na justiça de algumas e alguns beneficiários(as) do Transcidadania. No começo, questionava-me como realizar um parecer e por que seria minha função fazê-lo. Entendi, junto a outros psicólogos e psicólogas, que nosso papel para este tipo de documento seria o de escutar e recolher informações, uma maneira de autenticar o que elas e eles falavam de suas histórias.

Hoje, a luta da população T não é mais em prol do nome social, mas sim do nome civil, a retificação de seu nome compulsório para seu nome que lhe cabe, que lhe compete. Penso que, para isso, nem seria necessário um parecer de um profissional de psicologia ${ }^{33}$, uma vez que não cabe a mim legitimar uma existência que já está aí. No entanto, o impasse com a burocracia jurídica - espera de meses e até anos - depende da compreensão do(a) juiz(a) de direito, que é o responsável por dizer quem é "alguém" ou "cidadão/cidadã". Como ser cidadão/cidadã quando the tiram o direito de autonomia de exercer sua própria cidadania?

Corpos periféricos, subjazidos nos escombros, tangenciais, limitados, determinados, destituídos, fragmentados, descuidados, desimportantes, curiosos, inquietantes, ausentes, fantasmagóricos, escravizados, intrigantes, dóceis, (des)obedientes, criminalizados, vadios, putos, motivos de escárnio, piadas, sem peso, plastificados, das esquinas, encapsulados, dependentes, deselegantes, corpos-monstros, (des)temidos, vulgarizados, bagunçados, desprezados, desprezíveis, sofridos, porém resistentes. O encontro com Fernanda possibilitoume transitar por diversas nuances e especificidades do corpo trans, do corpo travesti, indicando

\footnotetext{
${ }^{31}$ Música disposta numa propaganda desenvolvida pelo Governo Brasileiro em parceria com o Fundo das Nações Unidas para a Infância, UNICEF (United Nations Children's Fund), de 2007.

32 Comentário de "Xena", na página virtual do Yahoo, sobre a propaganda em questão. Disponível em: https://br.answers.yahoo.com/question/index?qid=20110504054804AAigiSx

${ }^{33}$ A discutir posteriormente.
} 
que é preciso olhar para o "avesso do bordado" 34 , desvestir-nos de nossas próprias amarras, aproximando-nos de uma experiência que não conseguimos ter acesso senão pela imaginação, porque o nosso cruzamento não dá na esquina.

A tatuagem está feita. O Arlequim que sou deixou o café esfriar-e bebeu-o mesmo assim.

\section{2 "Como é dificil, pai, abrir a porta": o nascimento de Joyce na intimidade do quarto}

Marquei com Joyce o nosso encontro, que aconteceu no seu lugar de trabalho ${ }^{35}$. Fiquei pensando o quão o local desse encontro não poderia gerar atropelos, de um lado e, por outro, não poderia deixar-me um pouco com uma sensação de estar sendo intruso. A intrusão a que me refiro vem da ideia de que seu lugar de trabalho pedia não somente por sua presença inteira, que fazia Joyce ser a Joyce funcionária, mas pela imersão numa instituição que ali se transformava em lugar de encontro esmiuçado pela solicitude de um convite proposto - para alguém que não faz parte da instituição.

Ela leva-me ao primeiro andar do prédio, para uma sala onde ficam alguns documentos. Convida-me a sentar. Pergunto se posso gravar áudio de nosso encontro, ela responde sorridente “Claro, querido! Será um prazer!", e rimos. Agradeço por sua solicitude e falo um pouco sobre minha pesquisa, esclarecendo como penso em trabalhar nosso encontro e de que forma ele pode suscitar questões a serem pensadas para uma possível ação política na saúde de LGBTIs.

Joyce diz que posso perguntar o que quiser e que tentará falar todos os detalhes do que for preciso. Diz, logo de início (antes de gravarmos), que é travesti e que é importante denominar-se assim. Cabelos longos, pretos e lisos. Lembram-me os cabelos de Iemanjá. Rainha do mar. Rainha das águas. Desde as trajetórias antigas de diversas culturas, empreendeuse um sentido à água como sendo algo relacionado às emoções. No rio, as emoções que correm. No mar, as emoções que se deflagram em onda. Assim parecia-me Joyce: lugar de encontro entre rio e mar.

Assim, acontece nosso encontro.

Pesquisador - Gostaria que você falasse sobre sua experiência de ser travesti.

\footnotetext{
${ }^{34}$ Referência à música "O que eu não conheço", interpretada por Maria Bethânia e letra de Jorge Vecillo e J. Veloso.

${ }^{35}$ Para manter a confidencialidade da entrevistada, o nome da instituição de trabalho da mesma não será inserido no texto.
} 
Joyce - Eu lembro quando muito cedo, quando tinha mais ou menos meus dez... Quando eu era muito criança e que eu ainda nem tinha noção se era menino ou menina, eu achava que era igual a minhas irmãs e minhas primas, fazia tudo de menina. Chegou uma época na minha vida em que eu sabia que era diferente e que não era igual minha irmã, que eu era igual ao meu irmão. Mas eu achava que podia ser menina daquela forma também, disso eu tenho certeza que era desse jeito, eu lembrava. Eu tinha o quê? Eu tinha... beirando meus dez anos. Antes disso, eu não lembro muita coisa. Só lembro que meu pai judiava muito de mim, que minha mãe falava, que meu pai me pegava pelo pé, assim (demonstra com gestos) e me jogava na parede "Essa peste vai dar pra frango!". Isso, minha mãe disse que eu tinha de quatro para cinco anos de idade. Aí, eu vim lembrar, assim, desses dez anos já, que eu já tinha atitude de menina mesmo, só não vestia calcinha porque eu não podia, que minha mãe não deixava. Eu não virei assim “Ah, eu vou virar uma travesti.”. Eu NASCI uma travesti. Eu nunca fiz nada com menina, eu já nasci querendo menino. Ia às bananeiras com as minhas irmãs, pras bananeiras com seus namorados, com meus primos brincando de casinha... Todo mundo queria ser meu marido, porque minhas irmãs e minhas primas, tudo burras, iam fazer comidinha e faziam de areia, de pedrinhas e eu fazia com folha de jambo (ri)... que era bem azedinho. Aí, os meninos todos queriam ser meus maridos. Mas era só brincadeira de criança. Isso, nessa idade, de dez anos, de criança. Aí, pronto, com onze anos comecei a conhecer a safadeza, eu gostava, né? Já como menina e... beirando os doze, eu já estava me prostituindo... Tinha um vizinho meu que ele... eu ia pra casa dele e eu sabia que ele queria fazer safadeza comigo - porque naquela época a gente falava "safadeza" né - e eu ia, mas ia com aquela vontade de fazer safadeza com ele, mas ele era gentil, ele era mais velho. Eu ia atrás dele. Eu que ia atrás dele, não era ele que ia atrás de mim, era eu. E eu ficava, e estava com o pé assim, eu sentava e encostava no pé dele, quando eu tinha onze anos, quando eu tinha... depois dos meus dez, né? E eu ficava... eu queria que ele mexesse comigo. Eu queria. Não sei se criança pode sentir prazer sexual, mas eu sentia já uma vontade de menino, de homem... Com doze anos, eu já me prostituía. A gente era muito pobre, aí eu ia pra Cavaleiro, que era uma feira livre que tinha, ia buscar... pedir as coisas. Aí, os homens pegavam... achavam que eu era menina, mas sabiam... viam que eu era menino, né? Os homens, né? Aí, já queriam, né? Diziam “Vem mais tarde aqui que te dou tal coisa.” Aí, eu já sabia. Os homens mais velhos. Aí eu já ia com o maior prazer. Chegava lá e eles me pegavam, eu já deixava... Meus pais não sabiam. Do sexo, não. Minha mãe, às vezes, achava muito estranho, porque eu era uma das únicas... porque meus primos, minhas 
primas, todos iam pedir esmola e eu sempre chegava com mais coisa. Mas eu sempre fui uma pessoa bem articulada, né? Bem articulada! Eu sempre corria atrás das minhas coisas, nunca passei vontade na minha vida. Eu não vou dizer que a necessidade me ajudou a me levar para prostituição, nova, com meus doze anos. Porque eu me prostituía... tinha homem que chegava assim "Mas você aguenta? Você consegue?", de tão criança que eu era. Acho que... normal... a gente está cansado de ver nas reportagens, crianças e adolescentes nas esquinas, beira de rua, se prostituindo... tanto meninas, como meninos. E quando eu vejo isso, eu me espanto "Gente, ainda não mudou? Continua do mesmo jeito, oh!". Eu tinha necessidade, mas gostava também. Não vou dizer que eu não gostava. Eu gostava. Morava com meus pais ainda. Nunca cheguei pra minha mãe e disse " $A h$, mãe... eu sou menino, eu sou menina.". Nunca cheguei pra falar. Eu nasci e... me tornei! Me tornei mulher! (sorri). Eu não virei mulher. Eu nasci. Me tornei mulher. Em relação a sexo... teve uma época, na minha vida, até os meus dezoito anos, eu morria de vergonha de mostrar meu pênis. Eu vim gozar com quase dezesseis anos! Eu tinha vergonha! Eu vim gozar com quase dezesseis anos. Eu só dava, porque eu tinha vergonha de me tocar na frente dos caras... Na verdade, eu não lembro muito bem. Eles me tocavam... $\mathrm{Na}$ verdade, eu me escondia, né? Eu vestia calcinha com meus treze, catorze, quinze anos... mas eu só arriava a calcinha e deixava o bumbum, deixando a calcinha assim... tapando (demonstra com as mãos). Até os meus dezesseis anos, era desse jeito. Aí, a prostituição... A gente aprende os toques, a carícia, o desejo... Aí, a gente aprende a gostar do sexo e se aceitar, tá entendendo? Eu não tenho problema nenhum! Não tenho problema nenhum aqui! (toca na região genital) Não é o meu prato! Tá entendendo? Um homem mesmo... se ele quiser, ele estraga minha relação (pausa). Se eu tiver interessada por ele, ele estraga a relação. Pra mim, né!? Eu gosto de ser mulherzinha mesmo! Não rola pra mim, não!... Com catorze anos, eu tenho foto... eu com catorze anos, a Praia de Boa Viagem, de biquíni, com peitos de fora (gargalha). Tenho com doze... tomei hormônio da maneira que, normalmente, as meninas tomam por aí. Uma vai passando pra outra, uma aplica na outra... dessa forma, assim! Desse jeito. E até as farmácias. Tem muita farmácia que eles aplicam com a maior facilidade... Sabe que vai ganhar dinheiro, que é um cliente que vai estar ali sempre, então ele aplica certinho, né!?... Nunca fiz acompanhamento na minha vida. Eu me hormonizei, tomei hormônio dos meus treze até meus vinte anos de idade. Tive um peito imenso! Peitão mesmo! Do tamanho dessa prótese que tenho aqui. Aí, com os meus vinte e cinco anos, eu já coloquei minha prótese. Essa prótese minha aqui... ela... já tem quase vinte anos! Já passou, já está bem mais do que vencida, né!? Mas não está 
me incomodando. Ela só está dura, né!? Mas não me incomoda. Eu escutei um cirurgião plástico falar que a validade é de dez anos. Tá, tudo bem! Mas se ela estiver ali e não tiver te incomodando, não tiver doendo, pode ficar tranquilo. Pior é esse silicone líquido que as bichas colocam por aí... Tenho silicone industrial no corpo. Tenho! Tenho há... foi em noventa e oito... que eu coloquei. Seis litros. Coloquei no meu bumbum... Eu não sabia que poderia fazer acompanhamento médico, porque na minha época não existia isso. Impossível! Era impossível! Não existia isso não! Sem chance! Impossível! Uma menina da minha época... eu estou com quarenta e quatro anos. Há trinta anos, não existia, era impossível, esse lance de acompanhamento. Se existia, desconheço. Hoje não tomo mais hormônio, porque eu tomei, tem quatro anos que inventei de tomar por conta própria, pra minha prótese ficar mais bonita e passei muito mal. Fiquei com medo de tomar e não tomo não, e nem tenho interesse em tomar... Eu tive um AVC, fiquei internada. Fiquei quinze dias internada no Hospital da Restauração. Passei por constrangimento no hospital. Como eu moro aqui em São Paulo e fui pra Recife, eu... a gente capricha, a gente que é mulher, a gente capricha no corpo, no cabelo, na aparência. Então, eu estava muito bonita! Eu estava muito morena, muito bronzeada, o cabelo imenso, liso. Tive o AVC, me levaram, me socorreram. Os médicos me botaram na sala de homem. Acho que no tempo que passei lá, foram cinco neurologistas que passaram por mim. TODOS OS MÉDICOS QUE CHEGAVAM, PRA MIM, QUE ME OLHAVAM... porque primeiro que, como era muito quente dentro do hospital, não tinha como a gente ficar enrolada, então sempre estava com pouca roupa. Eu estava muito bronzeada, corpo todo liso, corpo de mulher, feminino. Então, todo médico que chegava, voltava e ia lá na enfermeira. Tipo assim, olhava pra mim e "Enfermeira!", aí a enfermeira ia e "Não, é ele mesmo! Aí, eu ficava lá toda torta. Era sempre tratada pelo meu nome de nascimento. Aí, eu ficava lá toda triste lá, aí falava... o nome estava lá né!? E eu estava numa humildade "Não, eu estou mal. Eu tenho que ficar quietinha.”. Dá até vontade de chorar (se emociona e chora um pouco). "Eu tenho que ficar quietinha, porque estou toda torta aqui. Se eu for exigir mais alguma coisa, pode ser que e eles não cuidem de mim e eu fique pior. Então vou ficar quieta, que vai ser bem melhor.". Aí eu fiquei, fiquei na minha. Fiquei quietinha. Graças a Deus, deu tudo certo. Todos os médicos, foram cinco que passaram... todos os cinco, chegavam, olhavam meu nome que estava na cama e ia lá. O nome que estava na cama era o do documento. Não tinha nome social. Eu preferi ficar quieta. Eu só queria ser atendida. Eu não quis lutar por nada. Eu só quis que eles me recebessem. É tanta martelada, tanta coisa que a gente passa, velho, no mundo, que é melhor você ficar quieta 
que você não ser atendida... Tive vários constrangimentos. Com esse AVC, tive sequelas. Aí, eu peguei dez sessões de acupuntura. Peguei e fiz cinco... sete... e fez muito bem mesmo pra minha cabeça, pra minha mente. Eu tinha acabado de perder minha mãe também, eu estava muito triste, com uma tristeza profunda. Aí eu peguei... uma médica maravilhosa. Ela fazia acupuntura em mim, bonitinho. As meninas que me atendiam, na recepção, sabia quem era eu, que eu era Joyce. Um certo dia, uma das meninas começou a me chamar pelo meu nome de documento e eu quieta, esperando ela PARAR de chamar meu nome para eu me levantar, pra ninguém perceber. Mas ela não parava de chamar. Ela chamou DEZ VEZES! Só o meu que ela chamou dez vezes. Porque, normalmente, ela chamava "Fulano de tal! Fulano de tal!" e já pulava pra outro. Eu, não. Eu, ela não pulou. Ela continuou a chamar. Aí, eu levantei e entrei. Aí ,quando entrei ela falou "Você é assim? Por que você não falou?", aí eu me descontrolei. Eu fiquei com tanta raiva, que me descontrolei. Comecei a falar alto com ela. Falava que era uma falta de respeito dela, que meu nome era Joyce, que ela estava errada de me tratar daquela forma. Aí ela pegou e falou assim “Ah, é? Então se você quer ser tratada assim, por que você não está vestida de saia?", aí eu falei (gritando) "É o quê, sua desgraçada? Você está de saia também? Você não está de calça?", aí saí e fui embora. Terminei a acupuntura e fiquei com vergonha de voltar e perdi dez sessões de acupuntura, cada uma de cem reais. Eu fiquei tão triste! Tão triste! E fiquei com vergonha! Até pelo meu descontrole. Não denunciei... Eu conheço o centro de cidadania... tem o quê?... tem (pausa) três anos. Então, tem três anos que eu vi... escuto falar em retificação de nome. Porque antigamente... eu não vou mentir. Eu sabia que existia, mas eu não sabia como faria, como que funciona. Porque é o desejo de todo mundo. Eu sabia que existia decreto, tanto que tenho o cartão do SUS... Por causa de nosso documento, o primeiro passo é você informar ao funcionário, né!? Porque se você não informar, você é tratada com o nome do documento. Então, você já tem que ir direto informar. Sempre fiz dessa forma. Sempre informei. Em todos lugares que chego, já vou logo informando. Há muitos anos! Há quinze anos... desde que eu me entendo por gente, que eu sei que pode ser usado o nome social. Não sabia da existência da retificação, não tinha noção, mas do nome social, eu sempre usei. Eu sempre informei às pessoas "Por gentileza, seria possivel, na hora de me chamar...". Primeiro porque eu trato doenças crônicas, né? Então, preciso muito de estar na rede de saúde. É impossível... vivo de um lugar pra outro... faz a gente ficar mais articulado, mais paciente com as pessoas... você chega humilde. Você tem que chegar bem humilde junto das pessoas que vão te atender, pras pessoas “Olha, como ela é educada! Como ela é humilde! Vou tratar 
ela assim mesmo!". Porque se você chegar um pouco arrogante, você corre o risco de passar vergonha... A última, foi aqui ao lado. Eu estava passando mal e fui ao médico. Uma recepcionista maravilhosa me atendeu. Eu disse "Por favor, você poderia me tratar com o nome social?" ela disse "Sim, lógico!". Ela preparou, abriu minha ficha como Joyce Felix da Silva e botou sexo feminino. O médico falou, quando cheguei no médico, o médico mais maravilhoso ainda! O médico me atendeu. Depois de mais ou menos dois meses, precisei de novo do posto e disse “Vou lá!”. Quem me atendeu já foi outra pessoa. Aí, eu falei “Joyce Felix da Silva!”, aí dei meu RG pra ela. Ela procurando, procurando... Aí, ela falou "Mas você falou... que tem ficha aberta aqui... não tem ficha aberta aqui.". Eu disse "Tem, sim, meu anjo! Já vim aqui, já passei no médico.”, e ela procurando. Eu disse "Será que não está com meu nome social? Porque meu nome social é Joyce." Aí ela “Joyce. Ah, está aqui!". Ela ficou HORRORIZADA com o que a menina tinha feito. Ela falou que era CRIME o que a menina tinha feito. Eu disse "Mas como é crime? Se você está dizendo que é errado e ela faz dessa forma, não é um erro de administração? Porque, da recepção, tenho certeza que não é." (pausa). “Tá bom!”. Eu estava tão doente, também, com a minha garganta com duas bolas de pus, preferi ficar quieta de novo e ela fazer do jeito que ela queria. Aí ela realmente... mudou todo o sistema deles lá, botou meu nome do documento, meu nome social... todo mundo me chamou pelo meu nome social. $\mathrm{Na}$ hora da coleta de sangue, a menina me chamou pelo meu nome de documento. TODO MUNDO olhou pra minha cara. Eu disse "Mas mulher...", ela disse "Desculpa, porque é exame, aí não pode..." não sei o quê... Aí, eu “Ok!". É tanto constrangimento que a gente passa nesse mundo. Então, quer dizer, é normal, né!? A gente passar por constrangimento. A gente está nos lugares, quietinha... porque eu uso muito o serviço de saúde. Muito, mesmo. Então, é normal chegar nos lugares e as pessoas continuarem do jeito que vai. Se for chamada pelo nome de documento, TODO MUNDO OLHA PRA TUA CARA!!! Tem funcionários que não fazem nem questão de tratar... Se eu viesse de novo, eu queria vir travesti de novo! Eu queria vir travesti de novo! Mesmo com todas dificuldades, eu queria vir travesti de novo! É sério, velho! Queria vir do mesmo jeito! Eu não tenho problema nenhum. Não me interessa o que tem nos outros não, me interessa o que tem dentro da minha cabeça. Eu gosto de me sentir fêmea. Eu gosto de ser cortejada. Homem, para me ter, ele tem que me cortejar (pausa), pra ele me ter. Prostituição é outra coisa! Mas um homem, pra ele me ter, tem que me cortejar! Não é assim, fácil não... Eu queria vir do meu jeito!... Mas, sempre, a gente passa constrangimento. É impossível! O "ELE”, né!? O "ELE” é muito constrangedor! Chega a dar RAIVA! Você está alii com seu cartão 
de crédito, você está ali com seu dinheiro e um funcionário, meu, que é instruído pra trabalhar, pra tratar os clientes bem... Aí, chega uma travesti, feminina, e ser tratada por “ele”... Na minha opinião, é falta de educação, é indelicado! Você está sendo indelicado com a travesti. Se ela quisesse ser tratada como "ele", ela estaria como um rapazinho, ela não estaria ali de menina. Se ela está de menina, é porque ela é menina. Ele não está vendo isso? Ali não é casa da mãe Joana! Eu já passei por “n” lugares. Já cheguei a fazer escândalo! (pausa) de derrubar as coisas “O QUÊ?” porque a pessoa não só tratou como "ELE", te tirou mesmo do sério! Então, quer dizer... é onde gera violência, onde gera confusão... é complicado! E tem gente que te trata com abuso, com tiração! E você não é obrigada! Você está com seu dinheiro no bolso, com seu cartão de crédito, você chegar num lugar pra comprar e ser tirada!? Por favor, né!?... Desde os meus doze anos que eu sou danada. Como a gente era muito sofrida, eu descobri que a gente, menina, a gente tem uma prioridade a mais que os meninos, até por a gente ser feminina. É menina, né!? Você passa fome, se você quiser. Você dorme na rua, se você quiser. Porque você é mulher! É só você saber se articular, saber viver. Sempre fui esperta. Sempre soube usar meu corpo. sempre valorizei minha prostituição. Nunca fui à toa. Sempre tive muita necessidade, mas eu era menina mesmo... Descobri que eu tinha um potinho de ouro comigo, então sempre usei isso a favor da minha sobrevivência. Até hoje, aos meus quarenta e cinco anos de idade! Eu trabalhei num restaurante, mas já trabalhei como Joyce, porque tinha uma travesti que era cozinheira... aí precisava de uma auxiliar de... de cozinha. Como eu tinha noção de salgados, em cortes de verduras, de legumes, fizeram um teste comigo e me chamaram. Foi um sucesso, porque a dona do restaurante não tinha problema nenhum com as meninas, com as travestis, e foi maravilhoso! Nunca tive problema nenhum! Mas também não deu certo, né, não durou muito tempo. Acho que consegui ficar mais de um ano lá e sempre voltei pra prostituição, porque a prostituição sempre estava ali, né!? Tem que sobreviver. Tem que pagar água, pagar luz, comprar roupa. Tem que arrumar o cabelo. É caro ser mulher! Ser travesti é mais caro ainda! Uma sobrancelha é quinze reais, uma unha... é mais caro justamente disso... em termo de se embelezar! Porque você não nasce bela! Você não nasce bonita! Muitas mulheres belas, aí, elas têm que ir no salão escovar os cabelos, tem que estar no salão arrumando sobrancelha! E isso vai fazer com qual dinheiro? (sorri). Então, é mais caro ainda pra travesti! Principalmente, quando tem aquele lance de pelo, aí é mais caro ainda pra fazer depilação, pra se sentir a pele mais lisa, de fêmea... é mais caro ainda pra ser travesti. Os seios, botar a prótese, botar o silicone. Tudo isso é mais caro! Quando digo mais caro, digo nesse sentido. (pausa). Não 
vamos ser hipócrita, né!? Ninguém vê, por aí, uma travesti do outro lado fazendo um cachorro quente ou um hambúrguer pra você. Você vê? Não vê! Muito raro! Fala aí pra mim! Não vê! Hoje em dia está mais fácil. Mas olha que época que a gente está! Já tem uma facilidade. Hoje conheço meninas que dizem “Ai, quero terminar o segundo grau. Quero fazer faculdade!”. Na minha época, não era isso, não! Na minha época era, “ $A i$, quero ir pra Europa! Quero ganhar dinheiro, ficar rica! Quero me prostituir!". Ninguém falava que queria terminar o segundo grau ou fazer uma faculdade. Hoje eu escuto isso das meninas. É maravilhoso escutar isso. Eu sinto orgulho. Eu sinto “Ah, evoluiu! Oh, está melhorando mesmo!" É do meu orgulho ouvir isso! Porque, na minha época, era impossível! Era difícil pra todo mundo, imagina pras meninas... O caminho era prostituição, mesmo! Se hoje é, na minha época era mais ainda! Na minha época, não se ouvia menina travesti falar "Ai, quero terminar a escola. Ai, quero fazer isso. Ai, quero fazer uma universidade." Não! Hoje eu escuto as meninas falando isso! Eu quero retificar meu nome porque já estou velha. Não sei o que pode acontecer, sabe? Não quero mais passar constrangimento, ter que ficar em quarto de homem e ser chamada de homem. É muito difícil.

De início, Joyce começa a falar de sua infância. Diz que nunca, nessa época, sabia uma distinção do que era "ser menino" e "ser menina", apesar de saber que, corporalmente, lembrava seu irmão, mas que, provavelmente, seria possível viver como sua irmã. Brincava das mesmas coisas com seus irmãos e primos, bem como com suas irmãs e primas. Em suas brincadeiras, aliás, em seu modo de ser criança, não parecia ficar clara a ponte que dividia um "menino" de uma "menina". A ponte que existia era o mundo adulto que vigiava algumas situações: que tipo de roupa deveria usar; a cueca que deveria vestir; o modo que tinha de falar, de um lado; e de outro, punia suas atitudes e comportamentos que não condiziam com sua genitália ou com o que parecia seu irmão.

“Eu não virei, assim 'Ah, eu vou virar uma travesti.' Eu NASCI uma travesti.". Esta fala de Joyce me leva pela mão. Desde a graduação, ouvia a tão estudada frase de Simone de Beauvoir (1908-1986): "Não se nasce mulher, torna-se mulher.", que perfaz um caminho importante no movimento feminista. O nascedouro trazido por Beauvoir, como para outras estudiosas de mesma linha de pensamento (Bento, 2006; Butler, 2009, 2015; Louro, 2015), indica que não é o sexo biológico ou a anatomia sexual que decidirá o "ser" da criança, ou melhor, o gênero da pessoa, mas as relações de troca que essa pessoa realiza e a que se destina na vida. 
Para Joyce, o "tornar-se" uma travesti não dava conta de sua experiência. Compreendo que, para ela, não era somente uma questão de relações políticas de troca ou de descentralizações de poder que destinavam o seu modo de ser Joyce, mas o seu próprio nascimento, assim como a Vênus ${ }^{36}$ de Botticelli. Então, assim como Butler (2015) postula “Como e onde ocorre a construção de gênero?" (p. 28), poderia ser uma questão a ser levada em consideração. Tornar-se uma travesti era causar o apagamento de seu nascedouro: a Joyce que estava à minha frente sempre existiu - nasceu.

Em meio às brincadeiras de criança, conta que parecia não existir, com tanto peso, essa diferenciação binária entre menino-menina. Vinda de uma família pobre, do interior de Pernambuco, aos onze anos inicia a vida sexual e, aos doze, endereça pela prostituição. Marcada pela "safadeza" 37 dos adultos, diz que sua prática sexual - infantil - pela prostituição era uma ação que fazia com muito prazer. Em nenhum momento da entrevista, Joyce fala que foi coagida, porém, ao entrar por entre sua narrativa de ser pobre e passar fome, questiono se o abuso sofrido (expresso como exploração sexual, uma vez que era criança) também não seria uma espécie de direcionamento para a vida adulta: vigiada pela "precisão" de ajudar aos seus pais, enfatizada pelos homens adultos e punida por estes mesmos homens através do sexo. Mas vou adiante na sua compreensão antes de expressar como posso compreendê-la.

Aqui questiono: Será que o fato de Joyce dizer que nasceu travesti não teria a ver com o fato de iniciar sua vida sexual, desde criança, "Já como menina" e de ser este o único modo (possível) de sua existência ser legitimada entre os homens? O que quero dizer com isto não é que seu modo de ser travesti estaria agregado ao "ser pobre", à "prostituição" ou ao "prazer de criança”, mas possivelmente firmado na própria experiência e presença de seu corpo em ser visto, tocado, conhecido, provado e autenticado por outros como travesti, e não como mulher ou homem.

Sigo embebecido por sua narrativa que, de certo modo, causa-me espanto. Escutei, anteriormente, de inúmeras travestis e mulheres transexuais ${ }^{38}$, que a iniciação pela prostituição é uma alternativa assinalada muito cedo, sendo, em sua maioria, pessoas advindas do contexto de pobreza e do Nordeste. Contudo, ainda assim, a fala de Joyce causa-me angústia:

\footnotetext{
${ }^{36}$ Trata-se da pintura "O nascimento de Vênus", de Sandro Botticelli. Pintada em 1483, a obra amostra a deusa Vênus emergindo do mar, sobre uma concha. Atualmente, está exposta na Galleria degli Uffizi, em Florença, Itália. ${ }^{37}$ Safadeza, em culturas do interior do nordeste brasileiro, relaciona-se a "fazer sexo" ou ao próprio órgão genital. ${ }^{38}$ Em minha prática como psicólogo e pesquisador, não escutei o mesmo tipo de experiência de trabalho (prostituição) com homens trans. Há de questionar se a prática da prostituição, no Brasil, também é uma realidade "prematura" para homens como é para as mulheres, sendo, muitas vezes, camuflagem do abuso sexual infantil, (especialmente no caso de travestis e mulheres transexuais) - iniciado entre a infância e adolescência.
} 
Porque eu me prostituía... tinha homem que chegava assim 'Mas você aguenta? Você consegue?' de tão criança que eu era. [...] Eu tinha necessidade, mas gostava também. Não vou dizer que eu não gostava. Eu gostava.

Angustia escutar que sua iniciação sexual deu-se na infância. Angustia escutar que era uma das maneiras de obter alimento para sua família. Angustia escutar que seus pais não sabiam, mas que os "homens lá fora" sabiam e pediam. Por entre os crivos da escuta, isso me causa angústia porque não consigo imaginar, mesmo estando "[...] cansado de ver nas reportagens, crianças e adolescentes nas esquinas, beira de rua, se prostituindo.".

Por vezes, o sorriso no rosto de Joyce, ao falar que sentia prazer de procurar por estes homens adultos, faz-me voltar aos estudos da sexualidade que perfazem o perfil de graduação em psicologia, inaugurados pela psicanálise, ao falarem sobre o prazer infantil. Aos tempos de Freud, falar de uma possível sexualidade infantil era um tanto como motivo de afronta, por este campo ser sempre um lugar de lutas de poder, aprisionamento e posse, como assinala Foucault (2017).

Porém, mesmo com o sorriso estampado de Joyce, seus cabelos de Iemanjá e seu nascimento como Vênus, questiono: por que é imprescindível pensar a travestilidade atrelada à uma sexualidade dos destroços, feita na surdina, enveredada pelos segredos, porém sempre circundada aos prazeres da carne para a mesma sociedade que lhes recriminam?

Foucault (2017) dirá que a sexualidade, no decorrer da História, nunca foi voltada aos escombros, mas sempre permissiva a detalhar-se por entre as instituições de vigilância, em especial ao Estado e à Igreja. Das confissões e prisões de um corpo andrógino, que muitas vezes relaciona-se à corporalidade travesti - mulher com seios e pênis -, fica evidente certa amorfia no que diz respeito ao modo como nós, pessoas cisgêneras, poderíamos evidenciar e até mesmo autenticar estes corpos. Pela estranheza que assola, a partir de uma trajetória cultural demarcada pela binariedade de corpos, entendo que o "visto", o "tocado", o "conhecido" e o "provado" não é autenticado por outros.

Seguindo pela narrativa de Joyce, ao falar sobre sua experiência sexual, encontro um momento no qual ela percebe que seu pênis não lhe é um objeto de prazer:

Na verdade eu não lembro muito bem. Eles me tocavam... na verdade, eu me escondia né. Eu vestia calcinha com meus treze, catorze, quinze anos... mas eu só arriava a calcinha e deixava o bumbum, deixando a calcinha assim... tapando (demonstra com as mãos).

Atentando à sua narrativa, poderia questionar a maneira psicopatológica, psiquiátrica e psicanalítica tradicional acerca do "ódio ao pênis", encontrada na pesquisa de Galli e Vieira 
(2013), que faz um recorte de como profissionais psis muitas vezes delegam à genitália mais um binarismo: amor-ódio.

Seguindo tal pensamento binário, à pessoa que odeia seu órgão genital, caberia a verdadeira autenticação da transexualidade. À pessoa que se sente como do gênero oposto ao órgão sexual, mas que não o repudia, caberia a travestilidade. No entanto, o já citado Movimento de Travestis e Transexuais, além das inúmeras pesquisas que empreendem às corporalidades e generidades no campo da saúde (Brasil, 2015), levantam a questão, sinalizando categoricamente que não é o órgão genital (nem o sentimento de amor ou ódio) que definirá uma identidade de gênero, nem muito menos a finalidade sexual deste.

Destarte, a mesma confabulação existente no campo da saúde, em especial no campo da medicina, também solavanca uma "descoberta da veracidade de um corpo" na psicologia. Algumas concepções da psicologia nesses serviços, em especial nos que se atentam ao processo transexualizador no SUS, servem como "reparadoras" ou "apontadoras" de uma patologia para fechar um diagnóstico e, enfim, autorizar novos cuidados técnicos por parte do saber médico para se proceder com a cirurgia de transgenitalização ou o início da hormonização (Brasil, 2015; Galli \& Vieira, 2013).

Bento (2006) pontua que "O olhar do especialista [leia-se o/a profissional de saúde], com suas técnicas de escuta, classificação e registro, substitui o padre, o juiz ou os tribunais populares, os quais eram os responsáveis por avaliar as condutas dos chamados gêneros fraudulentos." (p. 111). Esta análise presentifica como as travestilidades e as transexualidades ainda são massificadas pela questão diagnóstica que "descobre" o(a) "trans de verdade" e que prescreve o laudo que autoriza a intervenção no corpo alheio, no caso da psicologia.

Nesse sentido, fica claro que o papel da psicologia nesses serviços, de acordo com os estudos citados, vem perpassando o lugar de preenchimento de laudos técnicos a partir de discursos legitimados em ideais de corpos como substância, matéria e dignos de mensuração. Parece haver um retorno do corpo: voltam ao lugar de estranhamento, ofuscados e marginalizados, um espaço que é objeto de escrutinação a partir de um saber "que vem de fora" e dá um parecer sobre se esse corpo é legítimo ou não.

Conceber o corpo trans a partir desta lente que o massifica e lhe tira autonomia é desfazer sonhos, projetos de vida e, ainda, não acompanhar atentamente estes corpos. Até onde, nós, profissionais da saúde, temos esta responsabilidade? Aliás, será que nós assumimos esta responsabilidade de escrutinação do corpo do(a) outro(a)? O “saber psicológico", por exemplo, 
é um dispositivo ${ }^{39}$ para se verificar, quantificar uma verdade e confirmar uma experiência que é do(a) outro(a)?

Seria possível, amparado pelo trecho anterior da narrativa de Joyce e a partir do que foi empreendido posteriormente, elucubrar pelo mesmo pensamento binário de algumas posições do "mundo psi". Ou seja, deflagrando certo "repúdio" de Joyce pelo seu pênis, no entanto, ela fala:

Eu não tenho problema nenhum! Não tenho problema nenhum aqui! (toca na região genital) Não é o meu prato! Tá entendendo? Um homem mesmo... se ele quiser [seu pênis], ele estraga minha relação. (pausa) Pra mim, né!? Eu gosto de ser mulherzinha, mesmo!

Entre penetrar e ser penetrada, parece existir outra relação que escapa do campo simplesmente anatômico ou do desejo sexual: ter um falo e usá-lo para penetrar não (des)caracteriza a masculinidade do outro, mas, em sua experiência, permite com que sua feminilidade seja testemunhada, "cortejada".

Entre ser penetrada(o) ou penetrar, os campos das masculinidades e feminilidades entram em voga porque é necessário questionar-se que "modos" masculinos e femininos podem estar dispostos nos repertórios performáticos de mulheres, homens, travestis ou outras atestações de gênero. É necessário, ainda, questionar o campo do poder, no qual a lógica do "macho" contrapõe-se e sobrepõe-se à "fêmea", direcionando certas atitudes heteronormativas como a lógica universal e atemporal (Carvalho, 2014).

Assim, é possível ser e sentir-se masculino, mesmo sendo penetrado, bem como é possível ser e sentir-se feminina penetrando. O campo da heteronormatividade é escorregadio, porque de um lado presume esta configuração calcada no ideal do falo, fundamentada na lógica do poder do "forte" sobre o "fraco"; e, de outro, reverbera como ratificação de modos de viver e comportamentos esperados, com a atestação de que só é possível existir relações humanas quaisquer que sejam - se elas forem estratificadas e baseadas neste mesmo discurso censurador.

Talvez, amparada pelo discurso cartesiano e analítico que fundamenta a prática médica, o campo da saúde não consiga capturar estas especificidades e, por isso, acaba rechaçando a experiência em detrimento do crivo científico. Mas, ainda amparado pelo mesmo discurso, questiono se não seria através e por estas masculinidades e feminilidades entrarem em cena que seria possível nascerem modos de ser "homem", de ser "mulher" ou de ser "travesti". Como escreve Butler (2015), “é o estranho, o incoerente, o que está 'fora' da lei, que nos dá uma

\footnotetext{
${ }^{39}$ Entendido como um conjunto que compreende discursos, decisões regulamentárias, proposições filosóficas e morais que pertencem à esfera do dito, não-dito, instituição e instituído (Foucault, 2017).
} 
maneira de compreender o mundo inquestionado da categorização sexual como um mundo construído, e que certamente poderia ser construído diferentemente.” (p. 191).

Tais modos de "ser" são levados em consideração quando da necessidade de firmar no corpo a marca da identidade/quem sou. Para isto, travestis também recorrem à automedicação como mote fundamental na aquisição de uma presença feminina que seja testemunhada no corpo e autenticada pelo seu modo próprio de ser travesti. Sobre isto, Joyce fala:

Nunca fiz acompanhamento [médico] na minha vida. Eu me hormonizei, tomei hormônio dos meus treze até meus vinte anos de idade. Tive um peito imenso! Peitão mesmo! Do tamanho dessa prótese que tenho aqui.

A constituição de um "seio feminino" farto, muitas vezes representa, para algumas travestis e mulheres transexuais, a demarcação da feminilidade. Notoriamente, o corpo biológico age de maneiras diferentes para cada pessoa. Não seria diferente com fármacos que agem no corpo, especialmente quando se trata de hormônios, por estarem disponíveis no mercado apenas para reposição hormonal após a meia-idade ${ }^{40}$.

Ao que parece, muitas travestis e mulheres transexuais, ao não alcançarem seios como lhes foram imaginados com a hormonização, recorrem a cirurgias de próteses mamárias - em sua maioria adquirida em instituições de saúde e consultórios particulares. Joyce conta que colocou próteses nos seios aos vinte e cinco anos de idade, atestando que

ela... já tem quase vinte anos! Já passou, já está bem mais do que vencida, né!? Mas não está me incomodando. Ela só está dura, né!? Mas não me incomoda. Eu escutei um cirurgião plástico falar que a validade é de dez anos. Tá, tudo bem! Mas se ela estiver ali e não tiver te incomodando, não tiver doendo, pode ficar tranquilo. ${ }^{41}$

Estaria Joyce, de certo modo, desvelando um descuido em torno de sua saúde, mesmo demarcando a existência de próteses fora do prazo de validade em seu corpo?

\footnotetext{
${ }^{40}$ Leia-se para mulheres de meia-idade. A indústria farmacêutica pouco se atenta à reposição hormonal "masculina" e fármacos que se relacionem a métodos contraceptivos de uso para homens. Os hormônios "masculinos" - especialmente a testosterona - não são de aquisição livre em farmácias, necessitando de uma guia médica, enquanto os hormônios "femininos" - estrogênio e progesterona - são comercializados e adquiridos livremente (e inclusive aplicados no próprio local do comércio). Esta comercialização livre como atributo para a "feminilidade" talvez pressuponha um investimento dotado nas concepções de vigilância do corpo e punição pela própria perda de uma "condição feminina". Por outro lado, a docilidade de seus corpos é guiada e (des)vestida, sendo estes deflagrados pela imposição do que é "ser mulher de verdade", tornando-as vítimas da mercantilização da saúde - que deveria ser - pública.

${ }^{41}$ Aqui, recordo de Gadamer (2011), ao falar que a saúde "pertence ao milagre do esquecimento".
} 
Pior é esse silicone líquido que as bichas colocam [nos seios] por aí... Tenho silicone industrial no corpo. Tenho! Tenho há... foi em noventa e oito... que eu coloquei. Seis litros. Coloquei no meu bumbum.

O uso de silicone industrial, segundo Brasil (2015), é uma prática comum na trajetória de travestis e mulheres transexuais, especialmente aquelas que têm pouco poder financeiro, muitas vezes, é disseminado por todo o corpo. Rosto, seios, quadris e coxas são os principais locais de aplicação de silicone industrial, o que pode acarretar sérios riscos à saúde, especialmente se relacionadas a áreas que recebem maior vascularização no corpo ou áreas mais extremas ${ }^{42}$.

Para a narradora, todo percurso de injeção de silicone líquido e hormonização foi realizado sem acompanhamento médico. No primeiro caso, não é comum que injeções de silicone estejam associadas à prática médica, sendo muitas vezes realizadas em lugares com pouco preparo e higiene precária, quando não na própria residência da pessoa que está passando pelo procedimento.

Ainda que o Conselho Federal de Medicina não destine esse tipo de intervenção como sendo uma prática em saúde, é importante destacar que a Portaria do Processo Transexualizador do SUS incorpora o cuidado integral a pessoas que venham a ter complicações médicas decorrentes do uso da substância (Brasil, 2015). No segundo caso - a hormonização - a prática está mais associada ao comércio farmacêutico ou ao mercado periférico realizado entre grupos específicos. A prática "legalmente aceita" pelas instituições de saúde - ou melhor, pelos profissionais dessas instituições - é demarcada pelo acompanhamento clínico de nuances específicas em torno da saúde da pessoa. Vale destacar que o próprio processo transexualizador também acarreta ações em torno de complicações decorrentes do uso irregular de hormônios, o que muitas vezes é incompreendido pelos profissionais que atuam neste campo.

Sobre isto, no I Encontro Nacional de Saúde Trans ${ }^{43}$, que aconteceu em São Paulo, em novembro de 2017, ocorreu um marco histórico. No momento, presentes os principais responsáveis pelo setor de Psiquiatria do Hospital das Clínicas da Faculdade de Medicina da Universidade de São Paulo (HC-FCM/USP) - responsáveis pelo Processo Transexualizador na

\footnotetext{
${ }^{42}$ Como o silicone industrial é líquido, costuma sair do lugar injetado. Se colocado nas coxas ou bumbum e não sendo respeitados os limites do corpo orgânico, anatomia da pessoa, cuidados de higiene e repouso necessário, pode transitar e alocar-se para pernas e pés, acarretando doenças vasculares e até mesmo amputação.

${ }^{43}$ Apesar de ser nomeado como "I Encontro Nacional de Saúde Trans", o encontro não foi o primeiro a ser realizado com o intuito de discussão nacional no país. A mesa de abertura, com a fala de Tatiana Lionço (UnB), foi clara e categórica ao falar que em outra oportunidade foi discutida a questão da travestilidade e transexualidade no SUS. No entanto, este primeiro encontro parece não ter gerado tanto impacto nos serviços especializados, bem como nos órgãos que fundamentam e garantem os direitos previstos em portarias específicas no campo da saúde integral a travestis e pessoas trans. Assim, pretendo, num segundo momento, dedicar um capítulo da tese para este encontro, por entender que as especificidades das discussões oriundas do momento deram abertura para questionar o sistema político, administrativo e gerenciador em torno da saúde pública para esta população.
} 
instituição -, representantes do Movimento de Travestis e Pessoas Trans, profissionais de saúde de várias áreas de conhecimento e sociedade civil, abriu-se um espaço para discussão da Portaria do Processo Transexualizador, que preza também pelo atendimento integral às travestis que necessitarem do serviço. O motivo da discussão apontou como falho o sistema do HCFCM/USP, por não atender a travestis no serviço, entendendo a lógica do cuidado hospitalar como fundamentalmente voltada a questões de cirurgia de redesignação sexual, bem como de outros órgãos para buscar feminilização ou masculinização corpórea.

Ao que parece, esta atitude de desnivelamento de atendimento responde a uma demanda fundamentada na higienização de corpos, ou seja, todo investimento do hospital voltado a esta especificidade dirige-se ao "verdadeiro" ou à "verdadeira" trans de verdade (Bento, 2006; Butler, 2009; Oliveira, 2014), como forma de legitimar a existência desta população, mas que nega as corporalidades travestis por não estarem dirigidas necessariamente a uma reparação cirúrgica "transformadora" de mulheres e homens, como aponta Joyce, ao falar "Tive o AVC, me levaram, me socorreram. Os médicos me botaram na sala de homem.".

Tal atestação - a da veracidade de gênero - retorna à ideia de que a partir de uma cirurgia que atesta a genitalidade em conformidade ao gênero, é possível que esta pessoa possa sentirse "completa" em relação ao seu corpo. Tal pensamento (higienista e cisheteronormativo, de natureza) torna a prática das cirurgias como compulsórias (Butler, 2009), por entender que é ela que possibilitará à pessoa tornar-se corporal, física, mental, social e psiquicamente saudável, atestando a condição de uma existência firme e cidadã ${ }^{44}$.

O exercício da cidadania de pessoas trans e travestis é violado pelas próprias instituições de saúde, que não atentam para nuances do cotidiano da população T. A exemplo disto, o marco do nome social como primazia da reverberação de um direito conquistado por esta população é, muitas vezes, negado em diversos âmbitos no campo da saúde (Brasil, 2015), como Joyce também conta em nosso encontro, ao falar que

todo médico que chegava, voltava e ia lá na enfermeira. Tipo assim, olhava pra mim e 'Enfermeira!' ai a enfermeira ia e 'Não, é ele mesmo!' Ai eu ficava lá toda torta. Era sempre tratada pelo meu nome de nascimento.

\footnotetext{
${ }^{44}$ Inclusive, como aponta Ventura (2010), a alteração de nome civil em certidões de nascimento e demais documentos de travestis e pessoas trans, no Brasil, era feita somente quando da necessidade e obrigatoriedade da cirurgia de redesignação sexual, sendo esta a responsável pela legitimação atestada em perícia médico-jurídica especializada. Hoje, travestis, mulheres transexuais e homens trans podem, em diversos estados do país, retificar seu nome civil nos documentos sem necessariamente terem realizado estas cirurgias "reparadoras", ficando a título de leitura compreensiva do juizado no qual o processo jurídico foi instalado.
} 
Aqui fica evidente o descaso, negligência, desrespeito e destituição de direito que Joyce passou ao necessitar de uma instituição pública de saúde, bem como quando necessitou do serviço privado para realizar sessões de acupuntura. Vou adiante com sua historiobiografia...

Eu tenho que ficar quietinha, porque estou toda torta aqui. Se eu for exigir mais alguma coisa, pode ser que eles não cuidem de mim e eu fique pior. Então, vou ficar quieta, que vai ser bem melhor. Aí, eu fiquei, fiquei na minha.

Não é incomum, tal como vimos na narrativa de Joyce, que pessoas transexuais e travestis sofram este tipo de violação em instituições (especialmente nas de saúde e educação), ficando à mercê da "boa vontade" e "compaixão" de profissionais que estejam "mais abertos" à diversidade e da paciência e anulação da própria pessoa que necessita da intervenção destes serviços, gerando pensamentos que confluem com o da narradora.

Estes corpos “diferentes”, compreendidos por Butler (2002) como “corpos abjetos”, são corpos que "não importam", são corpos que não têm uma existência legítima, ofuscados por um pedido de materializar-se. São corpos periféricos, que vivem à margem pela categoria imposta. É nesse sentido que o corpo enquanto esta disposição no mundo, para a autora, é também compreendido em torno das performances de gênero (Butler, 2015).

Dá até vontade de chorar (se emociona e chora um pouco).... Eu não quis lutar por nada. Eu só quis que eles me recebessem. É tanta martelada, tanta coisa que a gente passa, velho, no mundo, que é melhor você ficar quieta, que você não ser atendida. Tive vários constrangimentos.

O direito de Joyce, assim como de milhares de travestis, é negado diariamente em diversas circunstâncias. A recusa pelo respeito ao nome social em instituições, muitas vezes, acaba sendo relacionada à burocracia do "sistema" por parte de profissionais, esquecendo que ela - mesmo que interligada à hierarquia e à morosidade de tarefas - pode resultar numa prática moral e perversa.

Destarte, o corpo da travesti parece ser um corpo que não respeita nem aos ideais de um corpo "natural-biológico", nem à anatomia, nem aos ideais sociais ou religiosos. Estes corpos são corpos em transformações, corpos mutantes (Galli \& Vieira, 2013) por reverberarem como corpos diferentes da norma, do que se compreende como um corpo feminino ou um corpo masculino. Nesta perspectiva de corpo, as performances variadas sinalizam que ele escapa de uma explicação causal ou referência de sustentação.

Para Butler (2009, 2015) e Miskolci (2013), estes corpos são compreendidos como queer. Queer é um termo inglês que foi utilizado pejorativamente, no passado, para tratar de 
homossexuais, porém o termo queer também tem o sentido de "estranho", "desnatural" e revela uma aproximação com o corpo trans. ${ }^{45}$

A partir deste termo, os autores constroem uma perspectiva de "Teoria Queer", compreendida como um espaço político que incorpora práticas discursivas de transgressões de uma heterossexualidade compulsória, um rompimento com um modo de pensar cisheteronormativo. Para Carvalho (2014), o surgimento do que se compreende por queer parte de uma luta que acontece em detrimento da consideração do corpo, desejo e sexualidade como campos que expressam relações de poder. Este contexto está atrelado à subversão e a não conformidade com compreensões metafísicas para o corpo, que atrelam ao mesmo um lugar de passividade e massificação em contraponto ao que ainda é observado, na contemporaneidade, acerca da relutância de aceitar este lugar que gera estranheza, no sentido "negativo" do que se compreende por queer.

Em detrimento de uma sociedade que sinalizava o caráter excludente das diferenças, a Teoria Queer - que nasce a partir de três movimentos sociais bem definidos nos Estados Unidos da América, a saber, os direitos civis, o movimento feminista e o movimento homossexual - ao visar uma nova perspectiva de corpo e, ao mesmo tempo, um novo horizonte político, demanda um lugar de repensar não somente a homossexualidade ou "grupos" encapsulados em categorias em torno da sexualidade, mas principalmente de toda e qualquer forma de abjeção (Miskolci, 2013). Tal caráter enfatiza a necessidade de deslocar as questões de gênero - algo construído e performado - das questões biológicas focalizadas no sexo, na genitália enquanto "centro" do desejo, sexualidade e afeto (Butler, 2015).

Na mesma direção, “a sexualidade é, na verdade, 'uma construção social', uma invenção histórica, a qual, naturalmente, tem base nas possibilidades do corpo: o sentido e o peso que lhe atribuímos são, entretanto, modelados em situações sociais concretas.” (Weeks, 2015, p. 40, aspas do autor). Neste cenário, o corpo trans aparece, desaparece e parece, ao não "se encaixar" no modelo anátomo-normativo, ao colocar em questão a sexualidade, o gênero, a biologia e o próprio corpo.

Seguindo pela entrevista com Joyce,

Ela [a recepcionista] ficou HORRORIZADA com o que a menina tinha feito [colocado o nome social de Joyce no prontuário de atendimento da UBS]. Ela falou que era CRIME o que a menina tinha feito. Eu disse 'Mas como é crime? Se você está dizendo que é errado e ela faz dessa forma,

\footnotetext{
${ }^{45}$ Em aproximação com o corpo "estranho" e "sem forma", destaco Serres (1993), ao falar do Arlequim, do canhoto e do mestiço como fazendo parte de uma mesma confabulação de corpo: o estatuto da norma como consolidação de um ideal que afasta, caracterizando "o não lugar, sim, o alargamento, portanto a liberdade ou, melhor ainda, o desaprumo, esta condição constrangedora e soberana da condução à verdade.” (p. 20).
} 
não é um erro de administração? Porque da recepção tenho certeza que não é.' [...] Aí, ela realmente... mudou todo o sistema deles lá, botou meu nome do documento, meu nome social... todo mundo me chamou pelo meu nome social. Na hora da coleta de sangue, a menina me chamou pelo meu nome de documento. TODO MUNDO olhou pra minha cara. [...] Se for chamada pelo nome de documento, TODO MUNDO OLHA PRA TUA CARA!!! Tem funcionários que não fazem nem questão de tratar.

Neste fragmento, evidencia-se que a prática em saúde preza pelo respeito ao protocolo, instrumentos de coleta e centralização do poder, sem questionar a norma hegemônica focada num saber-fazer que escapa à atitude reflexiva de quem endereça tal prática (Fraga, Carvalho \& Gomes, 2013; Morato, 2018). Este recorte reverbera práticas privativas em torno do corpo e mais ainda, da ética da responsabilização da pessoa (Butler, 2017) - possibilitando ofuscamento do exercício da cidadania, além de sinalizar que seu corpo é arraigado ao próprio sistema privativo; logo, nunca será de sua posse por completo.

Além do mais, tais práticas de caráter vertical delimitam a possibilidade de ações, uma vez que não se constituem acossadas via experiência do(a) usuário(a) do serviço, descentralizando e terceirizando ações interventivas e noticiando a emergência da urgência da revisão de um conceito de saúde ${ }^{46}$, que não consegue ser fundamentado e nem muito menos assertivo no cotidiano de pessoas que necessitam do Estado para este tipo de cuidado.

O despojo de um corpo, guardado aos confins de uma necessidade de cerceamento por outrem, diz de uma violência res-guardada que não só fere, mas que reverbera como assertiva, ao tentar fundamentar-se pela lógica do juízo de valor e saber deste outro. Se o corpo do outro não é dele, logo posso usufruir do poder sobre o outro e dele fundar o que, em torno de minha compreensão de humanidade e de mundo, julgo como necessária para uma vida ética e justa.

Destarte, a inferência de posse de um corpo em detrimento da possibilidade de aceitação e coparticipação em comunidade ao que este outro revela em sua existência deflagra-se em direção a um cárcere privado da própria existência, que é revelada em meio a pessoas.

Por causa de nosso documento [sem o nome retificado], o primeiro passo é você informar ao funcionário, né!? Porque se você não informar, você é tratada com o nome do documento. Então, você já tem que ir direto informar.

\footnotetext{
${ }^{46}$ Parafraseando Morato (2018), a saúde como conceito utilizado do Estado aproxima-se de uma compreensão tecnicista focada num "estado" do sujeito, ou seja, um atestado do Estado sobre um estado, perseverando uma visão positivista. No entanto, esta compreensão não se afina às experiências dos sujeitos que a própria saúde tem como objeto, passando a ser entendida como um modo de pertencimento ao âmbito da ética do humano, acossada à sua existência e implicação com suas relações-no-mundo. É por esta via compreensiva que este estudo caminha, por entender que o cuidado solicitado nas entrevistas segue pelos caminhos de um entendimento da saúde como uma "saudação", revelada pelo com-partilhamento de experiências.
} 
Sem o nome que, em sua condição, é um dos sinalizadores da singularidade humana e exercício de uma cidadania (Ventura, 2010), toda a constituição da pessoa que procura por uma atenção é desamparada e destituída de sentido. Sinto isto quando da fala de Joyce sobre a confusão que as pessoas fazem em torno do pronome de tratamento "ele" ou "ela", subjugados em torno do sexo biológico da pessoa e do nome civil estagnado em documento:

$O$ 'ELE', né!? O 'ELE' é muito constrangedor! Chega a dar RAIVA! Você está ali com seu cartão de crédito, você está ali com seu dinheiro e um funcionário, meu, que é instruído pra trabalhar, pra tratar os clientes bem... ai chega uma travesti, feminina, e ser tratada por 'ele'... Na minha opinião, é falta de educação, é indelicado! Você está sendo indelicado com a travesti. Se ela quisesse ser tratada como 'ele', ela estaria como um rapazinho, ela não estaria ali de menina. Se ela está de menina, é porque ela é menina.

Esta fala de Joyce toma-me por completo, por apontar que todas as burocracias do cotidiano, em nossa cultura, são demarcadas pela comprovação de quem sou a partir do testemunho impresso em papel, muito mais do que sou a partir de quem sou, minha história, meu direito de existir como humano que sou. Ser tratada como "ele", para a narradora, é sinônimo de desrespeito ou indelicadeza, mas também compreendo que este tipo de desrespeito estrutura toda uma lógica de senso de justiça baseada na veritas constituída pelo timbre do nascimento.

O senso de justiça, delimitado neste exemplo do cotidiano de muitas travestis, passa pela normatização de corpos que são subjazidos aos moldes de uma ditadura que prioriza a "verdade dos fatos", comprovados mediante documento de identificação. A comprovação dá-se em busca de uma veracização que, por si só, é quem delega o direito de ir e vir - ou, no caso das travestis, de recuar.

Joyce, em sua narrativa, firma o desrespeito e o descuidado demarcados pela indelicadeza do profissional que atende, mas adiante traz:

porque a pessoa não só tratou como "ELE”, te tirou mesmo do sério! Então, quer dizer... é onde gera violência, onde gera confusão... é complicado!

Ao que parece, a partir de sua narrativa, a confusão gerada em torno do desrespeito e descaso pelo tratamento de pronome "tira do sério" a quem foi desrespeitado, podendo gerar violência. A meu ver, a violência já está dada, imbuída no ato "indelicado" de destrato pelo nome social quando the é solicitado, pois ela 
não é uma punição justa que sofremos, tampouco uma vingança justa pelo que sofremos. Ela delineia uma vulnerabilidade física da qual não podemos escapar, que não podemos finalmente resolver em nome do sujeito, mas que pode ajudar a compreender que nenhum de nós está delimitado por completo, separado de todo, mas sim que estamos todos em nossa própria pele, entregues nas mãos dos outros, à mercê dos outros. Essa é uma situação que não escolhemos. (Butler, 2017, p. 131).

A partir da fala de Joyce e da citação acima, questiono se as possibilidades do direito de escolha e do juízo de valor, delimitado pela historicização do outro sobre nós, não se refere aos modos como as pessoas vão se construindo, tornando-se partes inerentes ao timbre da opinião pública, ao espaço de publicização de sua existência. Tal fato - o da necessidade da autenticação do outro para legitimidade de existir -, por si só, é violento, pois não sustenta a resistência da existência e nem o impasse do nomadismo de gênero, de corpo e de sexualidade.

O paradoxo da violência - paradoxo porque ao mesmo tempo em que ela é imbuída num discurso controlado por uma ordem do imaginário (um tanto perverso) social, é também publicizada sorrateiramente - deixando-se "à mercê" do julgamento do outro. Ser tratada por "ele", quando deveria ser "ela", solavanca uma identidade e a põe em questão. Nessa direção, a alternativa é tratar pelo que se entende como veritas, resguardando-se por um órgão anátomosexual. Eis o julgamento de Procusto ${ }^{47}$.

Assim como falado por Fernanda, anteriormente, existem diversas dificuldades relacionadas às identidades trans que escapam somente da ordem burocrática (como retificação de nome civil, por exemplo) e são refletidas no cotidiano, especialmente no futuro profissional. Reconhecer-se com a identidade travesti, em especial, é demarcada por Joyce como empecilho para a inserção no mercado de trabalho, revelado na fala

Ninguém vê por ai uma travesti do outro lado fazendo um cachorro-quente ou um hambúrguer pra você. Você vê? Não vê! Muito raro! Fala aí pra mim! Não vê!

Este trecho de sua narrativa causa-me um sentimento de tristeza, por ver que (dadas todas as questões já apresentadas e o movimento político brasileiro atual), aparentemente, os empregos que "sobram" para estas pessoas são, geralmente, "periféricos" e que não exigem competências ou recursos necessários.

\footnotetext{
${ }^{47} \mathrm{Na}$ mitologia grega, Procusto era um homem que tinha uma cama exatamente do seu tamanho, à qual era cedida a todos os viajantes que convidava para hospedarem-se em sua casa. Se o hóspede fosse maior que sua cama, eralhe amputado o que "sobrava" do berço, enquanto o que fosse menor seria esticado a fim de que ocupasse todo o comprimento da cama. Nunca ninguém se ajustava exatamente ao tamanho da cama, pois Procusto possuía, secretamente, duas de tamanhos diferentes.
} 
Assim como em sua experiência, na minha prática com o Centro de Cidadania LGBTI e com o Transcidadania, ouvi diversas vezes sobre estas dificuldades, inclusive relacionadas ao "primeiro emprego". Várias pessoas atendidas falavam que, mesmo que se tenha o nome civil retificado e que já se reconheça há muito com uma identidade trans, é problemático voltar-se para duas profissões em específico: ser cabelereira ou trabalhar com prostituição. É problemática esta situação não só pelas dificuldades relacionadas à falta de políticas públicas específicas ou à expulsão destas pessoas da escola, mas por a cultura do mercado de trabalho não possibilitar o direito de escolha dessa população.

Hoje em dia está mais fácil.... Hoje conheço meninas que dizem 'Ai, quero terminar o segundo grau. Quero fazer faculdade!'. Na minha época, não era isso, não! Na minha época, era 'Ai, quero ir pra Europa! Quero ganhar dinheiro, ficar rica! Quero me prostituir!'. Ninguém falava que queria terminar o segundo grau ou fazer uma faculdade.

A ideia de ganhar dinheiro a partir da prostituição aparece como, "culturalmente", fazendo parte do imaginário de travestis e mulheres transexuais, ainda que esta realidade venha se transformando em decorrência de alguns projetos na área de Assistência Social ou Direitos Humanos $^{48}$.

Para Louro (2015), "Na escola, pela afirmação ou pelo silenciamento, nos espaços reconhecidos e públicos ou nos cantos escondidos e privados, é exercida uma pedagogia da sexualidade, legitimando determinadas identidades e práticas sexuais, reprimindo e marginalizando outras.” (p. 30). Todos estes espaços, sejam eles institucionais ou não, exercem sobre esses corpos uma postura de governança, desvalidando as categorias "gênero" e "sexualidade" e estruturando um sujeito que é produto de sua genitália, como também assinala Butler (2015). Assim, o limite social faz-se necessário em meio ao julgamento de corpos centrados na normatividade, pois qualquer outra configuração de corpo não seria legítima e, portanto, indigna de "ter" ou "possuir" um gênero de verdade.

Indo adiante pela narrativa suscitada do encontro com Joyce, encontro certa representação sobre o "feminino", que me chama atenção pelo modo que foi colocado por ela. O trecho em questão fala:

eu descobri que a gente, menina, a gente tem uma prioridade a mais que os meninos, até por a gente ser feminina. É menina, né!? Você passa fome se você quiser. Você dorme na rua se você quiser. Porque você é mulher! É só você saber se articular, saber viver. Sempre fui esperta. Sempre soube usar meu corpo.... descobri que eu tinha um potinho de ouro comigo, então, sempre usei isso a favor da minha sobrevivência. Até hoje, aos meus quarenta e cinco anos de idade!

\footnotetext{
${ }^{48}$ Em especial, na cidade de São Paulo, o Transcidadania.
} 
Acompanhando sua narrativa, entendo que a questão colocada por ela tem a ver com o fato de a prostituição representar, para a narradora, uma possibilidade de o corpo ser "estruturado" via sobrevivência financeira. No entanto, sua fala, de certo modo, indica um possível discurso arraigado da concepção da mulher como um objeto sexual destemido, criativo, potente e resistente. Tais apontamentos entram em consonância com um pensamento patriarcal machista, que compreende a mulher como este objeto de prazer, que detém o "pote de ouro" resguardado para o "bem dos homens".

Por outro lado, se olharmos por uma ótica que desestrutura o objeto sexual e centraliza a mulher como não somente a fonte do prazer, mas a protagonista de um prazer que também é seu, a fala de Joyce aponta-nos que o seu corpo pode ser usado com este intuito de sobrevivência - e por isso falo "potente e resistente" - porém, a partir da sua pretensão, do seu poder de escolha, do seu consentimento.

Obviamente, a fala em questão não abrangeria somente estas compreensões aqui disseminadas, especialmente porque o lugar de fala que tenho é enquanto homem. Caminhando com sua narrativa, percebo que

esbarramos num curioso limite: a insistência dominante na estabilidade dos corpos, no corpo como um fato e na transmissão de informações óbvias. Essa insistência tem mais a ver com a fantasia que supõe que os corpos dizem o que eles querem dizer e querem dizer o que eles dizem. (Britzman, 2015, p. 87).

Esta sinalização parece-me fazer sentido pelo endereçamento que se dá às funções do corpo feminino e do corpo masculino como sendo de "naturezas" diferentes, modos de pretensão calcados no discurso da determinação reprodutiva que circunscreveu boa parte do pensamento ocidental. Assim como na fala de Joyce, não é incomum escutarmos de travestis e mulheres transexuais, especificamente, que o desejo de formar um lar, casar, adotar filhos e viver para o lar, o marido e os filhos é o objetivo central de sua conjuntura em ser reconhecida social e vividamente como mulher.

Nesta direção, é notório que este discurso oriundo, majoritariamente, de uma parcela específica da população, tenha a destreza de incorporar em suas trajetórias este modelo patriarcal de mulher como sendo o ideal, mesmo que seja o falido em nossa sociedade. Este discurso só toma força porque, ao que parece, as minorias espelham-se no que seria a norma.

Evidentemente, não falo de minorias tendo como base os modelos leigos do cenário político brasileiro, nem dos exemplos de meritocracia adotados pela nobreza (entre aspas) da 
classe média, nem, muito menos, das falas imbuídas de preconceito e rechaço por parte de líderes religiosos e seus seguidores. Entendo minoria a partir do que Deleuze e Guattari (2011) discorrem, como não sendo o oposto de maioria, em número, mas como resultado de uma "constante" expressiva relacionada ao padrão proeminente de dominação e poder.

A constante esperada para esse ideal de mulher aparece na fala de Joyce, ao dizer que:

É caro ser mulher!... Porque você não nasce bela! Você não nasce bonita! Muitas mulheres belas, aí, elas têm que ir ao salão escovar os cabelos, têm que estar no salão arrumando sobrancelha!

Tal modelo de mulher é deflagrado pelos ideais de beleza que veiculam nos meios midiáticos. Esta constante é, ao mesmo tempo, inconstante. Inconstante porque tais ideais alteram-se em decorrência das representações de beleza e consumo decorrentes da regulação e normatização à época, tendo como principal norteadora a construção de uma beleza feminina que extrapola os limites do corpo (Andrade, 2013, Vigarello, 2006).

Entendo os limites do corpo não como possibilidades orgânicas, apenas, mas como toda uma construção - inclusive acossada à experiência - estética ${ }^{49}$. Relaciona-se a isso à presença de "invasores" no corpo, que, nas transgeneridades, é compreendido como órgãos sexuais, anatomia, presença de pelos, ossos da face, menstruação e seios, por exemplo. A relação que faço aos "invasores" é apresentada por Joyce, ao falar que para ser travesti é mais difícil e caro que ser uma mulher cis, justamente pelo fato de estarem à mercê de um corpo que, geneticamente, empreende-se a partir de hormônios relacionados ao masculino e que se desenvolve nesta direção.

Retomo essa questão de intervenções no corpo como forma de "reparo", empreendidas, obviamente, pelo ideal de beleza da mulher cis que a mídia apresenta como sendo o modelo e que também foi trazida na entrevista de Fernanda. Neste sentido, penso se não seria necessário refletir este ideal de beleza que a mídia apresenta como sendo um catalisador da experiência de "ser mulher" ou "ser travesti" e, inclusive, se o mercado de consumo não estaria atentando à mercantilização dos corpos trans como incentivo para este "reparo". Retomo aqui o que Joyce sinaliza e que já foi anteriormente apontado, ao dizer que as farmácias aplicam os hormônios em travestis e mulheres transexuais em seus próprios estabelecimentos por entenderem que teriam "uma cliente fixa", que precisaria sempre de seus serviços.

\footnotetext{
${ }^{49}$ Experiência que, ao olhar de Santos (2016), está entremeada ao existir humano como uma criação, pondo em possibilidade uma flexibilidade do modo de viver humano permeado pelas incertezas.
} 
A mercantilização destes corpos, decerto, é um problema de saúde pública não só porque deixa de amparar usuárias e usuários na integralidade de suas ações e em desenvolver estratégias fundamentadas em políticas públicas específicas, mas por deixar de notar que, de certo modo, terceiriza ações que reverberam na violência e exclusão desta população - uma espécie de higienização institucional.

A higiene no modo de questionar as coisas e o mundo não é uma espécie de "tangencial" nas práticas institucionais, como é uma introdução da própria comunidade acadêmica, que não direciona os futuros profissionais sobre as possíveis demandas que podem emanar na prática. Nesta direção, insisto em dizer que a falta de preparo de profissionais de saúde no contexto vivido de travestis, mulheres transexuais e homens trans é um problema caótico de formação. As instituições - e coloco também a academia no mesmo patamar -, segundo Morato (2018), acabam rechaçando a experiência dos que ali convivem e "Reduzindo espaço a modos de ser, visa atá-los firmemente às malhas por elas tecidas." (p. 169).

A emergência de questionar esta falha parte da necessidade de os currículos acadêmicos levarem em consideração abordagens em saúde e educação que lidem com a experiência vivida pela população atendida, muito mais que responderem a uma ordem burocrática que se atenta a quesitos técnicos específicos. É nesta direção que não vejo como necessária uma disciplina específica que "normatize" a questão de gênero e sexualidade na academia, mas que priorize o ensino em educação e saúde como sendo uma prática por si só interventiva, contemplando-os como parte do existir humano.

As águas que surgiram do encontro com Joyce mostraram que é preciso olhar para o avesso e libertarem-se das amarras em torno do sexo e da sexualidade, ao mesmo tempo em que possibilitou pensar o gênero como sendo essa mesma água: fluída, corrente, inconstante. Mesmo interrogando os lugares que a saúde pode adentrar por entre essas questões, pergunto o que nós, psicólogos e psicólogas, poderíamos co-construir enquanto atitude junto a estas pessoas. Acredito que a primeira articulação de uma possível resposta seria atentar-se às águas do rio: seguir a direção pela qual ele toma rumo, acompanhando seu nascedouro contínuo.

\section{3 "Essa palavra presa na garganta": o orvalho de Eduardo no jardim de inverno}

Marquei com Eduardo num espaço de uma ONG. Desde o meu contato, mostrou-se solícito e curioso sobre nossa conversa. Pedi sua autorização para gravar e ele respondeu-me com um sorriso “Claro!”. Ali estava Eduardo na minha frente e, ali, também estava eu. O caminho que nossa entrevista tomou foi desafiador, pois, na maior parte do tempo, vi-me 
martelado pelo seu chamamento. As suas palavras representam, para mim, uma denúncia sobre nosso fazer, sobre nosso saber e, por isso, acredito que transitar neste diálogo, nesta entrevista, faz-me pensar o avesso do avesso, avesso. Sinto-me avessado. Se eu tivesse uma palavra que compreendesse o encontro com Eduardo, ela seria inabitável.

Estranho começar por aqui, por este caminho. Primeiro porque, mesmo que eu tenha sentido esta palavra como fazendo parte de nosso encontro, mesmo com seu sentido claro e possível de concretude, é uma palavra que não abarca notória compreensão minha em torno da história de vida dele. Em segundo lugar, me é estranho começar com a palavra “inabitável” pelo fato de que, mesmo que soasse pelas palavras de Eduardo um desencontro consigo, com seu corpo e com sua experiência, ao mesmo tempo compreendia que sua existência habitava espaços outros que diziam de uma dimensão ética, política e estética - às quais, portanto, tratase de, talvez, uma existência fronteiriça-nômade circunscrita por um corpo que nem mesmo lhe compete e nem compete ao que lhe foi imposto - e que sinalizavam a autoria do seu modo próprio de ser; um modo muito próprio de ser homem que abalaria, politicamente, com o que estaria instituído por "o homem" (Arendt, 2018a). Em terceiro, sinto que nenhuma palavra poderia abarcar e, portanto, habitar o modo próprio de ser Eduardo: um homem trans, um homem trans viado, como ele mesmo fala.

Eduardo fez-me um convite a repensar a minha prática - ou melhor, a psicologia.

Pesquisador - Eu gostaria que você falasse um pouco sobre sua experiência de ser um homem trans.

Eduardo - Então... ser um homem trans é um... (pausa) uma constante luta, eu diria. Hoje, pouco antes de chegar, inclusive, eu estava chorando porque eu estava com dificuldade de sair de casa, por conta de não querer sair com um corpo com o qual não me identifico, sabe? Porque a sociedade me olha diferente. Esse "sair de casa" ser difícil é porque qualquer outra pessoa apenas sai pra fazer qualquer coisa, eu saio já esperando as análises. Eles vão te olhar, sempre, querendo te analisar pra descobrir o quê que você é, sendo que é bem mais fácil perguntar o nome da pessoa. Dependendo do nome, "pronto, homem!", “pronto, mulher!”. Eles ficam... Eu uso binder, que é pra comprimir os seios, que a gente chama de "intrusos". Esses dias, eu comprei um novo que acho que ele não vem sendo tão eficaz como o primeiro. Como ele vai desgastando, o meu primeiro está rasgando e me incomoda muito usar este agora, porque parece que fica, ainda, um pouco do volume na camisa... (pausa) E pronto! Eu sou uma exposição, sabe? Não sei se você 
já ouviu falar dos zoológicos humanos. Os zoológicos humanos aconteciam até meados do século vinte, com as pessoas negras, no caso, quando vivenciavam a escravidão... Eu faço História, então... e aí, eu me sinto muito uma exposição humana! Eles olham, eles ficam surpresos, olham pra calça! Quando não conseguem ver no seu rosto, na camisa, olham na calça, porque homem é pênis! Esse é o reduto de um homem! A gente tem também a prótese, que se chama packer, só que é MUITO desconfortável pra minha pessoa. Cada caso é um caso. Então eu não uso. Eu tenho, mas... não sei... eu me sinto mais confortável usando ele só na hora do sexo. Acho que porque eu cresci sem nada ali, ele mexendo, me sinto confortável sem. Só que ele me faz falta na parte de quando a pessoa vai me analisar e fica olhando tudo e fica... pra baixo (olha para baixo) tipo... (balança a cabeça e gesticula com as mãos). Não é necessário! Não é necessário nem a pessoa querendo me analisar pra saber se eu sou homem ou mulher! Se eu já estou tendo uma postura mais masculina, PRONTO! Essa é a resposta! Fim! (pausa). A gente vai fazer um grupo aqui no Centro de Cidadania, discutindo masculinidades, justamente por isso. O que é ser masculino? Até porque eu sou um homem trans BEM viado! As pessoas ficam naquela coisa e eu sou aquele homem que gosta de vestir aquelas roupas que as pessoas julgam ser bem gay, que são mais delicadas... e aí, para ir pra faculdade, por exemplo, tenho que colocar uma camisa polo, uma calça, porque isso que é masculino, entendeu? Quanto mais rude, pra sociedade, mais homem. E eu não sou assim. Eu não me identifico como mulher, mas sou um homem delicado, digamos assim. Mas eu não posso! Porque aí que as pessoas vão falar "Mulher!" e eu não quero ser visto como mulher! Sinto isso um pouco na faculdade... sentia mais antes! Só que acho que minha mãe me ensinou TANTO a me impor, me aceitar e me respeitar, porque é assim que a gente consegue respeito, que acho que eu fui conquistando isso na faculdade. Eu não tenho medo de corrigir uma pessoa quando ela me trata da forma incorreta, me tratando no feminino... Eu não tive medo de correr atrás do meu nome social no documento da faculdade e fiquei no pé da reitoria durante sete meses, sendo que eles tinham que levar de quinze a trinta dias úteis pra colocar o nome. Todos documentos já têm meu nome, inclusive a carteirinha da faculdade, aí está tudo assim (tira a carteira da bolsa, abre a carteira, retira o documento e entrega-me)... E aí, eu percebo que da faculdade, o que tenho desses olhares de análise, vêm dos alunos... de professor, não, nem de nenhum funcionário... e são daqueles alunos fanático-religiosos! Evangélicos, no caso! Não tem UM que não seja evangélico, que me trate de uma forma... que não seja julgando! São todos evangélicos. Eles todos estão ali num curso de HISTÓRIA querendo provar que 
Deus existe, não estão ali para aprender realmente o que está sendo passado... são um saco, esses alunos! Mas são poucos, três... cinco... de uma classe de cento e cinquenta... Então, é uma minoria. Na universidade onde estudo, não percebo nada do pessoal que trabalha. Inclusive, eles me ajudam, pelo menos no curso de História, porque eu sei de outros alunos trans da UNISA, um até foi palestrante quando a gente fez um evento sobre... identidade de gênero e sexualidade, só que ele é de medicina, então não sei muito, porque são cursos muito distintos. No curso de História, a partir do momento em que um aluno diz "Olá, professor! Sou um aluno trans, esse é meu nome, quero ser tratado dessa forma, é assim...”, pronto! Ouvi umas duas vezes de meu reitor errar, mas eu consertei na hora e foram só essas duas vezes, até porque a gente estuda muito essa questão da identidade de gênero, sexualidade e sexo também, para a infelicidade dos evangélicos, porque eles odeiam quando a gente tem aula disso (pausa). Inclusive, eu estou lendo um livro da Sara Salih, que se chama "Judith Butler e a Teoria Queer", e essa aula temos que estudar isso, justamente porque como nós vamos ser professores, temos que entender que na sala de aula vai ter todo tipo de aluno. O aluno passa mais tempo na sala de aula do que na própria casa, entendeu? Então nós participamos bastante da criação desses alunos! Aí, um aluno meu vai chegar, suponhamos que eu seja um homem cis, e aí uma aluna minha vai chegar "Ah, eu sou uma aluna trans!", o professor vai ter que saber lidar com isso, entendeu? Por isso que a gente estuda isso bastante e eles [os professores] estão bem a par, estudam bastante sobre isso. Eu diria que isso [as questões de gênero e transexualidade] vêm vindo... vêm sendo tratadas na universidade há menos de cinco anos, com toda certeza do mundo! Por isso que ainda há uma resistência dos alunos! Eles não esperavam abordar sobre a psicanálise de Freud, que fala que a gente não nasce nem homem e nem mulher, que a gente se constrói. E eles [os alunos evangélicos] dizem “Como assim?”, às vezes, muito indignados! Alguns falam “Tá, se aborda tudo... mas o que isso tem a ver com História?” e os professores "TUDO a ver com HISTÓRIA!!!”. Isso aqui é História! É bem bacana! Mas, na faculdade, nunca tive problema. não. Na escola, tive uma vivência feminina. Ainda que eu me sentisse menino, que tivesse certeza disso, eu não conseguia ver oportunidades de mostrar, porque a escola em que eu estudei era muito LGBTIfóbica... É LGBTIFÓBICA!!! tinham profissionais que eram contratados para me vigiar, porque eu tinha uma namorada na escola. Foi terrível! Eu sempre fui bastante resistente a qualquer tipo de injustiça, acho que sou bastante limitante, até. Eu bati de frente com a diretoria. Não me calava. Jamais me calo em nenhuma circunstância. Nem nesse caso (pausa). Assim que me formei, os alunos LGBTIs não 
tinham mais espaços nessa escola. É uma escola particular. Eles foram saindo, porque não aguentavam, já que eu era líder, sabe? (pausa) E também os funcionários LGBTIs foram demitidos... POR SEREM LGBTIS, por nenhuma outra razão! Então, eu percebia isso. Se eu já tinha toda uma luta por me relacionar com alguém do mesmo sexo - e, por sexo, eu digo genital - que eu não via nenhuma brecha em que eu pudesse dizer "Sou um homem trans.". Aí, foi o que mudou toda minha vida lá. Eu era uma mulher lésbica, mas não me reconhecia como uma. Só quem sabia da minha identidade de gênero era minha namorada da época e depois minha namorada atual. Minha família... é um pouco difícil. Hoje em dia, é um tranquilo. A família inteira "Eduardo"... "meu sobrinho", "meu neto", "meu irmão", mas antes, até que eu conseguiria ter uma vida masculina na escola, caso eu tivesse visto essa abertura pra me relacionar com minha família antes, porque como eu não tinha apoio da família, não tinha como. Daí, acontece que minha mãe era muito transfóbica, porque ela chegou a conversar comigo umas quatro vezes, em quatro épocas diferentes da minha vida, falando que se eu quisesse ser homem, ela deixaria de ser minha mãe, me expulsaria de casa... Ela chegou a dizer que preferiria me ver morto que mudando todo meu corpo. Isso foram coisas que, quando eu ouvi... a primeira vez eu tinha sete... a segunda vez eu tinha doze... a terceira, catorze... a quarta vez, antes de me assumir, eu tinha dezesseis. Isso foi bloqueando tudo em mim! Foi me assustando, foi me dando medo de querer viver. Eu digo que eu ainda batalho por minha vida! Eu tenho que fazer uns exames pra começar com a testosterona, e aí, eu fui marcar, que minha mãe pra marcar médico é terrível! E ela é psicó... psiquiatra! Trabalha nessa área e é meio doida! Aí eu peguei meu cartão do convênio e marquei dia vinte e dois. Minha mãe chegou ontem e falou que não vou no dia vinte e dois, que vou dia vinte e nove. Porque se eu for no dia vinte e nove, eu vou conseguir ir no Einstein [hospital] e, no Einstein, ela não paga. Não entendi nada! Só que me parece que está sempre adiando, sabe? Eu já tenho um ano e meio... um ano e sete meses em terapia e, segundo a Violeta... é que eu fazia em outro lugar, fazia no particular... segundo a Violeta, era só pra eu fazer em seis meses e já tem um ano! Um ano! É muita coisa! Está sempre adiando. Me parece que minha vida está sempre sendo adiada. Entende? Enquanto eu não começar essa transição física, porque a social, eu já estou... já faço... já comecei há muito tempo (pausa). Me parece que estou parado, sabe? Eu não consigo emprego porque eu vou lá levar currículo e o cara chega lá... olha o meu rosto... e o meu nome... não é! Não chama! "Ah, qualquer coisa a gente te liga." ... Ah, não liga. Justamente porque o nome não bate com minha feição. Ainda não tenho nome retificado, porque minha mãe quer que eu vá com calma (pausa). Mas 
ela quer ser entendida e eu não tenho voz dentro de casa, perante a isso. Então, eu sou muito sozinho. O título... comecei a ler, mas ainda não estou nem na metade... o título do livro do João Nery, "Viagem solitária”, é muito isso. É uma viagem solitária! Não importa quantas vezes minha mãe diz que ela quer participar... ELA NÃO QUER, de fato!!! Porque toda vez que há um passo a mais pra eu dar, ela recua DEZ, entendeu? (pausa longa). É PÉSSIMO!!! É PESSIMO!!! Porque eu vou fazer dezenove anos e ainda não trabalho! (pausa longa). Minha vida está passando... eu dependo dessas pequenas mudanças que não vão afetar NINGUÉM! Não vai afetar ninguém se eu retificar meu nome. Não vai afetar ninguém dar continuidade na terapia hormonal, sabe? Continuidade não... dar início. Não vai!!! Eu ainda não fiz nenhum uso de hormônio. Estou numa fase que tenho que fazer dois exames no clínico geral... a mamografia e a... acho... mamografia completa. Esses dois exames. Tem que marcar a consulta, depois tem que marcar os exames. Demora muito! Pra depois pegar o resultado desses exames, o laudo desse clínico, o laudo da psicóloga, o laudo da psiquiatra...OLHA QUANTOS LAUDOS QUE UMA PESSOA PRECISA PRA VIVER!!! (pausa longa). Pra ir lá no endócrino [médico], com todos os laudos pra mostrar... com OITOCENTAS PESSOAS atrás de mim dizendo “EU ACREDITO QUE ESSA PESSOA É TRANS!!!”. EU sou trans, não é VOCÊ!!! EU JÁ ESTOU DIZENDO QUE SOU TRANS! EU ESTOU DIZENDO QUE QUERO MODIFICAR MEU CORPO, QUE QUERO MODIFICAR MINHA VIVÊNCIA SOCIAL!!! Não é Hortência, não é Liz, não é Violeta ${ }^{50}$, não é... nem sei o nome do clínico, não é endócrino... não são essas pessoas que vão viver a minha VIDA!!! E por mais que eu apoie essa ideia de que o trans precisa sim de um acompanhamento psicológico, eu apoio porque acho que TODO mundo precisa de um acompanhamento psicológico, não é porque sou trans que eu preciso, sabe? Não é porque... que eu preciso de minha psicóloga pra eu ter CERTEZA de quem eu sou. Eu preciso dela porque eu quero chegar nela e dizer assim "Olha, hoje tentaram me matar! O que eu faço?". Entendeu? É pra ISSO que eu preciso de uma psicóloga. Porque ela é minha ÚNICA aliada! Semana passada, eu falei pra ela. E me dói muito, porque eu queria chegar em casa e dizer "Mãe! Aconteceu isso.”. E não posso. Não posso. Preciso encarar uma postura de que ser trans é legal, de que ser trans não machuca, porque aí minha mãe vai apoiar. Se eu mostrar um pouquinho de fraqueza referente a eu ser trans, ela já não vai mais me apoiar. Eu dependo dela, financeiramente. Ser trans é uma resistência (pausa

\footnotetext{
${ }^{50}$ Nomes fictícios, a fim de preservar a identidade das profissionais.
} 
longa). Ser LGBTI! Ser negro e não alisar o cabelo! Deixar o cabelo natural... é uma resistência! Não deveria, mas é. Hoje eu falei pra minha namorada que eu ODEIO ser trans. Foi a primeira vez que eu falei, mas eu odeio (pausa longa). Sério (pausa longa). Não sei em outras realidades, em outras sociedades... (pausa) mas NESTA que eu vivo está cada vez mais difícil (pausa). Principalmente pelo machismo, porque se eu não for MACHÃO... se eu não vestir as roupas que eles querem que eu vista, não sou homem.... os homens cis, as mulheres cis, a sociedade, no geral. Existe machismo na própria população trans. Eu costumo dizer que TODO homem é machista. Seja ele cis, seja ele trans, seja ele hétero, bi, gay, qualquer outra sexualidade... acredito porque... por uma cultura enraizada. Eu sempre luto contra o machismo dentro de mim, porque eu posso ter, às vezes, um comentário ou comportamento machista. Como, por exemplo, quando passa uma moça bonita na rua, eu me pergunto "Por que eu vou olhar?". Entende? Mas, antes, eu não me perguntava. Hoje eu pergunto. Porque eu penso que não é uma exposição de carne! (pausa). Sem contar que também sou contra a indústria de carne, então... (pausa longa). Os homens trans lidam bem com essa questão de ser mais viado, até porque a maioria dos homens trans é pansexual. Não sei se você já ouviu falar... eu me identifico como pansexual, me atraio pra pessoa independentemente do gênero com o qual ela se identifica... Mas eu tenho menos atração por homem cis, porque... Não, mentira! Porque o homem cis gay é muito mais legal que o homem cis hétero. Enfim... A maioria [dos homens trans] é pansexual, então, ainda que tenha os homens trans hétero, eles não têm essa questão de "Você é menos homem que eu porque você é gay.". O que percebo de machista nos homens trans é com as próprias mulheres, o que me deixa muito PUTO, porque eles já tiveram uma vida feminina, querendo ou não. É um absurdo, na minha visão, a gente negar a vida que a gente teve antes! Antes de Eduardo, existiu uma outra pessoa com outro nome, que não tem nada a ver com Eduardo, inclusive. Eu não posso... sempre me senti um homem, mas nem sempre eu FUI um homem, entende? Eu tive toda uma vida feminina, então eu tive... eu fui uma MULHER! Eu sai na rua... EU FUI ESTUPRADA (pausa), enquanto mulher! Isso, sem ser pra você, eu falei pra duas pessoas (pausa). Eu saía na rua e uma vez eu tive que pedir ajuda ao cara que estava vendendo hambúrguer e falei assim "Olha, tem um carro me seguindo. Não para... eu entro numa rua e ele entra na rua.". Era um carro vermelho, parecia tipo um UNO [modelo de carro]. Eu levei minha irmã no karatê e estava voltando. O carro veio me seguindo porque eu estava de short e de camisa e ele achou que estava legal e que tinha o direito de parar o carro e falar pra eu entrar no carro dele e ficar me chamando de delícia! Eu tive essa 
vivência! Tive a vivência de me PREOCUPAR com o que iria vestir (pausa) pra não mexerem comigo. "Eu quero vestir aquilo, mas tenho que vestir essa blusa aqui, porque a gola é fechada (pausa). Está calor, mas vou vestir essa aqui. Aí eles vão mexer menos.”. Não vão parar de mexer, mas vão mexer menos. Eu tive toda essa vivência feminina de que, por mais que eu não goste de maquiagem, eu tenho que usar, porque aí eu sou mulher. Eu não uso maquiagem até hoje! E adoro maquiagem, acho super legal, sou "mó viado"! (sorri). Nem todo viado usa maquiagem, a gente sabe, mas eu acho legal! (pausa). Eu não sabia usar e eu tinha que usar. Agora, como homem, muitos homens trans que conheço são machistas com mulheres, sendo que eles tiveram aquela vivência. Então. isso é uma coisa que não consigo entender! Machista no sentido de que ele assedia mulher na rua (pausa) e reclama de quando era assediado. Então, é uma hipocrisia. Machismo é uma hipocrisia. Todo tipo de coisa que oprime é hipocrisia, de certa forma. Pelo menos, vejo assim... Esse é o único machismo que vejo nos homens trans, por isso, digo que todo homem é um pouco machista. Tudo que se volta pra o feminino, sofre (pausa). Tem muito homem trans que não tem nada de feminino, só mesmo... eu só vejo algo de feminino nos homens trans que gostam de outros homens, nos homens trans gays. Não porque eles são gays, mas só nesses que vejo algo de feminino, nos outros, não. Não sei se é porque eles têm que estar sempre reafirmando pra sociedade que é HOMEM, então são até mesmo mais BRUTOS que homens cis. Não sei... mas eu não me preocupo muito em querer me reafirmar na sociedade! Eu levo minha vida assim: nenhum homem cis hétero chega numa sala e fala assim "Oi, eu sou um homem cis hétero." Eu não vou chegar e falar "Oi, eu sou um homem trans pan.”. Entendeu? Não vou! Mas tem muito homem que faz (pausa). Eu não vejo como importante. Acho até um desrespeito... sabe aquele preconceito entre a gente? Porque se a gente está querendo lutar por um espaço, é só a gente chegar no espaço! Nós temos direito de usar esses espaços, sendo trans ou não! Esse é sempre o nosso discurso: sendo trans ou não! Então, por que toda hora você tem que falar que é trans? É bem mais fácil de falar se a pessoa te perguntar, se a pessoa não te perguntar, não tem problema nenhum! "Sim, eu sou trans." ... mas enquanto a pessoa não me pergunta, ela que se foda na análise dela "Meu Deus, é homem ou mulher?". Vai me incomodar? Vai! Mas não interessa a ela o que sou. Então acho... na minha vivência... tem alguns que toda hora necessitam de falar que são trans. Não sei... pode ser que porque... talvez tenham muitos traços femininos neles ainda. A mulher transexual não fala que é mulher transexual, porque os traços são bem mais brutos do que os nossos. Então ela chega e todos já sabem. Eu duvido que a gente chegue e as pessoas não saibam. Está na minha 
voz!... (pausa longa) O meu problema com os laudos é a demora. Antes, eu fazia pelo plano particular, então fiquei um ano e meio com o particular. Não consegui nem pelo convênio, porque com ele, pra conseguir uma psicóloga ou um psiquiatra é MUITO difícil! É quase mais difícil... NÃO! É mais difícil que o público, porque a minha prima conseguiu pelo público e eu lá procurando pelo convênio e não consegui. Minha mão já tinha me levado pra uma psicóloga quando eu tinha uns doze anos e agora eu voltei pra ela, apesar dela não ser especialista em sexualidade e identidade de gênero, como a psicóloga que eu passava era. Aí, minha mãe trabalha em CAPS $^{51}$ e ela já tinha trabalhado com essa psiquiatra, que é especializada em sexualidade. Então, a gente passou com ela também. Só que eu estava gastando cerca de dois mil e quinhentos reais por mês! E a gente não tem esse dinheiro! Aí eu procurei por um lugar público. Não fazia ideia que existia o Centro de Cidadania LGBTI! Não fazia IDEIA!!! Isso é péssimo! Porque tem muita gente que precisa de ajuda. É aquela coisa... a falta de informação... do próprio sistema. Porque eu também não fazia ideia da PEP... do negócio da Aids... Conheci um cara que, por conta de não saber da PEP, vive com o vírus. É vírus, né? (volta-se para um cartaz sobre HIV que tem afixado na parede). Ele é superlegal, inclusive. Eu não fazia ideia desse lugar aqui! Eu fiquei um ano e meio lá e quando eu cheguei aqui, faz um mês que estou aqui. A Violeta foi quem me atendeu, ela quem me atende. Aí, ela falou "Olha, pra você ir pra terapia hormonal, você precisa de seis meses de terapia com a psicóloga e a psiquiatra, você precisa pra cirurgia.". Então, é uma falta de informação que me gasta tempo!... Eu vou fazer a mastectomia ${ }^{52}$, porque os seios... (pausa longa) eu tenho disforia! Eu tenho muita disforia com a minha voz e com os intrusos. Eu falei com a psiquiatra sobre disforia. Pelo que falei com ela, é quando a gente se sente desconfortável com algo em nós e a gente sente... não é um QUERER, é uma NECESSIDADE da mudança. Eu tenho essa disforia com os intrusos. Agora, tenho um amigo meu que tem uma disforia com o genital. Eu já não tenho!... O "intruso" seria essa massa de gordura (aponta para a região do peitoral) que... simplesmente cresce no corpo... que não é dele. Esse corpo não é dessa massa, esse corpo é MEU! Acho que é por isso que os homens chamam de intrusos, porque eles são intrusos no nosso corpo. Diferente dos seios da mulher. Elas fazem parte daquilo e aquilo faz parte delas. É por isso que a gente [homem] chama de intruso... mas é só uma questão de filosofia mesmo (pausa). Eu descobri, recentemente,

\footnotetext{
${ }^{51}$ Centro de Atenção Psicossocial.

52 Atualmente, esse tipo de cirurgia é reconhecido como mastoplastia masculinizadora, por ser tanto um procedimento de retirada de "seios", como de masculinização de tronco para homens trans.
} 
que já faz algum tempo que eu não tinha relações sexuais com minha namorada atual, porque ela era virgem... eu descobri, recentemente, que eu tenho um problema quando chega pra me tocar. Tanto que, como falei, o packer, eu uso pra relação sexual. Mas eu me sinto muito seguro com ela, então eu deixo as coisas rolarem. Ela já me tocou umas duas vezes... é... foram umas duas vezes. E aí... ainda com um pouco de receio, mas não vi problema. Agora, pra relação sexual, eu prefiro ser o ativo (pausa) com mulheres, pelo menos. Não sei se é porque com homem é... ele já tem ali (aponta para a região genital)... o homem cis, pelo menos. Eu nunca tive relação sexual com homem cis, mas já fiquei com homem cis e trans. Eu tenho... assim... tanto faz a posição de ativo ou passivo, só que... eu acho que prefiro mais ser ativo na relação sexual. Eu não vejo problema com minha genital porque... foi muito engraçado, porque o packer que eu tenho serve pra cinco funções: o prazer próprio, para o sexo... o prazer do outro..., volume, urinar e masturbador, porque se eu bater uma punheta, eu sinto. Pra urinar, (sorrindo) é a pior merda da vida! A pior coisa! Você mira ali e o negócio faz assim (demonstra com a mão como se o packer não alcançasse a mira) não dá, não vai! É muito difícil, muito difícil! Aí a gente... tem uns negócios que os caras falam "Meu, eu estava treinando no chuveiro, não acertei UM!!!’! Que loucura! Não vai! E pra mim é MUITO anti-higiênico! Porque eu estou acostumado a ir ali, bonitinho, sentar, pegar papel... eu gosto disso aqui, dessa minha questão, e também porque ano passado eu tive sintomas obsessivos compulsivos. Não chegou a ser um TOC, estava mais para um SOC, como a minha psiquiatra chamava. Até hoje eu tenho umas coisinhas... tudo que tem que virar de um lado pra outro, é muito imbecil, porque... eu dou maior volta pelo lado direito. Na minha biblioteca, com meus amigos, eu dou maior volta pra subir pela escada do lado direito. É muito doido! Pra mim, tem que ser do lado direito... não sei. Eu andava na rua fazendo assim com a mão (fricciona um dedo no outro) e contava todo quadradinho que via. Maior doideira! Hoje eu já não faço isso, mas se eu estou nervoso, faço tipo uns rituais, sabe? Daí, eu fiquei com essas manias de limpeza, então o packer não vai!... pra urinar, no caso... porque você não precisa se limpar! É como se você tivesse um PÊNIS! É UM PÊNIS!!! E eles são tão reais! Só que eu me sinto sujo, porque eu estou acostumado a TER QUE limpar com papel higiênico, então por isso que não tenho problema com a genital. Quando eu uso [o packer]. é muito estranho, porque tem um negócio ali entre minhas pernas! Pra você fazer sexo, você precisa da cinta, que aí ele fica preso, mas pra o dia a dia você não precisa, só encaixa ali. Tem umas hastes assim (mostra com os dedos) que você encaixa no clitóris e aí você deixa na cueca e fica tranquilo. Só que é uma doideira, porque tem duas bolas ali 
e um negócio ali e você vai andando... eu uso muita roupa de academia... nem fazia academia, mas já usava... e aí todo mundo olha! Parece que o negócio está vivo! Eu fíco tipo “Meu Deus!", dá maior vergonha, sabe? Eu gosto de usar ele assim, no dia a dia, mas por exemplo, quando eu ia no banheiro, tirava tudo! Demorava mais que o necessário no banheiro por conta disso! Aí não tenho problema! De vez em quando, até uso. Mas é aquela coisa... eu não me sinto desconfortável com minha genitália, diferente da maioria dos homens trans... A minha psiquiatra, que eu passava, até que me via... a minha transexualidade como não-binária. Às vezes, pode até ser, não sei. Porque eu me identifico como homem, não me identifico entre um e outro. Então eu não digo que sou não-binário, mas... (pausa) Eu achava um pouco... eu nem sei o que achava, porque ela dizia que eu era não-binário! Só que eu não me identifico como mulher NEM UM POUCO! Talvez só pelo fato de eu não ter problema com minha genitália, mas ainda assim, me sinto como um homem de boceta, como as mulheres falam que são mulheres com pau... no teatro. Eu não me identifico nem um pouco como não-binário. Fico só nessa... "Ah, eu sei que não me identifico como não-binário. Mas... está bom, pra ela, eu sou não-binário.” Não fez muita diferença, na minha vida, o que ela acha ou não, então... a única coisa que muda na minha vida é ela achar que eu estou apto pra testosterona, daí muda muita coisa. Muda o fato de que vou conseguir, mas eu saí dela (pausa). Eu gosto bastante do trabalho que a gente faz em terapia, porque eu gosto muito da discussão que eu tive sobre isso com a psicóloga, me ajuda muito. Minha namorada quer ser psicóloga e, quando ela me disse, eu disse “Que lindo!” ... porque é a profissão que eu mais admiro! A única pessoa que eu tenho pra falar tudo é minha psicóloga! É como o diário de Anne Frank para Anne Frank (pausa). É isso que acho. Acho superlegal. Só que eu acho MUITO demorado. Entende? Acho que... acho MUITO DESINFORMADO, porque os profissionais do Centro de Cidadania estão fazendo de um jeito. A cada seis meses de terapia, eles já sabem se você pode ou não. Isso para a psicóloga mandar para o CRT. Daí, começam todos os exames, marca, aí demora pra fazer... e um MONTE de exame! Por que não passa todos exames de uma vez só? Tem essa! Não passam os exames de uma única vez! (pausa). Começa a psiquiatra também... tem que fazer dois anos com a psiquiatra. O cara já está em testosterona, ele vive uma vida que já está do jeito que vive... seja um cara, seja uma mulher... e ele tem que fazer DOIS anos com um psiquiatra, pra poder ele fazer a cirurgia! O binder machuca! O binder deixa a pele flácida! Mas ele precisa de dois anos com a psiquiatra pra fazer a cirurgia (pausa). Eu acho isso um absurdo! Esse tempo todo! Comigo, já aconteceu de ter umas feridas, não muito grandes... 
acabei tendo alergia a suor, muitos homens acabam tendo alergia. O meu [binder] é um colete, desse material cirúrgico (mostra uma alça do colete). Ele é um colete, porque faixa machuca MUITO as costelas! Você sente deformando o seu corpo. E ele não cobre tanto, porque tenho seios bem grandes. No meu caso, acho que a faixa não funcionou, então, não uso... só colete. Ele é bem quente. No calor, sua muito, e, de coçar, abre umas feridinhas... A pele fica flácida! Fica bem flácida! Na cirurgia, isso complica! Então, quanto mais deforma a sua pele, mais complicação essa cirurgia vai ter, mais difícil vai ser pra ele... E essa é a questão que me bate! Porque pra você fazer cirurgia, através dos psiquiatras... O cirurgião que eu fui conversar disse "Não, você não precisa estar em testosterona, você só precisa de tal laudo.". Só que outro cirurgião já falou "Não, você precisa de tal laudo e tal laudo!", entendeu? Então, precisaria de UMA ÚNICA coisa. Porque com a outra médica que eu estava passando, eu precisaria da psiquiatra pra tomar testosterona. Aqui [referindo-se ao acompanhamento no Centro de Cidadania LGBTI], eu não preciso! Na clínica... no Hospital das Clínicas, você precisa de dois anos com a psicóloga E com psiquiatra para tomar testosterona! A gente precisa DE UM SÓ, entendeu? Todo mundo tem que trabalhar de UMA ÚNICA FÓRMULA, digamos assim. Com uma única direção! Porque todos estão buscando o mesmo resultado! A questão da cirurgia (pausa) nesse que estou fazendo... eu vou começar a hormonioterapia antes de fazer os dois anos na psiquiatra. Eu já estou vivendo há um ano e meio como Eduardo! Eu assino como Eduardo! Meu nome mudou para Eduardo. Minha família me chama de Eduardo. EU DIGO QUE SOU HOMEM!!! EU QUERO TIRAR ISSO AQUI [bate no peitoral] DO MEU CORPO!!! Por que eu preciso de DOIS ANOS com a psiquiatra? Pra ela falar "Então está bem! Você pode!"? Nestes DOIS ANOS, TODOS OS DIAS estou usando um negócio que está deformando meus seios! E eu não vou deixar de usar! Porque se eu deixar de usar, não saio de casa! Entende? (pausa). Eu não acho os laudos desnecessários. Eu conheço muito homem trans que faz [hormonização] por conta própria. MUITOS!!! Eu conheço POUCOS que fazem acompanhamento! Conto nos dedos. Os hormônios vão mudar não só o físico, mas o psicológico. Isso pode, às vezes, causar um "piff". Você vai ficar meio enraivecido, nos primeiros meses. A libido vai crescer muito, muitas coisas vão mudar! Então a gente precisa desse profissional pra chegar e dizer o que está acontecendo com a gente. O psicólogo acalma. O psicólogo... Quem está de fora enxerga melhor. O que eu acho desnecessário é TODO O TEMPO que a gente passa pra conseguir as coisas! E também a questão de que cada lugar faz de um jeito. Por exemplo, agora o STF declarou, dia um do três, DIA UM DO TRÊS... fazem 
dois meses que eles declararam que a gente pode ir no cartório e retificar. Aquele cartório faz, aquele cartório não sabe... gente!!! O sistema tem esse defeito! Por que todo mundo que faz o mesmo trabalho não faz de uma única forma? Seja no particular, seja no Centro de Cidadania, seja no Hospital das Clínicas, pelo SUS... vamos fazer de um jeito só! Que não seja tipo... só uma pesquisa. Porque é isso que eu vejo. Eu não me importo de ser objeto de pesquisa pra ninguém, porque eu sou de História, então eu sei que somos objeto para pesquisar. Só que, nesses dois anos com a psiquiatra, no Hospital das Clínicas, é TOTALMENTE uma pesquisa feita! TUDO que eles fazem ali é uma pesquisa! Tanto que eles não atendem maior de idade agora, só de menor, porque de maiores de idade, eles já sabem a vivência. Eles, agora, querem saber qual a vivência trans de um menor de idade. ENTÃO, É UMA PESQUISA!!! Todos aqueles corpos são objetos de pesquisa! Aí, ficam dois anos deformando os seios dele porque A PESQUISA NÃO ESTÁ PRONTA! Isso é HORRÍVEL!!! Horrível! Eles já sabem que aquela pessoa não vai deixar de usar aquela coisa que está deformando, porque aquilo dali vai mostrar o que ele não quer mostrar (pausa), Eu acho que tudo que é diferente do padrão, é aquela coisa “Nossa! Vamos descobrir?”. O ser humano, desde sempre, tem essa questão de descobrir, de saber o que é aquilo. Por enquanto, o trans, ele está nisso. É mais um objeto de pesquisa do governo, mais por uma curiosidade, porque tudo que descobre de como é trans, eles publicam. E, pra gente, é uma publicação ridícula! Porque, tipo assim: homem trans também pode gostar de homem. Aí eles ficam “MEU DEEEEEEUS!!!”! Minha avó fica horrorizada! Fica assim “Não acredito! Então porque não ficou uma mulher?”. Gente!!! Eu acho que eles lançam por curiosidade, mas acho que até ajuda, de certa forma, porque informa. Tudo que informa é bom. Só tem que melhorar essa questão do tempo. Porque agora, assim, eu vou ter que fazer mais um ano e meio com a psiquiatra e eu nem fui pra ela ainda... pra fazer a cirurgia... mais um ano e meio! Eu já vou estar em testosterona. Como disse antes, já estou vivendo como um homem. Por que tenho que ficar todo esse tempo? Porque ela precisa ter certeza! É isso que acho errado. Eu acho que os profissionais têm que estar aqui pra ajudar a gente na questão do viver! (pausa). Ajudar como se estivesse ajudando uma pessoa cis... porque... a minha psiquiatra tem que ajudar na questão referente à minha ansiedade, depressão... porque eu tentei suicídio! Eu preciso de minha psiquiatra pra isso, porque eu penso em suicídio TO-DOS OS DIAS!!! Eu não quero saber do que minha psiquiatra acha... de se está certo ou não tirar meus seios. Eu que estou dizendo que está certo! É MEU CORPO!!! EU QUE TENHO QUE DIZER ISSO!!! "Você precisa estar aqui comigo, psiquiatra, pra me ajudar a entender porque eu 
penso em me suicidar.”. Tem tudo a ver com minha transexualidade. Tudo a ver. Tem a ver com a questão de que eu quero tirar e eles não me deixam tirar (pausa longa). Tem tudo a ver (se emociona um pouco). A minha ansiedade tem tudo a ver (pausa). Tem a ver com as questões sociais, esse sentimento... depressivo. Porque... o que causa toda essa tristeza... eu não diria tristeza... eu me sinto sufocado! Então... todo esse sentimento de estar preso... é o social. A ansiedade... é a questão... de que está adiando a minha vida! Porque eu passei a minha vida INTEIRA e eu CANSEI de esperar pra viver (pausa longa). A psicóloga que eu passava antes, ela nem sabia o que falar, porque ela não sabe NADA disso. Primeiro, ela é SU-PER CA-TÓ-LI-CA!!! SUPER, SUPER, SUPER!!! Dizia ela que deixava a religião fora do trabalho, mas ela não deixava (pausa). A psiquiatra... eu não entendo do porquê toda vez ela falar assim "Em fevereiro, a gente vê essa questão de te passar para o [médico] endócrino.”. Chegou fevereiro... "Em março!"... Chegou em março... “Abril!". Nunca a questionei, mas não sei o porquê dela me passar, a toda hora, pra o próximo mês. Eu não entendo! Com Violeta, eu falo pra ela... ela me atendeu quatro vezes só... eu já falei pra ela que não entendo porque estavam sempre adiando, não entendo porque é sempre isso, sempre adiando. Toda vez! Agora, tenho que fazer esses dois exames com o clínico geral. Fui marcar sozinho, sem precisar de minha mãe, sem nada! Marquei pra dia vinte e dois, pelo convênio (pausa longa). Eu acho que, como toda profissão, o psicólogo vai ser especializado numa área. Quando a gente quer passar num psicólogo, a gente JÁ SABE porque a gente quer passar no psicólogo, então a gente procura alguém que seja especializado no que a gente quer passar... (pausa). Da mesma forma de que se eu quero cuidar dos meus olhos, eu vou no [médico] oftalmo, porque é especialista naquilo ali. Não... nem cobro de TODOS os psicólogos saberem atender esse público, porque um psicólogo que é especializado em sexualidade, não vai poder ajudar tanto um drogado, um alcoólatra, que um especializado em álcool e drogas. Mas, eu digo que... seria legal que todos estivessem cientes que existe. Por exemplo, essa psicóloga que eu passava dizia "Não sou especialista!" (pausa), "Mas se você achar alguém que é especialista, acho melhor.". Talvez a demora no laudo venha disso... Acho que a questão de não ser um especialista pode atrasar. Essa minha psicóloga que eu passava só sabia que eu precisava de uma psiquiatra, mas ela não sabia que com um laudo dela de seis meses, eu já poderia ir num [médico] endócrino... eu também não sabia. Quando eu soube, ela até ficou com um pé atrás, porque eu ataquei. Violeta pediu um laudo dela e o laudo dela está... TERRÍVEL! Tem coisa errada. Violeta falou pra ela "Você não pode mais usar isso, por conta do artigo um de dois mil e quinze.”, um negócio assim... No laudo 
dela, está assim "Eduardo afirma...", "Eduardo DIZ querer...", ela não afirma NADA. UM ANO E MEIO E ELA NÃO AFIRMA NADA!!! Já o laudo da psiquiatra está dizendo que Eduardo... ela é especialista em sexualidade... "O paciente Eduardo tem uma vivência de um homem transgênero...", ela estava afirmando coisa dela. "Percebo que ele está propício a usar o nome em tal instituição...", sabe? Essa coisa do "ele afirma", "Percebo que...”, a psiquiatra estava falando! A psicóloga estava dizendo o que eu disse... com as palavras dela, e usando um termo que está ultrapassado há um tempo! Essa psicóloga parou e não estudou mais nada! Eu acho importante o profissional já colocar o parecer dele, porque é isso que as pessoas querem no laudo... é pra isso que as pessoas pedem laudo! Num laudo no qual a pessoa só diz que EU me afirmo, que EU estou dizendo, ela não está dizendo nada! Porque se eu me arrepender, a culpa não é dela! Por isso que ela não vai se pôr ali. Muitos deles não se colocam. Por isso que acho que é necessário colocar. Se não fosse necessário, não precisaria de laudo, então FODA-SE essa merda desse laudo e me deixa viver minha vida! Mas já que preciso desse laudo, você se coloque aí nesse laudo, porque eu estou UM ANO E MEIO COM VOCÊ!!! EU QUERO saber o que VOCÊ tem pra dizer. Eu preciso da SUA palavra. Se eu precisasse SÓ da minha, iria DIRETO LÁ E AFIRMARIA!!! Mas eu preciso de um PAPEL! De um parecer DAQUELA pessoa. Se no laudo for ter SÓ o que eu digo, e não o parecer da pessoa, eu não quero mais precisar de laudo! É a MESMA coisa de não ter um laudo nenhum! É a mesma coisa de NÃO PRECISAR de um laudo, esse só colocar “Eduardo diz...”! (pausa). Mas eu preciso de um laudo... por enquanto... e o laudo precisa da palavra de um profissional. Este é o ponto errado do laudo de MUITOS profissionais que nos atende. Porque é aquela coisa "Não vou pegar a culpa pra mim!", porque eles têm medo que a gente se arrependa. Se a gente se arrepender, volta! Se eu me arrepender, pago cartório pra mudar meu nome de novo. Se me arrepender, eu paro de tomar meu hormônio (pausa). Só que eu acho MUITO difícil uma pessoa se arrepender! MUITO DIFÍCIL!!! Eu acho mais fácil uma pessoa se arrepender de ter engravidado do que mudar todo seu corpo. Deu TEMPO pra eu entender que sou trans! Por isso, tive o meu tempo pra chegar à minha família e dizer que sou trans (pausa). É tudo uma questão de análise! A gente pega e põe tudo na mesa... (pausa). Porque até você AFIRMAR, você dizer EM VOZ ALTA: "EU VOU TIRAR OS MEUS SEIOS!!!”, já é algo muito bruto. Você já está AFIRMANDO que você vai. Você está afirmando que você quer. Eu vi uma pessoa se arrepender. UMA pessoa se arrepender. Eu sei que são POUQUÍSSIMAS as pessoas que se arrependeram. Esse cara que se arrependeu... que eu vi... (pausa longa), tadinho! Porque diz ele que se 
arrependeu por ter se convertido [à religião]. Entende? Ele se arrependeu ou o fizeram se arrepender? Eu nem o trato no feminino, porque ele se mostra muito "Não sei o que está acontecendo!". Chegaram nele e disseram que eles estava vivendo errado... ele estava feliz, estava de boa! Fazia vinte anos (pausa). Mas é isso... eu acho que se a pessoa... e é por isso que a gente precisa do profissional ali com a gente, porque se a pessoa se arrepender, ele vai precisar tratar do psicológico dele. Da mesma forma que ele correu atrás de toda essa mudança, vai ter que correr atrás de toda outra mudança. Mas acho muito difícil uma pessoa se arrepender de uma mudança dessa, porque a gente teve toda uma análise ANTES de chegar ao ponto de falar "Vou procurar o meu psicólogo!". Tive ANOS! Tive dos doze aos dezesseis anos... pensando nisso... TODOS OS DIAS DA MINHA VIDA, pra chegar à minha mãe e dizer "Mãe, preciso de uma psicóloga." / "Por quê?" / "Porque preciso." E na cabeça, pensando: "Porque sou um homem (pausa) e eu acho isso estranho (pausa) porque me ensinaram a ser mulher.". Entendeu? Foram ANOS, em que TODO MUNDO, TODO TRANS TEM TODOS ESSES ANOS PENSANDO. A gente pensa todos os dias. Aos doze anos, eu comecei a me questionar. Me ensinaram a ser mulher. Eu digo que me ensinaram, porque se você pegar fotos minhas, eu tive um ano feminino, que foi em dois mil e dezesseis. Foi o pior ano da minha vida! Aconteceram coisas horríveis e eu estava numa figura que não era minha, porque me ensinaram a ser mulher. Antes disso, era cabelo curto... no máximo, aqui (aponta para o pescoço) bagunçado, tudo que as pessoas falam que não é de mulher: boné, touca, roupa rasgada, roupa "masculina"... que a minha mãe odiava, mas eu comprava escondido. Daí, em dois mil e dezesseis, eu falei “Tá! Eu vou ser uma mulher!” (pausa longa). Porque, ali, eu já queria mais usar (pausa longa)... a figura que eu tinha antes. Ali, eu já queria mostrar pra todo mundo o Eduardo e eu falei "Eu não posso.”. Então, eu fui radical, porque eu me tornei a minha mãe. Me tornei uma versão mais nova da minha mãe: roupas iguais à da minha mãe, o estilo da minha mãe... e a gente tem um gosto muito igual, então ERA A MINHA MÃE! Nas minhas fotos de dois mil e dezesseis, você vê a minha mãe (pausa longa) e aquilo me sufocou! Me sufocou ao ponto de eu tentar tirar a minha vida! (pausa longa). Minha mãe percebeu que eu estava muito mal porque, na escola, eu chorava do nada nas aulas... Em casa, eu me fechei, eu não saía com mais ninguém, eu não queria mais nada! (emociona-se) Eu não queria pensar em nada! Nem usar o celular. E eu adoro usar o celular. Não fazia nada! (pausa longa). Eu nem ouvia música. Não ouvia música! Todo mundo ouve música. Ouvir música é expressar os sentimentos. Se você não ouve música, você está sem sentimento! Eu não fazia absolutamente nada! Chegava da escola, 
guardava minha cabeça... com todo mundo da sala para cá, o resto para cá (demonstra com as mãos, como se estivesse separando as pessoas) e eu no meio. Abaixava minha cabeça e dormia em todas as aulas. Quando eu acordava, as outras pessoas estavam falando alto demais na minha cabeça, entrava em desespero e chorava, pedia para ir ao banheiro e ficava duas aulas lá chorando. Estava tudo me desesperando. Minha mãe sacou isso. (pausa longa) Mãe é mãe. Mãe sempre sabe. Ela chegou até mim um dia e falou assim "Você quer cortar o cabelo?". O meu cabelo estava aqui (aponta para o meio das costas) e eu nunca tive o cabelo grande só nesse ano. Para fazê-lo crescer mais rápido, eu usei óleo de rícino... para chegar numa imagem mais feminina. Pra isso, também, a minha mãe tinha apostado comigo. Meu cabelo era aqui (nos ombros) e queria cortar em dois mil e quinze... e minha mãe falou assim "Se você deixar seu cabelo crescer abaixo dos seios, te dou cem reais.”. (pausa longa) Oh! Isso mexe com o psicológico! Eu sabia porque ela me queria com o cabelo grande! Ela me queria mais feminina. Deixei crescer, peguei o dinheiro, levei meu irmão pra comer num rodízio japonês. Olha isso! (pausa). Daí, ela percebeu que eu estava infeliz e perguntou "Você quer cortar o cabelo?"... porque eu acho que ela notou depois que ela pediu... Eu comecei a guardar minhas roupas masculinas e usar roupas dela, aí ela começou a comprar roupas. Minha mãe estava feliz! Minha mãe estava MUITO feliz! Eu estava cada vez mais triste. Aí, quando ela falou, eu falei “Quero. Quero cortar o meu cabelo.”, aí eu SORRI... depois de muito tempo! A gente marcou com uma amiga dela... de cortar. Aí, cheguei lá com as fotos do cabelo que eu queria. Eram fotos do Justin Bieber. Ela ficou meio assim de cortar e a gente não cortou. Aí, fiquei triste. Daí, ela falou que, no dia seguinte, iríamos em outra cabelereira. Aí, quando eu cheguei lá com a foto... essa cabelereira já se negou de cortar meu cabelo umas três vezes. Eu falei "É esse corte que eu quero. Se você não quiser cortar, tudo bem, porque tem um barbeiro ali do outro lado.”. Ela falou "Tudo bem, eu corto.”. Ela amarrou o meu cabelo e cortou. Na hora que ela cortou, todo mundo do salão fez “AAAAAH!!! AAAAI!!!” (faz cara de espanto) E eu falei "O cabelo nem é de vocês! Cadê a dor? Olha que bonito! Não é bonito!?”, e elas disseram "Nossa, que é isso??? Você está doido?”. Não consigo me tratar no feminino, nem no passado! Aí, a cabelereira falou "Setenta centímetros de cabelo.”. Aí, eu falei "Não é lindo? Vou doar para uma criança que tem câncer.". Aí, todo mundo ficou quieto (pausa longa). Eu, realmente, doei, e ele foi avaliado. Eu doei quinze mil reais para uma criança sem cabelo. Aquilo estava me fazendo bem e ia fazer bem a outra pessoa. Estava me dando muita raiva daquelas mulheres loucas (sorri). A mulher cortou curtinho, não cortou o corte que eu queria. Aí, falei “Ah, está bom. Vou sair daqui 
assim. Pelo menos cortou.". Na semana seguinte, eu fui num barbeiro, com roupas masculinas. Eu não tinha binder, então usava quinhentas camisas. Usava uma camisa que nunca tinha usado, era verde fluorescente. Era uma regata que nunca tinha usado na minha vida. Horrível! Ela era bem apertadinha, então usei ela, outra regata por cima, outra preta, duas camisas de mangas e uma camisa de um amigo meu. Aí fui ao barbeiro com esse meu amigo da camisa. Aí o cara falou "E aí, jovem!”. Aí, meu amigo me chamando de Eduardo, falando da festa que a gente ia nesse dia... O cara cortou e pensei "Meu deus! Esse é o meu cabelo!’. Fiz um topete... que eu queria. Fiquei SUPER FELIZ!!! Fazia muito tempo que eu não ficava feliz. E era só um cabelo, sabe? E minha mãe foi notando... foi notando que aquele cabelo mudou totalmente. Aquele cabelo me fez ter vontade de ir atrás das coisas (pausa longa). Eu fui... ainda que eu tenho muitos picos de emoções diferentes... eu acredito que todo mundo tenha... mas quando mais chego perto de ser aquela imagem que sempre tive de mim... (pausa longa), eu fico MELHOR!!! (pausa longa). Quanto mais traços masculinos vejo em meu corpo... como, por exemplo, voltei pra academia e aqui no meu braço está mais... nossa, super legal! Super bacana! Eu fíco super feliz! Me sito até forte! E eu sou uma vareta... Me sinto muito bem! (pausa longa). E aí, foi desse jeito que eu... notei que dava para ir atrás de minha felicidade... de uma vida minha! (pausa longa). Uma coisa que é importante para a vivência trans é DESTREZA!!! É olhar FIRME e irônico, porque o ser humano não sabe lidar com isso. Quando a gente olha com desdém, a pessoa se fecha. É assim que eu lido com o preconceito: com desdém, com cara de nojo mesmo. A pessoa está atravessando a rua e fica sem jeito, pede até desculpas. Eu falo "Tem que pedir mesmo.", porque esse tipo de gente, e a gente acha o tempo inteiro... esse tipo de gente com preconceito, que já chega te olhando, comentando, ele se acha no direito de invadir o seu espaço. É necessário CARÃO, porque a pessoa sente que fez errado, e ela não quer errar. Eu lido com desdém. Tanto dentro, quanto fora de casa. Meu recado para as pessoas trans e para os profissionais seria: unifiquem um sistema! Todos que trabalham com isso, independente de onde veio, façam uma coisa só! Olhem a gente como pessoas, como VIDAS!!!

Durante nosso encontro, percebi o quanto é difícil afinarmos o que sentimos ao que realmente temos ${ }^{53}$, ao que nos é possível pelo plano da concretude e pelo nosso viver cotidiano

\footnotetext{
${ }^{53}$ O verbo "ter" aparece aqui não no sentido de "posse", mas no sentido de habitar. Segundo Josgrilberg (2013), "Heidegger se utiliza da particularidade da língua alemã que possui duas maneiras diferentes para se referir ao corpo: Körper significa corpo material e Leib comumente traduzido por corpo vivo." (p. 125). Körper, assim,
} 
em meio aos demais humanos que somos e que são. Diferentemente, apontar o humano que "sou" e o humano que "é", é deixarmo-nos levar pelas amarras do que por muito se acreditou na psicologia humanista de haver um self real e um self ideal.

Percebo - e reitero - que não é por este caminho que trilharei minha compreensão, mas me pareceu importante trazer o que me soou a partir do encontro que tive com Eduardo. Ao escutar que ser um homem trans é sinônimo de uma constante luta, me pego pensando por outro lugar. Nunca foi-nos difícil ser um homem, em nossa sociedade branca e ocidental. Difícil sempre foi - e ainda é - sentir que se pode ser um homem, mesmo que não se preencham ditames sociais que convergem para uma empreitada do "macho" de verdade: um modo instituído de ser homem.

A cultura do macho sobre a fêmea sempre foi motivo de uma constante luta do "forte" sobre o "fraco", ou melhor, uma luta fálica fundamentada na ordem (Bento, 2017). Desde criança, viver pela e na masculinidade - e, aqui, escrevo no singular, porque não havia espaço para pensar por outro prisma - era uma constante luta. Lembro-me bem de um dia, na escola, na então primeira série do ensino fundamental, eu com os meus seis anos numa fila para tirar uma fotografia para os pais. Depois de uma sucessão de meninas, eu era o primeiro menino da fila. $\mathrm{O}$ fotógrafo ensinava às meninas algumas poses, a mais utilizada era com as duas mãos juntas, como se tivessem fazendo um movimento de oração, sobre o rosto inclinado para um dos lados. Angelical, eu diria. Percebendo a continuidade nas fotos, chega a minha vez. Repito o mesmo movimento de juntar as mãos em forma de oração e colocar sobre as bochechas gordas e rosadas. Angelical, eu também diria. Mas não.

Não era esperado que um menino fizesse esse gesto. O que era esperado dele era que tirasse sua foto com semblante sério, com queixo para cima, representando o falo: estático, duro, rijo. Não seria preciso, portanto, que o fotógrafo ou professora ensinassem-me como eu devia me portar. Havia uma regra entrelinhas, havia um modelo que ninguém precisaria questionar, só seguir, só ser macho.

Por entre a narrativa de Eduardo, percebo que há esse contratempo a partir de como ele vê que as pessoas o olham. Não se ensina a ser macho, se nasce e depois se reproduz. Este modelo que temos em nossa cultura já diz de uma leitura de poder sobre poder, pois, para as mulheres, isso seria diferente: é preciso que elas aprendam, que alguém as ensine a "ser mulher" - e que ensine a partir do que este mesmo homem constituiu como sendo o modelo, norma, o ideal, apresentando-se como os corpos “dizimados" pela biopolítica.

corresponderia ao corpo orgânico pré-indicativo "homem" ou "mulher", enquanto Leib teria a ver com o ethos humano, a "morada", no sentido de habitar. 
Escreve Agamben (2010) que

A 'politização' na vida nua é a tarefa metafísica por excelência, na qual se decide da humanidade do vivente do homem.... A política existe porque o homem é o vivente que, na linguagem, separa e opõe a si a própria vida nua e, ao mesmo tempo, se mantém em relação com ela numa exclusão inclusiva. (pp. 1516)

A “vida nua" constituiria, na esfera política, algo encobertado pelo poder produzido pelo corpo biopolítico, ou seja, colocando a vida biológica no centro de tudo que é entendido (logo, conduzido) pelo poder da humanidade. Apesar de o autor utilizar do substantivo "homem" como sinônimo de humanidade, não estando acossado a esta discussão de gênero que venho fazendo até aqui, passo a compreender que o notório desalinho da constituição de "homem" como "macho" está implicado nessa lógica - lógica esta que comunga com a exclusão de corpos “menos" favoráveis à vida.

Perseguindo essas questões, encontro a fala "Me ensinaram a ser mulher.... Então eu fui radical, porque eu me tornei a minha mãe. Me tornei uma versão mais nova da minha mãe....", durante a entrevista, e percebo que, por entre este chamamento, as questões de gênero são passadas culturalmente, vividas e repetidas no seu viver cotidiano, como aponta Butler (2015). Assim, compreendo que a vivência ${ }^{54}$ feminina ensinada pela mãe de Eduardo não delegava somente um modo de viver tal qual a ordem de nascimento dele, mas um modo de reproduzir o "ser mulher" por um viés que excluiria outras possibilidades de ser mulher e elegeria um modo forçoso de feminilidade.

Entretanto, "a gente não nasce nem homem e nem mulher,... a gente se constrói.", o que vai de encontro com a narrativa de Joyce, ao dizer que se "nasce travesti". Considero importante a tematização de Eduardo para pensarmos o "tornar-se homem”. Ser homem, em nossa cultura, é, em todo momento, estar ameaçado por diversas circunstâncias que permeiam o campo da masculinidade compulsória.

Assim, pela experiência de Eduardo ser e tornar-se Eduardo, o receio em sair de casa aparece como legítimo. Deflagrado pelos olhares alheios, olhares que nem o conhecem, mas conhecem sobre o que é ser um "homem de verdade", Eduardo traz a ameaça de uma lógica formal para seu corpo: não é o corpo que ele quer, não é o corpo que ele habita, não é o corpo com o qual ele se identifica. Aqui, questiono: a identificação do corpo masculino teria, portanto,

\footnotetext{
${ }^{54}$ Considero importante fazer uma distinção entre vivência e experiência. Para Benjamin (2012), a vivência implica num acontecimento vivido, que "se encerra" no choque do acontecido, sem estar implicado com o sentido; enquanto a experiência demarca a implicação com o acontecimento, possibilitando a construção de sentido para uma possível historiobiografia.
} 
relação com o modelo criado pelo próprio homem ocidental? De fato, essa resposta poderia ser "sim", mas questiono se ela seria legítima para quem vive um corpo na sua justa medida.

"Eles vão te olhar, sempre, querendo te analisar pra descobrir o quê que você é, sendo que é bem mais fácil perguntar o nome da pessoa." sinaliza o quanto a curiosidade em torno do corpo do outro é maior que a possibilidade de curiosidade sobre quem ela é. Talvez, para ele, no seu modo fronteiriço, esta referência de perguntar sobre seu nome não abria a possibilidade de se dizer quem é simplesmente.

Ao fazer uma crítica do mundo ocidental, Heidegger $(2011,2012)$ discute a questão a do mundo da aparência. Para ele, o arsenal de técnicas científicas, bem como os saberes construídos no mundo ocidental, acabou tomando as coisas pela aparência que elas apresentam e não pelo que, de fato, são. Neste sentido, podemos também compreender e empreender um sentido para o corpo, pois, assim como as noções de "causa-efeito", "objeto-instrumento", "saúde-doença", o corpo passa por uma demarcação fincada na naturalidade de um envoltório material.

A figura do corpo é questionada pela sua amorfia, dismorfia, eficiência, deficiência, anormalidade, estranheza... o olhar que acusa - e recusa - a figura carnal ${ }^{55}$ do outro é o mesmo que o culpabiliza pelas escolhas de lidar com o corpo pelo prisma da cientificidade que está em todos nós (acadêmicos, intelectuais, cientistas, religiosos e leigos). O olhar desnuda a impossibilidade alheia, delimita o lugar objetivo em que cada corpo pode transitar delimitando, inclusive, até por onde ele pode ir com seu nomadismo aparente.

Esse olhar intrusivo é, ao mesmo tempo, demarcador de uma intrusão do próprio corpo que, no caso de homens trans, volta-se para "partes" do corpo anatômico que não condizem com sua generidade. Eduardo frisa o incômodo em torno dos seios ${ }^{56} \operatorname{como~intrusos~}^{57}$. Em outras atestações de trans-masculinidades ${ }^{58}$, a experiência em torno dos intrusos é sentida não somente pela presença de seios (que representam, muitas vezes, a primeira necessidade de "se livrar"

\footnotetext{
${ }^{55} \mathrm{~A}$ ser discutido mais à frente, quando da referência sobre que o corpo-carne, enquanto matéria, é assumido pela medicina ocidental.

${ }^{56}$ Num primeiro momento, escrevi "seus seios", mas depois questionei se os seios seriam dele mesmo, faziam parte de sua conjuntura existencial de "ser Eduardo". Também pensei em chamar de "mamas", mas do mesmo modo compreendo que o vocábulo não empreende este sentido funcional. Aqui, reafirmo que o "corpo que sou" não dá conta de uma Existencialidade, ao mesmo tempo em que nos tira do lugar de assimilação, identificação e consonância sobre o corpo que pensamos como o "ideal" e o corpo que vemos como o "real", focando, mais uma vez, em uma deflagração, mensuração intrusiva e fragmentação de um corpo alheio, abjeto. Afinal, há espaço para pensar um corpo senão pelo prisma anátomo-funcional? E se não há espaço, pensando por este prisma, poderíamos dizer que, neste caso, este "órgão" ou "parte" de corpo seria "funcional" em relação ao modo de Eduardo existir?

${ }^{57}$ Homens trans, comumente, chamam estes órgãos que dissonam de sua identidade de gênero como intrusos.

${ }^{58}$ Este termo evidencia o que o próprio movimento de homens trans vem discutindo acerca da construção de uma identidade de gênero, frisando o vocábulo trans anterior ao ser masculino.
} 
cirurgicamente), mas também para os órgãos sexuais, órgãos reprodutores (ovários, trompas e úteros) e a menstruação.

Seguindo pela narrativa de Eduardo, estas considerações são pontuadas em sua experiência, especialmente no que diz respeito ao modo como profissionais de saúde - em especial médicos e psicólogos - endereçam práticas a partir da pré-construção subjetiva do que seria "corpo de homem" e "corpo de mulher". Diz ele:

Pra ir lá no endócrino [médico], com todos os laudos pra mostrar... com OITOCENTAS PESSOAS atrás de mim dizendo 'EU ACREDITO QUE ESSA PESSOA É TRANS!!!'. EU sou trans, não é VOCÊ!!!! EU JÁ ESTOU DIZENDO QUE SOU TRANS! EU ESTOU DIZENDO QUE QUERO MODIFICAR MEU CORPO, QUE QUERO MODIFICAR MINHA VIVÊNCIA SOCIAL!!!

Indo pelo caminho do apelo através desta narrativa, começo a refletir como seria possível pensar práticas em saúde a partir de outra dimensão que não voltada apenas a estes órgãos como sinônimo de reprodução e subsistência do ser "fêmea" biologicamente para o homem trans. Este caminho que penso volta-se, principalmente, às práticas de ginecologia, uma vez que homens trans também necessitam de cuidados preventivos em torno de sua genitália. Julgo esta pontuação como importante, pois os cuidados preventivos que giram em torno do câncer do colo do útero e do câncer de mamas devem ser, também, direcionados a homens trans que convivem com tais órgãos.

Este fato ainda traz outra questão que durante minha experiência com a população $\mathrm{T}$ e com profissionais de saúde que lidam com esta população ficou evidente: se exames como estes são dolorosos e incômodos para mulheres cis - sem falar nos processos violentos e abusivos sofridos contra as mulheres, por parte de médicos e médicas durante exames ginecológicos imaginemos para um homem trans, que reconhecendo a intrusão de tais órgãos, também sofrem mais uma intrusão sobre e no seu corpo...

De fato, é preciso pensarmos sobre práticas de cuidado para esta população em específico, não só porque a saúde, do ponto de vista científico e profissional, reconhece o corpo como uma matéria que pode ser de-composta, mas também porque é preciso fortalecer uma rede de cuidado e direcionar reflexões para a prática cotidiana. Como pensar saúde do "homem" neste sentido?

A utilização de binders (faixa que aperta os seios para comprimi-los e deixá-los o mais rente possível ao tronco), coletes cirúrgicos e blusas folgadas ou blusa sobre blusa são, recorrentemente, alternativas para homens trans que sentem os seios como intrusos e que ainda não recorreram à cirurgia de mastoplastia masculinizadora. 
Há a importância de falar que, em nosso modelo de saúde e na política de saúde, voltada ao processo transexualizador no SUS, a mastoplastia é um direito do homem trans, porém ainda é pouco disseminada nos centros de saúde que atendem a esta população. Do ponto de vista das identidades de homens trans, a remoção dos seios é um dos primeiros passos para a afirmação e reconhecimento de um corpo que condiz com um gênero masculino, possibilitando a atestação da liberdade de ser quem se é, habitando o mundo a partir de um corpo habitado e não apenas vivido.

Entretanto, "Quando não conseguem ver no seu rosto, na camisa, olham na calça, porque homem é pênis! Esse é o reduto de um homem!". O "reduto" do homem, em uma sociedade heteronormativa e machista por condição histórica, aproxima-se de um ideal fálico, como já falado anteriormente, que deflagra uma estrutura corpórea para o homem trans. Atualmente, no que se refere a cirurgias de transgenitalização-masculina, esta realidade ainda é considerada "experimental” pelo próprio SUS e poucos são os centros especializados no processo transexualizador que atendem a esta procura específica.

A utilização de packers e/ou outros meios de criar uma "prótese" peniana, na experiência de Eduardo, é uma realidade apenas na esfera sexual, porém que tangencia também uma aparência de "definição sexual". "Só que ele me faz falta na parte de quando a pessoa vai me analisar e fica olhando tudo e fica... pra baixo". Para Eduardo, o olhar de atestação alheio sinaliza se seu corpo é de “homem ou mulher!", o que Araújo (2016), Bento (2017a, 2017b) e Leite Jr. (2011) tematizam como "a verdade sobre os sexos".

Tal atestação, de fato, não diz somente do olhar alheio/curioso de pessoas aleatórias que, evidentemente, estão formadas por um pensamento arraigado fundamentalmente na ordem vigente patriarcal. Estes olhares de atestação perpassam, inclusive, a prática de profissionais de saúde que, a partir do órgão genital, realizam sua leitura e ação: neste caso, se sai de um plano de uma clínica estética para uma clínica da forma, que reforma e nega esta construção de corpo. Ou seja, tal clínica fundamenta-se na ausência-presença de um órgão como prova real e viva de uma categorização homem ou mulher.

Nesta direção, amparado por uma lógica de construção de corpo e de identidade a partir do experienciado e autenticado socialmente, o campo das masculinidades entra em cena para situar diversos modos de ser "masculino", modos estes que saem de uma alocação da categoria homem, biologicamente falando, para uma categoria que é construída a partir das relações estabelecidas. Assim, as masculinidades reverberam como possibilidades de construir um sentido possível que diverge de uma confirmação que dado comportamento tipificado como masculino deveria ser associado a um "verdadeiro homem". 
Assim, "Quanto mais rude, pra sociedade, mais homem. E eu não sou assim. Eu não me identifico como mulher, mas sou um homem delicado, digamos assim. Mas eu não posso! Porque aí que as pessoas vão falar "Mulher!", e eu não quero ser visto como mulher!". Ou seja, ser "masculino" se enquadraria justamente nesta não-conformidade com a ordem vigente de nascimento, dialogando com a noção "máscula" da qual a sociedade ocidental foi embebecida.

Esta especificidade de masculino/feminino, por muito, esteve associada à uma compreensão dada e inata de homem e mulher. Sua notória não-conformidade, enquanto comportamento social, era direcionada a uma orientação sexual que não condizia com a norma, ou seja, um homem "não-masculino" seria encaixado como homossexual, ao passo que seu comportamento social "um tanto feminino" era colocado em xeque como uma masculinidade frágil para outros.

Neste sentido, entendo que, quando Eduardo apropria-se do termo "viado" para tratar de seu modo de ser um homem trans, fica imbuído que a norma consideraria seu modo de ser como feminino e, portanto, estaria associado à feminilidade. Aqui, novamente questiono as (im)possibilidades de tornar necessária a consideração de padrão feminino e masculino, considerando, inclusive, reflexões do movimento Queer $^{59}$.

A partir disto, parece-me ficar evidente que esta compreensão de homem e mulher, tal qual estamos discutindo, só foi possível na medida em que os conceitos de orientação sexual e gênero fossem dissociados, sendo estudados e compreendidos a partir de suas diferenciações e conexões com a existência humana. Por esta via, penso que, fenomenologicamente empreendidos pela compreensão de Dasein heideggeriana, há como fazer uma distinção dos variados modos que Dasein pode se mostrar no mundo. Se somos seres de possibilidade, articulando à lógica de pro-jecto, não estaríamos, pois, fadados a experienciar nosso corpo, gênero e orientação sexual sem, necessariamente, encaixarmo-nos num "padrão" Dasein "vivenciado" pela determinação de nascimento?

\footnotetext{
${ }^{59}$ Miskolci (2013) considera o termo Queer como uma reformulação de seu sentido originário ("estranho", "diferente"). Durante a década de 80, nos Estados Unidos, foi um movimento importante para a população LGBTI (inclusive, após discussões e reflexões do movimento, a letra Q passa a ser incorporada, tornando-se LGBTQIA+, atualmente - lésbicas, gays, bissexuais, transgêneros, queer, pessoas intersexuais, assexuais e outras atestações de gênero e orientações sexuais). Com o passar do tempo, o termo queer, que antes era carregado de sentido negativo, começa a ser utilizado como uma forma de reconhecimento de identidades construídas à margem da heteronorma. No Brasil, termos como "bicha", "viado" e "sapatão" eram, anteriormente, associados ao escárnio, desrespeito e de natureza pejorativa. Hoje, o movimento LGBTI demarca tais termos como construções fundamentais para pensar feminilidades e masculinidades, ancoradas às próprias experiências de identidades que escapam da lógica causal.
} 
O que presumo é que, fenomenologicamente, não teria como compreender homem/mulher senão via experiência de ser homem e ser mulher. Compreender o gênero a partir de pressupostos conceituais-positivistas voltados para diagramação de uma vivência seria não se atentar ao próprio pro-jecto de ser homem e ser mulher, ou seja, não se destinaria à existência no-mundo-com-outros, negando seu próprio corporar como Existencialidade.

Em trabalho anterior (Melo, 2015), tematizo como as noções de corpo configuradas à permanência da ordem natural e material aprisionam a compreensão que fazemos dos corposno-mundo. No que diz respeito ao corpo vivido - como falado anteriormente - encontro em Heidegger (2009) um sentido possível de fazer aproximações. É importante tematizar que o que o filósofo compreende por corporar, segundo Melo (2015), refere-se à consideração de que

O corpo é 'meu corpo', não pode ser considerado a partir do limite imposto ao corpo material que ocupa um lugar determinado fisicamente no espaço e no tempo. $\mathrm{O}$ modo como experiencio o meu corpo faz parte do fenômeno corpo, está relacionado a minha experiência e não pode ser reduzido a um corpo material, objeto de estudo das ciências da natureza. (p. 49)

Ou seja, o corporar refere-se à compreensibilidade do corpo enquanto existência, habitação. Para Josgrilberg (2013), o mundo circundante (com o qual lidamos e vivemos) acabou por se perder, se dispersar e desaparecer, dissolvendo o corpo em sua corporeidade, ou, dito de outra maneira, o corpo enquanto existência, fazendo com que a maneira mais acessível ${ }^{60}$ seja o modo tradicional, determinado pela ciência da natureza, de compreendê-lo.

Assim, o mundo passa a se perder junto, uma vez que busca sustentar, em sua totalidade, as referências que lhe cabe em detrimento do "manejo" e serventia que o corpo passa a ter com o tempo (como o corpo para o trabalho e as guerras, por exemplo). Nesse sentido, a concepção de corpo refletida para cada situação tem a ver, necessariamente, com a visão de homem e mundo previamente compreendida.

Perseguindo esta compreensão, toda compreensão em fenomenologia voltada para os estudos de gênero deveria levar em consideração seus próprios pressupostos compreensivos, que são evidenciados em toda e qualquer atitude clínica em prol de uma ação que é delegada às singularidades em meio ao plural da existência. Só seria possível, a partir de minha compreensão de ser psicólogo junto às singularidades trans e travestis, uma ação clínica em

\footnotetext{
${ }^{60}$ Não que seja a maneira errada, mas que é um modo de pensar o corpo que, em nossa compreensão, o apreende e o deixa sem possibilidades de existir enquanto fundamentalmente atuante, tornando-o frágil e enclausurado em si mesmo.
} 
psicologia se ela partir da compreensão conjunta do que se compreende por existência sem desvinculá-la ao viver cotidiano. Por esse e tantos outros motivos é que compreendo que a pergunta "Como falar de gênero na perspectiva fenomenológica existencial?", feita anteriormente, não faz sentido algum.

A partir deste percurso, atentando-se a especificidades das existências trans, percebo que a prática em psicologia deve orientar-se por uma dimensão que intercruze saúde e educação. Como já falado anteriormente, a formação em psicologia prioriza disciplinas que "psicologizam" a vida, muito mais do que em disciplinas que conversem com experiências vividas-no-mundo-com-outros.

Dialogando com esta dimensão, não somente a psicologia, mas diversas disciplinas do campo da saúde acabam recapitulando ideais normativos para medicar, curar, consertar e delinear práticas e saberes que perpassam a trajetória de seus sujeitos-objetos. Tais práticas, camufladas pelo olhar do crivo científico que molda e decompõe seus próprios sujeitos, regulamentam toda uma estrutura do próprio conceito de saúde e de educação vigentes.

A saúde, empreendida pelo sentido da Organização Mundial de Saúde (OMS), estaria atentando para este pleno estado de bem-estar (fragmentador e descentralizador) físico, psicológico e social? Nesta direção, a educação, objetivada pela Organização das Nações Unidas (ONU), estaria assegurando uma educação equitativa, inclusiva e de qualidade para seus sujeitos? Penso que tais "certezas" moduladas por estas organizações, além de não garantidas pelo Estado, não fazem sentido em meio ao arsenal do direito às diversas existências, principalmente se considerarmos as minorias - em especial as latino-americanas ${ }^{61}$.

No campo da educação, o apagamento do gênero é relacionado à ordem reprodutiva. Estuda-se, desde a mais tenra idade, que um corpo é composto por cabeça, tronco e membros superiores e inferiores e, mais à frente, que estas partes compõem diversos sistemas. Os sistemas são entendidos como um conjunto de órgãos que têm características próprias e papeis claros para cada corpo. A reprodução deste corpo é necessária para a produção de novos corpos.

É por este motivo que penso que o termo genitália abarca maior aproximação com tais conjuntos de órgãos que formam estes sistemas, muito mais que apenas um "órgão reprodutor". Por muito - e talvez até hoje - desde o ensino fundamental, ensina(va)-se às crianças sobre os "aparelhos reprodutores" como um complexo formal para o conjunto de órgãos que formam as genitálias femininas e masculinas. O processo educativo já vem arraigado de um discurso que

\footnotetext{
${ }^{61}$ Tal questão será discutida em capítulos posteriores.
} 
permeia este pensamento ocidental vigente e acaba perfazendo uma ordem diretiva para os corpos alheios. Estes órgãos foram feitos com uma única e exclusiva tarefa: reproduzir.

Aventurando por esta lógica, é nítido que o processo educativo formal, principalmente no que tange à educação infantil, ainda é formalizado e construído a partir de condicionamentos do Estado (laico?), que direciona práticas que, para além de serem discutidas na esfera pública, passam a ser vividas no seio privado da família tradicional nuclear-burguesa. Este pensamento e essas práticas acabam por dirimir as lutas em torno de um corpo, além de subsidiarem condutas sobre o direito de se ter - e viver - um corpo, tal como Agamben (2010) constrói reflexões.

Penso que é por este motivo que as práticas em educação e saúde ainda priorizam este discurso, reverberando nos movimentos - em especial, o feminismo e o movimento LGBTI mais um apagamento sobre e de suas lutas. Há necessidade de se questionar se tais direitos do corpo (ou seria da vida humana?), em meio a este arsenal, servem para a vida (pro)criada ou para a vida ser vivida.

Na esfera pública, os corpos passam a ser julgados pela sua materialidade, sendo exposta a vida vivida, "Eu sou uma exposição, sabe? Não sei se você já ouviu falar dos zoológicos humanos... eu me sinto muito uma exposição humana!". Caminhando por esta direção, percebo que a intromissão do olhar alheio para o corpo do homem trans representa, para Eduardo, algo similar aos famosos “zoológicos humanos", que aconteciam no início do século XX, na Europa. Esses "zoológicos" eram depositários de pessoas negras, índias, pessoas com deficiências inúmeras, siameses, intersexuais (que até a pouco eram chamados de "hermafroditas"), entre outras variações "fora da norma" do que seria um corpo humano perfeito/normal. Por entre estes olhares intrusos, muitos homens trans recorrem a algumas alternativas de esconderem seu corpo - ou melhor, de esconderem um corpo que não condiz com o seu gênero e nem com o julgamento alheio.

Vamos adiante pela narrativa de Eduardo. "justamente porque como nós vamos ser professores, temos que entender que na sala de aula vai ter todo tipo de aluno. O aluno passa mais tempo na sala de aula do que na própria casa, entendeu? Então, nós participamos bastante da criação desses alunos!". É curioso que o olhar de Eduardo para esta questão afinase ao que se vem discutindo sobre a formação no ensino superior em torno da necessidade ou não de incorporar uma disciplina que priorize somente estas questões das generidades e sexualidades ao currículo dos diversos cursos, principalmente dos que se voltam ao campo da saúde e da educação. 
Eduardo fala: “Alguns [alunos] falam 'Tá, se aborda tudo... mas o que isso tem a ver com História?' e os professores 'TUDO a ver com HISTÓRIA!!!'. Isso aqui é História!’. Não somente é história como permite com que a história seja construída. Neste sentido, a discussão com relação à inserção de disciplina sobre transexualidades e travestilidades em currículos de qualquer formação precisa ser olhada atentamente. De um lado, uma disciplina que abrisse este diálogo não estaria focando uma particularidade específica e direcionando uma prática para "um modo de fazer"? Ou seja, seria preciso formar "especialistas" neste assunto? De outro lado, trabalhar estas questões na formação, em qualquer que seja a disciplina, não poderia inaugurar outra reflexão para estas práticas quando direcionadas pelo olhar de quem doutrina?

Chamo atenção para "nós participamos bastante da criação desses alunos!" e penso que tipo de criação o(a) professor(a) promove em suas práticas cotidianas. Ao escutar isto de Eduardo, começo a pensar o sentido de educação. Etimologicamente, a palavra "educação" vem do latim educare, vocábulo ligado a educere, um verbo composto de ex (fora) + ducere (conduzir, levar). Literalmente, a palavra educação, portanto, teria o sentido de "conduzir para fora" ou "a diante".

Conduzindo para fora, talvez, teria o sentido de destinar uma prática política, norteada por compreensões conjuntas sobre um fazer que dê sentido a um saber, ou seja, dialoga com concepções que encaram a vida cotidiana como uma ponte para, em se fazendo transeunteviajante, poder ser. Tal ponte que liga o fazer e o saber como aproximáveis pode inaugurar ações que descortinam a possibilidade de mobilizar significados outros e um sentido consentido para estas mesmas práticas. Destarte, esta possibilidade de educação só é possível se articulada com nuances que saem do campo de uma noção de currículo formal para uma vertente que garanta a liberdade de saber de seus próprios educandos.

No entanto, a escola de hoje ainda não está preparada para receber minorias (Miskolci, 2013). Diariamente, a escola é a principal fábrica de corpos que dialogam com a norma (Araújo, 2016; Louro, 2015), revelando que é um espaço de descuidado, desestímulo e despreparo. Focando-se única e exclusivamente na formação curricular a partir de diretrizes, acaba por rechaçar e indicar quais corpos viverão à margem, quais corpos são abjetos.

A partir do lugar de narrador, testemunhado e testemunhando a narrativa de Eduardo, além da experiência com singularidades trans, compreendo que a escola, mesmo que pública, não é um espaço público no sentido originário do termo. Nela, não há espaço para as diversas existências transitarem, muito menos as que fogem de um modelo normativo de corpo, gênero ou sexualidade. Reitero que o sistema escolar sempre se mostrou excludente, mesmo que à 
surdina. Na fala de Eduardo, é evidente como a instituição escolar prioriza a necessidade de vigiar e punir, muito mais do que "conduzir para fora".

Para as identidades gays, lésbicas, bissexuais, transexuais, travestis e intersexuais, o espaço garantido de fala, nessas instituições, é o espaço do escárnio, do desrespeito, da inexistência e da impossibilidade de ser quem se é por vigorar um "modelo" de educação que é falho e não se atenta às peculiaridades. Talvez sobre, sim, para alguns e algumas, um "conduzir para fora", mas como Fernanda falou em nosso encontro: pela via da expulsão e da repulsa indiciada pelo próprio sistema.

A ex-pulsão pelo sistema fortalece um discurso que amarra muitas práticas em educação e que, atualmente, vêm sendo discutidas na esfera pública. Quando Eduardo fala "Eu sempre fui bastante resistente a qualquer tipo de injustiça... Não me calava. Jamais me calo em nenhuma circunstância.", claramente entendo que o lugar da existência em ser LGBTI vem atrelado à re-sistência ${ }^{62}$. Re-sistir às amarras sociais, excludentes, massificadoras e conservadoras denotam uma possibilidade de ação política.

Mas a re-sistência também pode se mostrar por um lado inverso. A instituição escolar, não estando preparada para lidar direta ou indiretamente com as existências trans, institui uma afirmação e recusa de corpos e singularidades. Isso faz com que, inclusive, os próprios existentes não entendam quem são e não sejam legitimados enquanto existências na esfera pública.

Quando Eduardo narra "Se eu já tinha toda uma luta por me relacionar com alguém do mesmo sexo - e, por sexo, eu digo genital - que eu, não via nenhuma brecha em que eu pudesse dizer 'Sou um homem trans.' aí foi o que mudou toda minha vida lá [na escola].”, compreendo que, nessa época, sentia sua identidade como algo que deveria ser encoberto e engavetado na escola, sobrando o espaço de sua condição como lésbica. Percebo que a condição de lésbica, neste caso, estaria associada muito mais a um órgão genital (sexo, como Eduardo fala) do que à condição de ser mulher, aos olhos dos outros e da instituição. Ou seja, mesmo que sobrasse este lugar "menos angustiante" para Eduardo (ou para a escola), de poder voltar seu desejo para mulheres, sobrava um espaço que não dava conta de sua sexualidade, sua construção de corpo e sua identidade de gênero, revelando mais um apagamento.

Indo adiante, ele cita a família como um dos principais apoios necessários para fortalecimento e resistência ${ }^{63}$ : "antes até que eu conseguiria ter uma vida masculina na escola, caso eu tivesse visto essa abertura pra me relacionar com minha família antes, porque como

\footnotetext{
${ }^{62}$ Voltar a existir.

${ }^{63}$ Apesar das dificuldades de sua mãe quanto à sua transição.
} 
eu não tinha apoio da família, não tinha como.”. Esta sinalização, também evidenciada por Joyce e Fernanda, demonstra o quão a família ainda transforma as singularidades trans como instituídas, apagadas pela privatização de uma existência que parece nunca ser também seu próprio corpo.

Parece-me importante pensar a questão da família no que tange às experiências de transgeneridades, justamente porque os modelos de família vigentes ainda são formados pela mesma ordem da via pela qual a educação formal se destina. Na esfera privada, no âmbito do lar, ensina-se a ser homem e ser mulher, e este modelo é reproduzido por quem direciona as práticas instituídas da educação formal. Entre a via de ser homem e ser mulher, para muitas famílias, ainda existe a legitimidade de uma existência focada no "bem", direcionando o homem e a mulher para a perpetuação familiar: exercer a cidadania como homem de bem e mulher de bem para formar uma sociedade de bem na esfera pública.

Eduardo, quando fala sobre sua mãe, diz "ela chegou a conversar comigo umas quatro vezes, em quatro épocas diferentes da minha vida, falando que, se eu quisesse ser homem, ela deixaria de ser minha mãe, me expulsaria de casa". Sinaliza como a convivência familiar confabulou e privatizou sua existência, tornando-a privada em sua aparição, evidenciando como a participação de sua mãe sobre sua condição, sua singularidade e suas escolhas deveriam ser compulsórias. Tal compulsoriedade traz certa conotação: de um lado, sinaliza a impossibilidade de haver um "Eduardo filho" (e logo, de haver uma mãe na história), e, de outro, sinaliza a obrigatoriedade de viver por um prisma que não lhe diz respeito.

Aqui, lembro minha experiência como gay, ao contar à minha mãe, aos tenros quinze anos sobre minha sexualidade. Pelos escombros do vazio, da solidão, do desespero e do embaraço em ser algo que ainda não tinha clareza do que era, e só saber o que era a partir do que diziam sobre o que era, é imprescindível pensar, também, que o assombro da família é legítimo. É legítimo, pois tal assombro, por parte de quem passa pelo caminho de ser educado para o "armário", também diz do modo de se produzir sexualidade como exclusivamente focado na esfera sexual - de um lado, o sexo destinado para a reprodução; de outro, o sexo que vai pela via da promiscuidade.

Entendo, evidentemente, que a família não está preparada para lidar com tais questões, ainda mais porque, em nossa sociedade e cultura, seguimos embebecidos pelas couraças do patriarcado. Na narrativa de Eduardo, percebo um peso em se cobrar por sua identidadeexistência e que é necessário pensar o lugar e a participação da família para se tornar o dono da voz. "ela [a mãe] chegou a dizer que preferiria me ver morto que mudando todo meu corpo.... Isso foi bloqueando tudo em mim! Foi me assustando, foi me dando medo de querer viver.". 
O "medo de querer viver" vai contra o "conduzir para fora do armário", pois sinaliza a recusa de viver conforme o que the foi estabelecido e determinado. Encontro esta recusa da mãe de Eduardo mais fortemente quando ele fala "Não importa quantas vezes minha mãe diz que ela quer participar... ELA NÃO QUER, de fato!!! Porque toda vez que há um passo a mais pra eu dar, ela recua DEZ, entendeu? [...] É PÉSSIMO!!!".

Durante a escritura da tese, vi uma foto no Instagram" com os dizeres "Tetris me ensinou que quando você tenta se encaixar você desaparece.", e percebo como esta frase tem relação com a fala de Eduardo sobre seu "medo de querer viver". O jogo tetris, pensado como uma construção feita por tijolos que se encaixam entre si, parece ser uma metáfora do corpo trans e do corpo travesti - querer viver num corpo que não lhe diz respeito abre duas possibilidades: 1) burlar o sistema de encaixe e garantir game over; 2) encaixar-se pelas peças e desaparecer.

Por entre o burlar o sistema e encaixar-se em prol de um desaparecimento, encontro, também na fala de Eduardo, a burocracia do sistema de saúde e da própria psicologia enquanto profissão. Durante nosso encontro, questionava-me qual o lugar do(a) psicólogo(a) ao the ser solicitado uma escuta ou pedido de uma pessoa trans. A fala "Eu já tenho [...] um ano e sete meses em terapia [...]" leva-me pela mão. Conforme estabelecido pela Portaria do Processo Transexualizador no SUS (Portaria $\mathrm{n}^{\mathrm{o}} 457$, de agosto de 2008), cabe ao(à) psicólogo(a) acompanhar durante dois anos a pessoa transexual, no que tange às cirurgias de redesignação sexual. A portaria, não deixando claro de que modo deve ser feito este acompanhamento, acaba dando indícios ao(à) profissional de psicologia ter posse sobre a modalidade de prática de sua preferência. Assim, o(a) psicólogo(a), elitista de formação, elege a psicoterapia como sendo o mote central de sua ação, determinando uma vigilância compulsória de um corpo e de uma identidade de gênero semanalmente (Galli \& Vieira, 2013; Oliveira, 2014).

Este res-guardo da profissão de psicólogo(a) encaminha-nos a inúmeras discussões, inclusive em relação à nossa própria formação que, como qualquer outra, tem suas amarras em torno de um currículo falho e que não atenta às minorias. Aliás, o currículo dos cursos de psicologia, mesmo que dialogue com práticas que saem do imaginário de um setting terapêutico pré-configurado, ainda não se mostra, muitas vezes, preparado para permear práticas de cuidado que destinem à vida cotidiana, dando maior ênfase a teorias e certezas científicas.

Que psicologia nós estamos construindo? Que "sujeito psicológico" estamos produzindo? Que discurso estamos reificando como modelo de construção de verdades? Penso

\footnotetext{
${ }^{64}$ Rede social que é focada em postagens de fotografias.
} 
que é preciso fazer um caminho in-verso: atentar a nossas práticas e refazê-las, antes de determinarmos quais sujeitos buscamos produzir, quais discursos veracizar e qual psicologia requerer.

Julgo importante esta reflexão não somente para firmarmos nosso lugar enquanto uma ciência e profissão que tem participação efetiva na história do país, mas também por ser uma profissão que deve lançar suas práticas conjuntamente com sua clientela, implicando uma ação política no seu fazer. Tal reflexão, inclusive, é trazida por Eduardo, quando ele fala "Não é porque... que eu preciso de minha psicóloga pra eu ter CERTEZA de quem eu sou. Eu preciso dela porque eu quero chegar nela e dizer assim 'Olha, hoje tentaram me matar! O que eu faço?', entendeu? É pra ISSO que eu preciso de uma psicóloga.”.

Atrelada a esta fala, encontro outro trecho da entrevista: "EU JÁ ESTOU DIZENDO QUE SOU TRANS! EU ESTOU DIZENDO QUE QUERO MODIFICAR MEU CORPO, QUE QUERO MODIFICAR MINHA VIVENNCIA SOCIAL!!!". As duas falas em questão dizem da complexidade da experiência vivida pelo outro. Ao que parece, a psicologia, em especial nos espaços institucionais que são mergulhados pelo preenchimento de laudos técnicos, depara-se com intercruzamento ou de resguardar-se enquanto profissional ou de dizer sobre o corpo do outro (Melo, 2015).

"Eu acho que os profissionais têm que estar aqui pra ajudar a gente na questão do viver!". Compreendo, a partir da narrativa de Eduardo, que o lugar da psicologia, nestes casos, seria o de acompanhar e esclarecer demandas do próprio viver cotidiano, muito mais do que focar, apenas, na invenção científica do que seria a transexualidade. Penso que atender a um pedido de uma clientela que clama por uma despatologização de sua existência a partir de um prisma que a massifica, já é, por si só, não endereçar uma ação clínica. Aqui questiono: Seria necessário que o(a) profissional "entendesse" sobre a temática da transexualidade para atender tal demanda específica? Até que ponto, nós, psicólogas e psicólogos, não estaríamos priorizando o pedido e a queixa, contemplando uma demanda que não é do outro, mas que é nossa?

Apesar de, na entrevista de Eduardo, ficar claro que tipo de acompanhamento os(as) psicólogos e psiquiatras precisariam fazer aos atendimentos dirigidos a pessoas trans, encontro algo que, a partir de sua experiência, aproxima-se destas questões anteriores. Ele fala "nem cobro de TODOS os psicólogos saberem atender esse público.... Mas, eu digo que... seria legal que todos estivessem cientes que existe... Talvez a demora no laudo venha disso... Acho que a questão de não ser um especialista, pode atrasar.". 
Mais adiante, estas questões parecem na entrevista dirigidas à composição dos laudos e pareceres “no laudo dela [da psicóloga], está assim 'Eduardo afirma...', 'Eduardo DIZ querer... '... ela não afirma NADA.... Já o laudo da psiquiatra está dizendo... 'Eduardo tem uma vivência de um homem transgênero...', ela estava afirmando coisa dela. 'Percebo que ele está propício a usar o nome em tal instituição...' Sabe?".

Compreendo, a partir destas falas, que talvez o seu incômodo origina-se no que compreende ser a necessidade do profissional apontar a fala do cliente no processo para responder às questões burocráticas (laudos, pareceres, entre ouros documentos solicitados para retificar o corpo em conformidade com o gênero), ao invés de acompanhar por qualquer modalidade de prática aquele(a) que o procurou.

A comparação relacionada entre a psicóloga que o atendeu anteriormente e a psiquiatra que é especialista em sexualidade mostra a importância de, além de saber que existe, saber o que é a transexualidade. Para ele, seria muito mais importante que o profissional colocasse e afirmasse sua compreensão acerca do sentido da experiência transexual desta existência.

Fica evidente que, para ele, é preciso que o profissional de saúde se dirija ao(à) usuário(a) do serviço e fale com ele, acerca dele e não somente sobre ele. Ou seja, que o profissional se apresente como clínico, inclinando-se na direção de um cuidar compartilhado (Morato, 2018). Aqui, parece-me notório que tais práticas ainda se dirigem pelo crivo da tecnicidade, delegando para si o direito e o saber sobre o outro, reverberando um distanciamento em relação ao outro, a ele mesmo, à sua prática e ao seu compromisso ético-político (Bento, 2017).

Enquanto psicólogo, escutar falas como estas de clientelas, especialmente de minorias, me dói e me envergonha. Entendo a necessidade do parecer ou do laudo psicológico para tais questões, dado o sistema estrutural atual em que vivemos; mas, ao mesmo tempo, questiono tal necessidade quando colocamos sobre o outro um atestado de sua (in)existência, produzindo um discurso teórico-subjetivo que nem o outro e nem o próprio profissional compreendem, pois não se dirigem pela via da experiência. Aqui, lembro-me de Benjamim (2012) e reflito nosso lugar de narrador como testemunhador de histórias. Tal agir profissional estaria, de fato, narrando ou informando sobre?

Ainda, caminho pela fala de Eduardo. "Existe machismo na própria população trans. Eu costumo dizer que TODO homem é machista. Seja ele cis, seja ele trans, seja ele hétero, bi, gay, qualquer outra sexualidade... acredito porque... por uma cultura enraizada.". Eduardo aborda aqui outra questão: o machismo. Como já falado anteriormente, o modelo patriarcal em que vivemos acossa diversas famílias (mesmo que resistentes ao sistema). Para Eduardo, a 
experiência de ser um homem trans implica situações cotidianas que compreendem a alegoria do "verdadeiro homem". Entre elas, destacam-se questões básicas, como, por exemplo, a higiene do packer, sinalizada por ele como um "descuido" do homem cis em relação ao seu corpo $^{65}$.

Em minha prática como psicólogo no Centro de Cidadania LGBTI, pude perceber que o machismo se fazia presente em muitas falas e comportamentos de homens trans. Questiono se este tipo de relação com o mundo não implicaria uma tentativa de "enquadrar-se" no que verdadeiramente entende-se por homem em nossa cultura. Isto por, possivelmente, fazer com que ele tenha "que estar sempre reafirmando pra sociedade que é HOMEM....", apoiando-se nos padrões normativos de corpo, comportamento e, inclusive, desejo.

Seguindo tal reflexão, Eduardo diz "O que percebo de machista nos homens trans é com as próprias mulheres.... É um absurdo, na minha visão, a gente negar a vida que a gente teve antes!... Sempre me senti um homem, mas nem sempre eu FUI um homem, entende?’. Fui extremamente afetado por estas palavras, pois isso passa por um apagamento que a nossa cultura delega a estas existências, como se não fosse possível pensar sobre o corpo que vivemos, além da confusão de identidade e a transição de um gênero para outro.

O apagamento destas circunstâncias denota certa marginalidade de uma história de vida. Óbvio que, como um homem cis, eu não teria como sentir, pensar, refletir como alguém trans. Porém, afetado pela experiência de Eduardo e por sua narrativa, sigo na perspectiva de pensar uma psicologia que se atente a demandas que também são histórias de vida vivida e con-vivida. Penso que se nos conduzimos por um apagamento para algo que antecede o próprio modo de ser-no-mundo sendo trans, não seria, propriamente, não alcançar o sentido de seu próprio modo de existir-no-mundo-com-outros. Assim, talvez, estaríamos também apagando as relações da pluralidade no espaço público, nos dizeres de Arendt (2018a).

A entrevista com Eduardo é provocativa, porque além de dialogar com concepções de masculinidades, também conversa com discussões contemporâneas de nosso cenário político sobre lutas de mulheres. O que quero dizer com isto não é que sua narrativa fortaleceria tais lutas, mas que ela pode dar possibilidades outras de pensarmos como seria possível agir

\footnotetext{
${ }^{65}$ A falta de higiene na região peniana está associada ao câncer de pênis entre os homens cis, motivos de amputações penianas no Brasil. A rede de cuidado e as campanhas de saúde do homem, a partir dessa perspectiva, pensam saúde para além da condição de doença, fazendo intersecção com a realidade vivida no próprio cotidiano, através da promoção e da prevenção de fatores de risco para a saúde como um todo. Há de sustentar, também, que este comportamento anti-higiênico é fruto de uma sociedade e cultura machista, que evidencia que cuidados com órgãos sexuais deveriam ser apenas para as mulheres cis, por terem órgãos mais internos.
} 
aproximando o que se requer como uma vida coletiva que acontece por/com corpos que não atendem à normatividade vigente.

Penso estas questões não somente por ele ter evidenciado o quanto foi difícil ter uma vivência ${ }^{66}$ feminina, mas porque os moldes sobre veracidades de homens e mulheres devem ser co-construídos e inaugurados pela própria legitimidade realizada cotidianamente. Esta questão aparece em diversos momentos em nosso encontro, mas chamo atenção principalmente para quando ele fala do estupro que sofreu: "Eu sai na rua... EU FUI ESTUPRADA, enquanto mulher! Isso, sem ser pra você, eu falei pra duas pessoas.", que faz-nos dialogar com uma estruturação de poder sobre o corpo do outro. O poder, neste caso, estaria destinado a quem teria o direito sobre a existência do outro, causando seu apagamento, dilaceramento, ofuscamento e invasão. ${ }^{67}$

Para além do estupro físico, há um estupro social: uma violação do direito de existir sendo quem se é. Demarca-se a violência. Para as singularidades trans, esta violação aparece na recusa a direitos básicos (como nome, acesso à saúde, mercado de trabalho, entre outros), ou simplesmente na presença que gera estranheza. "Por que toda hora você tem que falar [quando vai se apresentar para alguém] que é trans?", questiona Eduardo, pois “É bem mais fácil de falar se a pessoa te perguntar....", autenticando um lugar de existência e resistência que se dá em meio à vida pública, pois "é só a gente chegar no espaço! Nós temos direito de usar esses espaços, sendo trans ou não! Esse é sempre o nosso discurso: sendo trans ou não!".

Chegando a esses espaços, a própria presença, por si só, gera estranheza ao outros. Demarcada por Eduardo, a presença trans sinaliza que algo naquele corpo físico não está em conformidade com as características externas ou outras considerações necessárias para identificar-se e/ou ser identificado como o que seria um homem ou uma mulher. Destarte, esta presença demarcada, estranha, mutante, sinaliza que seu corpo é palco manifesto da própria atestação de uma amorfia.

A forma que o corpo biológico toma - ou deveria tomar - persegue a genética, os cromossomos, a vida celular. Mas também vai de encontro às normas sociais do que se compreende por gênero ou por identidade. Isso torna-se evidente quando Eduardo fala que os traços de mulheres transexuais são comumente "repreendidos" pelo encontro grosseiro - ou

\footnotetext{
${ }^{66}$ Utilizo o termo vivência tanto por ter sido utilizado por Eduardo, como por achar que vivência e experiência se diferem quanto à implicabilidade do modo de existir. Assim, compreendo que a vivência poderia ser tomada como um espaço de "pouca reflexão", que não dialogaria, nesse caso, com seu corpo, gênero, sexualidade, desejo e comportamento, tal como frisei anteriormente amparado pelo olhar de Benjamin (2012).

${ }^{67}$ Falarei sobre o poder em capítulos posteriores, principalmente amparado pelo olhar de Hannah Arendt.
} 
"bruto", encontrado na fala "A mulher transexual não fala que é mulher transexual, porque os traços são bem mais brutos do que os nossos.".

Passo a compreender que sua narrativa caminha no sentido de apontar que com um corpo cromossômico masculino, há toda uma estruturação corpórea que demonstraria os atravessamentos do sexo biológico na própria existência feminina; enquanto o corpo cromossômico feminino, mesmo que preponderante por traços menos "grosseiros" ou "brutos", não marcaria tão fortemente uma conjuntura trans, tal qual ele expressa sobre a experiência de corporalidades trans masculinas.

Decerto, os traços da anatomia masculina são mais destacados pela estrutura óssea corporal (especialmente ombros e face) e pela falta de musculatura evidente (nas pernas e quadris, por exemplo), o que evidenciaria a transitoriedade de um corpo que vai de encontro ao padrão anátomo-cromossômico, ou melhor, a um corpo socialmente aceito como de homem. De fato, para a existência de homens e mulheres, empreendidas pela lógica do binarismo, o corpo biológico também é um marcador social (Bento, 2017a; Pelúcio, 2009), mesmo que ele não possa representar socialmente seu modo de habitar-no-mundo.

A partir dessa presença, encontro, na narrativa de Eduardo, um chamamento para pensarmos as dimensões do corpo anatômico para além de funções celulares que preponderam sobre outras. O corpo-matéria pode se apresentar como marcador da transitoriedade, além de revelar, ao mesmo tempo, certo descompasso pela própria estranheza que o demarca como sendo masculino ou feminino.

Tal presença de afirmações corpóreas descompassadas, apontam para a necessidade de pensarmos o corpo para além de um amontoado físico carnal, pois outras dimensões da vida humana podem revelar estes mesmos descompassos, demarcando fortemente atestações do que seria comum e incomum apenas a partir de um corpo. É o que aponta Eduardo ao dizer "Está na minha voz!", como se a tonalidade nela presente devesse pertencer a um determinado sexo biológico e a um determinado modelo de homem ou mulher, no qual ele não se encaixaria. Por esse caminho, poderíamos pensar a voz como mais um indício de uma consonância ou dissonância revelada pelo alinhamento de sexo biológico, gênero, orientação sexual e corpo.

Sigo pela narrativa de Eduardo, que traz:

Eu falei com a psiquiatra sobre disforia. Pelo que falei com ela, é quando a gente se sente desconfortável com algo em nós e a gente sente... não é um QUERER, é uma NECESSIDADE da mudança. Eu tenho essa disforia com os intrusos. 
Perseguindo pela noção de dissonância, a narrativa de Eduardo aponta para a necessidade de pensarmos o termo disforia. De prefixo latim dis (afastamento, negação, contrário) e vocábulo phoros, do verbo pherein (suportar), que significaria "sensação de malestar, desconforto, depressão constante”. Em sua fala, utiliza este vocábulo cinco vezes (todas no mesmo momento), associando-o sempre à recusa dos intrusos (no seu caso, das mamas e da voz).

O termo disforia dá lugar ao termo transtorno no $\mathrm{DSM} \mathrm{V}^{68}$ e foi, inclusive, adotado por alguns dicionários ${ }^{69}$, indicando abertamente $\mathrm{o}$ apontamento para a transexualidade: "Inadequação da pessoa com relação ao seu sexo, podendo acarretar depressão profunda e outros transtornos de ordem psicossocial; inclui o transexualismo, o travestismo e situações de hermafroditismo e de intersexo" (Michaellis, 2018, online).

Reparemos que, mesmo que o dicionário aponte para a "nova" nomenclatura, ainda traz em seu bojo termos como "transexualismo", "travestismo" e "hermafroditismo", atentando-se para a terminologia médica que compreende o sufixo -ismo como uma atestação de categoria nosológica. Não somente o dicionário faz certa conturbação em torno dos vocábulos utilizados para explicar o termo, como também relaciona a disforia em relação ao "sexo"70 como sine qua non para existir tais atestações de "ordem psicossocial".

Entendo o movimento de Eduardo em relacionar sua atestação de gênero como uma disforia, principalmente se, até o momento, representa a única maneira de se conseguir uma remoção cirúrgica de intrusos no corpo, tal como aponta Bento (2017a). No entanto, como discutiremos adiante, utilizar a terminologia "disforia" seria, pois, evidenciar patologicamente uma existência, firmando-a em torno de uma categoria e olvidando outras circunstâncias do viver cotidiano com este corpo.

Porém, sua fala "Esse corpo não é dessa massa, esse corpo é MEU! Acho que é por isso que os homens [trans] chamam de intrusos, porque eles são intrusos no nosso corpo. Diferente dos seios da mulher. Elas [as mulheres] fazem parte daquilo e aquilo faz parte delas." sinaliza a representação que esta "massa", não comunga ou dialoga com este corpo vivido. Evidencio o que já falei anteriormente sobre o conjunto envoltório que forma anatomicamente esta "massa" (que chamei anteriormente de seios), porém, a partir do sentido que Eduardo traz em sua

\footnotetext{
${ }^{68}$ Será discutido adiante, quando da necessidade de elaboração sobre o sentido da práxis psicológica em torno da elaboração de pareceres e laudos, além da subjugação de sua prática e elaboração diagnóstica tendo por base os manuais diagnósticos psiquiátricos.

${ }^{69}$ A exemplo, o Michaellis (online e físico).

${ }^{70}$ No caso, torna-se aqui ambíguo: ora direcionaria a compreendermos como gênero, se tem por base a composição da disforia relacionada à vida social, ora estaria confundindo sexo com genitália, se olharmos pelo viés anatômico que dissona com o social.
} 
narrativa, chamo atenção para a necessidade de pensarmos como estes corpos podem ser lidos, implicando com uma prática que é endereçada na saúde.

Há um lugar de desapropriação: não dá para chamarmos de parte, pois não lhe é parte alguma; não dá para chamarmos de seios, pois não representam este lugar; não dá para chamarmos de mamas, pois não servem para esta função; não dá para chamarmos de corpo, pois, mesmo que concretamente no seu corpo, é estranho a ele, dissonante. Daí, o caráter excêntrico e singular do lugar que colocamos o corpo-no-mundo: existe pela e na carne, mas a própria carne não dá conta de sua existência; apenas reafirma a resistência em torno da estruturação de um sentido que lhe é propriamente legítimo.

Diferentemente da massa corpórea que invade seu corpo, Eduardo percebe sua genitália como fazendo parte de seu corpo (diferente de muitos homens trans, como ele mesmo evidencia), "me sinto como um homem de boceta....". Em sua narrativa, ele chama-nos a refletir sobre sua possível não-binariedade, consideração esta que foi atestada por sua psiquiatra. É curioso notar como sua fala escorrega ora para um discurso da não-binariedade, ora para um discurso do conformismo com seu gênero, mesmo tendo clareza que não se sente "como mulher NEM UM POUCO!".

No entanto, indo para além da compreensão dos solos escorregadios em que o campo das generidades transita, na fala “Às vezes, pode até ser, não sei.", há o simulacro da condição clara da cisgeneridade compulsória apontada por um profissional "porque ela dizia que eu era não-binário!... Talvez só pelo fato de eu não ter problema com minha genitália.". Ou seja, define a alternância de julgamento pelo dizer do corpo do outro o que ele é e para que ele serve.

Por entre nosso encontro, é evidente a necessidade da hormonização como possibilidade de dar vez e lugar a uma condição masculina que ainda, talvez, não teria uma voz social, pública. É a partir do corpo que esta condição - inclusive a confirmação do nome - acontece, pois representa e simboliza o cerceamento de outra condição corporal que lhe foi imposta, abrindo diálogo para pensarmos o que entenderíamos por um corpo-existência "apto" a uma "mudança" (Butler, 2009).

Por esta via, penso que a necessidade de dar prioridade a políticas públicas e construir estratégias junto a este grupo singular, com suas particularidades próprias, seria possibilitar um enfoque em meio ao campo plural das transgeneridades. Estas políticas ou estratégias só podem ser endereçadas se o objetivo da prática profissional (seja ela de saúde ou de educação) tenha como destino a sua ação, legitimadas pela com-vivência pública, atestada por outros e outras, muito mais que o saber acadêmico-científico, que ofusca e marginaliza o fazer. 
A partir da entrevista com Eduardo, percebo que é necessário pensarmos nestas estratégias, porque estamos falando de vidas vivíveis. Estas vidas só acontecem com a participação também de profissionais e serviços que trabalhem na mesma direção que o apelo direcionado às condições democráticas e justas, sinalizando que só é possível fundamentar este destino se ele se atenta à universalidade, integralidade e equidade ${ }^{71}$, pois "Todo mundo tem que trabalhar de UMA ÚNICA FÓRMULA, digamos assim. Com uma única direção!’.

Esta estruturação dos serviços sai da esfera saúde-educação e também transita por entre outras instituições que lidam com o direito à vida, a exemplo, os cartórios civis e instituições de direitos, como um todo. Durante a escritura desta tese, o Supremo Tribunal Federal (STF) declarou que a população de travestis, mulheres transexuais e homens trans pode alterar suas documentações, fazendo utilização de nome civil tal qual identificado a partir de seu gênero.

Reitero o marco da declaração do STF, além da fala de Eduardo "dia um do três [de 2018]" como um indício que representa um avanço, mas que também indica o atraso relacional e a dívida social que o Estado incumbe. No entanto, como Eduardo fala, ainda há um descompasso que é revelado pelas "ações sem destino": "Aquele cartório faz, aquele cartório não sabe... Por que todo mundo que faz o mesmo trabalho não faz de uma única forma?". Fica a questão: Por que o trabalho das instituições não é linear e intercruza-se à própria política instaurada, a qual é a base para os "acordos humanos" serem realizados e destinados?

Destarte, em consideração a esta atitude política nas práticas profisssionais, evidencio o caráter ético que deve permear as noções e ações em saúde. Quando da fase de apresentação deste projeto de pesquisa à base da Plataforma Brasil, que agrega os Comitês de Ética em Pesquisa com Seres Humanos, tive a necessidade de olhar para a pesquisa não somente como uma pesquisa, mas como uma possibilidade de articulação de fazer-saber.

Penso que toda pesquisa que prioriza as ações humanas, histórias de vida e práticas profissionais, devem, por si só, ser uma reverberação ética e política. Ética, por sustentar uma morada, habitação de modos de ser; política, por atentar-se e destinar-se por entre acordos, ações conjuntas (Santos, 2016). Escrevo isto ao ser tocado pela narrativa de Eduardo e também pelo I Congresso Internacional de Saúde Trans já falado anteriormente, quando questionado sobre os serviços prestados pelo Hospital das Clínicas da Faculdade de Medicina da Universidade de São Paulo.

\footnotetext{
${ }^{71}$ Isso aparece, nas entrevistas, como um apontamento do quanto as políticas públicas em saúde caminham na direção de uma compreensão organicista do humano e não, de fato, respondendo a um sentido político disposto no SUS (que compreendo como uma dimensão humana da política). Esta compreensão será melhor esclarecida nos capítulos subsequentes.
} 
O apelo que Eduardo traz é também um grito ético e político, um grito de chamamento para não fazermos de nossos "sujeitos" de pesquisa mais um objeto a ser estruturado, mensurável, quantificável, observável e universalizável ${ }^{72}$ para, daí em diante, responder à nossa curiosidade e dimensionar intervenções que são feitas por e não com.

Em sua narrativa, a atenção para a transexualidade (no singular) tem também um caráter singular: "TUDO que eles fazem ali é uma pesquisa! Tanto que eles não atendem maior de idade agora, só de menor, porque de maiores de idade eles já sabem a vivência.". É interessante notar que ele faz uso do termo vivência para explicitar o lugar de fala de uma pessoa transexual, denotando a noção de uma não-implicação, de um "aprendizado", de um “conhecimento sobre o outro"; e não de experiência, que implicaria neste lugar de um conhecimento construído conjuntamente e para estas mesmas pessoas, como já tateado anteriormente.

“Todos aqueles corpos são objetos de pesquisa! Ai ficam dois anos deformando os seios dele porque A PESQUISA NÃO ESTÁ PRONTA! IsSo é HORRÍVEL!!!"”. Estes corpos, uma vez estabelecidos como objetos de pesquisa em torno de uma curiosidade alheia - "Nossa! Vamos descobrir?" - e não aleatória, pois traz questões de poder envolvidas no discurso, na prática e nas próprias ações - continuam permeando a linha violenta da abjeção, pois se estruturam por entre os crivos científicos e noções que abrigam perfis e dados epidemiológicos. Constrói-se, assim, mais um ofuscamento em detrimento de um saber, no qual o sujeito-objeto-abjeto tornase escombro de sua própria condição humana "subjugada".

Estes crivos, que circunscrevem a legitimidade corporal em torno de discussões científicas, permitem com que as leituras dos profissionais e endereçamentos de práticas sejam norteadas pela mesma via. Quando, de fato, penso que a transexualidade, muitas vezes, não é o cerne da questão por entre a procura nos mausoléus ${ }^{73}$ da clínica tradicional. Isso porque encontro na fala de muitas pessoas trans a importância de sua vida vivida ser digna.

No encontro com Eduardo, esta questão fica clara pela espera dos serviços e de laudos profissionais técnicos, legitimação de corpo, uso da testosterona e possíveis cirurgias "redesignadoras" que deflagram sentimentos depressivos, ansiosos e suicidas na sua trajetória. A sua chamativa para os profissionais psis encontra-se na direção de atentarmos para outros inúmeros aspectos de seu cotidiano, pois como ele fala, ele já sabe, propriamente, quem é e sabe dizer sobre e de seu corpo. Isto fica evidente pela complexidade de (im)permanência de seu próprio viver habitual, "Porque eu passei a minha vida INTEIRA e eu CANSEI de esperar pra viver.".

\footnotetext{
${ }^{72}$ Questões discutidas adiante, quando da evidência do biopoder nas práticas profissionais e de pesquisa.

73 "Mausoléu" está aqui empregado tanto no sentido de templo, como no sentido de "túmulo".
} 
Em meio ao encontro com Eduardo, vi-me tocado diversas vezes. Quantas vezes a masculinidade não é testada? Quantas vezes não esbarramos com masculinidades tóxicas? Quantas vezes não nos tornamos escravos de nosso próprio sistema, de um profissional, de uma prática? Quantas vezes, nós, psicólogos e psicólogas, atendemos nossos clientes e não dispomos a falar com, a veracizar a legitimidade de suas existências, de suas escolhas, de suas dores, de suas alegrias?

Além de um chamamento para repensarmos nossa prática psicológica e atuarmos politicamente em nossa ação clínica, terminando sua historicização, Eduardo, em sua presença, deixa-nos um apelo: "Uma coisa que é importante para a vivência trans é DESTREZA!!! É olhar FIRME....". A sustentação do olhar, da presença, do "carão" e do corpo sinaliza uma reexistência, um apontamento de permanecer pertencendo, permitindo que a massa social não tome posse de seu corpo, não se torne intrusiva sobre sua existência, sobre sua transmasculinidade, mas que "Olhem a gente como pessoas, como VIDAS! [vivíveis]!!!". 


\section{4 "CÁLICE": a ciência, os manuais e a psicologia como categorias (de)formadoras das transexualidades e travestilidades}

Seguindo pelas narrativas advindas dos encontros com Fernanda, Joyce e Eduardo, encontramos diversos entrelaçamentos para pensar as dimensões reveladas pelas suas histórias. Nesta direção, os encontros apontaram para a necessidade de a psicologia olhar para questões ainda não muito claras, questões estas que dizem respeito a estas três histórias em específico, mas que demarcam a confusão (ou confissão) dos saberes-fazeres e fazeres-saberes que a própria psicologia, enquanto disciplina, ciência e profissão, encontra.

Assim, é importante evidenciar que, nesse momento, o capítulo vai em direção às narrativas anteriormente trazidas, o que não quer dizer que o que segue contemple as diversas experiências de mulheres transexuais, homens trans e travestis. A partir do diálogo já trazido anteriormente, alguns eixos norteadores foram se abrindo enquanto questões a serem pensadas.

O que a psicologia tem a dizer sobre estes corpos? Seria a psicologia uma formadora de subjetividades? É a psicologia a responsável por ratificar discursos? Ou melhor, estaria a psicologia corroborando o discurso psicopatológico para as existências trans? Os corpos "estranhos" também indicariam existências estranhas malogradas pela ciência? Se a psicologia é produtora de saberes, é a partir dela que consideraríamos existência como verdadeira?

Tais questionamentos acompanharam-me desde o início desta tese de doutoramento e permanecem até aqui. Embora façamos ciência, é nítido que o próprio discurso científico se refaz, o que aponta para a necessidade de construirmos a ciência cotidianamente e atentarmos para as especificidades antes de reproduzirmos discursos vazios. O que pretendo aqui não é delegar direcionamentos às práticas psicológica, pedagógica, jurídica ou médica, mas apontar possibilidades reflexivas que encaminhem questões para repensarmos os modelos de ciência e de práticas vigentes.

Por entre esses relevos, percebo que os territórios por onde passei sinalizam a necessidade de não seguir mapas, mas de fazer um caminho pausado: sentando sob às sombras, descansando para tomar uma água e ouvir o canto dos pássaros ou até mesmo subir em pedras escorregadias e entrar em rios bravos.

Durante esta pesquisa, comumente encontrei-me com diversos horizontes para poder, minimamente, compreender que tudo se fazia outro para mim. Dialogar com autores desconhecidos por mim, teorias e filosofias que apontam pressupostos para além de um saber psicológico, provocam um rompimento - ou melhor, uma fissura - na minha formação. De um 
lado, encontro o que seria "minha formação psi" como a chancela geradora de um conhecimento; de outro, esbarro na necessidade de rearticular meu olhar, minha fala e minha escuta para, a partir disso, reencontrar um sentido nesta formação.

Deste modo, sinalizo que o capítulo seguirá quatro pontos. No primeiro, buscarei discutir como a ciência apodera-se do discurso ratificador sobre quem e como são o homem e a mulher "de verdade", pondo em questão as categorias travesti e transexual. Após isto, discuto o Manual Diagnóstico e Estatístico de Transtornos Mentais (DSM-5) e a Classificação Estatística Internacional de Doenças e Problemas Relacionados à Saúde (CID-11) como documentos moduladores que atestam a disforia e incongruência dos gêneros, respectivamente. No terceiro momento, dialogarei com as portarias que regulamentam o processo transexualizador do Sistema Único de Saúde (SUS), na tentativa de compreender como o dispositivo saúde compreende as corporalidades trans. No quarto e último momento deste capítulo, discutirei como a psicologia se insere em e dialoga com as delegações sobre o processo transexualizador e travestilizador no SUS.

\section{1 "Como beber dessa bebida amarga": a ciência como juíza}

Para iniciar este escrito, trago Keila Simpson (2015), atual presidenta da Associação Nacional de Travestis e Transexuais - ANTRA: "Travestis e transexuais são populações que carregam uma imensa carga de preconceitos desde a sua aparição" (p. 9). Num primeiro momento, ao lermos esta fala, podemos pensar, tal como aponta o início do próprio texto da autora, sobre o surgimento de travestis e transexuais no Brasil e no mundo. Tais populações, primariamente, estiveram associadas a eventos artísticos (tais como teatro e música). No entanto, suas aparições eram reveladas não na claridade, como o próprio termo "aparecer" dá indícios, mas subjacentes aos segredos da noite.

Tais segredos, revelados nos escombros das surdinas, conectam a aparição de travestis e transexuais à uma realidade marcada no e para o corpo: o sexo biológico. A partir de tal leitura, as identidades trans são lidas e compreendidas como fundamento último, direcionadas, claramente, à construção material e civilizatória do homem e da mulher. De um lado, a substância primária que originaria a atividade e o poder (o homem) e, de outro, a substância secundária que encontraria na receptividade o seu serviço (a mulher).

Assim, entre o homem e a mulher "de verdade", estariam todas as outras categorias que não se encaixavam na primazia biológica encarcerada no corpo masculino e feminino. Portanto, para se ter esta demarcação, seria necessário enfatizar o que atestaria a diferenciação das 
categorias homem e mulher para, a partir disso, indicar o que não seria um nem outro, mas o outro-nenhum.

"Aqui no Brasil e em boa parte do mundo, acostumou-se a lidar somente com o homem e a mulher. Sendo assim, qualquer coisa que fuja desse binarismo é olhado com preconceito e com discriminação.” (Simpson, 2015, p.10). O binarismo homem-mulher é marcado pela atestação genital binária e dualística pênis-vulva, questão centralizadora de debates (Bento, 2017a; Leite Jr., 2011). Como se sabe, a medicina envereda por esta lógica técnica e instrumental para diferenciar os humanos nestas categorias que, obviamente, direcionam a vida e os modos biológicos e sociais que são suscitados nesse desafio cromossômico. Como se diz, "a vida biológica é uma verdadeira beleza". Beleza para quem?

Segundo Leite Jr. (2011),

Até o século XVIII não havia a preocupação em focar exclusivamente a questão nos genitais de uma pessoa para saber se ela era homem ou mulher.... Possuir um pênis ou uma vagina era uma das características, mas não a privilegiada, que formava um todo Homem/masculino ou Mulher/feminino, pois mesmo esta diferenciação entre sexo e gênero ainda não fazia parte do universo conceitual do período e tanto o sexo quanto o gênero formavam uma única expressão do ser. (p.57)

Deste modo, toda a caracterização de uma figura humana seria notoriamente identificada a partir de suas composições corporais, que demarcariam seu espaço e suas condutas sociais e civilizatórias. Ao que parece, esse universo binário entra em cena no século XIX, quando da necessidade de a ciência construir a "nova" caracterização específica da normalidade e do patológico, hierarquizando as identidades "homem" e "mulher" a partir das construções científicas sobre os corpos sociais (Beluche, 2008).

Para a manutenção da vida civilizatória, homem e mulher deteriam o poder da reprodução e continuação da espécie, fato direcionado pelos cânones religiosos e reiterados diariamente em praça pública. Com tais indicações e consequentes denúncias sobre o homem e a mulher, assim como seus valores sociais e morais, o espaço urbano passa a ser o roteiro central da manutenção da família; ou seja, era necessário construir espaços categóricos para fundamentar certos direitos e deveres para a vida privada e pública.

Seguindo por esta lógica, as categorias analíticas (sexo biológico, gênero, orientação sexual e corpo) comporiam um conjunto que determinaria o que conhecemos por sexualidade, mesmo que ela não fosse privilegiada na esfera pública. Por essa categorização, entra em cena um conhecimento central que dita como deveriam ser os corpos sociais, focando em lacunas do corpo biológico. 
Assim, a figura humana passa a ser conhecida a partir da lógica causal entre as quatro categorias (sexo biológico, gênero ${ }^{74}$, orientação sexual e corpo), testemunhadas pelo modelo patriarcal, cisheteronormativo, que dita a regulação e detenção de poderes, radicalizando estruturas fortes sobre categorias frágeis. Essa estrutura punha os corpos em situação de controle de normas hegemônicas, concretizando a dominação da posição do homem (macho) sobre a mulher (fêmea).

O discurso patriarcal radicaliza e cinde o "sujeito" no humano "completo" (homem) e no humano "incompleto" (mulher), revelando que a dissidência das categorias está, fundamentalmente, marcada pela presença/ausência do falo. Caminhando por esta perspectiva, a figura da mulher centralizava-se muito mais na figura de mãe do que na da própria mulher (Beluche, 2008). Isso nos faz entender que a evidência de sua existência se firmava no ato de conceber e maternar, enquanto ao homem cabia a "árdua" tarefa de ser homem, não se tornar: a naturalização do estado de mulher, aos passos da forte centralização da ciência, enquanto lógica ditadora, era revelada em razão da sua possibilidade de reprodução, enquanto ao homem era dada a autonomia de sujeito anterior aos seus "atos" sociais.

Essa "cristalização" do ideal humano, a saber, da notória divisão da humanidade entre homens e mulheres e suas subsequentes verdadeiras expressões de continuidade da lógica dos "sexos", impõe sobre a humanidade uma impossibilidade de dizer sobre si mesma, requerendo que se diga apenas do que lhe é comum em torno desta mesma verdade. Assim, não haveria espaço para se questionar o que seria "mulher" ou "homem", pois o nascimento seria responsável pelo destino de fazer-se como homem ou como mulher.

Foucault (2017) aponta que essa distinção panóptica diz respeito aos escombros que dividem o Estado do indivíduo e seu sexo, elegendo uma disputa sobre verdades postas. Tal divisão, ao longo do século XIX, colocará o homem e a mulher "de verdade" em jogo, justamente pelo questionamento tecido em torno não só das diferenciações sexuais ou da construção binária dos corpos, mas sobretudo como uma disputa pública de poderes que elegeria tais verdades como hegemônicas.

Destarte, esses discursos entram em jogo quando há necessidade de questionar o lugar da mulher na sociedade, uma vez que ela, até então, era entendida como "o segundo sexo"75", ou seja, era entendida apenas como uma ramificação do homem (o primeiro sexo). Aqui, fica

\footnotetext{
${ }^{74}$ Obviamente, não havia esta discussão que há hoje, justamente por os corpos humanos serem alinhados à lógica apresentada e, consequentemente, lidos pelo prisma da ordem de nascimento centralizada na genitália. O gênero, assim, estaria implícito na categoria sexo.

${ }^{75}$ Daí, toda a reviravolta de Simone de Beauvoir em frisar a evidência de que não se nasce mulher, mas "torna-se mulher", justamente pelo fato de que o nascimento não implicaria na conclusão absoluta para o feminino.
} 
evidente que essa concepção dá início ao pensamento feminista ${ }^{76}$, que, resolutamente e a partir das reflexões em torno das verdades postas, preocupa-se com as hierarquizações sociais e com a sobreposição de poderes do homem sobre a mulher.

De fato, o mote central desta discussão, no Brasil, representa principalmente dois marcos históricos: o primeiro, em 1917, com a "Greve Geral", quando o coletivo de mulheres reivindicou direitos trabalhistas e reprodutivos; e o segundo, em 1932, quando as brasileiras conseguiram o direito ao voto ${ }^{77}$. Essas reviravoltas repercutem no país uma onda de rupturas que sinaliza a desigualdade, o desamparo e a desestruturação que colocam em abjeção a mulher em detrimento do homem.

Para Araújo (2016), “A alteridade mulher foi negada em sua égide, pois a sua positividade foi traída, foi recusada como essência" (p.31), uma vez que a realidade humana da mulher estaria à mercê do que era relativizado perante o homem, dado que a existência deste já estaria dada, e à mulher caberia anunciar-se enquanto "aquilo que não era" - não era $o$ homem.

Assim, a estrutura patriarcal requeria da mulher a construção de espaços para "fazer-se mulher", desconstruindo toda a (bio)lógica centrada no farto destino em amparar-se à sombra do homem. É, então, “visando 'rejeitar' um determinismo biológico... que o Gênero surgiu enquanto categoria de análise" (Araújo, 2016, p. 47).

É importante frisar que, à época de tais discussões, a psicologia ainda não era uma profissão regulamentada no Brasil; no entanto, trazia diversas dimensões, espalhadas por diversas teorias no mundo sobre o humano, que repercutiam no modo como as ciências dignificavam as existências homem e mulher. De fato, tais perspectivas estavam amparadas por modelos ainda circunscritos no que se compreendia por ciência e, claro, alinhavadas às concepções médicas fundamentadas em códigos e condutas que transitariam entre o normal e o patológico.

Assim, inscreve-se e escreve-se uma psicologia que não se atenta às especificidades humanas, mas que direciona práticas e modos de interpretação de acordo com manuais

\footnotetext{
${ }^{76}$ É importante esclarecer que, apesar de o movimento feminista trazer essas discussões à pauta, não consegue abranger todas as categorias do "ser mulher". Há uma crítica profunda na atualidade às discussões feministas, especialmente porque este movimento inicia-se com mulheres brancas e de classe média e, portanto, excluiria outras experiências de mulheres, tais como as negras e as mulheres transexuais, por exemplo. Sobre essa discussão, em específico, algumas teóricas feministas negras, no Brasil, evidenciam o quanto o movimento feminista primário não se atenta para nem compreende as interseccionalidades (as intersecções das identidades sociais relacionadas à opressão, discriminação e/ou dominação).

${ }^{77}$ É importante frisar que outros momentos tiveram também sua importância, como também, ainda hoje, temos diversas discussões e acontecimentos históricos com a participação de mulheres como mote central de ações no cotidiano brasileiro. No entanto, elegi estes dois acontecimentos apenas para relacionar com como a força do movimento feminista consegue repercussão na esfera pública, tendo em vista os direitos negados à categoria mulher.
} 
diagnósticos para e na qualificação de doenças e transtornos. Enquanto discussão de gênero, a psicologia, no Brasil, incorpora-se a partir da reivindicação dos movimentos sociais, especialmente quanto à inauguração das políticas públicas fundamentadas em torno da assistência social dos sujeitos, após a Constituição Federal de 1988.

Em trabalho anterior (Melo, 2015), sinalizo a abstenção da psicologia frente aos estudos sobre o corpo, refletindo que as direções tomadas pelos profissionais de psicologia especificamente os que lidam e atuam em hospitais - são embebecidas pelo olhar e interpretação do campo médico. Como falado anteriormente, Fernanda, Joyce e Eduardo trazem o desconforto em torno das práticas psicológicas frente a tais demandas, o que aponta a falta de clareza sobre o seu "objeto psi" de estudo: o humano.

Esta conjuntura trazida pelos narradores testemunha o olhar coercitivo de quem "está de fora", um olhar que dita normas, regras, padrões e conjuntos que apontam para o "homem verdadeiro" e a "mulher verdadeira". O discurso das verdades psicológicas dialoga com os discursos científicos, pois não haveria espaço para uma psicologia que não "fizesse" ciência a partir do já posto e levado para a pluralidade humana.

Assim, é evidente que a psicologia fazia a distinção homem-mulher a partir também da caracterização corpórea e traços achados no corpo, mesmo que não tivesse a genitália como seu objeto de estudo. Percebe-se, portanto, que a compreensão humana para a psicologia, nesse sentido, tratava-se de emaranhados de confabulações encontradas na permanência das verdades dos sexos - ou, melhor dizendo, instaurava-se a procura pelo "sexo dos anjos" -, uma discussão fundamentada nos achados científicos sobre a "verdade" pré-estabelecida e que não caberia análise: homem é homem, mulher é mulher. Mas mais uma vez a pergunta: o que é um homem e o que é uma mulher? Ou melhor, "como ser homem e como ser mulher?".

A diagramação sobre as inverdades dos homens e das mulheres enquanto tais aparece quando há necessidade de estudar a homossexualidade, até então compreendida como homossexualismo. Como sabemos, os estudos psicológicos sobre as "anomalias" sexuais datam de muito, justamente por estarem acossadas aos escrutínios médicos em torno da psicopatologia. Toda e qualquer demarcação de experiência sexual que fugisse da amarração homem para mulher e mulher para homem (heterossexualidade) significaria algo transtornado, perverso, infortúnio.

O marco fundamental destes estudos, especialmente dos que focalizavam as análises da perversão, é incorporado às teorias psicológicas a partir do nascedouro da psicanálise, em meados de 1900, com Sigmund Freud, que, logo depois, se tornaria uma das maiores forças teóricas na psicologia. "O homem do seu tempo" não parece ser a melhor das características 
dadas ao psicanalista, pois, à época, já havia discussões (especialmente na França) sobre a igualdade entre os homens e as mulheres e as diversas identidades do masculino e do feminino.

Não obstante, como médico e cientista, Freud precisaria cumprir "o papel da ciência" e enveredar-se pelos estudos que trouxessem a universalização de seus achados. Desde então, encara a academia científica austríaca para defender a sua tese sobre a histeria, centralizando a mulher como objeto de estudo e inserindo-a numa perspectiva passiva: a ausência do falo suscitaria uma "inveja" que repercutiria num material inconsciente reprimido. Nitidamente, esta teoria gerou diversas discussões e contrapontos, inclusive porque Freud coloca a sexualidade como uma categoria de análise a ser estudada a partir da infância.

Apesar desses estudos serem fortemente criticados na Europa, principalmente pelo fato de Freud incorporar a sexualidade na vida infantil e de levar para os estudos científicos uma possível junção dos conteúdos mentais para o corpo, há um importante marco da psicanálise nos estudos sobre a sexualidade, especialmente no que dirá respeito à homossexualidade, à transexualidade e à travestilidade ${ }^{78}$.

Com estas perspectivas focalizadas nas dimensões sobre as noções de homem e mulher, as sociedades modernas foram embebecidas pelo olhar curioso da distinção homem-mulher, centralizando a ordem dos discursos em suas funções sociais, propriamente ditas. Assim,

Cada sexo vê, portanto, que lhe atribuem um papel exato e expressões autorizadas da sexualidade. No entanto, as mulheres, mais que os homens, focalizam os discursos científicos em nome de sua função materna. A teoria freudiana... constitui uma considerável ruptura, visto que se passa de uma sexualidade reprodutiva a uma sexualidade hedonista. (Sohn, 2011, p.119)

Nesse sentido, o deslocamento do ato sexual como fim único reprodutivo, embasado pelo poder do homem sobre a mulher, dá lugar ao ato sexual com fins prazerosos - mesmo que, ainda, somente para o homem (no caso da experiência heterossexual). Esta passagem das discussões confinadas aos subúrbios das perversões e pulsões sexuais concretizam a reformulação da sexualidade normal, perseguindo a linha da heterossexualidade e do encontro entre os genitais (pênis e vagina).

O desencontro dessa passagem firma-se na delegação do desejo indiciado pela libido do homem, uma vez que aquela estaria firmada nele. Assim, com esta reformulação da ordem sexual, seria o pênis o centro da questão, o que rechaçaria a presença e a participação da mulher

\footnotetext{
${ }^{78}$ Utilizo as palavras no singular por elas ainda estarem acossadas a uma compreensão de homossexualismo, transexualismo e travestismo (este último amparado por uma noção de fetichismo, na qual me deterei no ponto seguinte deste capítulo).
} 
no ato sexual. O corpo da mulher seria escrutinado pela medicina como "um corpo grávido que se deve conduzir até o parto seguro e, depois, colocar ao serviço do bebê” (Sohn, 2011, p.126).

Obviamente, essa discussão sobre o corpo que gesta está num pedestal revelado pela norma estabelecida na divisão dos sexos biologicamente nascentes. Mesmo com as discussões e debates atuais sobre o corpo trans que gesta, ainda se percebe o despreparo e o descaso da instituição de saúde e da própria ciência com tais experiências.

Ao falar de saúde, percebemos, nas entrevistas de Fernanda e Joyce, principalmente, que há um processo árduo e constrangedor no que diz respeito ao chamamento do "ser mulher". É como se o dispositivo saúde existisse apenas para corrigir as fissuras e as marcas que acusam e refletem o sexo biológico oposto no corpo em questão, uma maneira de apagar as marcas e de higienizá-lo pelo reparo, tornando-o complacente e endividado consigo mesmo.

Mesmo que essas amarras concebidas pela ciência enfatizem e denunciem a desesperada atitude de higienizar os corpos, a medicina não consegue dar conta da notória subdivisão da mulher em relação ao homem. Como vimos anteriormente na entrevista com Fernanda, parece que a saúde pouco se atenta a investigar noções biológicas dos corpos dos homens, denunciadas também por Eduardo, ao falar que os médicos pouco se preocupam em relação à readequação corporal à identidade de gênero de homens trans.

Sohn (2011) sinaliza que os processos dos estudos médicos em torno dos corpos sexuados e divididos entre homem e mulher são amparados não somente pela questão reprodutiva, como também pela negligência dos conhecimentos sobre o próprio corpo masculino. A autora aponta que, no começo do século XX, os estudos tinham como marco essas individuações biológicas que eram fortemente percebidas, uma vez que o sistema hormonal do homem era completamente deixado de lado, originando em situações reprodutivas diferente para homens e mulheres (como, por exemplo, a contracepção, que, até hoje, é alvo de estudos químicos relacionados às mulheres, assim como os estudos da esterilidade entre meados dos $\operatorname{anos} 1960 / 1970)$.

É interessante que os estudos que suscitaram o escrutínio do corpo do homem eram voltados exclusivamente para as funções sexuais ativas, ou seja, para os problemas relacionados à impotência sexual. Mais uma vez, fica evidente que a preocupação científica em volta do corpo do homem funda-se numa concepção falocêntrica, machista e heteronormativa, que sintetiza a existência do homem à atividade peniana. Inicia-se, assim, em 1997, a comercialização em grande escala do Viagra, como uma maneira de reparar e prolongar o estado de "macho" do homem. 
Muito embora a teoria freudiana já diga que há uma importância em pensar as questões de saúde do corpo amparadas também por materiais reprimidos e recalcados do inconsciente, o que se entende hoje por saúde mental começa a ser explanado com o intuito de reparo do corpo para alterar estruturas psicológicas, tidas como estruturas mentais - como o que se percebe em torno do corpo trans.

Evidentemente, os estudos que naturalizavam esse corpo radicalizavam-no e encobriamno, na tentativa de apontar a distinção entre o corpo do homem e o corpo da mulher. Conforme Sohn (2011) aponta, "os psiquiatras devem também levar em conta os progressos da biologia que, com a descoberta dos cromossomos e dos hormônios sexuais, permitem compreender melhor as funções da sexuação e das disfunções" (p. 129). Nessa direção, amplamente focalizados ainda na ideia de reparo dos corpos sexuados, iniciam-se os estudos sobre as primeiras modificações corporais, com as cirurgias de "mudança de sexo" para pessoas que sentiam profundo incômodo com a ordem genital em questão.

No entanto, esses estudos ainda eram pouco disseminados, permanecendo em questão a ordem discursiva dos genitais e prazeres da carne. Com o surgimento da Aids, no século XX, a ciência inicia um forte descortinamento. A sexualidade passa, assim, a ser mais uma vez vigiada e punida (Foucault, 2017).

Ainda hoje, diversos são os estudos e pesquisas no que diz respeito ao vírus HIV ou à Aids, no Brasil e no mundo. No entanto, mesmo que com diversas discussões em saúde pública e com diversas formas de meios de comunicação e serviços, há uma constante luta na tentativa de firmar estratégias que reflitam o cuidado e a promoção de saúde em torno da população.

Como se sabe, existem vários estudos no Brasil que sinalizam a importância de lidar com a promoção de saúde para populações vulneráveis, tais como: homens e mulheres profissionais do sexo, população ribeirinha, população quilombola, caminhoneiros e travestis e mulheres transexuais trabalhadoras do sexo. Nessa direção, os estudos em ciências humanas e sociais recentes apontam para a fragilidade na forma como a saúde lida com essas questões envolvendo gênero e sexualidade (Bento, 2017a; Pelúcio, 2009). Sinalizam, ainda, que por mais que saibamos que qualquer pessoa pode ser infectada pelo vírus HIV, ele ainda é focado nestes grupos vulneráveis, antes denominado amplamente de "grupos de risco".

Assim, vê-se que os estudos citados pelas autoras, em sua maioria, focam nas travestis e nas mulheres transexuais, por exemplo, por estas afetarem diretamente os "bons costumes" da família tradicional brasileira. Obviamente, a forma de reparo que encontramos atualmente no dispositivo saúde, em relação a travestis e mulheres transexuais, não dá conta, pois foca em pontes que se deslocam, quando deveria também focalizar nos "vetores" (homens cis que são 
clientes sexuais). Há de nos questionarmos se o modo como a saúde lida com essa população em específico não priorizaria, ainda, o discurso heterossexista e machista no endereçamento de práticas que nem mesmo fazem sentido à população a que se destina.

Assim, os estudos de gênero que focalizam as distinções, semelhanças e confluências entre homens e mulheres também abrem direcionamentos para pensarmos que, para além do binômio decorrente da biologia, outras experiências precisam ser cuidadas. A cisgeneridade não é o único modelo de corpo, de saúde, de vigilância e de poder. É preciso cuidarmos das singularidades que saem da esfera cis: as existências trans.

4.2 "Tragar a dor, engolir a labuta": o DSM-5 e a CID-11 como produtores de formas e fôrmas para os gêneros

Neste ponto, partirei das noções iniciais que a ciência confabulou em torno dos corpos trans, a partir de sua anormalidade e incongruência, para, então, enveredar pela noção de despatologização dos gêneros e experiências sexuais. Diante disso, como sabemos, dois são os principais documentos científicos que servem como modelo para a prática em saúde médica, bem como para a normatização, categorização e patologização: 1) o Manual Diagnóstico e Estatístico de Transtornos Mentais (DSM), atualmente na $5^{\text {a }}$ edição, lançado pela American Psychiatric Association (2014), e 2) a Classificação Estatística Internacional de Doenças e Problemas Relacionados à Saúde (CID), em sua $11^{\mathrm{a}}$ revisão, produzido pela Organização Mundial de Saúde (OMS), em 2018.

Segundo Bento (2017a), há um constante debate em torno da despatologização dos gêneros. Tal debate entra em questão principalmente nos Estados Unidos com grupos minoritários, na tentativa de retirar as identidades trans destes documentos, uma vez que essa inserção é o que ainda fundamenta as práticas médicas em torno das compreensões que resultam na marginalização, no domínio e no poder sobre os corpos trans.

Ao retratar a perspectiva patológica sobre tais condições de gênero, o DSM-5 aponta para veracidade, padrões, sintomatologias e perfis comportamentais que definem e subdividem "transtornos" em categorias nosológicas. Assim, primeiramente, esse documento busca fazer uma distinção, ainda na introdução, sobre o que denomina de "diferenças sexuais" e "diferenças de gênero", para que se consiga delinear como cada transtorno poderá apresentar-se de variadas maneiras a depender do sexo biológico ou do gênero expresso:

Diferenças sexuais e de gênero, da forma como se relacionam às causas e à expressão de condições médicas, estão estabelecidas para uma série de doenças, incluindo determinados 
transtornos mentais. Críticas ao DSM-5 incluem a análise de possíveis diferenças entre homens e mulheres na expressão de doença mental. Em termos de nomenclatura, diferenças sexuais são variações atribuídas aos órgãos reprodutores de um indivíduo e ao complemento cromossômico $\mathrm{XX}$ ou XY. Diferenças de gênero são variações que resultam tanto do sexo biológico como da autorrepresentação do indivíduo, que inclui consequências psicológicas, comportamentais e sociais do gênero percebido. O termo diferenças de gênero é utilizado no DSM-5 porque, com mais frequência, as diferenças entre homens e mulheres são o resultado tanto do sexo biológico quanto da autorrepresentação individual. Contudo, algumas diferenças baseiam-se apenas no sexo biológico. (APA, 2014, p.15, versão online).

Perseguindo a lógica relacionada ao DSM-5, encontramos a mesma perspectiva anteriormente mencionada, na qual utiliza-se do termo "sexual" como algo que denota e aponta única e exclusivamente para a esfera biológica, requerendo a necessidade da diferenciação cromossômica para a explicação do que seria mulher ou homem. É importante, mesmo que ainda resguardado no impulso científico em manter a veracização dos gêneros, que este documento incorpore a "autorrepresentação do indivíduo" na identificação das diferenças de gênero, fato que até a quarta edição ainda não era evidente. No entanto, essas considerações são camufladas, quando há a necessidade de observação e de vigilância das expressões "corretas" para cada gênero em questão - principalmente quando da necessidade de classificação patológica da transexualidade.

O manual em questão denomina "Disforia de Gênero" o desacordo entre a expressão e/ou identidade de gênero ao sexo biológico, tal como vimos como termo fortemente utilizado na entrevista com Eduardo. Comumente, esse termo foi empregado na tentativa de apontar o desalinho existente entre a anatomia biológica de um corpo e a identidade desse corpo, resultando, segundo o manual, em "forte sofrimento", o que se enquadraria, psicológica e psiquiatricamente, num transtorno psicológico ou numa doença mental.

O manual deixa claro que o termo gênero foi utilizado no documento a partir da dissonância resultante de algumas pessoas intersexo, que possuíam "genitália ambígua" e foram designadas a um sexo biológico masculino ou feminino e, ao tornarem-se adultas, desempenharam uma identificação não uniforme com o sexo que lhes foi designado. Assim, percebemos que, para os ditames médicos, por mais que compreendamos que gênero é uma categoria cultural/social de análise, que desempenha uma compreensão focada na experiência dos sujeitos, ele acaba por ser demarcado por um desacordo em prol da biologia resultante do nascimento que não é acompanhada ao longo da vida.

Deste modo, o DSM-5 (APA, 2014) aponta que "Disforia de gênero refere-se ao sofrimento que pode acompanhar a incongruência entre o gênero experimentado ou expresso e o gênero designado de uma pessoa.” (p.451), evidenciando que há um sofrimento em torno de 
uma experiência clínica, pois " $\mathrm{O}$ termo atual é mais descritivo do que o termo anterior transtorno de identidade de gênero, do DSM-IV, e foca a disforia como um problema clínico, e não como identidade por si própria.” (p. 452).

Há de nos questionarmos o que realmente o DSM-5 quer dizer quando foca a disforia como um sofrimento. Ao que parece, seria a disforia o que acusaria a atestação de "viver com um gênero não designado" e que, portanto, resultaria na indicação de possíveis mudanças no corpo ou no tratamento especializado para a demanda em questão. Como deixa claro, o termo foca na problemática clínica, não na identidade expressa, indicando minimamente que a transexualidade só seria verdadeira quando expressa via sofrimento, a partir do desacordo com o gênero designado junto ao sexo, no nascimento.

O capítulo intitulado Disforia de Gênero inicia com a categorização da "problemática" na infância, na qual não me deterei neste momento, ainda que seja importante para pensarmos as novas maneiras corretivas de direcionamento de tratamento para crianças e/ou camuflagem da categoria como "problema social". Como aponta Bento (2017a), essa questão aparece como preocupação no campo das ciências humanas e sociais, pois indica sorrateiramente que a questão das sexualidades dissidentes sempre será um problema para a saúde e se descortina como galhos que saem, indiretamente, da questão da homossexualidade - ou seja, homossexualismo - como doença.

Trago, então, a subdivisão que o manual denomina por Disforia de Gênero em Adolescentes e Adultos 302.85 (F64.1):

A. Incongruência acentuada entre o gênero experimentado/expresso e o gênero designado de uma pessoa, com duração de pelo menos seis meses, manifestada por no mínimo dois dos seguintes:

1. Incongruência acentuada entre o gênero experimentado/expresso e as características sexuais primárias e/ou secundárias (ou, em adolescentes jovens, as características sexuais secundárias previstas).

2. Forte desejo de livrar-se das próprias características sexuais primárias e/ou secundárias em razão de incongruência acentuada com o gênero experimentado/expresso (ou, em adolescentes jovens, desejo de impedir o desenvolvimento das características sexuais secundárias previstas). 3. Forte desejo pelas características sexuais primárias e/ou secundárias do outro gênero.

4. Forte desejo de pertencer ao outro gênero (ou a algum gênero alternativo diferente do designado).

5. Forte desejo de ser tratado como o outro gênero (ou como algum gênero alternativo diferente do designado).

6. Forte convicção de ter os sentimentos e reações típicos do outro gênero (ou de algum gênero alternativo diferente do designado).

B. A condição está associada a sofrimento clinicamente significativo ou prejuízo no funcionamento social, profissional ou em outras áreas importantes da vida do indivíduo. (APA, 2014, pp.452-453, versão online). 
Chamo a atenção para a primazia da necessidade do DSM em qualificar as experiências a partir de uma sintomatologia expressa em temos cronológicos lineares. Obviamente, como os manuais de saúde centram-se na ênfase diagnóstica produzida e escrita por médicos, a partir de critérios científicos sobre e de saúde/doença incrementados na prática médica, não seria diferente com o DSM.

Entretanto, a expressa ênfase da duração das características decorrentes já sinaliza o cerne do problema em questão. No ponto "A", o manual se inicia com uma série de "sintomatologia" básica requerida para que seja feito o diagnóstico. Importante aqui ressaltar que, por mais que já saibamos que nem toda pessoa trans traz em sua experiência um sofrimento (seja ele constante ou não) com a genitália, o documento evidencia a incongruência do modo como a pessoa se percebe frente à relação estabelecida com a não-identificação do órgão genital designado no nascimento, pois "Essa discrepância é o componente central do diagnóstico. Deve haver também evidências de sofrimento causado por essa incongruência." (APA, 2014, p.453, versão online).

O estabelecimento destes critérios para a confirmação da disforia é, por si só, disfórico. Segundo Bento (2017a), "Os discursos universalistas têm em comum a produção de um outro pelo esvaziamento das singularidades.... ao identificar o disfórico gênero, o DSM está usando como parâmetros de medição aquilo que é considerado socialmente aceitável” (p.43) e, assim, reverbera em práticas higienistas que resultam em negligência de existências.

Aqui, peço licença para uma citação longa do DSM-5, pois a julgo importante para pensarmos a (des)qualificação dos gêneros em prol das condutas científicas, resultando na massificação de corpos, identidades e histórias de vida:

A disforia de gênero manifesta-se de formas diferentes em grupos etários distintos. Meninas pré-puberais com disforia de gênero podem expressar o desejo de serem meninos, afirmar que são meninos ou declarar que serão homens quando crescerem. Preferem usar roupas e cortes de cabelo de meninos, com frequência são percebidas como meninos por estranhos e podem pedir para serem chamadas por um nome de menino. Essas meninas podem demonstrar identificação transgênero acentuada em brincadeiras, sonhos e fantasias.... Com frequência, sua preferência é por esportes de contato, brincadeiras agressivas e competitivas, jogos tradicionalmente masculinos e ter meninos como pares. Elas demonstram pouco interesse por brinquedos (p. ex., bonecas) ou atividades (p. ex., usar vestidos ou desempenhar papéis femininos em brincadeiras) tipicamente femininos. Às vezes, recusam-se a urinar na posição sentada.... Também podem afirmar que não querem desenvolver seios ou menstruar.

Meninos pré-puberais com disforia de gênero podem expressar o desejo ou afirmar que são meninas ou que serão meninas quando crescerem. Preferem usar trajes de meninas ou de mulheres ou podem improvisar roupas com qualquer material disponível (p. ex., usar toalhas, aventais e xales como cabelos longos ou como saias). Essas crianças podem desempenhar papéis femininos em brincadeiras (p. ex., brincar de "mãe") e com frequência se interessam intensamente por bonecas. Na maioria das vezes, preferem atividades, jogos estereotípicos e 
passatempos tradicionalmente femininos (p. ex., "brincar de casinha", desenhar quadros femininos, assistir a programas de televisão ou vídeos com personagens femininos favoritos). Bonecas estereotípicas femininas (p. ex., Barbie) geralmente são os brinquedos favoritos, e as meninas são as companheiras de brincadeira preferidas. Eles evitam brincadeiras agressivas e os esportes competitivos e demonstram pouco interesse por brinquedos estereotipicamente masculinos (p. ex., carrinhos, caminhões). Alguns fingem que não têm pênis e insistem em urinar sentados (APA, 2014).

Julgo importante tematizar essa citação por esbarrar em concepções construídas a partir de estereótipos das vivências masculinas e femininas. Se pararmos para pensar, tanto na experiência familiar (ou até mesmo nossa), quanto na experiência profissional, lidamos com estes critérios estereotipados quase todo o tempo. A tradição cultural que temos, especialmente nas culturas americanas, é de reverberar situações e comportamentos adequados e adequadas a cada gênero, como se sua naturalização acontecesse a partir da diagramação do que foi criado e instituído para cada "gênero".

Essa divisão de categorias como "masculino" e "feminino", delimitada a partir da natureza da ordem de nascimento, está também enraizada no discurso da heteronorma, embasado pelos ditames do patriarcado e da visão machista. Dessa forma a confirmação da veracidade da disforia, situada nos passos da permanência de expressão em brincadeiras, adereços, roupas e comportamentos tipificados como do gênero oposto, dialogava com a noção de homossexualismo, quando ainda era categoria nosológica no DSM-3. Somente no DSM-4, após a revisão do CID em 1990, é que a homossexualidade passa a ser considerada uma orientação sexual, não mais doença.

Aqui, é importante pensarmos se a "nova" noção de disforia de gênero, atrelada a comportamentos divergentes do que é esperado para o menino ou para a menina, não substituiria, em camuflagem, os mesmos critérios (ou parte deles) da categoria homossexualismo.

O que pretendo dizer com isso é que, talvez, apesar das discussões e do ganho de direitos do movimento de gays e lésbicas em relação à despatologização da orientação sexual, em detrimento dos "comportamentos moduladores de homem e mulher", precisamos estar atentos às formas não oficiais, porém oficiosas, de dar nome diferente a uma questão similar. Assim, higienizar corpos a partir de experiências decorrentes de comportamentos desnaturais para o discurso científico. "Ou seja, a armadilha [do diagnóstico] é simples" (Bento, 2017a, p.154, colchetes meus).

Segundo a autora supracitada, essa discussão apoia-se numa perspectiva que dialoga com uma noção violenta no que tange às compreensões das sexualidades, na qual o gênero 
passa a ser o registro introdutório para se praticar a homofobia e a transfobia institucionalizada. Esta caracterização do DSM é apoiada pela Classificação Internacional de Doenças, que normatiza e delimita, por meio de códigos, a tipificação de cada anormalidade da vida humana.

Em junho de 2018, aconteceu um marco histórico acerca do tema trans: a retirada desta categoria na inscrição dos transtornos mentais da CID. A transexualidade, assim como a travestilidade, passam a ser compreendidas como incongruência de gênero. De fato, essa compreensão, que se aproxima de uma noção de "não conformidade", "não congruência", retira as "características" sublocadas como transtorno para uma reflexão que coloca a experiência de identidade da pessoa como foco. Ainda que a CID faça esta distinção, não podemos esquecer que a transexualidade e a travestilidade (transexualismo e travestismo) ainda estão num documento chamado de Classificação Internacional de Doenças.

Assim, trago a categorização da CID para a discussão. Como já referido, estamos na $11^{\mathrm{a}}$ edição do documento. No entanto, com as mudanças presentes, iniciarei pela $10^{\mathrm{a}}$ edição da CID, quando ainda a incongruência de gênero tratava-se de uma subcategoria dos Transtornos Mentais (categoria F).

Na CID-10, encontramos a categorização "F64 Transtornos da identidade sexual" na adolescência ou vida adulta, com os seguintes apontamentos:

F64.0 Transexualismo: Trata-se de um desejo de viver e ser aceito enquanto pessoa do sexo oposto. Este desejo se acompanha em geral de um sentimento de mal estar ou de inadaptação por referência a seu próprio sexo anatômico e do desejo de submeter-se a uma intervenção cirúrgica ou a um tratamento hormonal a fim de tornar seu corpo tão conforme quanto possível ao sexo desejado.

F64.1 Travestismo bivalente: Este termo designa o fato de usar vestimentas do sexo oposto durante uma parte de sua existência, de modo a satisfazer a experiência temporária de pertencer ao sexo oposto, mas sem desejo de alteração sexual mais permanente ou de uma transformação cirúrgica; a mudança de vestimenta não se acompanha de excitação sexual. Transtorno de identidade sexual no adulto ou adolescente, tipo não-transexual. Exclui: travestismo fetichista (F65.1). (DATASUS, 2008, versão online).

Caminhando por uma análise compreensiva em torno da CID-10, encontramos, mais uma vez, a confusão de sexo e gênero, como se as duas categorias fossem sinônimas uma da outra. Ainda, seguindo adiante, a referência em encontrar no corpo a necessidade de reparo em busca de um "sexo verdadeiro", que definiria o sentimento em tornar-se homem ou mulher, aponta para a lacuna científica ao encarar a existência da transexualidade como algo fincado numa conduta sexual e num sofrimento advindo de um órgão genital.

Há, sem dúvida, uma massificação das existências trans, pois a CID não compreende as diversas possibilidades do campo da transexualidade, indicando apenas que o "desejo de mal- 
estar", que sucede em decorrência das amarras cromossômicas, está interligado à uma inadaptabilidade ao órgão genital e ao corpo.

Conforme Bento (2017a) aponta, existem discursos, especialmente o da psicanálise e o da endocrinologia, que apontam para a necessidade de reparo do corpo. Tais discursos buscam “dizer que uma pessoa transexual é aquela que odeia sua genitália e demanda desesperadamente uma cirurgia de transgenitalização como condição para desempenhar com sucesso a sua heterossexualidade" (p. 108).

Esses discursos entram em jogo na tentativa de delinear a linha tênue que ligaria a sexualidade às vivências sexuais e que, doravante, aponta que a transexualidade seguiria a premissa de se viver "como o sexo oposto", realizando uma conformidade. Será que esta conformidade do corpo, apontada pela CID, também não diz propriamente da necessidade de enquadramento da veracização do gênero a partir das condutas e desejos sexuais?

O que pretendo dizer com isso é que, para efetivar-se como um "F64", ou seja, alguém transexual, seria preciso, além de requerer tais intervenções no corpo, ter que perseguir a lógica estrutural de desejo e de gênero, isto é, de desejar pessoas deste "sexo" inventado. Os escrutínios do corpo pela medicina e pelas ciências da saúde, no geral, endividam as pessoas trans, pois defendem discursos que servem para guiar trajetórias em detrimento de experiências plurais.

Para Bento (2017a, 2017b), há, portanto, uma cirurgia discursiva, pois é como se todos nós, ao nascermos, fôssemos pré-cirurgiados, carregando um corpo generificado a partir de um conjunto de expectativas voltadas a ele. Sendo assim, o gênero, para a ciência, estaria sobrecarregado de precarização, visto que seria mantido como uma exigência para conceber-se como homem ou como mulher e, logo, como trans verdadeiro(a) ou não.

Conforme a autora sinaliza:

o dispositivo transexual... passou a ser lido como uma poderosa engrenagem que objetiva dar suporte à concepção segundo a qual nossas identidades sexuais e de gênero seriam um reflexo de estruturas naturais (hormônios, cromossomos, neurais). A patologização das experiências ou expressões de gênero fora da norma começou a se configurar como um mecanismo que assegura a própria existência da naturalização das identidades. (Bento, 2017a, pp.244-245).

Essa concepção, advinda das ciências naturais, materializa a sujeição no corpo. Como vimos, a CID-10 aponta para a diferenciação que precisa ser feita quanto às categorizações transexualismo e travestismo. Como disposto, diz-se que, no caso de travestis, o marco central funda-se e finda-se na caracterização prazerosa da experiência temporal de vestir-se como o “sexo" oposto, perpassando um não desejo da alteração cirúrgica no corpo (órgão genital). $\mathrm{Na}$ 
entrevista com Joyce, percebemos que essa conceituação sistêmica é falha, pois não leva em conta as peculiaridades das diferentes experiências de ser travesti.

A identidade travesti não está marcada pelo desejo temporal de caracterizar-se com vestimentas, mas sim em torno de uma generidade, que é composta por diversas circunstâncias que abrem para pensarmos o binômio feminino-masculino. $\mathrm{O}$ desejo ou não de realizar cirurgias com o intuito de redesignar o corpo não é a característica central da identidade e/ou expressões de gênero. A centralização desse debate encontra-se amplamente fundamentado nos movimentos sociais LGBTI, especialmente no que tange ao direito ao acesso à saúde integral das travestis no processo transexualizador - que será melhor explanado no subitem seguinte.

O termo travestismo, no entanto, advém da vertente psicanalítica que compreende os estudos sobre os fetiches e parafilias, indicando uma possível alteração da libido frente a objetos, roupas e modos femininos, num corpo biologicamente masculino. A CID-10 (DATASUS, 2008, versão online) enquadra o travestismo como a parafilia identificada por "Vestir roupas do sexo oposto, principalmente com o objetivo de obter excitação sexual e de criar a aparência de pessoa do sexo oposto.", subdividindo-se em "travestismo bivalente" e "travestismo fetichista".

De acordo com a CID, travesti bivalente diferencia-se de transexual por não haver um "desejo de alteração sexual mais permanente ou de uma transformação cirúrgica", enquanto a diferença entre travesti fetichista encontra-se na não excitação sexual acompanhada da vestimenta do "sexo oposto". Essas diferenciações fazem parte da ampla concepção científica sobre os discursos produzidos em torno do gênero e do corpo, refletindo, inclusive, no cotidiano de muitas pessoas trans.

Tais discursos permanecem na audácia de nomear o que seria masculino ou feminino, indicando que há uma caracterização específica e um desejo permanente de alterar desígnios do corpo para uma identidade de gênero que não condiz com o sexo biológico. Pelúcio (2009) chama-nos a atenção para pensarmos sobre tais discursos produzidos, pois entra em jogo as concepções de homem e mulher, masculino e feminino, macho e fêmea, que indicariam "verdadeiras" formas de vivenciar tais identidades.

Para a autora, "No caso das travestis, falar sobre as transformações no corpo é referirse também à materialização de um gênero, a partir da reiteração de normas que prescrevem o que é ser feminina" (pp.50-51) e que reverberam, para a mesma população, o uso de recursos discursivos que prescrevem e inscrevem no corpo a mesma concepção. As experiências travestis, assim como encontramos na entrevista com Joyce, perpassam a subversão da licença tida como natural para os corpos, desestabilizando as ordens binárias dos gêneros. 
É a partir dos mesmos ordenamentos que subvertem a lógica natural dos corpos e que saem das concepções psicopatológicas em questão que o movimento social organizado de travestis reivindica a composição do termo travestilidade, favorecendo a abertura de apropriação das diversas experiências de ser travesti, em oposição ao recurso arcaico e pejorativo que o termo travestismo abarca.

É com essas e outras reivindicações da comunidade trans, em geral, que as novas considerações da CID são avalizadas. Deste modo, na CID-11, os segmentos transexual e travesti saem da categorização psicopatológica, que se evidencia enquanto transtorno mental, para uma dimensão que dá, minimamente, espaço para pensar as questões de gênero. Mesmo que ainda não seja a forma mais "saudável" de lidar com tais aspectos, a CID-11 assume que não se trata de uma "anormalidade" do status mental, mas de uma "condição" que depende de variáveis, denominando esta condição de incongruência de gênero.

Bento (2017a), ao analisar essas categorias na CID-10 e no DSM-4, dialoga com uma leitura compreensiva com as identidades e sugere que a forma como os manuais diagnósticos lidam com essa questão "não serve para entender as fissuras, as diferenças, as exclusões sobrepostas de sujeitos que sempre ficaram fora do projeto de nação. Construir conceitos referenciados na binaridade e universalidade, produz uma violência epistemológica sutil, porque contribui para reproduzir invisibilidades" (p.48).

Fernanda, Joyce e Eduardo frisam bem essa necessidade de as pessoas, em geral, e de os profissionais da saúde lidarem com as experiências trans por meio da lógica causal que relaciona o gênero ao corpo biológico. A família e os colegas da escola de Fernanda, a equipe de médicos e enfermeiros de Joyce, a mãe e os colegas de faculdade de Eduardo são exemplos das condições de violência que o corpo trans sofre por, supostamente, não merecer a autenticação de verdadeiro.

Lembro que, quando ainda fazia parte de uma equipe num dos Centros de Cidadania LGBTI de São Paulo, ao realizar pareceres para retificação de prenome de pessoas trans, sempre perguntava sobre formas de violência veladas ou reveladas em suas trajetórias. Sempre, em cem por cento das vezes, apontavam as equipes de saúde e escolar como sendo as principais causadoras de discursos e de práticas que massificavam suas vivências dentro de padrões binários para que elas fossem legitimadas como pessoas.

Não obstante, a categorização imposta pelo sistema saúde, que prioriza e compra os discursos científicos para construir avais que direcionam estratégias, práticas e condutas, escrutinam os corpos para construir achados. A partir de tais achados, também constroem 
corpos. Nesse sentido, percebemos que tanto as noções de corpo como as concepções de saúde para esse corpo entram na disputa que envereda por entre o normal e o patológico.

Para isso, seguiremos na tentativa de compreender como a instituição de saúde percebe esses corpos, constrói direções, categoriza escolhas e direciona práticas. No Brasil, com a concretização do direito ao SUS e com a implementação de portarias que visam delimitar estratégias a grupos específicos, encontram-se a Portaria n 1.707/GM/MS, de 18 de agosto, e a Portaria $n^{\circ}$ 457/SAS/MS, de 19 de agosto do mesmo ano, às quais recorrerei no próximo subitem para delinear como os corpos trans são lidos e dirigidos pela CID e pelo DSM.

\section{3 "Mesmo calada a boca, resta o peito": encontros e desencontros dos corpos trans no SUS}

Como mencionado anteriormente, os corpos trans passaram a ser escrutinados a partir do teor que o prisma científico prioriza. As corporalidades passam a ser vistas como um emaranhado de questões que, apesar de circunscreverem-se na dimensão da experiência, são avalizadas quanto à pluralidade da questão - formando, como se existisse, uma conjuntura trans.

Essa consideração é terminantemente fundamental para pensarmos neste trabalho, pois dá relevo à necessidade de um olhar compreensivo para as existências trans, à medida em que encontramos, nas narrativas, problemáticas que evidenciam que o corpo trans passa a ser naturalizado a partir da categorização do binômio homem-mulher.

Assim, podemos observar que essa construção de corpo revela que a questão das corporalidades trans se encerraria aos e nos cânones do dispositivo saúde, pois, como vimos no subitem anterior, há uma demarcação e um cerceamento dessas experiências, na busca de uma veracidade que se legitima a partir do que se empreende para ele.

Nesse sentido, importa ressaltar como as instituições públicas de saúde, no Brasil, enveredam pelo cuidado destinado a essa população em especial. Ao que parece, há uma naturalização da transexualidade e da travestilidade como restritas à condição de alterações corporais, nessas instituições. O que pretendo dizer com isso é que, nessas práticas, fica evidente que a saúde prioriza uma "construção" de um corpo, tendo como finalidade neste a possibilidade de "sanar" uma problemática evidente. É como se cuidando da necessidade de readequar esse corpo a uma identidade que não condiz com o sexo biológico, a saúde estivesse garantindo direitos às pessoas trans e travestis.

Como vimos com as entrevistas de Fernanda, Joyce e Eduardo, para além de questões voltadas à hormonização, cirurgias de redesignação sexual ou cirurgias de 
feminilização/masculinização, há uma parafernália de nuances que tangenciam os serviços de saúde para a população trans. Tais questões sinalizam a necessidade de olhar, de compreender e de cuidar de práticas que não se limitem a um saber-fazer, mas que possam construir modos outros de dialogar com a própria população, reverberando uma possibilidade de articulação conjunta $^{79}$.

Decerto, as diversas práticas oriundas do campo da saúde sinalizam a diagramação, a correção e o reparo destes corpos. Na tentativa de se articular com estratégias que visam garantir o direito da população trans, o Ministério da Saúde, em 18 de agosto de 2008, cria a Portaria ${ }^{\circ}$ 1.707 e, em 19 de agosto de 2008, a Portaria $\mathrm{n}^{\mathrm{o}}$ 457. Tais portarias concretizam, em parte, possibilidades para pessoas trans iniciarem acompanhamento em torno das readequações corporais direcionadas à identidade de gênero. No entanto, estas possibilidades ainda não são uma realidade para a maioria.

As portarias sinalizam e apontam para a necessidade de olhar para estes corpos nas esferas do processo transexualizador, instituindo providências para implantação do serviço. No entanto, indicam uma série de considerações prévias para que esse "direito" seja garantido. Escolhi algumas dessas considerações para levantar algumas questões, brevemente. Na Portaria $\mathrm{n}^{\mathrm{o}} 1.707$, de 18 de agosto de 2008 (revogada pela Portaria $\mathrm{n}^{\mathrm{o}} 2.803$, de 19 de novembro de 2013), encontra-se:

Considerando que a orientação sexual e a identidade de gênero são fatores reconhecidos pelo Ministério da Saúde como determinantes e condicionantes da situação de saúde, não apenas por implicarem práticas sexuais e sociais específicas, mas também por expor a população GLBTT (Gays, Lésbicas, Bissexuais, Travestis e Transexuais) a agravos decorrentes do estigma, dos processos discriminatórios e de exclusão que violam seus direitos humanos, dentre os quais os direitos à saúde, à dignidade, à não discriminação, à autonomia e ao livre desenvolvimento da personalidade;

Considerando que o transexualismo trata-se de um desejo de viver e ser aceito na condição de enquanto pessoa do sexo oposto, que em geral vem acompanhado de um mal-estar ou de sentimento de inadaptação por referência a seu próprio sexo anatômico, situações estas que devem ser abordadas dentro da integralidade da atenção à saúde preconizada e a ser prestada pelo SUS;

Considerando a necessidade de se estabelecerem as bases para as indicações, organização da rede assistencial, regulação do acesso, controle, avaliação e auditoria do processo transexualizador no SUS.... (Ministério da Saúde, 2008, versão online).

\footnotetext{
${ }^{79}$ A articulação das práticas em saúde com a população atendida tem um caráter de um cuidado compartilhado, que se aproximaria da fenomenologia heideggeriana, quando diz que o cuidado (Sorge) pode se mostrar como ocupação (Besorgen) e preocupação/solicitude (Fürsorgen). Assim sendo, a dimensão do cuidado empreendida aqui vai na direção de compreendê-lo como solicitude, por entender que não é um "fazer por e para", substituindoo, mas aparece via acontecência do fenômeno na singularidade humana.
} 
A primeira consideração trazida aponta para a necessidade de pensar a saúde da população LGBTI, antes empreendida como GLBTT, dialogando com as estratégias que visam minimizar agravos às existências em decorrência do estigma gerado em torno dessa população, ao mesmo tempo em que considera a autonomia destas pessoas. Se pensarmos em toda história cultural, especialmente no Brasil, e fizermos uma ponte com as entrevistas realizadas, poderíamos hoje, em 2019 (onze anos depois), afirmar que uma portaria como essa garante a autonomia dos sujeitos?

Caminhando pela ideia de transexualismo enquanto objeto de categoria nosológica a ser alcançado pela portaria como forma de minimizar ou reparar danos à "saúde mental" das pessoas, a portaria estaria abrindo espaço para pensarmos "o sujeito" em sua "dimensão de sujeito" amparada pela igualdade das ações desenvolvidas pelas instituições de saúde?

A partir da compreensão de integralidade de ações e serviços, a organização da rede assistencial de saúde conseguiria atingir a população menos esclarecida ou desfavorecida de direitos? Essas ações que regulamentam o acesso à saúde estariam realmente possibilitando a travestis, mulheres transexuais e homens trans a possibilidade de alteração de seus corpos ou, mais uma vez, indicando formas e traçando perfis sobre e em torno do "verdadeiro sexo"?

De fato, todas as considerações acima referenciadas estão acossadas às considerações da CID e do DSM e, portanto, tangenciam uma compreensão sobre a transexualidade e a travestilidade a partir de pressupostos biologizantes, que se circunscrevem na lógica de reparo a dano, medida de ação frente a uma patologia.

$\mathrm{Na}$ Portaria $\mathrm{n}^{\mathrm{o}}$ 457, de 19 de agosto de 2008, há o delineamento de a que e como as ações são destinadas em cada órgão competente, as quais não fazem parte do objetivo deste trabalho. No entanto, é importante esclarecer que essa portaria aborda a Atenção Básica da Rede de Assistência de Saúde como a porta de entrada para iniciar o "processo transexualizador".

Todavia, essa portaria não cita a identidade de gênero travesti como público para tais procedimentos. Em pesquisa, encontrei a palavra apenas uma vez, relacionada à identidade de gênero, porém composta apenas no questionário de anamnese. Ao que parece, esta portaria dá indícios de que travesti é uma categoria de identidade de gênero marcada pela vivência e pela “declaração do outro". No entanto, quando não vincula o termo a outras identidades de gênero na mesma portaria, a identidade travesti parece não ser legitimada pelos cânones científicos e médicos, fazendo parte apenas do "imaginário" social ou de uma "confusão", para delimitar, por meio dos discursos, a quem pertenceria o transexualismo verdadeiro.

Como sabemos, tanto a partir do discurso social, como pela experiência de muitas travestis e pessoas trans (assim como vimos nas entrevistas com Joyce e Fernanda, por 
exemplo), recorrentemente há uma experiência prévia relacionada à procura e à entrada numa Unidade Básica de Saúde, no que se refere às alterações corporais que se adequem à identidade de gênero experienciada.

Nas narrativas de Joyce e Fernanda, encontramos diversos momentos nos quais elas afirmam que o uso indiscriminado de hormônios femininos é a realidade de muitas travestis e mulheres transexuais. Na maioria das vezes, esse uso é feito ainda na adolescência. Hoje, com o avanço da tecnologia e dos veículos de mídias, é bem mais fácil adquirir medicamentos e/ou outros elementos que possibilitam a construção desse corpo. As principais substâncias são o silicone líquido industrial (que é comumente utilizado como lubrificante de peças automobilísticas) e os hormônios femininos.

Tais substâncias, quando utilizadas sem acompanhamento ou indicação médica, podem gerar problemáticas no corpo e, consequentemente, na saúde de pessoas trans - especialmente o uso indiscriminado de silicone líquido industrial (SLI). Segundo Simpson (2015), é entre os anos 1970 e 1980 que o uso dessas substâncias aparece como um marco importante na trajetória de muitas travestis e mulheres transexuais brasileiras. Isso porque, no Brasil, o "modelo" de corpo feminino era e ainda é delineado pelas curvas acentuadas.

Segundo a autora mencionada, a injeção de SLI é uma alternativa mais rápida que o uso de hormônios para se construir este corpo. No entanto, ao que parece, inclusive nas narrativas de Joyce e Fernanda, o recurso da aplicação de SLI dá-se após o uso de hormônios, que é realizado por conta própria. Para ela,

Muitas [travestis e mulheres transexuais] faziam [e fazem] uso abusivo e indiscriminado de diversos hormônios, muitas vezes orientadas por outras trans mais velhas que já haviam utilizado esse ou aquele hormônio e sabiam que um era bem melhor que o outro etc.... elas recorrem a essas intervenções para que possam ter os corpos sonhados de forma rápida e barata. O SUS nunca compreendeu esse fenômeno [principalmente o da aplicação de SLI no corpo] como caso de saúde pública, até o movimento organizado pautar essas lutas em parcerias com outros movimentos e com alguns atores governamentais. (Simpson, 2015, p. 12, colchetes meus).

As lutas mencionadas pela autora sinalizam a negligência do Estado no que diz respeito aos modos de promoção e prevenção à saúde de travestis e mulheres transexuais, especialmente no tocante à ruptura com o método tradicional de saúde existente nas instituições públicas. Nestas instituições, como se sabe, o cuidado dessa população se volta à "readequação" corporal a partir da indicação de hormônios femininos.

No entanto, há de se considerar a afirmação de Simpson (2015) acerca da opção de métodos danosos à saúde, como o SLI, feitos por mulheres transexuais e travestis. Entendo que 
essa questão é revelada pela construção desse corpo de uma maneira mais rápida. Apesar de entender que a imediatez de seu uso se revela pela autoafirmação da pessoa, passo a compreender que o risco decorrente da escolha própria nos aproxima também de uma discussão. Cabe aqui uma questão: qual cuidado solicitam? Ou seja: como também posso cuidar de mim?

Esse apelo se refere à necessidade de encontrar estratégias que visem à minimização de impacto na vida destas pessoas, ao mesmo tempo em que possam direcionar outras possibilidades que garantam a redução de riscos e danos, como vimos na entrevista de Fernanda - até mesmo porque o compartilhamento de objetos perfurocortantes abre probabilidade de contágio de diversas infecções, inclusive HIV.

A utilização desses hormônios, como vimos, é uma realidade da maioria das travestis e mulheres transexuais ainda na adolescência. Mesmo que essa realidade seja evidente, é importante frisar que nem toda pessoa que se identifica como travesti ou mulher transexual faz uso de tais substâncias, uma vez que as corporalidades experienciadas são resultado de uma complexa identificação com o corpo, identidade de gênero, libido e, ainda, são amparados por uma ampla luta de poderes ${ }^{80}$.

A "construção" de um corpo faz-se via analogia à transitoriedade implicada pelas categorias homem/mulher, ao mesmo tempo em que delimitam e demarcam outras possibilidades a serem experienciadas, pois "as mudanças corporais não têm fim. O corpo nunca está 'pronto"' (Bento, 2017b, p.21, aspas da autora), mesmo condicionado ao uso continuado e acompanhado de hormônios, ou seja, torna-se também um cuidado reiterado pela própria pessoa.

Nessa direção, torna-se pertinente pensar a saúde dessa população, inclusive porque, como abordei anteriormente, nas portarias apresentadas, não há clareza quanto ao processo de hormonização direcionado a travestis, por exemplo. É possível se perguntar se tais portarias atendem a demandas específicas dessa população, justamente porque parece não dar conta da diversidade e das diferenças que advêm das travestilidades, às quais o movimento social organizado visa atentar.

Se temos como exemplo a descaracterização do endereçamento de práticas no processo travestilizador para a travesti na própria portaria, é porque torna-se necessária a "problematização da linguagem que cria e localiza os sujeitos que vivem esta experiência"

\footnotetext{
${ }^{80} \mathrm{O}$ poder aqui aparece como três dimensões: 1) estrutura das relações humanas, tal como aponta Foucault e Arendt; 2) poder do macho sobre a fêmea (ou do mais forte sobre o fraco), tais como os vividos em culturas patriarcais e machistas; 3 ) poder aquisitivo/financeiro, uma vez que são determinantes nas formas, condutas e usos de substâncias hormonais na redesignação do corpo ao gênero com o qual se identifica.
} 
(Bento, 2017b, p.39). Essas alternativas são tolhidas, pois, se houvesse a compreensão da distinção entre os diversos modos de experienciar gênero e corpo, talvez também surgiria a garantia de redesignação de um corpo frente às amarras sociais, movimentos coletivos e científicos que confabulam e direcionam a possibilidades fechadas de "fazer" um corpo.

Como já citado em outras ocasiões, a garantia de construir esse corpo que é circunscrito perante os ideais de masculino e feminino é, na maioria das vezes, redimensionada a partir da figura da bombadeira (Bento 2017a, 2017b; Pelúcio, 2009; Simpson, 2015). A construção social da bombadeira é acompanhada, muitas vezes, da figura de cafetina. Geralmente, uma mulher transexual ou travesti mais velha que detém saberes sobre o corpo (genérico): onde aplicar SLI, de que modo, com quais instrumentos, qual a quantidade correta e limite para cada "parte" do corpo e como deve-se cuidar do "pós-operatório".

Como apontou Fernanda durante a entrevista, o saber da bombadeira e das mulheres transexuais e travestis ultrapassam o saber médico, na maioria das vezes, justamente porque criam-se estratégias e fissuras no campo discursivo e preventivo que facilitam a construção de um saber sobre e do corpo. Ao que sabemos, a prática de bombação é ilegal, pois não há um saber "formalmente construído" e científico sobre a atuação, ao mesmo tempo em que escrutina o corpo, podendo levar a sérios riscos de saúde (inclusive morte).

A prática de bombação é, geralmente, associada à marginalização das travestis, mas poderíamos aqui evidenciar que se torna também uma marginalização (no sentido de "deixar à margem”) da vida. A prática está fundamentada na aplicação de um produto não utilizado e não indicado por médicos ${ }^{81} \mathrm{e}$, ainda, nos confins de lugares que não respeitam a normas de higiene, assepsia ou qualquer regulamentação para intervir num corpo humano.

É importante frisar que, por mais que esta prática esteja associada a sérios riscos de saúde, há uma constante necessidade de julgamento de escolha frente à utilização de silicone líquido industrial por parte de equipes de saúde. Quando, em algum caso de uso, há uma complicação maior em decorrência da aplicação de silicone, a equipe médica comumente olha como artefato de escolha da usuária, recriminando, violentando e negligenciando sua vida. A partir disto, podemos compreender que, talvez, a esfera da saúde, ao ditar normalidades e anormalidades na conduta humana, além de subtrair a experiência do(a) outro(a), retira também a sua própria condição de ter um corpo que lhe é legítimo. Mas, de fato, como uma travesti e uma mulher trans se reconhecem como um corpo legítimo?

\footnotetext{
${ }^{81}$ Apesar de haver, atualmente, vários casos documentados de apreensão de material e do profissional médico que pratica a utilização de silicone líquido industrial em pacientes.
} 
Talvez - ao que parece, aparece e desaparece nos escrutínios das práticas de saúde -, haja, nessa delimitação entre o corpo que se tem e o corpo que se quer, um complexo estado de massificação que garantiria e circunscreveria esse corpo já nos patamares estabelecidos pela distinção biológica e anatômica. Leite Jr. (2011), ao estudar o nascedouro das terminologias "trans" e "travesti", intenta ressaltar que, para as ciências naturais, há uma complexa preocupação em delimitar e categorizar estes corpos no que seria, eminentemente, organizado entre o "corpo de homem" e o "corpo de mulher".

Para ele, "é através dos conceitos e expectativas de gênero que se define inclusive o que são (ou não são) corpos humanos... quais os corpos, sexos e pessoas que não se enquadram dentro das normas de gênero" (p.122) e que podem ou não garantir o direito do corpo, ou melhor, a possibilidade de habitar o mundo pelo e no corpo que lhe faz existir enquanto pessoa, enquanto humano.

Tal atestação no campo científico, ao delimitar as (im)possibilidades para os corpos humanos, aponta para a desconstrução de outras existências que não correspondem à coerência preestabelecida. Assim, os corpos trans são lidos, configurados e alinhados como "monstros, freaks, queers, os seres abjetos que... não são compreendidos como possuindo o mesmo grau de humanidade." (Leite Jr., 2011, p. 122), passando a ser escrutinados desde o olhar até as possíveis intervenções concretas.

Diversas pesquisas (Brasil, 2015; Bento, 2017a; Bento, 2017b; Pelúcio, 2009) apontam que o recurso da procura por instituições de saúde, por parte de travestis e de pessoas trans, no geral, acontece quando há um estado de mal-estar evidenciado e grave. Raramente essas pessoas chegam às Unidades Básicas de Saúde ou a outros serviços “porta aberta” do SUS. Há de nos questionarmos e refletirmos sobre os motivos pelos quais esse movimento torna-se comum e presente nos serviços públicos de saúde.

Comumente, após essas portarias que evidenciam o cuidado e os direcionamentos em torno do processo transexualizador/travestilizador serem postas em ação, além da implementação da Política Nacional de Saúde Integral para Lésbicas, Gays, Bissexuais, Travestis e Transexuais, pela Portaria $\mathrm{n}^{\circ} 2.836$, de $1^{\mathrm{o}}$ de dezembro de 2011 (Ministério da Saúde, 2011), há certo “descompasso" no que tange às práticas direcionadas a esses segmentos. Como sabemos, por muito tempo, a população LGBTI foi lida a partir do boom da infecção por HIV e Aids, resultando em formas de reparo no modo de se produzir saúde, especialmente nos países das Américas.

Tais compreensões - acossadas a uma ideia de vulnerabilidade, extraída a partir do que se configurou como "grupo de risco" - resultam em ações que geram estigma a essa população, 
prevalecendo o cuidado e vigilância em torno da necessidade de "proteger" a população do "mal" HIV/Aids. Nesse sentido, seriam práticas de "cuidado" em saúde ou práticas de prevenção de saúde?

Tais práticas passaram a privilegiar estratégias que interagem com essa perspectiva, dialogando com notórias perspectivas excludentes. Assim, no campo da saúde, a população LGBTI parece estar fadada a duas pontes de partida: 1) oriundas do "cuidado" em ISTs, HIV/Aids; 2) processo transexualizador/travestilizador.

Este caráter é revelado, evidentemente, por direções tomadas por profissionais de saúde que se apoiam em perspectivas médico-explicativas, em sua maioria, para questões do viver cotidiano - resultando em desamparo no "cuidado integral" às existências de pessoas LGBTI, além de tomar estas duas "pontes de partida" como demarcadoras da diferença.

Em minha experiência como psicólogo, comumente escutei de usuários e usuárias dos serviços públicos de saúde que há um contínuo espaço de negligência no modo como os profissionais lidam com a população LGBTI. Quando sabem ou percebem, pela presença, que a pessoa é gay, bissexual, travesti ou trans, especialmente, os profissionais costumam questionar em seus atendimentos se a pessoa é portadora do HIV ou se mantém relações sexuais com mais de um parceiro por $\mathrm{ano}^{82}$.

Pelo que fica evidente, podemos compreender que o dispositivo saúde, ao conservar e direcionar práticas que se mantêm destinadas numa perspectiva de reparo, implicam tanto no sentido deste endereçamento, quanto no modo como cada usuário(a) recebe esse "acolhimento". A naturalização e assimilação da população LGBTI pelo prisma HIV/Aids, ao que parece, fragmenta a procura dessa população por cuidados básicos de saúde, como também minimiza a aderência a esses serviços. Assim, a saúde de LGBTIs - em especial a de travestis, mulheres transexuais e homens trans - é permeada por entraves que substancializam tais existências, revelando o desamparo em torno dessas experiências em saúde cotidianas.

Esse discurso que se ampara e, ao mesmo tempo, resulta na prática cotidiana de profissionais da saúde pública delega "couraças" aos corpos, tornando-os abjetos em si. O destino desta prática está alinhado com o olhar de condutas que são norteadas pela naturalização das identidades, normatizando o que se entende como "ideal" masculino e/ou feminino e, consequentemente, direcionando intervenções a serem realizadas no e para o corpo.

\footnotetext{
${ }^{82}$ Segundo a OMS, uma pessoa é considerada promíscua se manteve/mantém relação sexual com três ou mais pessoas durante o mesmo ano. Esse, inclusive, é um dos critérios de exclusão adotados por centros de doação de sangue, no Brasil.
} 
Assim, percebe-se que se cria um "dispositivo" na saúde, caracterizando-se como um constructo de saberes que amarram e formulam perspectivas que não conversam com a realidade vivida dos sujeitos (Bento, 2017b). O chamamento que as instituições públicas brasileiras de saúde fazem frente a demandas de travestis, mulheres transexuais e homens trans "apaga a legitimidade da pluralidade, uma vez que põe em funcionamento um conjunto de regras" (p.43) e interpela sobre a veracidade que garantiria a "condição trans".

Apesar disso, na Política Nacional Integral LGBTI, encontra-se disposta no Artigo $3^{\circ}$ a participação política da população na construção de estratégias que garantiriam ações em saúde, respeitando os direitos humanos e assistindo a determinações sociais que minimizariam danos e sofrimento. Nesse artigo, encontra-se assinalado a intersecção do direito à saúde e de outras nuances. Chamo a atenção para os incisos III, VI e IX:

III - inclusão da diversidade populacional nos processos de formulação, implementação de outras políticas e programas voltados para grupos específicos no SUS, envolvendo orientação sexual, identidade de gênero, ciclos de vida, raça-etnia e território;

VI - difusão das informações pertinentes ao acesso, à qualidade da atenção e às ações para o enfrentamento da discriminação, em todos os níveis de gestão do SUS;

IX - fortalecimento da representação do movimento social organizado da população LGBTI nos Conselhos de Saúde, Conferências e demais instâncias de participação social (Ministério da Saúde, 2011, versão online).

Como toda política redimensionada em estratégias, especialmente em serviços públicos, todo e qualquer direcionamento deve ser resultado de uma constante discussão com a comunidade, os movimentos e os serviços que a representam. No tocante à construção da Política Nacional de Saúde Integral LGBTI, decerto, há a participação do movimento organizado que, consequentemente, cobra por alternativas e novos planejamentos que garantam a integralidade das ações futuras ofertadas.

Chamo a atenção para os três incisos acima por tratarem dessa participação efetiva dos movimentos sociais. Questiono a garantia de ação de tais pontos, pois, ao que aparece nas pesquisas já citadas, nas experiências de pessoas LGBTIs e nas entrevistas realizadas nesta tese, não há uma (a)firmação do modo como os profissionais de saúde destinam suas práticas. Decerto, toda política é feita com e para pessoas. Ainda, toda prática é feita para, com e a partir de pessoas. Porém, como política efetivada pelo direito da população em questão, por que não há garantia no trato e na qualificação de instituições, profissionais e serviços? Poderíamos dizer que a saúde, ao trazer a política LGBTI para a prática, estaria realmente realizando política?

Indo por este caminho, como já tematizado anteriormente, percebemos que a instituição de saúde ainda precisa desassociar a ordem vigente que caracterizaria o humano (como a 
confusão de sexo e gênero), pois, ao tematizar a garantia de direitos da população LGBTI, entra em questão o poder que se empreende em torno dos discursos que ditam os corpos e as sexualidades.

Nesse sentido, há uma característica aproximação da saúde com uma linguagem e práticas violentas, visto que, ao fragmentar o seu sujeito-objeto de estudo, também deixa a ver a despersonificação da condição humana. Assim, mesmo que os discursos que regem as práticas façam jus ao que se pensa em termos de garantia de direitos, a prática, amparada pela lógica de quem a conduz, pode não fazer sentido quando não implicada nas experiências advindas desse viver cotidiano, especialmente no que diz respeito às existências trans.

Desse modo, mesmo que as ações em saúde a esta população sejam delimitadas e direcionadas por uma equipe interdisciplinar, importa destacar como o saber da psicologia contribui e legitima certos fazeres. A escolha por esse caminho aconteceu não só porque esta tese é de psicologia, mas porque é ela, como ciência e profisssão, que ratifica discursos e possibilita abrir fissuras nos endereçamentos de ações - assim como encontramos nas narrativas de Joyce, Fernanda e Eduardo.

Por um lado, a psicologia assemelha-se ao discurso médico vigente, perseguindo a lógica da patologização como oriunda da personificação que estruturaria a personalidade, acossada ao desequilíbrio, à perversão e ao fetiche. De outro, encontramos a psicologia que destina ações junto à comunidade e a movimentos organizados, permeada pela necessidade de construir fazeres anteriores ao saber científico. É sobre esse jogo de poderes e discursos que tratarei a seguir.

\section{4 "Silêncio na cidade não se escuta": o discurso psicológico e a vigilância dos corpos trans}

Conforme evidenciado anteriormente, é chegada a hora de navegar por mares intranquilos. Como psicólogo, vejo-me na necessidade de iniciar esse momento da tese como um (g)rito de passagem entre "quem sou antes de entrar no mar" e "quem sou após imergir sem saber nadar num oceano aberto".

Por muito, como expus na introdução, as questões relacionadas aos estudos que tangenciam a temática de gênero e sexualidade fizeram (e fazem) parte de minha experiência. Carregar na existência o peso de um corpo gay fez-me abraçar e rejeitar caminhos e questões. A psicologia ajudou-me a compreender que o lugar e o instrumento de ação do psicólogo é ele 
mesmo, é no seu corpo-junto- $a$ que carrega a condição primeira e última de existir enquanto tal.

Essa compreensão resultou numa série de incômodos, dos quais precisei desvencilhar do olhar atento, curioso, malogrado, matizado e multifacetado que a formação traz. A forma "bruta" e "radical" disseminada nos fazeres domesticáveis, que a psicologia, durante muito, aprimorou-se em fazer, não fazia sentido quando me eram cobrados resultado, respostas ou soluções para fenômenos da vida. No entanto, a mesma falta de sentido trazia-me o desconforto em não saber e em não poder construir uma direção para aquilo que me era cobrado.

Foi a partir da prática em assistência social que percebi que os humanos, quando retirados seus direitos fundamentais de subsistência, encontram na re-existência um modo de existirem. Ao resistirem, existem e insistem na legitimidade de suas escolhas tornarem-se próprias, não como resultado ou efeito de causas anteriores, mas como possibilidade de poder dizer "sim", "não" ou "sim-não" ao mesmo tempo.

A experiência de fazer parte de equipes multiprofissionais trouxe-me a feliz possibilidade de trabalhar com assistentes sociais. Foi então que eu vi que pouco nos é ensinado - a nós, psicólogos e psicólogas -, que a política se faz entre humanos. Tive, a partir daí, outra compreensão para o meu fazer. De fato, por entre os caminhos inóspitos e difíceis, entendi que a prática psicológica fundamentada única e exclusivamente em teorias não consegue dar conta do humano. É solitária. É alheia. É forasteira.

Em dois mil e dezoito, aos passos de caminhar na companhia desta tese, encontramos no grito "Ninguém solta a mão de ninguém!"83 um sentido para habitar o difícil e o inóspito. Com esse grito, a comunidade LGBTI de movimentos de esquerda, junto a outros movimentos de minorias, clamam pela primazia do direito legítimo de viverem tal como são, tal como se pode ser. Em meio à confusão notória que as Eleições de 2018 possibilitaram, foi construído um muro simbólico que separa as pessoas pelo olhar demarcador da diferença, refletindo na comunidade LGBTI (em especial à diversidade travesti e trans) um certo descontrole em relação a sua existência - como se a vida passasse a ser vivida a partir dos apontamentos que subgrupos maioritários definem e delineiam.

Nessa direção, penso que a psicologia tem um papel fundamental na tentativa de tematização e construção de uma ação que aconteça fundamentada numa perspectiva ética que

\footnotetext{
${ }^{83}$ Slogan criado e disseminado nas redes sociais no dia do resultado das Eleições de 2018, quando o então presidenciável Jair Bolsonaro (PSL) vence as eleições e coloca em questão os direitos das existências de minorias brasileiras. O slogan advém das lutas desses grupos minoritários como um grito de apelo à resistência, frente a um modelo fascista de governança de Estado.
} 
reivindica a coexistência do outro-no-mundo, abrindo horizontes para articular, refletir, endereçar e possibilitar o estranhamento.

Dito isso, apesar da intranquilidade cotidiana que alimenta o caos contemporâneo, fazse necessário repensarmos nossa prática. Repensar a prática esbarra, contudo, na nossa formação, que aprisiona e direciona para alguns elementos entendidos como fundamentais para a prática psicológica, mas que não se mantêm por si só, quando esta tropeça na realidade vivida pelas minorias, em especial as brasileiras.

Como sabemos, a psicologia toma para si, primeiramente, os ideais das discussões científicas positivistas para responder a demandas humanas. Encaminhar questionamentos no que diz respeito ao modo de vida contemporâneo acontece quando surge uma reviravolta provocada pela construção de políticas públicas, especialmente de saúde, educação e segurança, que priorizam as camadas sociais ditas minoritárias e periféricas.

Com o início do SUS, em 1988, diversas possibilidades surgiram no campo da saúde, inclusive no campo da psicologia. Esta ciência e profissão, habituada a estar inserida em consultórios particulares e corporações, necessitaria incorporar-se ao modo territorial de se compreender saúde, principalmente no que diz respeito à prática psicológica na atenção básica.

É por esse caminho que, enfatizando a necessidade estabelecida pela OMS da "saúde" como "completo estado de bem-estar biopsicossocial", a psicologia se insere na comunidade, aproximando e centralizando de seu fazer as existências periféricas. A entrada no campo da atenção básica põe em xeque os notórios elementares conhecimentos advindos das diversas teorias, pois começam a surgir problemáticas sociais que pedem por esclarecimento e atenção, especialmente no campo comumente conhecido como "saúde mental".

Aqui, como a saúde - tanto como instituição, quanto como prática - acontecia conjuntamente ao firmar-se enquanto contraponto binomial do conceito saúde-doença, tornavase necessária a ênfase nos processos corporais, pois seria a partir deles que se poderia compreender o complexo bem-estar em funcionamento ou, tal como fala Foucault (2017), seria no corpo que tais noções seriam escancaradas, ao retratar a dinâmica de instauração da vigilância dos e para os corpos.

Nessa perspectiva, a psicologia entraria como uma disciplina que estaria aquém dessas confabulações do campo da saúde, justamente porque seus fazeres científico, metodológico e interventivo se dariam na direção de reparar e tratar o "sujeito psicológico" e sua anormalidade. Por mais que a evidência da caracterização da doença estivesse no corpo, enquanto envoltório material, seria às especificidades "psicológicas" que essa disciplina destinaria suas intervenções. 
Em trabalho anterior (Melo, 2015), tematizo a estranheza e dívida da psicologia para com os estudos do corpo no decorrer da história, especialmente no que diz respeito à dimensão da ação clínica em contextos de corpos periféricos brasileiros. Ao que parece, a formação de psicologia, até hoje, pouco se destina a tematizar o corpo enquanto um objeto de estudo e de construção de reflexão, pois aprisiona sua dimensão a um significado dado previamente pela materialidade. Assim, do corpo sabemos aquilo que, de fato, acontece pela espacialidade corpórea, ou seja, o corpo físico, enquanto há um esquecimento da existencialidade do corpo, ou do corpo vivido.

Por esse caminho, penso que é por meio da tentativa de enclausuramento do corpo pelas ciências naturais que nós, psicólogos e psicólogas, nos afastamos da tentativa de caminhar pelo olhar atento e curioso para as questões que transitam pelas corporalidades. Como discutido antes, há um descompasso em toda cadeia de ensino científico que não ampara essas dimensões e não abre espaço para pensarmos a cotidianidade dos corpos, tal como sentem, falam, gritam, narram, existem.

Ao escutar histórias como as de Fernanda, Joyce e Eduardo, sinto-me inquieto e incomodado. Questiono como seria possível pensar uma clínica, ou melhor, a clínica psicológica, senão pelo prisma do acontecimento - acontecimento este que só seria possível quando houvesse possibilidade do encontro com o outro, com o alheio, mas que ao mesmo tempo também é nosso, comunga de nossa carne e faz-se pelo nosso olhar julgador de analistas.

De fato, estes "corpos estranhos" (Louro, 2007) subjazem não somente à diferença anatômica habitual dos corpos divididos como homens e mulheres, mas a partir também do nosso olhar estranho que direciona formas de coerção, aprisionamento e confusão. Por entre esses muros que a lente compreensiva de nosso olhar tecnicista esbarra, há uma série de tentativas de garantir a fabricação de corpos que seguem por uma lógica específica de recorte (tal como a tentativa de amontoar uma orientação sexual a uma identidade de gênero, por exemplo).

Assim, a fabricação dos corpos trans e travestis acontece quando há a iminência do olhar psicológico sobre as demandas de veracidade destes corpos. Bento (2017a), ao apontar para a psicologia como uma demarcadora de discurso que dialoga com a patologização das existências, questiona o lugar das teorias psicológicas como mote central de discussões que aprisionam o psicologismo a uma "natureza humana". A autora também sinaliza que tais discursos científicos têm um lugar ratificado de poder, podendo falar e dizer sobre algo.

Para ela, "Os discursos universalistas têm em comum a produção de um outro pelo esvaziamento das singularidades.” (Bento, 2017a, p.43). Entraria em jogo, assim, a construção 
de teorias filosóficas e psicológicas que deveriam orientar práticas que produzem discursos de veracidade frente ao que tornaria legítimo o reconhecimento legal e social de identidades impostas - e por que não opostas, se pensarmos que elas não fazem parte do emaranhado construído pela cisgeneridade?

Quando trago essa fala da autora, questiono também qual o meu lugar e em qual momento vi-me na tentativa de construção de sinais que direcionariam minha prática. Lembro que ao entrar de paraquedas como psicólogo no Centro de Cidadania LGBTI da Prefeitura Municipal de São Paulo, não tinha clareza quanto à necessidade de desconstruir a sexualidade frente aos paradoxos que ela mesma traz. Eu não sabia a diferença - se assim poderia dizer entre uma mulher transexual e uma travesti, por exemplo. Achava, antes dessa entrada, que uma pessoa que se reconhecesse como trans não se encaixava naquele corpo biológico e, obviamente, teria repulsa a sua genitália, carecendo de uma cirurgia reparadora; enquanto associava a figura da travesti à pessoa que não via essa repulsa como um motivo de reivindicar uma construção cirúrgica de seu corpo.

Ao lado desse meu "achado", que estava muito mais na confabulação de psicologismos identificados por mim, os quais advêm de uma formação centralizada na identificação de linhas transitórias do normal e do patológico que a psicologia retoma, também estava outros discursos que alinhavavam o que este ideal pressupunha, tais como o discurso do direito e o da medicina.

Foucault (2017) dirá que esses discursos não só geram poderes, como são propriamente poderes. Entra em jogo, assim, uma disputa que retomaria o lugar do qual se fala, quem fala, por que se fala e para quem se fala. Entendi que o que pensava previamente não fazia sentido algum, pois partia de um lugar que não retomava a comunhão com o "para quem" se fala. Foi a partir da minha prática em psicologia com travestis e mulheres transexuais (em sua maioria, profissionais do sexo) que comecei a compreender que essas "diferenciações" pensadas eram não somente sem sentido, como também carregavam uma ação violenta.

Assim, penso que as psicologias que caminham na tentativa de tematizar esses corpos frente aos ideais canônicos de categorização para indicar o verdadeiro gênero não só disponibilizam pensamentos advindos de achados psicológicos para o corpo e patologizam existências, como concretizam discursos e práticas violentas que dizimam travestis, mulheres transexuais e homens trans.

Torna-se necessário pensarmos eticamente o nosso fazer, pois, quando disseminamos discursos vazios que incitam o poder de quem fala e por que se fala, entra em jogo não somente a naturalização da estranheza gerada para esses corpos, como também a impossibilidade de experienciar uma existência legítima. Tais discursos, quando tematizam e categorizam o corpo 
em seu mostruário material, geram inúmeras consequências para a população de travestis e pessoas trans, entre elas o suicídio - que, na verdade, é mascarado com esse nome, na tentativa de apagar o assassinato social que essas práticas testemunham.

A engrenagem que gera a desvalorização dos corpos trans e a caracterização natural e violenta dessas existências propõe uma luta constante para ampliar atributos humanos para a "humanidade" (Bento, 2017a). Perseguindo essa lógica cerceadora, a ratificação desses discursos, que acontecem sem a participação política, não traria, assim, uma possibilidade de atribuir humanidade a esses humanos.

Esses achados da naturalização corpórea, que caracteriza a humanidade do humano, estariam associados à materialização de práticas que convergem para o indicativo de que os corpos trans seriam uma caricatura de corpos asseados. Para Leite Jr. (2011),

\begin{abstract}
A busca pela verdade última, encontrada seja na biologia ou na psique, independentemente de qual verdade for, é a busca pelo exercício do poder legítimo, ou seja, o mais aceito e menos questionado por se originar convencionalmente de um discurso 'legítimo' sobre uma verdade considerada 'legítima'. A noção de verdade dos discursos sobre o sexo e gênero é tautológica; ela cria a si mesma como um saber que justifica seu poder (p.178).
\end{abstract}

É nesse sentido que compreendo que a busca de identificar a veracidade de identidades como ação que possibilitaria a construção de corpos, por parte das psicologias, estaria associada não só à vigilância social ou à violenta marginalização de corpos periféricos, como também se acossa à criação de uma higienização de sexos para corpos que carregam, em si mesmos, a condição de suas mentiras.

Nos centros de transgenitalização/redesignação sexual ou em serviços de hormonização/terapia hormonal, a entrada do(a) profissional de psicologia deveria estar, nesse sentido, direcionada a recolher histórias do cotidiano dessas pessoas. Essas histórias deveriam servir, nesse caso, não como geradoras de documentos que padronizariam e encontrariam a gênese da questão trans, mas que indicariam que suas histórias de vida dizem de experiências que performatizam a desigualdade do modo como se vive, que essas vidas são precariamente vivíveis singularmente.

Essa breve análise respinga também no nosso fazer ético de, inclusive, redigir tais documentos. Quando escrevemos sobre alguém, esse documento diz respeito à história de vida dessa pessoa. Os cânones das instituições de saúde, com o passar do tempo, foram criando formas coercitivas de controlar as pessoas por meio de documentos, tais como os prontuários de atendimento. 
No que concerne à prática psicológica em instituições que tematizam as existências travestis e transexuais, especialmente as de saúde, há uma centralização do discurso que pressupõe a documentação de histórias de vida desses sujeitos precários. Dois documentos, em especial, são solicitados pelo regime institucional para que a pessoa seja destinada ou não à terapia correspondente - seja para pessoas que buscam hormonização, seja para as que estão em filas de espera para fazer cirurgias de redesignação sexual pelo SUS, ou até mesmo para aquelas e aqueles que desejam retificar o prenome civil. Esses documentos são: o parecer e o laudo psicológico.

O Conselho Federal de Psicologia, pela Resolução CFP nº 007/2003 (revogação da Resolução CFP n ${ }^{\circ}$ 17/2002), delimita e institui quatro documentos decorrentes da avaliação psicológica: declaração, atestado psicológico, relatório/laudo psicológico e parecer (embora compreenda que a declaração e o parecer não são decorrentes de uma avaliação psicológica propriamente dita).

Comumente, como citado anteriormente, os dois documentos destacados que direcionam as existências travestis e trans são o relatório/laudo (especialmente no campo da saúde) e o parecer (principalmente nos campos do direito e/ou assistência social). Conforme disposto, o CFP destaca que o laudo se trata de "uma apresentação descritiva acerca de situações e/ou condições psicológicas e suas determinações históricas, sociais, políticas e culturais, pesquisadas no processo de avaliação psicológica" (p.7), enquanto o parecer refere-se a "uma questão focal do campo psicológico cujo resultado pode ser indicativo ou conclusivo" (p.9). Ou seja, os documentos dizem sobre um resultado atestado a partir de uma atestação do(a) profissional.

Indo para os objetivos de cada documento, encontramos que o laudo deve

apresentar os procedimentos e conclusões gerados pelo processo da avaliação psicológica, relatando sobre o encaminhamento, as intervenções, o diagnóstico, o prognóstico e evolução do caso, orientação e sugestão de projeto terapêutico, bem como, caso necessário, solicitação de acompanhamento psicológico, limitando-se a fornecer somente as informações necessárias relacionadas à demanda, solicitação ou petição. (p.7)

Enquanto o parecer objetiva

apresentar resposta esclarecedora, no campo do conhecimento psicológico, através de uma avaliação especializada, de uma "questão-problema", visando a dirimir dúvidas que estão interferindo na decisão, sendo, portanto, uma resposta a uma consulta, que exige de quem responde competência no assunto. (p.9) 
Portanto, entendo que o laudo conduziria a uma resposta conclusiva sobre um projeto terapêutico a ser desenvolvido, levantando, assim, uma categoria nosológica (patologizando as existências travestis e trans, tal como vimos quando discutido sobre as estratégias de categorização da CID-11 e do DSM-5); enquanto o parecer narra uma compreensão sobre determinado assunto, construindo pontes entre o que colhe de narrativas e o que as teorias indicariam como prisma norteador.

Do ponto de vista das relações humanas, pensar a construção de tais documentos poderia sugerir um posicionamento político, por indicar uma ação conjunta, construída aos passos do testemunho, tornando-a autêntica perante os discursos que legitimam a condição humana como trans e travesti. No entanto, questiono a atribuição da construção de tais documentos como moduladores e ratificadores dos mesmos discursos que vigiam e punem, justamente porque, como sabemos, se a identidade de gênero é (ou seria) autodeclarada, não haveria sentido em tematizar um parecer ou laudo para responder a pedidos alheios.

A meu ver, quando solicitado pelos órgãos responsáveis, o(a) psicólogo(a) se tornaria um "perito" 84 , como se do discurso do outro levantasse suas suspeitas para indicar mentiras e verdades, ou seja, reconstruiria, assim, a “cena do crime”. Dessa cena, caberia, então, perseguir a lógica da linearidade do pensamento psicológico, indicando a quais corpos deferir uma existência trans e em quais corpos não ser possível intervir. De um lado, encontramos corpos potentes e aptos; de outro, estratégias de poder sobre corpos não-legítimos.

Assim, instaura-se uma milícia frente às existências trans. A crítica realizada por mim, anteriormente, quanto à dívida dos estudos da psicologia para o corpo (Melo, 2015), agora respinga na possibilidade de esclarecimento sobre formas e fôrmas que veiculam nas experiências desses corpos, especialmente no que diz respeito às travestilidades e às transexualidades. Essa atestação concerne à desnaturalização do diferente em meio à própria diversidade, pois "Os corpos trans seriam a própria materialidade da impossibilidade de assimilação.” (Bento, 2017a, p.59) e apontariam para a impossibilidade de esclarecimento frente ao que se conhece e se empreende dos e para os corpos "naturais".

Esse empreendimento está amarrado aos ideais das ciências naturais, que testemunham, veracizam e autenticam determinadas nuances em detrimento de outras. Obviamente, a naturalização dos corpos perante os ideais marcadores da diferença consubstancializa e aponta formas de coerção e correção. É a partir da correção do desnatural que se legitimaria, assim,

\footnotetext{
${ }^{84}$ Inclusive é esse o nome que se dá ao(à) psicólogo(a) responsável por testemunhar e autenticar documentos, no campo da psicologia jurídica.
} 
tais existências, delineando uma trajetória marcada pela aquisição de uma possível "realidade imposta".

É perseguindo essa lógica que a psicologia começa a tematizar os corpos trans a partir da avaliação psicológica, testemunhando o desnatural que precisaria ser corrigido. Empreendendo uma potente consideração de um saber-poder que carimba, assina e diz sobre o corpo do outro. A psicologia define instrumentos que mensurariam a quantidade de um "desejo trans" proveniente de um corpo que diverge de sua própria materialidade.

As atestações podem, então, ser encontradas na própria materialidade do corpo que soa como divergente da identidade de gênero. A avaliação psicológica entraria como rigor técnicocientífico que levantaria a "suspeita" sobre esse possível deslocamento. Instaura-se, assim, inquéritos documentais e testes psicológicos, que marcam uma construção teórica e interpretam a realidade frente ao "desejo" e ao simbolismo de um corpo, pondo "à prova uma técnica de intervenção ou uma antecipação precisa de resultados" (Figueiredo, 2014, p.13).

Antecipar-se com resultados seria poder inverter a ordem fazer-saber para saber-fazer, enfatizando a implicação que as teorias psicológicas poderiam ter em relação aos fenômenos humanos e ao mundo, desvinculando um do outro, pois não teríamos como compreender o humano sem seu próprio mundo experienciado em seu cotidiano.

Figueiredo (2014) dirá que esses campos de forças teóricas da psicologia buscam não só a veracização de discursos que categorizam sujeitos como sujeitos ou a-sujeitados, mas também se incorporam em práticas que visam controlar e definir paradigmas. Para ele,

A produção e a validação do conhecimento é, em última instância, o incremento do domínio técnico sobre a natureza, pressupondo a fiscalização, o autocontrole e a autocorreção do sujeito, que dão origem às preocupações epistemológicas e, principalmente, metodológicas, características da nossa época, e, numa decorrência, a um projeto de psicologia como ciência natural do subjetivo. (p.19)

Isso mostra a necessidade que a psicologia viu, no decorrer do tempo, de garantir o estatuto de ciência como propriedade, preocupando-se com a legitimidade de técnicas e teorias que potencializam seu saber. Essa validação do conhecimento enquanto científico, atrelada a epistemologias que decorrem de ideais positivistas, enclausura práticas e priva sociedades e grupos minoritários de suas próprias histórias e direitos culturais, pois à medida em que a psicologia direciona e modula padrões de resposta para comportamentos específicos, garante também a exclusão daquilo que não domina enquanto saber ou que não consegue dominar enquanto ação coercitiva. 
As análises em torno do corpo trans, para a psicologia, costumam fundar-se na perspectiva norteadora da patologia, levantando uma suspeita para o gênero, tal como foi discutido anteriormente. Analiticamente, a psicologia envereda-se ainda pelo caminho que decorre de sua impermanência em obrigatoriamente vê-se e fazer-se como ciência, centralizando, assim, o campo da sexualidade humana como um rol que determinaria quais comportamentos seriam dissidentes (Galli \& Vieira, 2013).

É importante tematizar aqui que, em São Paulo, com a entrada dos Centros de Cidadania LGBTI, os profissionais psicólogos começaram a repensar os instrumentos de avaliação (principalmente o parecer) que proporcionaria a possibilidade de retificação de prenome e de readequação corporal por meio da hormonização. Essa reflexão foi feita conjuntamente ao Conselho Regional de Psicologia ( 6 a região), que conseguiu levantar outras questões e propiciar formas estratégicas que atendessem à população de travestis, mulheres transexuais e homens trans, tais como apontam algumas pesquisas em saúde e direitos humanos realizadas nos últimos anos (Brasil, 2015; Concilio, Amaral \& Silveira, 2017).

A reformulação do modo de condução dos pareceres acontece conjuntamente a como os atendimentos vão se dando, ou seja, dá-se a ver em comunhão. Usuário(a) do serviço e psicólogo(a) escrevem e leem o parecer juntos, resguardando àquele(a) seu direito em dizer sobre si mesmo e autodeclarar-se a partir do gênero com o qual se identifica e pelo qual reivindica ou não a redesignação de seu corpo.

Assim, acredito que a experiência em psicologia junto à população LGBTI, ou melhor, junto à sua clientela, deveria atentar-se à experiência como passível e possível de ser compartilhada para tornar-se história. Aliás, quando escrevemos um parecer sobre alguém, não estaríamos contando uma história sobre a vida dessa pessoa e sobre para qual "moral da história" se aponta?

Figueiredo (2014) aborda a existência de epistemologias na psicologia que se enveredam pela hermenêutica. Acredito que a prática psicológica que se destina a estar junto a, se atentando ao cotidiano, lidando com o imprevisível dos fenômenos humanos, é uma prática que se faz acossada à hermenêutica, pois "é uma psicologia organizada sobre a noção de sentido e que se esforça para 'revelar e não para impor interpretações'.... Os intérpretes não revelam uma verdade, mas negociam um sentido" (p. 211). Isso aponta para a necessidade de pensarmos a ação clínica, ação esta que hermeneuticamente se constrói na política, entre humanos, "negociando um sentido" para humanos.

Uma ação política em psicologia caminharia, assim, na tentativa de enveredar por um sentido, uma compreensão. Só se compreende a partir do que se vive, de nossa experiência 
histórica. A compreensão diz também do modo como estamos afinados com o tempo-espaço, um jogo de lançar-nos àquilo que é posto ao humano: estar-no-mundo compreendendo sua existência e podendo dar um sentido a essa compreensão. Percebe-se, assim, que essa tarefa não é um caminho que parece simplesmente ser acatado pelo âmbito da cognição e do questionamento, mas diz de uma tarefa existencial: somos lançados no mundo empreendidos pelo endereçamento de compreender as coisas, o mundo, a nós mesmos e a nossa ação. 


\section{5 “ATORDOADO, EU PERMANEÇO ATENTO": a pluralidade da condição humana de e para o corporar de travestis, mulheres transexuais e homens trans}

Para acompanhar o pensamento tematizado anteriormente, encontrei em Hannah Arendt (1906-1975) uma possibilidade para compreensão de elementos que surgiram no espaço-tempo das historiobiografias testemunhadas. Pretendo, com isso, sinalizar uma possível compreensão que considere estas experiências do corporar como uma conjuntura amparada numa construção política. De fato, alinhavado às histórias narradas, sinto-me afetado por encontrar entre os fios tecidos espaços e fissuras que, ao olhar da psicologia, aparecem como caras, tais como: 1) possibilidades de pensarmos o poder e o biopoder sobre os corpos; 2) necessidade de articular as corporalidades a processos violentos que desconsideram as existências trans e travestis; 3 ) importância de pensar o fenômeno das identidades de gênero e construções de corpo como oriundas da relação entre as esferas pública e privada e 4) pensar a ação clínica numa perspectiva política.

Nesse sentido, entendo que alinhavar esses quatro pontos são importantes, na medida em que, ao escutar as histórias de Fernanda, Joyce e Eduardo, tornou-se possível dialogar com horizontes compreensivos que permitiram pensar os fenômenos que surgiram como repercussões singulares da pluralidade humana - se entendermos que as histórias narradas não finalizam ou concluem direções no campo das ciências humanas e da saúde.

Torna-se, assim, pertinente não só considerar tais fenômenos como oriundos das relações humanas constituídas aos moldes da itinerância entre o público e o privado, mas evidenciar que as próprias construções de masculinidades e feminilidades, que envolvem a esfera existencial tematizada no corpo, só são possíveis graças à condição humana da ação, consolidada quando há articulação entre os corpos políticos.

Perseguindo essa lógica, os quatro pontos em questão só se tornam elementos de nosso questionamento e reflexão quando entendemos que, na medida em que é possível transicionar um gênero pelos moldes corporais (materiais, simbólicos e existenciais), encontramos a possibilidade do novo surgir. Esse aspecto garante não só o espaço da ação ser realizada, mas da natalidade constituir-se, prévia e posteriormente - ou seja, indica a possibilidade de um nascimento ser dado a partir da construção de gênero, enveredada pela experiência cotidiana.

A natalidade é um conceito da obra arendtiana que se relaciona, como o próprio nome sugere, ao nascimento. Para a pensadora, o nascimento é a ordem natural humana que propicia o caráter da novidade. Quando uma pessoa nasce, o mundo já está configurado. No entanto, com este nascimento em questão, o mundo vivido torna-se "alterado", sugerido pela realização 
do nascimento. Assim, cada pessoa, enquanto ser-no-mundo, tem seu peso próprio no mundo e, ao mesmo tempo em que dele recolhe, também incita mudanças (Arendt, 2009; 2018a).

Desse modo, compreendo que o caráter da natalidade seria o maior acontecimento que provocaria uma ação-no-mundo. É nesse sentido que, quando focamos numa leitura de "humanidade" para os assuntos humanos, estamos em vias de conceber as relações que emanam da urgência do ato de viver para, a partir disso, possibilitar um espaço onde caibam todos e todas que destas relações participam.

Portanto, apesar de na obra de Hannah Arendt ser tematizado o "Homem" como um produto/produtor que se relaciona com o mundo no qual vive e incita ação, entendo que a linguagem humana não consegue atingir o real sentido característico do que comumente entendeu-se e produziu-se sobre este "Homem". Por isso, proponho considerarmos homens, mulheres e travestis como condições da existência humana, necessárias para entendermos que as trocas humanas se dão via participação política.

Não obstante, este pensamento repercute em nossa práxis psi, principalmente quando entendemos essa ciência como uma possibilidade de tematização de existências-no-mundo. É nessa direção que este trabalho caminhou e se presta a caminhar, pois com o diálogo costurado a partir das narrativas de Fernanda, Joyce e Eduardo, foi possível entender nossa clínica como profundamente amparada pelas trocas humanas, constituindo o caráter da política como o ethos $^{85}$ de nosso fazer.

Torna-se possível, assim, refletirmos a clínica psicológica pensada a partir da ação do(a) psicólogo(a), demarcando-a como um espaço existente que permitiria coconstruir esta mesma clínica. Não pretendo aqui propor uma clínica psicológica arendtiana, muito menos uma prática psicológica específica ou, ainda, uma clínica focada nos assuntos trans, mas fazer um convite para refletirmos o lugar sem lugar que impossibilita o lugar trans como temática clínica.

Portanto, penso que entremear as narrativas já analisadas à luz dos estudos que priorizam os assuntos das transgeneridades e corporalidades torna-se, nesse momento, solo profícuo para discutirmos os quatro elementos citados anteriormente. É importante ainda frisar que tais constructos - se assim poderíamos nomear -, focados da obra de Hannah Arendt, aparecem, neste trabalho, como uma possível organização de um pensamento que se dá em meio à construção ética e política de uma história contada, que, nesse sentido, está carregada e

\footnotetext{
${ }^{85}$ Ethos aqui compreendido como "ethos de humanidade" (Jaspers, 1991), que diz respeito ao compartilhar do cuidado da relação psicólogo-paciente, médico-paciente. Ou seja, é uma "morada demorada", no sentido que decorre do encontro entre humanos, possibilitando a apropriação de sua existência-no-mundo-com-outros (Morato, 2018).
} 
demarcada pela condição singular em meio à pluralidade humana. Logo, o sentido aqui encaminhado não se finaliza nele mesmo, dadas as condições sociais e historiobiográficas de Fernanda, Joyce e Eduardo.

\section{1 "Pra a qualquer momento ver emergir o monstro da lagoa": corpos e (bio)poder}

Existe absurdos hoje, mas naquela época, eles não tinham nenhum constrangimento de fazer isso, porque não tinha aparelhos de Estado que punissem, que vigiassem, entendeu?... Elas foram EXPULSAS da escola! Porque diretor não faz intervenção, coordenador pedagógico não faz intervenção, os pais não fazem intervenção, ninguém faz intervenção! Então, não tem ninguém POR, entendeu? Não tem ninguém POR essa pessoa... Essa pessoa já não existe! (Fernanda)

Os médicos me botaram na sala de homem.... Todo médico que chegava, voltava e ia lá na enfermeira. Tipo assim, olhava pra mim e 'Enfermeira!', aí a enfermeira ia e 'Não, é ele mesmo!'. Aí eu ficava lá toda torta. Era sempre tratada pelo meu nome de nascimento.... É tanta martelada, tanta coisa que a gente passa, velho, no mundo, que é melhor você ficar quieta que você não ser atendida. Tive vários constrangimentos. (Joyce)

Eles vão te olhar, sempre, querendo te analisar pra descobrir o quê que você é, sendo que é bem mais fácil perguntar o nome da pessoa.... Quando não conseguem ver no seu rosto, na camisa, olham na calça, porque homem é pênis! Esse é o reduto de um homem!... Antes até que eu conseguiria ter uma vida masculina na escola, caso eu tivesse visto essa abertura pra me relacionar com minha família antes, porque como eu não tinha apoio da família, não tinha como. (Eduardo)

Notoriamente, os trechos das narrativas acima demonstram a substância do poder nas práticas profissionais e nas construções familiares. Poderíamos afirmar, junto a isso, que o poder acontece onde existe relações humanas. Toda e qualquer relação humana é, portanto, arraigada de poder, que delega, dialoga e normatiza construções e intervenções nos espaços habitados. Nesse sentido, entendo que o poder transita tanto pelos espaços públicos - se pudermos conceber o dispositivo saúde como da esfera pública - como pelos espaços privados -, se compreendermos que a esfera familiar torna e transfere dimensões de vida a ser vivida em sua conjuntura.

Sendo o corpo a matéria humana vista, tocada, mensurada e objetificada, é nele que as relações de poder estabelecem suas "verdades". As corporalidades trans e travestis são, nessa perspectiva, ensaiadas à lógica estrutural da normatização destes corpos pensados e construídos na subjetividade das culturas pré-existentes. A lógica de corpo que dialoga com noções de verdades impostas e vividas são, para estas corporalidades, fragmentos sem sentido que cindem sua condição de existência.

O estatuto da verdade aparece não somente como uma marca do senso comum (o que seria comum a todos), mas como objeto de saber das ciências. Assim, as "forças de verdade" 
indiciam poder, na medida em que constroem direções e forçam estratégias, indicando quais vidas merecem - e devem - ser vividas (Butler, 2016).

$\mathrm{O}$ poder presumiria a configuração da vigilância estabelecida em torno de métodos próprios, que configurariam ideais sobre o humano moderno, com um recorte sobre sua construção subjetiva. Esta pressuposição, evidentemente, não consegue acompanhar a nova configuração social em que vivemos no mundo contemporâneo, inclusive porque este caráter subjetivo deflagra não somente as técnicas e métodos dispostos em decorrência da crítica ao modelo de projeto moderno, mas porque, sendo profundamente de natureza solitária, não acompanha estes mesmos sujeitos, que presumiria como objetos de sua empreitada científica.

Assim, o campo da sexualidade passa a ser uma destas empreitadas modernas, tendo nas questões voltadas às travestilidades e transexualidades o germe produtivo de discussões profundas e inacabadas sobre corpo e gênero. Foucault (2017) diz que a sexualidade aparece como uma luta de poder na medida em que sustenta a lógica dos escrutínios do lar, sendo ameaçada pela analogia entre público-privado. Em sua análise, as verdades já postas sobre o atributo sexual passam a ser conduzidas pelo Estado como uma forma de vigilância instaurada sobre e para os corpos, indiciando regimes que regulamentam estratégias de sobrevivência legitimadas pela bioética do poder.

Essa especulação foucaultiana, à qual recorro para tentar introduzir o pensamento arendtiano, entra em consonância com as práticas de profissionais de saúde e educação que, como falado por Fernanda, Joyce e Eduardo, deflagram e tornam obscuras as questões que se voltam ao corpo humano - especialmente quando este foge do esperado pelas diagramações de "corpo de mulher" e "corpo de homem".

As artimanhas do poder já nos fazem cair na própria lógica exposta pela linguagem falada. O substantivo "corpo" precisa de um adjetivo (mulher ou homem) para dizer sobre ele. A preposição " $d e$ ", nesse caso, indica o material que forma ou que constitui o objeto (corpo), sugerindo que o "corpo de mulher/homem" só existe se qualificado e materializado, especialmente pela relação que o caracteriza.

Para Arendt (2018a), o poder é materializado pela ação do humano-no-mundo em meio aos outros, pois ninguém teria a destreza de construir um poder sozinho. Com base nesse pensamento, circunscreve a lógica de compreendermos o poder como fruto das relações de troca entre humanos, ao mesmo tempo em que entendemos que tais trocas são feitas graças à constituição vivida dos indivíduos.

Destarte, a mesma lógica que transcorre das práticas educativas e de saúde caminha na tentativa de descortinar o poder como algo que é vertical, de cima para baixo. Entretanto, ele 
só acontece numa relação horizontal, na qual são feitas trocas a partir de discursos e ações que caminham comungando, entre si, posições e experiências.

Nas palavras de Arendt (2018a),

É o poder que mantém a existência do domínio público, o espaço potencial da aparência entre homens que agem e falam. O poder é sempre, como diríamos hoje, um potencial de poder, não uma entidade imutável, mensurável e confiável como a força [force] e o vigor [strenght]. Enquanto o vigor é a qualidade natural de um indivíduo isolado, o poder passa a existir entre os homens quando eles agem juntos, e desaparece no instante em que eles se dispersam. (p. 248)

Tais evidências tonalizam a matização de construções de achados científicos sobre as corporalidades dissidentes por também estarem situadas na forma como os discursos são produzidos, elencados pela parafernália do poder entre as relações que se estabelecem na esfera pública. Ainda que compreendamos que o poder acabe elegendo espaços e tempos para transcorrer de estratégias de resistência, como assinala Foucault (2000), ele também permite compreendermos como tais resistências revelam, para travestis, mulheres transexuais e homens trans possibilidades de denominar existências, ou melhor, de considerar no próprio corpo um espaço de mostração da política.

Indo adiante, Fernanda fala, em sua narrativa, do processo de bombação de seu corpo também como um espaço de resistência:

Aí ela disse assim, a bombadeira, 'Mulher, eu coloco um produto que não é silicone industrial, é Metacril.'. Eu sabia que não era, mas eu fingi. Pra mim, eu peguei essa mentira e transformei em outra coisa, como se fosse uma verdade, mas não é Metacril que tem no meu corpo. Eu não sou burra! (Fernanda)

$\mathrm{Na}$ construção/produção de discursos, o poder também entra como uma arma de resistência, na medida em que encontra, nos acordos, possibilidades outras de lidar com o próprio corpo. Aqui, a questão do poder se entrelaça com a resistência criada nas certezas "fingidas", na medida em que Fernanda, utilizando de tal "verdade" como uma artimanha, transformaria a instabilidade da prática de sua bombadeira em uma possibilidade de construção de um corpo re-verso. Mais à frente, também localizo em sua historiobiografia outra fala de resistência que permitiria a compreensão do poder como horizontalidade de saberes:

Porque o saber que se constrói, dentro do grupo [trans], é maior do que o externo... médico, enfermeira pode ter esse saber acadêmico, mas elas [travestis e mulheres transexuais] invadem até o saber acadêmico. (Fernanda) 
Para Jerome Kohn (2009) $)^{86}$, "Homens e mulheres politicamente reunidos na busca de um objetivo comum geram poder, que, ao contrário da força, provém das profundezas da esfera pública e a sustenta, como diz Arendt, enquanto eles permanecerem associados em discurso e ação" (p. 37). Isso tem a ver com o que Fernanda tematiza, e julgo importante para pensarmos os saberes construídos a partir da gestação de práticas que garantem a existência de algumas corporalidades trans e travestis.

A narrativa de Fernanda localiza-se onde o poder urge: da sustentação de discursos e saberes que são provenientes do status de publicização desses corpos - construídos à margem da heteronorma. Aqui, lembro Gadamer (2011), quando o autor traz o peso que a tradição representa à humanidade, pois tais discursos só são possíveis graças à articulação de saberes produzidos pelas próprias experiências de travestis e mulheres transexuais, na historicidade de suas existências, via apropriação desse poder que emana das relações.

Sigo essa perspectiva também pela experiência de Joyce, que comunica:

tomei hormônio da maneira que normalmente as meninas tomam por aí. Uma vai passando pra outra, uma aplica na outra... dessa forma assim! Desse jeito. (Joyce)

Percebo que os discursos aparecem revelados pela ação, como Arendt (2009) acreditava. A ação comunicaria a potência do poder, testemunhado pelas trocas políticas estabelecidas na tradição. Assim, tanto o que Fernanda como o que Joyce querem comunicar dizem do testemunho de um saber construído à margem que se centraliza pelo caráter de continuidade de histórias, da existência de corpos-resistência, indicando a política via "desempenho da árdua tarefa de manterem [corpos] vivos" (p. 134), legitimados pelo saber da experiência, apontando um espaço comum/comunidade.

No entanto, o grito de resistência, advindo da matização de corpos periféricos à heteronorma, quase nunca se torna barganha, quando se concentra na direção do poder cientificamente legitimado. Falo aqui dos discursos médicos, psicológicos e jurídicos. Tais discursos evidenciam o caráter de potência, construindo saberes a partir do empréstimo de realidades distantes dos jargões que se acossam.

Os mesmos discursos, em seu caráter de primazia do conhecimento, detêm sobre si e suas práticas a ratificação de verdades que se tornam vigilantes, sempre à espreita da naturalização das condições de vida. Essas condições estão impregnadas do que foi chamado de biopoder, questão geradora da biopolítica (Foucault, 2017).

\footnotetext{
${ }^{86}$ Em introdução do livro "A promessa da política” (2009), de Hannah Arendt.
} 
Para Duarte (2010), “o conceito de biopolítica... se tornou importante ferramenta conceitual para a compreensão e o diagnóstico das crises e mutações políticas do presente" (p. 205), pois tematiza a importância de pensar o poder como estratégia de resistência de políticas estatais. A biopolítica considera os sujeitos a partir de suas condições de vidas vivíveis, instauradas à luz da permissão de estratégias de resistência do Estado - que não só compõem o arsenal de saberes que destinam práticas para o corpo, como concretizam o aparecimento de verdades coercitivas e corretivas.

Disso decorre a insurgência da leitura para o corpo do(a) outro(a) e a estranheza gerada pela apropriação deste corpo, tal como levantei anteriormente sobre a condição de que "Nosso corpo nunca é nosso!"'. Assim foi com Fernanda, quando the foi burocratizado o acesso à hormonização e ao acompanhamento médico; com Joyce, quando olharam para seu corpo e o entenderam como matéria masculina; e com Eduardo, quando tentaram descobrir, pelo seu corpo, a qual gênero pertence (ou quando sua psiquiatra nomeia sua identidade de gênero):

A minha psiquiatra, que eu passava, até que me via... a minha transexualidade como nãobinária.... eu nem sei o que achava, porque ela dizia que eu era não-binário! Só que eu... não me identifico nem um pouco como não-binário.... Não fez muita diferença, na minha vida, o que ela acha ou não, então... a única coisa que muda na minha vida é ela achar que eu estou apto pra testosterona, daí muda muita coisa. (Eduardo)

O poder aparece, nesse sentido, seguindo a tese foucaultiana sobre o surgimento de estratégias de resistência, sinalizando que há, pela construção de saberes da ciência, uma determinação sobre o quê é do outro. Esta tese dialoga com os pressupostos arendtianos, quando reflete acerca das condições de liberdade nos espaços públicos.

Para Duarte (2010), a análise arendtiana sobre a biopolítica teria a ver com a condição de liberdade, pois esta esteve "experimentada de modo ativo pelos cidadãos no espaço público e constituiu-se como uma segunda forma de vida para cada homem da polis, o biós politikós, forma de conveniência na qual prevaleciam a ação coletiva e o discurso persuasivo entre iguais" (p. 105).

Seguindo essa vertente, entendo que a biopolítica interfere diretamente nos corpos, perfazendo estruturas que têm caráter de mensurar e vigiar os humanos e seus assuntos mundanos. $\mathrm{O}$ caráter oculto da biopolítica, nesta pesquisa, torna-se evidente quando a ciência se retira da reflexão empreendida pela experiência dos corpos trans e travestis, configurandoos como realidades dissidentes - das quais ninguém sabe falar, atender e acompanhar, mas sabe repreender, mensurar e medicar. 
O poder instala-se, assim, pela construção de saberes que impõem, normatizando vidas. Essa parafernália que, aos olhos foucaultianos e arendtianos, é tematizada como algo que acontece entre as relações, é apontada também por Agamben (2010) como advinda da condição da vida política do humano. Para o autor, os humanos estão em constante inclusão e exclusão na vida política, sendo esta cindida como zoé (o fato de viver comum a todos os seres vivos mundanos) e bíos (a maneira própria de cada indivíduo ou grupo viver).

Indo pela compreensão de Agamben, é possível entendermos como os corpos que fogem da naturalização imposta (tais como os corpos travestis e trans) são terminantemente cindidos na esfera pública, associados ao que ele denomina de vida nua. Compreendo que a vida nua se refere ao nascimento, uma metáfora que se aproximaria de quando "nascemos nus" e somos "vestidos" no decorrer do tempo - dadas as condições socioculturais pelas quais somos, previamente, embebecidos antes mesmo do nascimento.

A vida nua, portanto, subordinada à biopolítica, é entendida como sendo determinada pelo modo como as relações de poder são instituídas e testemunhadas na esfera pública. Assim, questiono como tal tese agambeniana poderia ou não dizer respeito ao conceito arendtiano de natalidade, como a ação, sendo o início de "algo novo" no mundo constituído com outros.

Ainda para Agamben (2010), "Uma das características essenciais da biopolítica moderna... é a sua necessidade de redefinir, continuamente, na vida, o limiar que articula e separa aquilo que está dentro daquilo que está fora” (p. 127). Quando analisamos os fragmentos de narrativa de Joyce e Eduardo, especialmente sobre as falas e práticas médicas, encontramos o entrelace no qual a biopolítica condiciona os corpos, delimitando quais são legitimados no espaço público (e, portanto, cidadãos passíveis de direitos) e quais são construídos à margem, desvestidos, nus.

Sobre isso, Duarte (2010) aponta que "O resultado final é que o moderno portador da cidadania não é o cidadão consciente e partícipe ativo da vida política, mas a vida nua do homem que nasce em determinado território, fato que traz consigo consequências biopolíticas devastadoras" (p. 297), pois, nascer em determinado país, notoriamente, delimitaria consequências para as existências que ali participam ou não dos acordos políticos.

Todvia, os cidadãos podem buscar "refúgio" em outras nações. Mas, quando falamos de lésbicas, gays, bissexuais, travestis, mulheres transexuais e homens trans, como refugiar suas existências, dadas as condições de corpo, gênero e orientação sexual dissidentes? Penso que essa questão está associada ao modo como se confundiu poder com violência, tal como Hannah Arendt tematiza e, nesse momento, chegamos ao segundo ponto de nossa discussão. 


\section{2 "De muito gorda, a porca já não anda”: discursos per-versos, práticas violentas}

No nosso país, se você for LGBT, você nem pode doar sangue!... Que você é uma bomba! Então você não pode doar sangue. Por exemplo, eu sou uma mulher trans e meu marido é um homem cis hétero e ele doa sangue. Por quê? Ele doa sangue porque ele nunca chegou lá e disse assim 'Sou casado com uma mulher trans'. Por isso que ele doa sangue. Entendeu? Se eu chegar lá, por conta da passabilidade, 'Tá aqui meu documento', com meu nome retificado, eles autorizam doar sangue. Mas se eu disser que sou uma mulher trans, você acha que eles vão coletar sangue? Lógico que não! (Fernanda)

$\mathrm{Na}$ hora da coleta de sangue, a menina me chamou pelo meu nome de documento. TODO MUNDO olhou pra minha cara.... Então, quer dizer, é normal, né!? A gente passar por constrangimento.... Então é normal chegar nos lugares e as pessoas continuarem do jeito que vai. Se for chamada pelo nome de documento, TODO MUNDO OLHA PRA TUA CARA!!! Tem funcionários que não fazem nem questão de tratar. (Joyce)

Tem que marcar a consulta, depois tem que marcar os exames. Demora muito! Pra depois pegar o resultado desses exames, o laudo desse clínico, o laudo da psicóloga, o laudo da psiquiatra... OLHA QUANTOS LAUDOS QUE UMA PESSOA PRECISA PRA VIVER!!! Pra ir lá no endócrino [médico], com todos os laudos pra mostrar... com OITOCENTAS PESSOAS atrás de mim dizendo ‘EU ACREDITO QUE ESSA PESSOA É TRANS!!!' (Eduardo)

Os trechos das narrativas acima apontam para a necessidade de discutirmos as práticas profissionais como oriundas de uma perspectiva discursiva que pode estar alinhada à violência. Nas historiobiografias, a violência aparece como um marcador, alinhavada a diversas circunstâncias que fragmentam as práticas e restringem vidas.

A violência é um fenômeno que se dá a partir das relações estabelecidas entre as pessoas e que, evidentemente, concretiza-se em subjugação dos corpos humanos - tanto na desconformidade com corporalidades, como na substancialidade do corporar. Confundida como sinônimo de "poder", "vigor", "força” e "autoridade” (Arendt, 2018b), ela perpassa não só as relações testemunhadas no espaço público, mas determina modos e moldes que aprisionam estes corpos aos espaços privados - inclusive à privação de si mesmo.

Quando Fernanda e Joyce falam sobre as práticas perversas em saúde, especialmente no que diz respeito à doação de sangue e ao nome, elas estão chamando atenção para pensarmos como o poder construído num grupo entra em ação sobre os corpos. No entanto, o poder perde o sentido nessas relações, se entendemos que ele é algo que se concretiza publicamente a partir das trocas e acordos realizados entre humanos. Aqui, o poder aparece confundido com o que seria violência.

Para Arendt (2018b), “O poder corresponde à habilidade humana não apenas para agir, mas também para agir em concerto. O poder nunca é propriedade de um indivíduo; pertence a 
um grupo" (p. 60). Seguindo essa perspectiva, entendo que o poder deixa de existir na medida em que ele é verticalizado, pressupondo um lado mais forte e um lado mais frágil - ou, dito de outra maneira, o lado do profissional e o lado do paciente.

É como tematiza Eduardo, ao dizer que, para seu gênero, seu corpo e sua vida serem legitimados, necessitariam de uma "fala" que diria sobre eles, testemunhando-os e considerando-os aptos a serem verdadeiros. Chamo a atenção para refletirmos que este lugar de "fragilidade", por ele referido, é comum de ser encontrado nas práticas em saúde, justamente por entender-se previamente que o(a) profissional é quem sabe dizer sobre o(a) outro(a). Entretanto, tais práticas, ao nortearem as concepções e assepsias para os corpos, estão mais próximas da violência que do poder, especialmente porque estes dois fenômenos não andam acompanhados.

O limite traçado entre o que se constitui como homem/mulher, masculino/feminino e macho/fêmea, reverbera, nestas práticas/ações/atitudes, a culminância da privação e afastamento das experiências sexuais e de gênero, bem como revelam no corpo a carga negativa destas mesmas experiências. Assim, é como se o corpo representasse o depositário que circunda masculino/feminino, para daí delimitar o limite do que seria "ser homem" e "ser mulher".

Poderíamos dizer, aos olhos de Arendt (2018b), que estas práticas perversas examinam os corpos pelos crivos de uma autoridade estabelecida pelo "reconhecimento instantâneo e inquestionável" (p. 63) de um saber que antecede a experiência de ser homem e ser mulher, dada a naturalização biológica que se torna o caráter diretivo e objetivo dessas práticas.

Essas ciências têm um peso no que diz respeito à confabulação existente, embebecendo práticas e discursos nas ciências humanas e sociais, como falei no capítulo anterior. Tais práticas e discursos tornam-se reflexos do que se constituiu como delegações formalizadas pelo binarismo homem-mulher, marcando pela atestação genital binária e gonodal as identidades e orientações sexuais, conduzindo atualmente a questões centralizadoras de debates contemporâneos (Bento, 2017).

Por esse mesmo caminho, o caráter da violência emerge por revelar-se enquanto atitude que compara a "verdade" sobre os sexos e as identidades, firmando a necessidade de caracterização específica entre a normalidade e o patológico. Estes intercruzamentos revelam uma penumbra em torno de tais existências, hierarquizando-as a partir das construções científicas sobre os corpos sociais (Beluche, 2008), revelados pelo prisma do imaginário social, não a partir da própria experiência do(a) outro(a). Tais práticas privativas, mais uma vez, denotam violência.

Para Chauí (2018), 
a violência não é percebida ali mesmo onde se origina e ali mesmo onde se define como violência propriamente dita, isto é, como toda prática e toda ideia que reduz um sujeito à condição de coisa, que viole interior e exteriormente o ser de alguém (p. 41).

É a partir das implicações que as pessoas, coletivamente, perfazem o que foi produzido em estruturas e funções sobre o humano. A compreensão do lugar reservado socialmente às ciências, neste sentido, constitui-se como uma "violência epistemológica sutil" (Bento, 2017, p. 48), pois, na medida em que direciona práticas coercitivas e vigilantes, reproduz invisibilidade e exclusão para esses corpos.

Esta "sutileza" da violência aparece em práticas profissionais diariamente, seja pela medicina, pela educação ou pela própria psicologia - especialmente, quando se exime de atendimentos a pessoas LGBTIs com o pretexto de não saber "lidar com esta população". Fernanda, Joyce e Eduardo frisam bem este lugar sem lugar encontrado nas práticas profissionais, sobretudo quando dizem sobre como são passados(as) de um para outro profissional, que geralmente não "sabem" lidar com seus corpos.

Compreendo isso, acossado a Butler (2017), ao tratar o caráter do ethos coletivo. A autora sinaliza que a violência é instrumentalizada e aparece associada a uma aparência de coletividade, testemunhada pela historicização dos sujeitos como "uma forma" de tornar presente esta mesma atitude, tornando-a pública e afirmativa.

Assim, este ethos pressupõe o reconhecimento de quais vidas são dignas de serem vividas, enquanto direciona modos e condições normativas para estas vidas serem autenticadas. Nessa direção, nem toda existência seria passível de ser reconhecida como vida, tornando-a marginal, reflexos do submundo (Butler, 2016). Tal violência ameaça a liberdade, construindo um cárcere privado do sujeito nele mesmo, encapsulando sua própria existência, anulando-a.

Por essa perspectiva, penso que a psicologia, enquanto ciência e profissão, desempenha fundamental importância na reflexão e construção de uma ação que aconteça alinhada a esta perspectiva ética que, ao mesmo tempo em que pensa sua práxis, também reivindica e testemunha a coexistência do outro-no-mundo - testemunho este que nem precisaria de um laudo ou parecer para ser legítimo.

Vou adiante com a narrativa de Eduardo...

Eu acho que os profissionais têm que estar aqui pra ajudar a gente na questão do viver! Ajudar como se estivesse ajudando uma pessoa cis .... Eu não quero saber do que minha psiquiatra acha... de se está certo ou não tirar meus seios. Eu que estou dizendo que está certo! É MEU CORPO!!! EU QUE TENHO QUE DIZER ISSO!!! (Eduardo) 
Apesar de Eduardo trazer, neste trecho, sua experiência com a psiquiatra, sou tocado pela sua fala, especialmente porque ele traz um chamamento para repensarmos nossa prática e os modos como construímos nossa profissão pelo caráter excludente e elitista que tangencia a esfera fronteiriça de nosso fazer.

Vejo como importante o incômodo trazido por ele, não só para repensarmos o fazer "psi” sobre os corpos, mas também para "abrir nossos olhos", acompanhando o olhar de quem nos procura. Entendo que uma prática que impossibilita o(a) cliente/paciente dizer sobre quem é ou que não se atenta à singularidade do(a) outro(a) intervém não só a partir do crivo de uma "natureza humana", bem como pressupõe a desapropriação da experiência deste(a) outro(a).

Essa possibilidade abre espaço para pensarmos a intranquilidade cotidiana que alimenta o caos contemporâneo, fazendo-se necessário rever nossa prática monopolizadora, primazia de uma psicologia construída aos moldes do psicologismo estabelecido por técnicas e teorias. Repensar a prática iria contra nossa formação cartesiana e elitista, que subjuga, determina e aponta para algumas nuances entendidas como fundamentais para a prática psicológica e seu modo de ação clínica, na direção do ethos humanitário.

É nesse sentido que compreendo que a constante busca de identificar a veracidade de identidades rebuscadas e associadas a construções de corpos, por parte das psicologias que avaliam a partir da escrutinação das experiências vividas, estaria associada não só à vigilância social coercitiva, como também à violenta marginalização de existências e corpos periféricos. Elas também se justificam pela confissão da sexualidade para corpos que carregam, em si mesmos, a condição de negação revelada pela higiene social - e por que não psicológica?

Tal higiene aparece também como oriunda da determinação dessas práticas, que reverberam um fazer em torno da dominação e coerção. Num primeiro momento, dominação e coerção seriam frutos, nessa perspectiva, de ações do poder científico. No entanto, elas são criações da violência, demarcadas pelo conjunto de amarras que elas delegam. Essa confusão ocorre, como diria Arendt (2018b), dadas as atribuições de compreensão de poder como violência. Contudo, violência e poder são contrários: onde um domina, o outro é coagido.

A violência aparece onde o poder está em risco, mas, deixada a seu próprio curso, conduz à desaparição do poder. Isso implica ser incorreto pensar o oposto da violência como a não violência; falar de um poder não violento é de fato redundante. A violência pode destruir 0 poder; ela é absolutamente incapaz de criá-lo. (Arendt, 2018b, p. 74)

Considero importante pensarmos o entremeio que difere o poder da violência, pois a confusão gerada pelo uso dos dois termos foi e é ainda palco de notórias compreensões 
deturpadas, principalmente quando falamos do poder do Estado. Por um primeiro olhar, a violência atravessaria o poder, na medida em que este provoca e incita formas de dirigir vidas. A violência decorre das mesmas relações instituídas e constituídas no espaço público, porém é fruto de uma arquitetura construída como recurso último, no intuito de conservar o poder intacto.

Entretanto, na compreensão arendtiana, a violência deflagraria o poder, pois este não necessitaria daquela para sua condução. Mesmo que um governo de Estado, por exemplo, se utilize de meios violentos como garantia de um poder inquestionável (tais como os governos tirânicos), a violência não é capaz de sustentar a suposta posição de hierarquia de poder. Ainda que a tortura seja um meio de dominação de corpos vivos e tome uma tonalidade de poder para o governo, essa é apenas uma falsa sensação, pois a violência não consegue abarcar o sentido do poder, tornando-se sem finalidade.

Como compreendido até aqui, entendo, pelas narrativas de Eduardo, Fernanda e Joyce, que o testemunho dos processos violentos aparece como oriundo das relações estabelecidas previamente às suas existências. Antes mesmo das primeiras histórias de pessoas trans e travestis existirem, o poder já estava imbuído e a violência já aparecia como recurso na tentativa de docilizar corpos de menos valia.

É importante tematizarmos isso, na medida em que, apesar de a natalidade ter o caráter da novidade, propiciando que o novo seja apresentado no espaço público - como já abordado anteriormente -, violência e poder já são enraizados num espaço social e cultural. Nesse sentido, poderíamos conceber o poder e a violência como sistemas pré-políticos? Arrisco a dizer que não, pois, à medida em que entendemos que poder e violência urgem das trocas humanas estabelecidas, eles só são possíveis a partir do caráter político destas relações.

Ainda que tentemos achar o real "nascimento" do poder e da violência, penso que se torna uma tarefa complexa, dadas as sutilezas que envolvem a penumbra dos assuntos humanos. Nos dizeres de Arendt (2018b), "nada poderia ser teoricamente mais perigoso do que a tradição do pensamento organicista em assuntos políticos, por meio da qual poder e violência são interpretados em termos biológicos" (p. 94).

O que a pensadora quer dizer é que ninguém nasceria com poder ou ninguém nasceria violento. Poder e violência estão amparados pelas relações em que surgem. É nesse sentido que podemos compreender que as experiências de travestis, mulheres transexuais e homens trans são palco para a discussão de poder e violência, dadas as considerações vivenciadas pública e socialmente. Se estivessem acossadas às experiências cis-heterossexuais, tal como a ordem vigente de nascimento, a travestilidade e a transexualidade não seriam solos profícuos de 
discussões e reflexões no cenário público, visto que indicariam corpos e vidas conformadas ao sistema normativo.

Adoto esta tese para tentar pensar como as práticas profissionais em saúde e educação estão alinhadas a esse modelo pré-configurado para entender o humano e endereçar intervenções, como Fernanda fala em sua historiobiografia:

Porque se o corpo docente dá suporte pra aluna travesti, os outros alunos baixam a cabeça, porque existe uma relação de poder. Quem tem poder é o corpo docente, na escola. Então os alunos, eles se intimidam, entendeu? Quando os alunos fazem isso na escola é porque eles têm o apoio do corpo docente. Quando a polícia bate em travesti é porque tem o apoio do prefeito, daquele que tem o poder. Entendeu? É a mesma coisa! É a mesma lógica! (Fernanda)

Ou como Eduardo também conta, ao falar que os corpos trans são subjugados a pesquisas no campo da saúde, que veem em seus corpos uma possibilidade de "crescimento científico" muito mais que um acompanhamento de experiências e cuidado com vidas:

Só que, nesses dois anos com a psiquiatra, no Hospital das Clínicas, é TOTALMENTE uma pesquisa feita! TUDO que eles fazem ali é uma pesquisa! Tanto que eles não atendem maior de idade agora, só de menor, porque de maior de idade eles já sabem a vivência. Eles agora querem saber qual a vivência trans de um menor de idade. ENTÃO, É UMA PESQUISA!!! Todos aqueles corpos são objetos de pesquisa! Aí, ficam dois anos deformando os seios dele porque A PESQUISA NÃO ESTÁ PRONTA! (Eduardo)

Percebo que, nas duas narrativas, a violência aparece como arma camuflada de poder. O poder do docente (falado por Fernanda) e o poder da psiquiatra (citada por Eduardo) desconsideram a legitimidade de suas existências, na medida em que há uma "dominação" do forte sobre o fraco: os alunos que baixam a cabeça para a ordem do professor e os pacientes que esperam pelas intervenções incertas de seus médicos.

Entendo estas narrativas como denúncias de um sistema que tonaliza quais práticas são apropriadas para as conjunções humanas, ao mesmo tempo em que desconsideram as existências de pessoas trans e travestis por tornarem-se menos importantes nos assuntos humanos.

É neste sentido que considero que a confusão entre poder e violência é um dos principais motivos geradores de prenúncios nas práticas profissionais, especialmente nas práticas "psi”. Reitero que o discurso psicológico é, muitas vezes, gerador de ações que orientam e determinam a "saudação de controle" de vidas, deslegitimando as experiências de relações simbólicas e concretas do viver cotidiano de travestis, mulheres transexuais e homens trans. 
Tais discursos são orientados pelas determinações anteriores que perfizeram a conjuntura de mundo comum, no qual habitamos e co-construímos. Nessa direção, entendo que as práticas profissionais em saúde e educação partem (ainda que se encontrem na tentativa de romperem com processos naturalizados) de uma condição pré-discursiva, pois são permeadas pelo caráter da tradição das ciências.

Os discursos - sejam de onde partam - estão ancorados com o caráter da política, pois estão condicionados aos modos privativos de concretizar ações nos espaços públicos. Assim,

Como a maior parte da nossa experiência com a política foi obtida no campo de batalha da força bruta, é absolutamente natural que entendamos a ação política segundo categorias como coagir e ser coagidos, dominar e ser dominados, uma vez que é nelas que o verdadeiro significado de toda a violência se revela (Arendt, 2009, p. 264).

Por este caminho, entendo que, quando Fernanda e Eduardo falam sobre os processos de práticas profissionais, estão pondo em questão o caráter violento que decorre destas práticas, pois ao mesmo tempo em que elas delimitam espaços para agir, também fecham possibilidades. Há uma dupla dominação por parte dos profissionais: seja das práticas, como das pessoas trans e travestis que procuram pelos serviços. Porém, há uma dominação que aparece anterior a estas duas: a do saber. Aqui, questiono: o saber, entendido como poder, não revelaria a possibilidade de a violência emergir?

A violência passa a ser concretizada quando os profissionais eximem travestis, mulheres transexuais e homens trans de contar sobre histórias e experiências, tornando-os(as) objetos de estudo aos crivos das ciências naturais, como Eduardo pontua. Ou seja, enquanto objetos passíveis de um olhar "neutro" - que, de neutro, nada carrega -, o calar da voz soaria como primazia de um saber que se constrói por uma falsa sensação de "poder"; no entanto, de fato, este saber parece ser construído e disseminado pela via da violência.

Vou adiante com a narrativa de Joyce, quando conta:

a gente está cansado de ver nas reportagens, crianças e adolescentes nas esquinas, beira de rua, se prostituindo... tanto meninas, como meninos. E quando eu vejo isso, eu me espanto 'Gente, ainda não mudou? Continua do mesmo jeito, oh!'. (Joyce)

Para Chauí (2018), “a violência não é percebida ali mesmo onde se origina e ali mesmo onde se define como violência propriamente dita" (p. 41), pois ela está interligada a diversos fatores que constituem a esfera social. As relações humanas, para a autora, estão sempre na iminência de efetivação da violência, especialmente porque a composição social do Estado 
torna as relações fadadas à anunciação das estruturas sociais - tais como o racismo, o machismo e o modelo patriarcal.

O sistema patriarcal delega normas e condutas para as vidas humanas, ainda mais se elas fogem da estrutura esperada. Incidem sobre as vidas formas regradas para se viver íntima e socialmente, de modo que o espaço comum passe do sentido de comunhão entre os acordos políticos para o que é massificado a todos. Assim, "O outro jamais é reconhecido como sujeito, tanto no sentido ético quanto no sentido político" (Chauí, 2018, p. 43).

O nome, o trabalho, os direitos e a voz de travestis, mulheres transexuais e homens trans são negados. Há um acordo preestabelecido oficiosamente na esfera privada, de tal modo que passa a se tornar oficial nos espaços construídos e vividos publicamente. Isso permite considerar que as práticas profissionais em saúde e educação estão amparadas por uma estrutura prévia, que desestrutura e tortura física e simbolicamente os corpos trans e travestis.

Ademais, os modelos que estruturam as práticas e a formação de profissionais localizam-se no discurso de subjugação: o tempo de espera para requerer um laudo, os processos demorados para se conseguir retificar o nome civil e gênero, anos de acompanhamento para indicação de cirurgias redesignadoras. A burocracia que domina as práticas apoia-se na dominação, na coerção e na vigilância, formas mitigadas de punir corpos abjetos.

Arendt (2018b) pontua que a burocracia aparece, no mundo contemporâneo, como um "formidável" modo de dominação. A autora diz que a burocracia indica um "domínio de um sistema trincado de departamentos nos quais nenhum homem... nem a minoria nem a maioria, pode ser tomado como responsável e que deveria mais propriamente chamar-se domínio de Ninguém" (p. 55).

Ainda que a burocracia apareça como o alvo, no que diz respeito às práticas de cuidado em saúde e educação (especialmente em saúde, dada a configuração das instituições e da rede, no tocante a laudos, políticas, regulamentações e encaminhamentos, por exemplo), ela não representaria o ponto crucial das indignações e inadequações dessas práticas e serviços oferecidos. A meu ver, ao tornar a burocracia institucional, o ponto da questão é, como diria Arendt (2018b), deixar a questão na penumbra, sem lugar de partida e sem destino, "pois aí não há a quem se possa questionar para que responda pelo que está sendo feito” (p. 55).

Torna-se importante, assim, concretizar a questão da violência como oriunda das relações suscitadas no decorrer dos encontros com as corporalidades travestis e trans nas instituições de saúde e de educação. Ademais, como já falado anteriormente, a presença, por si 
só, destes corpos nos espaços públicos, já testemunha os caminhos das diferenças que se tornam marcadores da não-conformidade normativa.

A presença destes corpos demarca uma construção outra de significados e sentido que o corpo toma. De um lado, é atribuído a ele a penumbra das "incertezas" sobre a que "sexo" pertence esses corpos e, de outro, permanece a perspectiva de que, por mais que ele se encontre na destreza em relacionar-se ao gênero com o qual a pessoa se identifica, muitas vezes cai na "armadilha" de se tornar o mais parecido possível ao padrão de corpo para os gêneros.

A construção do corpo trans e do corpo travesti passa por diversas incertezas, especialmente quando ao uso dos aparelhos e tecnologias utilizadas para sua readequação ao gênero com o qual se identifica. Tais incertezas, mesmo que por "escolha" de quem revela no corpo a legitimidade de sua existência, são deflagradas por ações agressivas para o próprio corpo, tais como as cirurgias de redesignação, mastoplastias, implantes de silicone e injeções de silicone líquido industrial (SLI).

Especialmente este último, como falado por Fernanda, é uma maneira agressiva que muitas travestis e mulheres trans encontram para construir um corpo com o qual se identificam. O recurso comum, entre elas, é o das tecnologias implantadas pelas bombadeiras, que, muitas vezes sem curso algum, dominam técnicas sobre a anatomia e fisiologia dos corpos.

Há, nesse sentido, um autoflagelo na construção do corpo que se quer. Este flagelo só é considerado dadas as impossibilidades que essas pessoas têm no que diz respeito às tecnologias científicas que poderiam ser utilizadas nos espaços da saúde e nos centros médicos, de maneira a garantir um cuidado que considere a implicação de seus sujeitos na sua própria existência e sua saúde.

Aqui, lembro de Arendt (2018a), quando a autora tematiza que a violência, na Grécia Antiga, estava sob condições também de nascimento e de liberdade. Para ela, "Ser pobre ou ter má saúde significava estar sujeito à necessidade física, e ser um escravo significava estar sujeito, também, à violência praticada pelo homem" (p. 38).

Entendo que ser escravo, a esta época, tornava-o findado em sua condição, denotando uma particularidade muito específica. Entretanto, poderíamos pensar os corpos trans e travesti por entre essa ameaça de um corpo escravo: escravo de um sistema normativo, escravo como desprovidos de diretos básicos, escravos da estrutura biológica de si mesmos.

Considero importante pensar que, nessa perspectiva, as corporalidades trans e travestis passam a ser inteiramente privadas. São, como Arendt (2018a) frisa em relação aos escravos, "prisioneiros da subjetividade de sua própria existência singular, que continua a ser singular 
ainda que a mesma experiência seja multiplicada inúmeras vezes" (p. 71), condicionadas à naturalização construída no mesmo mundo que compartilham física, mas não existencialmente.

É por essa imposição que acho pertinente considerarmos também como esses corpos são considerados nos espaços públicos, tendo, por consequência, a privação de si mesmos. No próximo ponto, tentarei construir um pensamento possível a partir de Agamben e Arendt, para refletir como o público e o privado relacionam-se na condição mundana, apontando um possível norte para compreendermos a subjugação das corporalidades trans e travestis.

\section{3 “Talvez o mundo não seja pequeno”: corpo público-privado}

Mas as pessoas estão sendo tratadas do jeito que estão sendo tratadas... na Praça da República, há três semanas, as meninas foram presas por estarem na Praça da República. [...] Então é como se os tempos tivessem atravessando e é como se a gente não estivesse mais em dois mil e dezessete, é como se a gente estivesse em mil novecentos e oitenta! Por que qual a justificativa de prender quem está na Praça da República? (Fernanda)

Não vamos ser hipócrita, né!? Ninguém vê, por aí, uma travesti do outro lado fazendo um cachorro quente ou um hambúrguer pra você. Você vê? Não vê! Muito raro! Fala aí pra mim! Não vê! (Joyce)

Hoje, pouco antes de chegar, inclusive, eu estava chorando porque eu estava com dificuldade de sair de casa, por conta de não querer sair com um corpo com o qual não me identifico, sabe? Porque a sociedade me olha diferente. Esse 'sair de casa' ser difícil é porque qualquer outra pessoa apenas sai pra fazer qualquer coisa, eu saio já esperando as análises. (Eduardo)

Considerando esse recorte de narrativas, não é preciso irmos muito longe para entendermos que os corpos trans e travestis denotam, no espaço público, a desnaturalização, a desestruturação e a desconfiguração de um corpo esperado. O testemunho de Fernanda evidencia o quanto os corpos das travestis e das mulheres trans são atravessados por tempos extremos, nos quais o poder da polícia e do Estado implicam as agressões física e psicológica dessas pessoas.

Viver, sendo trans ou travesti, representaria o viver como clandestino(a), exilado(a) em si mesmo. Poderíamos relacionar isso ao que Agamben (2010) questiona sobre o sentimento de pertencimento e não-pertencimento nos espaços públicos: “O que emerge nesta figura-limite é a crise radical de toda possibilidade de distinguir com clareza entre pertencimento e inclusão, entre o que está fora e o que está dentro, entre exceção e norma” (p. 31).

Penso que o que o autor quer dizer está fincado na compreensão de que, quando falamos de pertencimento, estamos em vias de considerar aquilo que diz respeito a aspectos com os quais nos relacionamos - seja nossa casa, nosso país, nossa família, nosso grupo social, nossa 
escola. Já quando falamos em inclusão, estamos falando em algo ou alguém que não faz parte desse grupo, mas que, por algum motivo, pode ser incluso e "fazer parte", mesmo que não compactue com toda peculiaridade que se revela no grupo.

Essa condição de pertencimento/inclusão tem a ver com a relação de exceção constituída com o que Agamben chama de bando. Para o autor, bando designa tanto a exclusão da comunidade, quanto o conjunto de pessoas comandadas por um governo soberano. Passo a compreender que as existências trans e travestis são consideradas como bando: banidas da conjunção simbólica e política dos "acordos entre humanos".

Segundo Agamben (2010),

Aquele que foi banido não é, na verdade, simplesmente posto para fora da lei e indiferente a esta, mas é abandonado por ela, ou seja, exposto e colocado em risco no limiar em que vida e direito, externo e interno, se confundem (p. 35).

Seguindo essa perspectiva, entendo que o que Joyce fala, na narrativa anterior, tem total implicação na relação de abandono. "Posto fora da lei", os corpos trans e travesti passam a ser indiciados ao risco iminente de viver pela exclusão. Corre-se o risco de entendermos que essas vidas (desqualificadas à vida) representam a "balbúrdia" de um sistema configurado, quando, na verdade, são oriundas da falta de sentido que se encontra anterior à formação desse sistema. Banido é o "posto fora da lei" e, portanto, não pertence ao bando, tornando-o abandonado, sem bando, excluído.

Ou seja, passa-se a considerar que, na medida em que essas existências convivem no limite da mesma polis, no mesmo espaço público, tendo no corpo o seu material biológico relacionado à condição de viver, nem sempre é possível dizermos que elas são consideradas pela comunidade política. É nessa direção que poderíamos também considerar que os espaços e/ou grupos minoritários que terminantemente relacionam-se entre si estão acossados à esfera privada do viver cotidiano, sendo excluídos da vida política e, portanto, da pública (Agamben, 2017).

Arendt (2009) ressalta que a convivência pública é a condição para os humanos "tornarem-se" humanos uns para os outros. Para a autora, "os homens realizam a sua plena humanidade, sua plena realidade como homens, não apenas porque são (como na privacidade da vida familiar), mas também porque aparecem” (p. 64).

Considero importante a tematização de Arendt para pensarmos como os corpos trans são deslegitimados nos espaços públicos. Quando Joyce traz "Ninguém vê, por aí, uma travesti do outro lado fazendo um cachorro quente ou um hambúrguer pra você. Você vê?", entendo 
que seu chamamento é justamente para pensarmos o apagamento e aniquilamento dessas existências nos espaços comumente participativos, tal como o simples fato de ter uma travesti na condição de vendedora de um cachorro quente. Ou seja, ela aponta que o lugar da travesti é um lugar sem lugar, demarcado pela sua existência da própria marca de ser abandonada no mundo em que coparticipa. Demarca-se, assim, a privação de sua vida, porém a publicização da estranheza que ela gera.

O mesmo acontece com Eduardo, quando conta que "qualquer outra pessoa apenas sai pra fazer qualquer coisa, eu saio já esperando as análises". Eduardo, ao contar isso, relaciona as análises que decorrem dos outros como sendo um julgamento testemunhado pelo espaço público. Ao mesmo tempo em que esta publicização é marcada pela condição da pluralidade, é também apagada pela diferença do modo "privativo" de seu corpo e sua identidade de gênero.

Recorrendo a Arendt (2009), esse caráter poderia ser compreendido à luz do senso comum, ou seja, do que é comum aos humanos. Conforme a autora, apesar da singularidade que todos nós carregamos, a pluralidade é a demarcadora de nossa existência-no-mundo. É, pois, a partir da constituição da pluralidade que os assuntos humanos são evidenciados e que as trocas e acordos são realizados, fundamentando a política e a comunhão dos espaços públicos. Portanto,

\footnotetext{
Assim como não existe ser humano como tal, mas somente homens e mulheres [e travestis] que em sua absoluta distinção são iguais, ou seja, humanos, essa identificação humana comum é a igualdade que, por sua vez, só se manifesta na diferença absoluta de um igual em relação ao outro (Arendt, 2009, p. 109, colchetes meus).
}

Seguindo o mesmo caminho, penso que os corpos são profundamente fincados na constituição da política, pois é pela iminência da igualdade - por serem corpos humanos, independentemente dos gêneros - que se faz possível testemunhar suas possibilidades-nomundo. A diferença dos corpos e a igualdade de gênero, mesmo que experienciados na esfera singular, são constitutivos dos espaços públicos e, logo, mudam o modo como as alianças políticas podem ser costuradas.

Essa costura social vai se fazendo a partir do modo como as relações públicas são construídas, de forma que o corpo passa a ser, publicamente, o depósito de expectativas, tornando-se demarcador de si mesmo, em seu "projeto privado". Assim, o corpo experienciado singularmente passa a ser palco de uma construção social que sai de sua individualidade para ser diagramado a partir de seu "uso" e "implicação" no mundo.

Seguindo essa perspectiva, trago a narrativa de Fernanda: 
Mulheres cis que trabalham com prostituição, também, que têm que ter o corpo perfeito, elas também procuram bombadeira. Não com a frequência da travesti. Porque a travesti, realmente, é uma readequação do corpo. A mulher cis é outra coisa: ela quer dar mais forma, ficar mais bonita. Não que a trans também não tenha isso em mente, mas é outra coisa você querer readequar seu corpo do que só estético....

Ela conta que há uma diferença, por exemplo, na relação de prática de bombação entre o corpo da mulher cis e o corpo da travesti/mulher transexual. O que ela aponta denota a demarcação da diferença. O corpo "perfeito" da mulher cis traz a forma estética como condição primeira de sua formação, diferentemente da travesti e da mulher transexual, que utilizam da prática de bombação como "a única forma de se construir o corpo que se quer". Para além de se ter o corpo que se quer, entendo que esse recurso é, também, uma forma mais "rápida" e sorrateira de publicizar e legitimar sua identidade de gênero no seu corpo, possibilitando ser reconhecida enquanto mulher/travesti.

Aqui, entendo que a passabilidade, já discutida anteriormente, também seria um "passaporte" para as pessoas trans e travestis participarem dos acordos políticos. Logo, os corpos da travesti, da mulher transexual e do homem trans passariam a ser visualizados publicamente, sendo reconhecidos ou não como corpos legítimos.

Uma vez que a passabilidade se torna o palco para a concretização de um corpo trans/travesti "o mais parecido possível” com um corpo cis, permite experienciar publicamente a condição de corpo esperado e, entrementes, de domínio público. Percebo, aqui, algo que se aproxima à narrativa de Eduardo, quando conta:

Não sei em outras realidades, em outras sociedades... mas NESTA que eu vivo está cada vez
mais difícil. Principalmente pelo machismo, porque se eu não for MACHÃO... se eu não vestir
as roupas que eles querem que eu vista, não sou homem.... os homens cis, as mulheres cis, a
sociedade, no geral.... Eu sempre luto contra o machismo dentro de mim, porque eu posso ter,
às vezes, um comentário ou comportamento machista. Como, por exemplo, quando passa uma
moça bonita na rua, eu me pergunto 'Por que eu vou olhar?'. Entende? Mas antes eu não me
perguntava. Hoje eu pergunto. Porque eu penso que não é uma exposição de carne!

Essa atestação de Eduardo vai ao encontro dos pressupostos de Butler (2015), quando a autora afirma que gênero é também performatividade. Para ser homem, mulher ou travesti, é preciso que, cotidianamente, se repita e se ateste publicamente o espaço privativo de sua singularidade (de gênero, de corpo, de identidade e, até mesmo de orientação sexual), espaço este que perfaz o diagrama da veracidade dos corpos e dos gêneros. 
Se passamos a considerar essa perspectiva, entendemos que o corpo, enquanto transeunte da esfera privada à esfera pública, relaciona-se à vida política, demarcada pela concepção de um corpo com sentido compartilhado, não mais privativo. Arendt (2018a) assinala que os assuntos humanos, na esfera privada, estavam dedicados aos confins do lar e da família, na Grécia Antiga. Com o passar do tempo, esses assuntos privados passam a perder força, especialmente com o advento do cristianismo.

Esta tese comunga com a tese foucaultiana, especialmente porque foi com o advento do cristianismo que os corpos passaram a ser vigiados, punidos e martirizados. O corpo, antes privado, passa a ser público: se confessa sobre ele e seus pecados; a Igreja detém poder sobre as práticas sexuais e reprodutivas; instaura-se a manipulação de práticas sociais a serem reconduzidas nos lares. Além disso, é a partir da dominação patriarcal do próprio lar que o corpo humano passa a ser associado à materialidade profana.

Nesse sentido, conforme Arendt (2018a), “A ascensão da sociedade trouxe consigo o declínio simultâneo dos domínios públicos e privados" (p. 318). Poderíamos, aqui, enfatizar como as concepções atuais, especialmente as médicas (discutidas anteriormente), sobre os corpos trans e travesti estão muito mais relacionadas à confabulação pessoal aos cânones privados do que à (im)permanência de desamparo do mundo público comum. Ou seja, torna-se muito mais fácil considerar os corpos trans e travesti à luz da normatividade estabelecida pelo "mundo de todos" do que pelo senso comum ou o que seria comum a todos.

\section{4 "Outra realidade menos morta": dos corpos travestis e trans para uma ação clínica e política em psicologia}

Mas depois de quatro meses, o professor continuava nessa lógica de violar esses direitos... o que a gente faz? A gente mete o decreto na cara, faz denúncia e grita mesmo com professor e diretor, porque ninguém é de ferro! (Fernanda)

Em todos lugares que chego, já vou logo informando. Há muitos anos! Há quinze anos... desde que eu me entendo por gente que eu sei que pode ser usado o nome social. Não sabia da existência da retificação, não tinha noção, mas do nome social eu sempre usei. (Joyce)

Ser trans é uma resistência. Ser LGBT! Ser negro e não alisar o cabelo! Deixar o cabelo natural... é uma resistência! Não deveria, mas é. (Eduardo)

Os encontros com Fernanda, Joyce e Eduardo perfizeram uma marca no modo como hoje compreendo a psicologia, minha prática, minha ação, minha vida. Esta pesquisa passa a ser não somente uma pesquisa, mas uma tatuagem em meu corpo, em minha existência. Sinto que a psicologia, por muito, eximiu-se de discussões profundas sobre existências dissidentes, 
periféricas, nômades. Aqui, nesse ponto, intento construir um sentido para pensar uma ação clínica em psicologia que se caracterize como coparticipativa, tal como compreendemos uma ação política.

É importante esclarecer que o que virá transposto a seguir não se presta a construir uma "clínica da transexualidade/travestilidade" ou uma "psicologia política", mas aponta direções para refletirmos sobre nossa prática a partir da experiência dos corpos trans e travestis. Entendo que esse movimento é necessário como possibilidade de repensar nossas práticas e construir um espaço de cuidado de nosso fazer.

A todo momento, na tese, o fazer e o saber estiveram atravessados, tal como uma rede costurada aos passos alinhavados dos encontros com Fernanda, Joyce e Eduardo. Para além de suas historiobiografias, o testemunho narrado possibilitou pensar como poderíamos, enquanto psicólogos e psicólogas, lançar um destino a nosso fazer, de modo que o saber prévio não tome e torne o corpo como mais um objeto de nosso escrutínio.

Diante disso, o pensamento de Hannah Arendt (1906-1975) possibilitou construir um olhar a partir de uma hermenêutica sobre os fenômenos que surgiram nos encontros. A atitude fenomenológica de lançar luz sobre o diálogo tecido propiciou um espaço de reflexão, de revisão e de re-cordação de nosso lugar ético e político frente às demandas humanas que encontramos e com a qual lidamos nos espaços públicos.

Assim, torna-se pertinente, depois de escutar, ler e reler estas histórias, apontar uma possibilidade compreensiva para os fenômenos das corporalidades travestis e trans. Ainda que não se finde em si mesma, essa compreensão me permitiu entender que se faz necessário tomar como bússola os humanos em toda e qualquer ação em psicologia (seja ela na prática psicológica ou na pesquisa). Ademais, esses corpos pedem por uma ação com sentido, revelada, neste trabalho, como uma condição plural de viver e habitar o mundo.

Os três trechos das narrativas dos encontros, dispostos acima, revelam a importância de uma ação, intervenção ou investigação serem postas aos modos do diálogo, ensejando uma perspectiva de enfrentamento e resistência. Com a população trans e travesti, aprendi que nossa prática deve ser revista diariamente, atentando não só à singularidade de cada sujeito em questão, mas também à sua perspectiva de experiência-no-mundo-com-outros. É para esse prisma que este ponto do capítulo se voltará.

Tais considerações perfazem uma construção sobre o sentido advindo das corporalidades travestis e trans, deixando espaço para discutirmos a ação clínica do(a) psicólogo(a). Ademais, é importante esclarecer que há um caráter peculiar nas práticas psicológicas que têm como espaço a sustentação de uma clínica que tenha a tensão das injustiças 
sociais e, portanto, políticas. Seguindo esse caminho, importa ressaltar o que compreendo por ação clínica, para, a partir disso, podermos pensar um caminho possível para esta ação.

Conforme assinala Barreto (2013), “'a ação clínica desloca-se do âmbito das teorias e técnicas psicológicas para aquelas da existência" (p. 39) e é considerada como a atitude e disponibilidade de um olhar atento e compreensivo sobre os fenômenos que surgem no cotidiano de sua prática. Ou seja, a ação do(a) psicólogo(a) se revela como o modo de estar afinado(a) em direção ao diálogo fundamental sobre a compreensão da existência-no-mundocom-outros.

Tomando Arendt como referencial, compreendo que a clínica psicológica é o espaço de encontro entre o mundo vivido cotidianamente e a ação que acontece nesse mesmo mundo. Como discorrido no capítulo anterior, a ciência cria arcabouços que, de modo diretivo, empreendem direções também no campo da psicologia. Essa "situação criada pelas ciências tem grande importância política. Sempre que a relevância do discurso está em jogo, as questões tornam-se políticas por definição, pois é o discurso que faz do homem um ser político" (Arendt, 2018a, p. 4).

Passo a compreender a ação clínica do(a) psicólogo(a) como política na medida em que encontro o percalço dessa ação como fundamentada nas relações plurais, possibilitando abertura para tematizar e compreender o mundo a partir de sua constituição revelada pelas estratégias de vidas. Isso permite entender que é a partir do caráter da pluralidade que a vida se torna elemento a ser tematizado pela significação no mundo.

Essa pluralidade só é possível, segundo Arendt (2018a), se acossada a uma ação entendida como constituinte da condição humana de existir. Juntamente com a ação, outras duas atividades humanas aparecem como fundamentais para a condição humana: o trabalho e a obra. Assim,

o trabalho é a atividade que corresponde ao processo biológico do ser humano.... A condição humana do trabalho é a própria vida.

A obra é a atividade correspondente a não-naturalidade da existência humana.... A condição humana da obra é a mundanidade.

A ação, única atividade que ocorre diretamente entre os homens, sem a mediação das coisas ou da matéria, corresponde à condição humana da pluralidade, ao fato de que os homens, e não o Homem, vivem na Terra e habitam o mundo. (Arendt, 2018a, p. 9).

Perseguindo essa ideia, é no caráter da ação que considero que a pluralidade humana se revela com mais peso, ou seja, é a partir das relações entre mundo-humano-outros que é 
possível compreender o mundo, o humano e os outros. É na experiência que se intercruza que é possível dialogar e testemunhar os modos de vida constituintes da tessitura mundana.

Os corpos trans e travestis testemunham na pele e na carne as (im)possibilidades sociais, demarcadas pela sujeição ao modo normativo a partir do qual as sociedades passaram a considerá-los e reiterá-los no passar dos tempos. Tal como Joyce conta sobre suas afetações e dilacerações de sua existência frente ao julgamento da equipe médica ou como Eduardo fala acerca dos olhares apontadores de sua masculinidade, entendo que a condição humana de quem é mulher transexual, homem trans ou travesti representa o avesso do avesso, avessado pela constituição de um corpo que é exilado em si mesmo e abandonado no mundo, junto aos outros.

No entanto, a pertinência, re-sistência e existência de travestis, mulheres transexuais e homens trans reiteram o respeito à história; prezam pelo o respeito às vidas assassinadas e àquelas que não puderam narrar sobre si mesmas; frisam o grito de permanência pela conquista dos espaços públicos; clamam pela justiça de seus direitos negados, incluindo suas vidas e o direito de existir. Assim, entendo que "A ação, na medida em que se empenha em fundar e preservar corpos políticos, cria a condição para a lembrança, ou seja, para a história" (Arendt, 2018a, p. 11).

Isto é possível, pois os discursos são amparados na ação humana, uma vez que discurso e ação fazem parte do mesmo material político e são retratados na medida em que os seres humanos agem-no-mundo. Na compreensão arendtiana, entre trabalho, obra e ação, é na ação que acontece a mais estreita relação da condição humana, justamente porque é nela que a condição de natalidade tem maior aproximação e implicação. Graças à condição de natalidade, é possível que os humanos possam iniciar e realizar algo novo, dadas as suas possibilidades de existência (Arendt, 2009, 2018a). Encontro, aqui, a possibilidade da aproximação entre Arendt e Agamben, como já explanado.

Como Joyce afirma, é em seu nascimento como travesti que é possível ser quem se é, realizar o que se realiza e agir no que é possível de sua ação. Sua narrativa mostra a possibilidade da compreensão fenomenológica existencial, na medida em que compreendemos que o humano só é sendo, realizando sua tarefa de existir-no-mundo-com-outros. Penso que se torna importante enveredar nossa compreensão fenomenológica por essa afirmativa, especialmente porque nosso discurso está amparado pela nossa prática e, mais ainda, acossado à nossa ação clínica.

Se entendemos nossa ação clínica como o espaço de realização de nossa atitude junto às existências, anterior às teorias e técnicas psicológicas (Barreto, 2013; Santos, 2016), passamos a compreendê-la como um modo de destinação a partir de um pedido ou solicitação (seja ele de 
uma pessoa em específico, de um público ou de uma instituição), e, assim, trazendo um caráter político em seu bojo.

Permaneço seguindo esta tese, por acreditar que existe um modo próprio de ser psicólogo e psicóloga de cada um(a) que está entremeado num caráter político - se entendermos que a formação em psicologia pressuporia as relações humanas. Esse modo estaria próximo a uma perspectiva ética e política, porém amparado pelo caráter originário do sentido de ação, tal como a perspectiva arendtiana.

Arendt (2018a) demarca que a palavra ação traz alguns significados importantes para pensar seu sentido. Diz ela:

o grego e o latim... possuem duas palavras totalmente diferentes, mas correlatas, para designar o verbo 'agir'. Aos dois verbos gregos archein ('começar', 'liderar' e, finalmente, 'governar') e prattein ('atravessar', 'realizar' e 'acabar') correspondem os dois verbos latinos agere ('pôr em movimento', 'liderar') e gerere (cujo significado original é 'conduzir'). (p. 234)

Em sua compreensão, Arendt questiona o emprego da palavra ação no decorrer do tempo, entendendo que ela passa de uma perspectiva de "movimento" para uma da ordem do emprego da "liderança" e "governança", tais como os verbos archein e agere. Na esteira desse pensamento, entendo que o sentido de ação que estamos convocando à reflexão refere-se ao segundo prattein e gerere ${ }^{87}$, empregados no sentido de "realizar" ou "conduzir" algo -, aqui, encontro um ponto em comum com o sentido de natalidade, enquanto proposição de "iniciar algo novo".

Esse início diz respeito não somente ao caráter da natalidade, mas do modo como somos convocados a responder demandas que pedem por uma ação clínica. Eduardo frisa bem essa necessidade em sua historiobiografia, especialmente quando conta da necessidade de que a psicologia tenha clareza do pedido que lhe é feito, antes de intentar veracizar um discurso que não lhe diz respeito, empreendendo um saber anterior a um fazer.

Aqui, lembro de Santos (2016), quando a autora pontua que o(a) psicólogo(a) “também precisa assumir a sua responsabilidade no viver cotidiano pelos espaços em que habita/transita. Sua ação clínica coexiste com uma atitude ético-educativa e política, a qual se mostra reveladora de uma singularidade" (p. 194). O que permite compreender que é a partir de sua clientela que o(a) psicólogo(a) gesta/nasce enquanto psicólogo(a), ou seja, é em seu modo de estar junto(a) que se torna possível (ou não) agir.

\footnotetext{
${ }^{87}$ Para Arendt, o sentido de gerere denota uma dupla ramificação: gerire e gerare (gerir e gerar, respectivamente). Assim, a violência, discutida anteriormente, aparece como fenômeno porque a compreensão de ação passa a ser tomada com o sentido de gerida ao invés de gestada.
} 
Indo por esse caminho, a ação clínica está terminantemente imbricada na política. Dialoga com o caráter da novidade, relação acontecimental que concretiza a possibilidade de trocas de experiência e compartilhamento de histórias. Nesse sentido, a ação do(a) psicólogo(a) é aqui entendia como um novo início que possibilitaria o encontro com a novidade, com a criação do presente, dando possíveis endereçamentos a uma destinação futura (Arendt, 2008, 2009).

Por esse percurso, compreendemos que a estranheza gerada em torno dessa ação reverbera o incômodo com as práticas coercitivas que a natureza científica promulga, alinhavando aos pressupostos de avaliação e mensuração de padrões comportamentais para atestação de existências.

Por outro lado, alia-se à ação, também, a oportunidade de abrir possibilidades para conceber a psicologia como uma empreitada reflexiva que recolhe narrativas/singularidades, sustentando tensões no amparo à diferença/diversidade/pluralidade. Assim, passo a compreender que a narrativa testemunhada pelo(a) psicólogo(a) possibilita a veracização de uma existência, autenticando sua existência legítima ${ }^{88}$. Tal atestação diz respeito à necessidade de compreendermos as existências trans e travestis como possibilidades outras de compreensão do corpo como político, ao mesmo tempo em que sinaliza e reverbera sua intensidade para pensar uma possível ação clínica do(a) psicólogo(a).

As tensões geradas em torno da clínica, enquanto atitude que destina uma ação política, referenciam a crise de produção de sentido (Francisco, 2012) que a psicologia encontra em seu fazer interventivo. Desalinhavar o nó existente entre concepções naturalistas que presumiriam as existências LGBTI - e, aqui, em especial, as existências trans e travestis - associadas a um aparato biológico causal dá indícios para questionar e assumir outras possíveis dimensões na clínica psicológica - e por que não médica? - contemporânea.

Isso permite-nos sair do lugar de poder concebido pelo crivo científico, assumindo um horizonte que permite veracizar e autenticar nossa prática, nossa clientela e a demanda advinda dessa relação. Assim, a via política da clínica destinaria uma "ação em conjunto, do 'compartilhamento de palavras e atos'. A ação... é a única atividade que constitui [o mundo]." (Arendt, 2018a, p. 245, colchetes meus), testemunhando (entre)linhas que fogem do saber previamente instituído pelos discursos teóricos e instrumentos práticos.

Nessa direção, penso que, quando estamos amparados à noção de clínica enquanto uma atitude entremeada a uma ação ético-política, podemos possibilitar o endereçamento de práticas

\footnotetext{
${ }^{88}$ Critelli (1996), como discutido no capítulo metodológico.
} 
que saem dos confins confessionais do consultório para uma abordagem construída em meio ao viver cotidiano. Entrementes, como aborda Santos (2016),

a ação clínica no viver cotidiano se mostra nos diversos modos de ser psicólogo, e comporta diversas modalidades de prática psicológica a partir das demandas que surgem ao caminhar com-outros, do que vai acontecendo no caminho - escutar o que se sucede como sendo digno de ser pensado (p. 198).

Tal compreensão justificaria a intercorrência de uma ação profundamente amparada na acontecência das experiências vividas no cotidiano político. Desse modo, penso, ainda, que é possível traduzir uma clínica que persiga a tentativa de construir um mundo corresponsabilizado pela pluralidade que nele habita e realiza ação.

Como sinaliza Arendt (2009), “A ação é absolutamente singular no sentido de pôr em marcha processos que, em seu automatismo, se parecem muito com os processos naturais, mas também no de marcar o começo de alguma coisa, começar algo novo, tomar iniciativa" (p. 167). Esta atestação entra em consonância com o que estamos discutindo acerca da tensão gerada na clínica psicológica - e, aqui, numa perspectiva fenomenológica -, uma vez que ela dialoga com uma atitude que parte de algo para se tomar um sentido, um caminho possível.

No mundo inóspito e estranho, ou melhor, no país caótico e nebuloso como o Brasil (tal como Fernanda e Eduardo pontuam em suas historiobiografias), a psicologia necessita considerar esses corpos, a partir das existências LGBTIs e demais atestações de gêneros e orientações sexuais, como possíveis acontecências do existir humano. Isso possibilitaria legitimar a psicologia em sua condição ética, clínica e política, junto a populações vulneráveis e negligenciadas.

Penso que, partindo de uma perspectiva que passe a compreender tais existências e corporalidades como oriundas de uma construção de corpo que sai de uma esfera biológica e anatômica, torna-se possível enveredar por uma ação clínica que se constrói no mundo que compartilhamos.

Assim, compartilho da tematização arendtiana acerca da ação política, por entender que a psicologia, enquanto ciência e profissão, testemunha lugares-limites no enfrentamento de circunstâncias do sofrimento humano. Entendo que esta tese se volta a uma particularidade específica - às existências trans e travestis, tendo um recorte sobre as corporalidades em questão -, no entanto há de nos questionarmos o lugar de ciência que a psicologia toma ao enfatizar as (in)verdades dos aparatos tecnológicos clássicos para compreender o humano que este mundo habita. 
Ademais,

não será característico da ação política, pelo menos em nossa época, ser destituída de quaisquer princípios, de modo que, em vez de brotar das muitas fontes possíveis de comunidade humana e se alimentar dessas profundidades, ela se aferra oportunisticamente à superfície dos acontecimentos cotidianos e se deixa jogar em várias direções...? (Arendt, 2009, p. 260).

A reflexão trazida até aqui dialoga com a tentativa de construir uma clínica que se desenha aos moldes do "mundo moderno", tendo a artimanha de questionar-se e refazer-se enquanto uma possível ação clínica e política. Construindo (im)permanências de agenciamentos para lidar com o viver cotidiano de sua clientela, a psicologia poderia - para além de legitimar o dizer do(a) outro(a) - testemunhar as histórias que recolhe em seu projeto de ciência e profissão.

Isso permite entender que a psicologia deveria partir do presente, do tematizado na intranquilidade cotidiana, evidenciando as determinações e circunstâncias sociais impregnadas nas vidas de seus sujeitos. Quando falo do presente, não retiro a importância de pensar sobre o passado, sobre a tradição (tanto de sua clientela, quanto dela mesma enquanto ciência), mas objetivo discutir sobre a importância de dialogar com as peculiaridades singulares das existências "contemporâneas".

Essa compreensão tem a ver com o sentido de ação de Arendt (2009), quando a autora reitera que o objetivo, ou melhor, o ponto de partida da ação "não está contido na própria ação, mas, ao contrário dos fins, também não se situa no futuro. Para ser realizável, ele deve estar sempre no presente, precisamente durante todo o tempo em que ainda não foi realizado" (p. 263).

Entendo, seguindo essa direção, que precisamos estar atentos e atentas à nossa ação clínica e ao modo como a endereçamos. Todavia, o enfrentamento da violência cotidiana que os corpos travestis e trans passam é demarcado também pela privação de seus corpos dos confins do discurso psicológico em voga, tal como os atestados nos manuais de psiquiatria abordados no capítulo anterior.

A vigilância da psicologia consigo mesma, portanto, necessitaria de partir de uma perspectiva ética acossada à política, por entender que nenhuma prática ou intervenção faz-se sozinha. Enveredando por essa dimensão, penso que a psicologia, enquanto lugar de destinação, traz a possibilidade de as histórias serem testemunhadas a partir de uma "fusão de horizontes", autorizando que as histórias se intercruzarem, dando espaço para a criação de um novo sentido (Gadamer, 2011; Santos, 2016). 
Assim, entendo que as particularidades das existências trans e travestis - especialmente as de Fernanda, Joyce e Eduardo - tematizam a importância de a psicologia questionar, revisitar e refletir sobre sua participação na construção de situações hermenêuticas que favoreçam o cuidado compartilhado e coconstruído via ação política. Ao olhar de Arendt (2018a), a ação política mostra-se como parte da vida dos seres humanos, existencialmente falando. Seria, então, a partir da ação política que se tornaria possível atestar a pluralidade humana, oportunizando a criação do novo em meio a esse plural. 


\section{6 "AFASTA DE MIM ESSE CALE-SE": um sentido para a pluralidade cotidiana de corporalidades trans e travestis - ou da ação clínica psicológica?}

Inicio este "capítulo final" sentado em minha varanda. Como um morador, observo as flores rosáceas que estão reluzentes com a macieza do sol que bate em minhas pernas e queima em sussurro. Por mais que tenha começado vindo de fora, olhando da janela, não termino no quintal da casa... Eu voltei para a varanda.

Olhar para minha pesquisa e para minha experiência como pesquisador, psicólogo e professor foi, necessariamente, notar a mudança que existe em mim. Minha vinda a São Paulo não foi nada fácil (quem me conhece sabe!). Desistir de um lar; desistir de uma cidade que amo; desistir de fazer parte de lugares; desistir de um emprego; desistir de relacionamentos; desistir de ser quem era? Eu nem sabia, na verdade, que estava desistindo de quem era. Desisti-me?

Por vezes, a palavra desistir soa-me como abdicar. Não sei se abdiquei de um cotidiano que, mesmo que fizesse sentido, queria mostrar-se de outra maneira ou se desisti de viver na conformidade e no comodismo deste mesmo cotidiano. De fato, minha vinda a São Paulo foi assombrosa. O imaginário que guardava da USP, da vida corrida, do amor que não teria em SP... Aqui eu encontrei acalento. Aqui eu saí do meu armário imaginário mais obscuro.

O início desta tese foi pesado. Antes mesmo de entrar no Programa de Pós-Graduação, fui questionado, durante a entrevista, sobre o porquê de estar me inscrevendo no Programa de Psicologia Escolar e do Desenvolvimento Humano, e não no de Psicologia Clínica. Não somente por a orientadora pretendida compor este programa, mas porque vi-me na necessidade de discutir a formação psi foi minha resposta.

Pode parecer estranho iniciar um capítulo de fechamento de tese desta maneira. Pode soar estranho colocar-me diante do olhar científico e acadêmico para fechar com questões como estas. Porém, embebecido pela discussão sobre a formação psi e nossa ação clínica, não teria como iniciar um caminho sem mostrar-me como o viajante que sou.

"Perdi" um ano de doutorado: sem saber por onde caminhar, o que necessariamente pesquisar, como conduzir minha pesquisa... Que equivocado! Não teria como conduzir minha pesquisa... Ela já estava me conduzindo! Fechei os olhos, os ouvidos, minha boca. Demorei um ano para me ver em minha pesquisa, fazer com tesão o que pretendia, esbarrar em diversas questões, mudanças, andanças, e, mesmo assim, continuar com o mesmo tesão. "T" de trans, "T" de travesti. 
Por entre os prédios da "cidade de pedra", questionava minha presença e percebia minha ausência. Durante este primeiro ano, escutei dos colegas de orientação como caminhar, por onde caminhar, o que talvez seria "melhor" ou "mais adequado". Mas esta pesquisa, ou melhor, estas pesquisas não eram a minha, não eram as que me viam, as que encontravam o T-são. Percebo que esse movimento de me perder foi justamente o de, possivelmente, encaixar-me ao menos num grupo: um grupo respeitado, um grupo coeso, um grupo almejado, um grupo forte, um grupo potente... e agradeço a meus colegas por este calor, por esta potência, por me abraçarem neste grupo.

O respeito que tenho pela pesquisa fenomenológica está nessas páginas que antecederam, nas que virão e no próprio viver cotidiano. Não teria como adentrar por entre estas três histórias se não fosse por este olhar que não foi ensinado, mas que foi vivido, comungado, compartilhado. Fernanda, Joyce e Eduardo foram as três pessoas que fizeram esta pesquisa ser sustentada e que me tocaram de um modo tão particular...

O caminho feito até aqui não é um mero parêntese, mas uma abertura para irmos até o quintal, darmos uma volta pela casa, pelos cômodos, voltarmos para a varanda e avistarmos as flores. Desvisto-me de meu casaco, as tatuagens estão feitas (existencial e concretamente) e percebo que, como narrador, precisaria comunicar estas vozes junto a elas.

O sentido de pluralidade retratado anteriormente e que decorrerá nas páginas seguintes dirá de meus encontros, de meu contato, de minha experiência, de nossas histórias; dirá do café de Fernanda, dos cabelos de Joyce, da presença de Eduardo; dirá de meu olhar, e, portanto, outras compreensões poderão surgir para quem ler - inclusive quando, talvez, um dia precise de um acalanto para minha r-existência.

As histórias que aqui se abriram levaram-me pela mão. Pela experiência de Fernanda, Joyce e Eduardo, dei voltas no mundo. Nada do que tinha até então estudado ou escutado dava conta dos nossos encontros. Tornava-se um acontecimento: tudo relacionado a ele e elas, as histórias escutadas inúmeras vezes no áudio gravado, as linhas transcritas nesta tese. As coisas começaram a ter um sentido, a tomar forma, a apontar uma direção.

Com isso, percebi que a psicologia ia se aproximando. É-me estranho pensar dessa forma, uma vez que poderíamos já "entender" previamente que a psicologia deveria estar presente para este público, para esta comunidade. Será que a psicologia conseguiria dar conta deste acontecimento? Se não é pelo acontecimento, por onde vai, então, a psicologia? Por onde poderia ser?

Percebi, com esta tese, que o grito trans tornou-se um pré-texto para denunciar as práticas violentas e perversas encontradas nas instituições de saúde e de educação. Tal pretexto 
diz respeito à necessidade de cuidar de nossa formação, de nosso fazer e de nossa clientela. Será que nós, psicólogos e psicólogas, revisitamos isso em nossas práticas? Será que conseguimos nos tornar textos traduzidos das histórias que recolhemos?

O grito que emana dos corpos trans e travestis vai ao encontro de nossa ação. Por que pensar o corpo? Para que pensar o corpo? As entrevistas reverberaram como o "canto da sereia" em busca de seu corpo polimorfo. Qual o corpo que quero/tenho? O corpo que posso ser ou o corpo que preciso/sou?

A mostração do corpo trans e travesti demarca-se pela sua presença. O corpo humano material/físico, por ter e ser matéria, já se mostra como fenômeno acontecido, o dizer de alguma coisa é uma figura humana. O corpo trans e travesti, assim, fica marcado pela sua "experiência de transição", porque não tem como se esconder do esperado dessa figura humana.

Percebo que as trajetórias de Fernanda, Joyce e Eduardo foram demarcadas pelo encontro com os similares, com rostos e corpos "conhecidos". O reconhecimento de si, pela presença do outro, é, talvez, um dos principais dilemas nas suas historiobiografias. Como ser mulher? Como ser homem? E o que eu sou em meio a tudo isso? Há, nesse sentido, uma apropriação de uma autoria. Existiria uma autoria que partiria da própria singularidade?

Entre "quem sou" ou "quem posso ser" habita o caráter do questionamento sobre o que, de fato, compreende o "meu lugar", "como me vejo". Perseguindo esse caminho, apesar de entender que o movimento social organizado de travestis, mulheres transexuais e homens trans é de e tem uma enorme contribuição nas trajetórias de vidas trans brasileiras, questiono os possíveis contrapontos em que os lugares, modos e formas que suscitam do movimento recaem como um "entrave" no modo como estas pessoas legitimam e veracizam suas experiências.

Qual a minha identidade? Como experiencio meu corpo? O que quero dizer com isso é: em que medida a comunidade plural do movimento não apagaria as singularidades que são dissidentes? Ou melhor, "como sou trans"? Aqui penso que se abre um prisma para pensarmos as concretudes do viver cotidiano de travestis, mulheres transexuais e homens trans, especialmente porque é a partir da experiência singular que se pode dizer quem se é.

A pluralidade do movimento, às vezes, parece fechar em dimensões e diagramações existentes pelo poder das relações. Esta pluralidade, criada oficiosamente, reverbera também o caráter da privação dos corpos, alocados a um texto de pretexto... Mas e minha singularidade? Como me vejo como trans/travesti?

Esses questionamentos surgem quando percebo que, durante as entrevistas, sou chamado a também pensar o cuidado dispensado sobre a própria existência. Ou seja, em que medida o meu corpo, enquanto meu e habitado por mim, é também zelado por mim? Em que 
sentido posso - mesmo que não tenha o aparato científico e profissional na concretização do corpo que posso e quero ser - autorizar-me e legitimar minhas ações com o meu corpo?

Bloqueando as ações, o espaço de se autorizar está, cada vez mais, longe de se tornar um corpo próprio, singular e plural ao mesmo tempo. Afinal, o meu corpo material é, mesmo que não circunscrito pela experiência que tenho do mesmo, o conjunto de paredes que pinto conforme minhas escolhas. Passo a compreender, seguindo essa perspectiva, que é possível poder-ser-sendo, algo que se aproximaria da dimensão de uma promoção de saúde, mesmo que haja entraves nos percalços do cotidiano vivido.

Pro-mover passa, assim, pelo sentido de mover-me em direção. Mobilizado(a) pelas diferenças concretas e existenciais, o sentido de promoção de saúde está interligado ao sentido de política. Só é possível, portanto, cuidar de si, do mundo e dos outros se, pela perspectiva de endereçamento, remeter-se ao destino - não no sentido de "ponto de chegada", mas no de debandar, sendo tocado(a) pelos relevos de sua história. As histórias precisam ser contadas. Elas são mais como letras, como contado em outro momento. As histórias se fazem no corpo, entre o corpo, para o corpo, com o corpo.

Embora o que se empreendeu acerca da saúde da população de travestis, mulheres transexuais e homens trans, nesta tese, tenha um sentido singular acossado a um diálogo com as políticas públicas em instituições - tendo a experiência do corpo como grito político, ético e estético - penso que é possível dizer e viver saúde a partir do modo como se destina a vida. Se entendemos que a política é marcada pelas relações humanas em pares ou em grupo, a garantia da saúde, enquanto uma promoção de cuidado que se faz via política, só aconteceria, nesse sentido, se mergulhada na experiência cotidiana compartilhada.

Esse pensamento caminha na direção de um ethos comunitário, dada a compreensão de humanidade via o sentido da vida que se empreende em comunidade, entre o que se torna comum, porém múltiplo, entre os humanos. Assim, penso que a compreensão de cuidado, que surge como apelo durante as entrevistas, perfaz-se pelo sentido de movimento, um cuidado que se aproximaria da condição de liberdade: é preciso cuidar de quem se é para quem se é. Como são? Para quem ou para o que são? O caráter da liberdade teria, portanto, uma noção que se voltaria muito mais ao cuidar de ser do que à liberdade de ser.

Como, então, a psicologia pode atentar-se a isso? De que modo seria possível construir uma psicologia que se debruçaria sobre a dimensão política do humano, anterior ao seu sofrimento? Aliás, o próprio sofrimento também não seria político? E nas trocas políticas entre humanos, também não estaria imbuída a própria possibilidade da impossibilidade? 
A partir disso, tendo como centro de debate as próprias historiobiografias testemunhadas, penso que o sentido de nossa ação clínica em psicologia, por mais que acossada à técnica moderna, deveria atentar-se ao singelo, à simplicidade, às miudezas da vida cotidiana. Entendo que esse movimento é o que possibilitaria uma menor distância entre nós, profissionais psicólogos(as), e nossa clientela, demarcando o questionamento deste mundo experienciado cotidianamente.

Desse modo, mesmo que direcionados(as) a responder a demandas deste mesmo mundo, ao modo da era da técnica e da tecnologia, especialmente no que diz respeito às expertises situacionais dos corpos travestis e trans, é possível resgatarmos o sentido originário grego, artesanal, tecido pelo fazer-saber de nossa ação. Se confirma, assim, algo exatamente feito: obra e ação caminhariam juntas, tal como o sentido originário da techné grega.

Fernanda, Joyce e Eduardo... Três pessoas com vidas, histórias e experiências diferentes, singulares, mas que se aproximam. Histórias cotidianas da vida mundana, da vida vivível, da vida (de)marcada. Corpos-existência, corpos-dobra, corpos-avessados.

Termino voltando à sala de casa, como quem espera uma visita tocar à porta, depois de uma viagem pelas “terras longínquas"... Tatuado, mestiçado, como humano que é, ex-istindo como é, cuidando de ser quem é para poder cuidar do ser de outros(as) mestiçados(as) existentes. Seria essa uma compreensão possível para uma ação psicológica clinicamente éticopolítica? Eis uma questão para a formação psi entre humanos... 


\section{REFERÊNCIAS}

Agamben, G. (2010). Homo Sacer: o poder soberano e a vida nua I (2a ed., H. Burigo, trad.). Belo Horizonte: Editora UFMG.

American Psychiatric Association. APA. (2014). Manual Diagnóstico e Estatístico de Transtornos Mentais: DSM-5 [recurso eletrônico] (5a ed.). Porto Alegre: Artmed.

Andrade, S. S. (2013). Mídia impressa e educação dos corpos femininos. In G. L. Louro, J. Felipe, \& S. V. Goellner (Orgs.), Corpo, Gênero e Sexualidade: um debate contemporâneo na educação (9a ed.) (pp. 109-123). Petrópolis, RJ: Vozes.

Araújo, J. B. (2016). Homossexualidade: a (des)construção do discurso do corpo. São Paulo: Fonte Editorial.

Arendt, H. (2008). Homens em tempos sombrios (D. Bottmann, trad.). São Paulo: Companhia das Letras.

Arendt, H. (2009). A promessa da política (2a ed., P. Jorgensen Jr., trad.). Rio de Janeiro: DIFEL.

Arendt, H. (2018a). A condição humana (13a ed. rev., R. Raposo, trad.). Rio de Janeiro: Forense Universitária.

Arendt, H. (2018b). Sobre a violência (9a ed., A. M. Duarte, trad.). Rio de Janeiro: Civilização Brasileira.

Assmann, S. J. (2013). Por uma política da vida a partir da relação entre corpo e vida. In A. B. Fraga, Y. M. Carvalho \& I. M. Gomes (Orgs.), As práticas corporais no campo da saúde (pp. 23-51). São Paulo: Hucitec.

Aun, H. A. (2005). Trágico Avesso no Mundo: Narrativas de uma prática psicológica numa instituição para adolescentes infratores. (Dissertação de Mestrado, Instituto de Psicologia, Universidade de São Paulo).

Barreto, C. L. B. T. (2013). Reflexões para pensar a ação clínica a partir do pensamento de Heidegger: da ontologia fundamental à questão da técnica. In C. L. B. T. Barreto, H. T. P. Morato \& M. T. Caldas (Orgs.), Prática Psicológica na Perspectiva Fenomenológica (pp. 27-50). Curitiba: Juruá.

Beluche, R. (2008). O corte da sexualidade: o ponto de viragem da psiquiatria brasileira no século XIX. São Paulo: Annablume.

Benjamim, W. (2012). Magia e técnica, arte e política: ensaios sobre literatura e história da cultura (S. P. Rouanet, trad., 8a ed. rev.). São Paulo: Brasiliense. 
Bento, B. (2006). A reinvenção do corpo: sexualidade e gênero na experiência transexual. Rio de Janeiro: Garamond.

Bento, B. (2011). Apresentação. In J. Leite Jr., Nossos corpos também mudam: a invenção das categorias "travesti" e "transexual" no discurso científico (pp. 15-22). São Paulo: Annablume, FAPESP.

Bento, B. (2017a).Transviad@s: gênero, sexualidade e direitos humanos. Salvador: EDUFBA.

Bento, B. (2017b). A reinvenção do corpo: sexualidade e gênero na experiência transexual (3a ed.). Salvador, BA: Editora Devires.

Braga, T. B. M., Ferreira, B. L., Takeshita, M. H., \& Delavia, F. C. (2013). Solicitude como modo de cuidar: atenção psicológica como cartografia clínica e plantão psicológico em hospital geral. In C. L. B. T. Barreto, H. T. P. Morato \& M. T. Caldas (Orgs.), Prática Psicológica na Perspectiva Fenomenológica (pp. 283-315). Curitiba: Juruá.

Brasil. Ministério da Saúde. (2015). Transexualidade e Travestilidade na saúde. Brasília: Ministério da Saúde.

Britzman, D. (2015). Curiosidade, sexualidade e currículo. In G. L. Louro (Org.), O corpo educado: pedagogias da sexualidade (3a ed., pp. 83-111). Belo Horizonte: Editora Autêntica.

Butler, J. (2002). Como os corpos se tornaram matéria: entrevista com Judith Butler. Estudos Feministas, 10(1), 155-167.

Butler, J. (2009). Desdiagnosticando o gênero (A. Rios, trad., M. Arán, rev.). Physis Revista de Saúde Coletiva, 19(1), 95-126.

Butler, J. (2015). Problemas de gênero: Feminismo e subversão da identidade (8a ed.). Rio de Janeiro: Civilização Brasileira.

Butler, J. (2016). Quadros de guerra: Quando a vida é passível de luto? (2a ed., S. T. N. Lamarão \& A. M. da Cunha, trad.). Rio de Janeiro: Civilização Brasileira.

Butler, J. (2017). Relatar a si mesmo: Crítica da violência ética (1a ed., R. Bettoni, trad.). Belo Horizonte: Autêntica Editora.

Cabral, B. E., \& Morato, H. T. P. (2013). A questão de pesquisa como bússola: notas sobre o processo de produção de conhecimento em uma perspectiva fenomenológica existencial. In C. L. B. T. Barreto, H. T. P. Morato \& M. T. Caldas (Orgs.), Prática Psicológica na Perspectiva Fenomenológica (pp. 159-182). Curitiba: Juruá.

Carvalho, B. R. B. (2014). “Tá pensando que travesti é bagunça?” Repertórios sobre travestilidade, em contexto de criminalidade, por jornais de Pernambuco. (Dissertação de 
Mestrado, Programa de Pós Graduação em Psicologia, Universidade Federal de Pernambuco).

Chauí, M. (2018). Sobre a violência (1a ed.). Belo Horizonte: Autêntica Editora.

Concilio, I. L., Amaral, M., \& Silveira, P. M. (Orgs.). (2017). Transcidadania: Práticas e trajetórias de um programa transformador. São Paulo: Koinonia.

Critelli, D. M. (1996). Analítica do sentido: uma aproximação e interpretação do real de orientação fenomenológica. São Paulo: EDUC/Brasiliense.

Critelli, D. M. (2012). História pessoal e sentido da vida: historiobiografia. São Paulo: EDUC/FAPESP.

DATASUS. (2008). Classificação Estatística Internacional de Doenças e Problemas Relacionados à Saúde - CID 10 [versão online]. Recuperado de http://www.datasus.gov.br/cid10/V2008/cid10.htm.

Decreto n. 8.727. (2016, 28 de abril). Dispõe sobre o uso do nome social e o reconhecimento da identidade de gênero de pessoas travestis e transexuais no âmbito da administração pública federal direta, autárquica e funcional. Brasília, DF: Presidência da República. Recuperado de http://www.planalto.gov.br/ccivil_03/_ato20152018/2016/decreto/D8727.htm.

Deleuze, G., \& Guattari, F. (2011). Mil Platôs: capitalismo e esquizofrenia 2 (Vol. 2, 2a ed., A. L. Oliveira \& L. C. Leão, trad.). (Coleção TRANS). São Paulo: Editora 34. (Obra original publicada em 1980).

Duarte, A. (2010). Vidas em risco: crítica do presente em Heidegger, Arendt e Foucault. Rio de Janeiro: Forense Universitária.

Figueiredo, L. C. M. (2014). Matrizes do pensamento psicológico (20a ed.). Petrópolis, RJ: Vozes.

Flick, C. (2009). Introdução à Pesquisa Qualitativa. São Paulo: Artmed.

Foucault, M. (2000). Microfisica do poder (15a ed.). Rio de Janeiro: Graal.

Foucault, M. (2017). História da sexualidade: A vontade de saber (5a ed., M. T. C. Albuquerque \& J. A. G. Albuquerque, trad.). (Coleção Biblioteca de Filosofia). São Paulo: Paz e Terra.

Fraga, A. B., Carvalho, Y. M. \& Gomes, I. M. (Orgs.). (2013). As práticas corporais no campo da saúde. São Paulo: Hucitec.

Francisco, A. L. (2012). Psicologia clínica: prática em construção e desafios para a formação. Curitiba, PR: CRV. 
Gadamer, H. G. (2011). O caráter oculto da saúde (2a ed., A. L. Costa, trad.). Petrópolis, RJ: Vozes.

Galli, R. A., \& Vieira, E. M. (2013). Corpos mutantes, mulheres intrigantes: Transexualidade e cirurgia de redesignação sexual. Psicologia: Teoria e Pesquisa, 29(4), 447-457.

Heidegger, M. (1959). Serenidade. Lisboa: Instituto Piaget.

Heidegger, M. (2009). Seminários de Zollikon (G. Arnhold, M. F. A. Prado \& R. Kirchner, trad.). Petrópolis/RJ: Vozes; Bragança Paulista/SP; Editora Universitária São Francisco.

Heidegger, M. (2011). A caminho da linguagem (5a ed.). Petrópolis/RJ: Vozes; Bragança Paulista /SP; Editora Universitária São Francisco.

Heidegger, M. (2012). Ser e tempo (7a ed.). Petrópolis: Vozes.

Jaspers, K. (1991). Il medico nell'età della técnica. Milano: Raffaello Cortina Ed.

Josgrilberg, F. P. (2013). Possibilidades de compreensão do corporar, a partir da analítica do ser-aí: outra leitura para a atenção psicológica (Tese de Doutorado, Instituto de Psicologia, Universidade de São Paulo).

Kohn, J. (2009). Introdução. In H. Arendt, A promessa da política (2a ed., P. Jorgensen Jr., trad.). Rio de Janeiro: DIFEL.

Larrosa, J. (2018). Tremores: escritos sobre a experiência (1a ed., C. Antunes \& J. W. Geraldi, trad.). Belo Horizonte: Autêntica Editora.

Leite Jr., J. (2011). Nossos corpos também mudam: a invenção das categorias "travesti" $e$ "transexual” no discurso científico. São Paulo: Annablume, FAPESP.

Louro, G. L. (2007). Um corpo estranho: Ensaios sobre sexualidade e teoria queer. Belo Horizonte: Autêntica Editora.

Louro, G. L. (2015). O corpo educado: pedagogias da sexualidade (3a ed., T. T. Silva, trad.). Belo Horizonte: Autêntica Editora.

Maciel, E. (2014). Aspectos epistemológicos e éticos da pesquisa clínica. In A. N. Souza \& Pitanguy, Saúde, corpo e sociedade (2a ed., pp. 67-84). Rio de Janeiro: Editora UFRJ.

Maldonato, M. (2014). A subversão do ser: identidade, mundo, tempo, espaço: fenomenologia de uma mutação (2a ed., R. Barni, L. Loprete, trad.). São Paulo: Edições Sesc São Paulo.

Melo, J. B. (2015). O corpo que habito: possibilidades de compreensão para a experiência do corpo amputado (Dissertação de Mestrado, Programa de Pós Graduação em Psicologia Clínica, Universidade Católica de Pernambuco). 
Michaellis. (2018). Dicionário Brasileiro da Língua Portuguesa [recurso eletrônico]. São Paulo: Editora Melhoramentos. Recuperado de https://michaelis.uol.com.br/modernoportugues/

Minayo, M. C. S. (Org.). (2002). Pesquisa social: teoria, método e criatividade (20a ed). Petrópolis, RJ: Vozes.

Miskolci, R. (2013). Teoria Queer: um aprendizado pelas diferenças (2a ed). Belo Horizonte: Autêntica Editora: UFOP.

Morato, H. T. P. (2018). Reflexões acerca da saúde: implicações para o desassossego humano contemporâneo. In E. Dutra. (Org.). O desassossego humano na contemporaneidade (pp. 167-197). Rio de Janeiro: Via Verita.

Oliva, A. (2014). Cabe ainda invocar o método científico universal? In A. N. Souza, \& J. Pitanguy, Saúde, corpo e sociedade (2a ed., pp. 21-52). Rio de Janeiro: Editora UFRJ.

Oliveira, M. J. (2014). Uma etnografia sobre o atendimento psicoterapêutico a transexuais. Estudos Feministas, 22( 3), pp. 839-862.

Ortega, F., \& Zorzanelli, R. (2010). Corpo em evidência: a ciência e a redefinição do humano. (Coleção Contemporânea). Rio de Janeiro: Civilização Brasileira.

Pelúcio, L. (2009). Abjeção e desejo: uma etnografia travesti sobre o modelo preventivo de aids. São Paulo: Annablume, Fapesp.

Portaria n.1.820. (2009, 13 de agosto). Dispõe sobre os direitos e deveres dos usuários da saúde. Brasília, DF: Presidência da República. Recuperado de http://bvsms.saude.gov.br/bvs/saudelegis/gm/2009/prt1820_13 08 2009.html.

Portaria $n^{\circ}$ 1.707. (2008, 18 de agosto). Institui no âmbito do Sistema Único de Saúde (SUS) o Processo Transexualizador, a ser implantado nas unidades federadas, respeitadas as competências das três esferas de gestão. Brasília, DF: Ministério da Saúde. Recuperado de http://bvsms.saude.gov.br/bvs/saudelegis/gm/2008/prt1707_18_08_2008.html

Portaria $n^{o}$ 2.803. (2013, 19 de novembro). Redefine e amplia o Processo Transexualizador no Sistema Único de Saúde (SUS). Brasília, DF: Ministério da Saúde. Recuperado de http://bvsms.saude.gov.br/bvs/saudelegis/gm/2013/prt2803_19_11_2013.html

Portaria $n^{\circ}$ 2.836. (2011, 1 de dezembro). Institui no âmbito do Sistema Único de Saúde (SUS), a Política Nacional de Saúde Integral de Lésbicas, Gays, Bissexuais, Travestis e Transexuais (Política Nacional de Saúde Integral LGBT). Brasília, DF: Ministério da Saúde. Recuperado de http://bvsms.saude.gov.br/bvs/saudelegis/gm/2011/prt2836_01_12_2011.html

Portaria $n^{\circ}$ 457. (2008, 19 de agosto). Define as Diretrizes Nacionais para o Processo Transexualizador no Sistema Único de Saúde. Brasília, DF: Ministério da Saúde. 
Recuperado de http://bvsms.saude.gov.br/bvs/saudelegis/sas/2008/prt0457_19_08_ 2008.html

Resolução CFP n. 17/2002. (2002, 19 de dezembro). Fica instituído o Manual de Elaboração de Documentos, produzidos por psicólogos, decorrentes de avaliações psicológicas. Brasília: Conselho Federal de Psicologia. Recuperado de https://site.cfp.org.br/wpcontent/uploads/2002/12/resolucao2002_17.PDF

Resolução CFP n.007/2003. (2003, 14 de junho). Institui o Manual de Elaboração de Documentos Escritos produzidos pelo psicólogo, decorrentes de avaliação psicológica e revoga a Resolução CFP n.17/2002. Brasília: Conselho Federal de Psicologia. Recuperado de https://site.cfp.org.br/wp-content/uploads/2003/06/resolucao2003_7.pdf

Santos, S. E. B. (2005). A experiência de ser ex-esposa: uma oficina sociopsicodramática como intervenção para problematizar a ação clínica (Dissertação de Mestrado, Programa de Pós Graduação em Psicologia Clínica, Universidade Católica de Pernambuco).

Santos, S. E. B. (2016). “Olha!... arru(a)ção!?...” a ação clínica no viver cotidiano: conversação com a Fenomenologia Existencial (Tese de Doutorado, Programa de Pós Graduação em Psicologia Clínica, Universidade Católica de Pernambuco).

Serres, M. (1993). Filosofia Mestiça. Rio de Janeiro: Nova fronteira.

Silva, E. F. G. \& Santos, S. E. B. (2017). Fenomenologia Existencial como caminho para pesquisa qualitativa em psicologia. Revista Nufen: Phenom. Interd. 9(3), 110-126.

Simpson, K. (2015). Transexualidade e travestilidade na saúde. In: Brasil. Ministério da Saúde, Transexualidade e Travestilidade na Saúde (pp. 9-16). Brasília: Ministério da Saúde.

Sohn, A. M. (2011). O corpo sexuado. In A. Corbin, J. J. Courtine \& G. Vigarello, História do corpo: As mutações do olhar - o século XX (4a ed., pp.109-154). Petrópolis, RJ: Vozes.

Souza, A. N. (2014). A pesquisa qualitativa em saúde. In A. N. Souza \& J. Pitanguy, Saúde, corpo e sociedade (2a ed., pp. 85-99). Rio de Janeiro: Editora UFRJ.

Thiollent, M. (1986). Metodologia da Pesquisa-ação. São Paulo: Cortez.

Ventura, M. (2010). A transexualidade no tribunal: saúde e cidadania. Rio de Janeiro: EdUERJ.

Vidale, G. (2017). Meu filho é trans. Veja (edição 2552, out. 2017) [versão online]. São Paulo: Editora Abril. Recuperado de https://veja.abril.com.br/edicoes-veja/2552/

Vigarello, G. (2006). História da beleza. Rio de Janeiro: Ediouro.

Weeks, J. (2015). O corpo e a sexualidade. In G. L. Louro (Org.). O corpo educado: pedagogias da sexualidade (3a ed., pp. 35-81). Belo Horizonte: Editora Autêntica. 
APÊNDICE 


\title{
TERMO DE CONSENTIMENTO LIVRE E ESCLARECIDO (TCLE)
}

\author{
No de registo no CEP-IPUSP: 79045917.1.0000.5561
}

Prezado Sr.(a),

Este Termo de Consentimento pode conter palavras que você não entenda. Se for o caso, peça explicações e esclarecimentos. Você assinará duas vias iguais, ficando uma com você e outra com o pesquisador responsável.

Você está sendo convidado(a) a participar de uma pesquisa, intitulada " Casa sem chão, casa sem teto': o corpo trans em questão nos serviços de saúde", que objetiva compreender como profissionais que lidam com a população trans no processo transexualizador endereçam suas práticas de cuidado em torno desta população. Sua participação não é obrigatória e é voluntária. Você tem o direito de não querer participar ou de sair desta pesquisa a qualquer momento. Você também pode ser desligado(a) do estudo a qualquer momento sem o seu consentimento nas seguintes situações: (a) você sofra efeitos indesejáveis não esperados; (b) o estudo termine. Em caso de você decidir retirar-se do estudo, favor notificar o profissional e/ou pesquisador que esteja atendendo-o(a).

A colaboração será a participação em entrevistas individuais ou encontros de grupo, que serão realizadas no Laboratório de Estudos em Fenomenologia Existencial e Prática em Psicologia do Instituto de Psicologia da Universidade de São Paulo (LEFE-IPUSP) - o endereço está disposto abaixo - e serão gravadas em áudio, que ficarão sob guarda apenas do pesquisador durante um prazo de 5 (cinco) anos após o estudo, com a finalidade de transcrições para análises posteriores ao nosso encontro.

Espera-se que, como resultado deste estudo, você possa entrar em contato com sua experiência e testemunhar a realidade do cotidiano de travestis, mulheres e homens trans. As orientações e/ou informações narradas podem servir como medidas de promoção à saúde, bem como diminuir danos no cotidiano da população $\mathrm{T}$.

Se você sofrer efeitos indesejáveis (como, por exemplo, não se sentir confortável para responder alguma pergunta; emocionar-se e/ou sentir-se mal pelo depoimento dado) como resultado direto da sua participação nesta pesquisa, a necessária assistência profissional será providenciada pelo próprio pesquisador ou pelo LEFE-IPUSP.

Ademais, o pesquisador responsável pela pesquisa deverá fornecer qualquer esclarecimento, assim como tirar dúvidas, bastando contato: Contato do Pesquisador: Jailton Bezerra Melo. Tel: (11) 99642-1221. E-mail: melo.jailtonb@gmail.com. Contato do Laboratório (LEFE-IPUSP): Profa. Dra. Henriette T. P. Morato (Docente responsável pelo laboratório). Av. Professor Mello de Moraes, 1721, Bloco D - Sala 229, CEP 0558-900, Cidade 
Universitária - São Paulo/SP. Tel: (11)3091-4285. E-mail: lefe@usp.br. Contato do Comitê de Ética em Pesquisa com Seres Humanos do Instituto de Psicologia da Universidade de São Paulo (CEPH-IPUSP): Endereço: Av. Prof. Mello Moraes, 1.721 - Bloco G, $2^{\circ}$ andar, sala 27, CEP 05508-030, Cidade Universitária - São Paulo/SP. Tel: (11) 3091-4182. E-mail: ceph.ip@usp.br.

A sua identidade e os dados de seu trabalho serão mantidos em sigilo. Os resultados serão sempre apresentados como o retrato das práticas de cuidado de profissionais de saúde à população T. Dessa forma, você não será identificado(a) quando o material de seu registro for utilizado, seja para propósitos de publicação científica ou educativa

Você não terá nenhum gasto com a sua participação no estudo e também não receberá pagamento pelo mesmo. Caso, eventualmente, haja gasto com sua participação, você será ressarcido(a) ou reparado(a) a algum dano decorrente de sua participação. 


\title{
DECLARAÇÃO DE CONSENTIMENTO
}

$\mathrm{Eu}$ , RG

declaro que li ou alguém leu para mim as informações contidas neste documento antes de assinar este Termo de Consentimento. Declaro que todo o procedimento utilizado na descrição de estudo de pesquisa “'Casa sem chão, casa sem teto': o corpo trans em questão nos serviços de saúde" foi satisfatoriamente explicado e que recebi respostas para todas as minhas dúvidas. Confirmo também que recebi uma via de igual teor e igualmente assinada deste Termo de Consentimento Livre e Esclarecido. Compreendo que sou livre para me retirar do estudo em qualquer momento, sem perda de benefícios ou qualquer outra penalidade e que serei ressarcido caso haja algum custo imprevisto ou dano relacionado à pesquisa.

Dou meu consentimento de livre e espontânea vontade para participar desta pesquisa.

Este estudo foi aprovado pelo Comitê de Ética em Pesquisa com Seres Humanos do Instituto de Psicologia da Universidade de São Paulo (CEPH-IPUSP). Endereço: Av. Prof. Mello Moraes, 1.721 - Bloco G, $2^{\circ}$ andar, sala 27 - CEP 05508-030 - Cidade Universitária - São Paulo/SP. E-mail: ceph.ip@usp.br Telefone: (11) 3091-4182

Assinatura do Declarante

\section{DECLARAÇÃO DO PESQUISADOR}

DECLARO, para fins de realização de pesquisa, ter elaborado este Termo de Consentimento Livre e Esclarecido (TCLE), cumprindo todas as exigências contidas nas alíneas acima elencadas e que obtive, de forma apropriada e voluntária, o consentimento livre e esclarecido do declarante acima qualificado para a realização desta pesquisa.

São Paulo, de de 201

\author{
Jailton Bezerra Melo \\ CRP: 06/132537 \\ (Pesquisador)
}




\section{ANEXOS}




\section{NOTAS SOBRE O TEXTO: POR UM OUTRO OLHAR}

Profa. Dra. Suely Emilia de Barros Santos

Tese de Doutorado: “Afasta de mim esse CALE-SE”: narrativas de corporalidades travestis e trans para uma ação clínica e política em psicologia, de Jailton Bezerra Melo.

Iniciarei agradecendo o convite de Jailton e de sua orientadora, Profa. Dra. Henriette Morato. Estar nesta banca tem para mim um sentido bem especial. É um reencontro com um orientando de graduação por quem tenho uma grande admiração pela trajetória trilhada academicamente, profissionalmente, tendo se tornado, além disso, um amigo querido; um reencontro com minha orientador(a)miga de mestrado e doutorado, que tem um lugar afetivo e de importância impar para mim; um reencontro e encontro com amigas e profissionais que me sinto honrada em compartilhar desse momento. Sem dúvida é uma grande satisfação ser presença nesse momento ao lado de vocês.

Passo agora a me dirigir a Jai. Você deu um salto significativo da banca de qualificação para a defesa e vi contemplado os pontos que dialogamos durante o momento prévio a este. Mas, pelo crescimento que você imprimiu a sua tese, surgiram outras reflexões e, assim, espero que, neste momento, a gente empreenda uma conversação a partir deste trabalho de Tese.

Confesso que fui impacta por sua tese desde a capa. O título, a criatividade exposta no sumário (que me instigou a prosseguir). Ao terminar de ler sua tese, dei um suspiro: Ufa! Cansaço? Não. Eu estava tomada por histórias que me atravessaram, me desalojaram e me provocaram. E eu não sabia o que dizer. Lembrei da música "Gentileza", de Marisa Monte: “Apagaram tudo. Pintaram tudo de cinza”. Sem dúvida não lembrei à toa. Afinal, você sinalizou a presença do cinza em sua tese, como algo que a ciência não consegue captar (p.16). Mas... "Merecemos ler as letras / E as palavras..." e aí me ponho a contar sobre a minha leitura, mesmo que sem linearidade, ou até mesmo sem os dogmas da ciência.

Na pág. 13 você põe uma provocação que lhe acompanha desde a sua dissertação: Será que a Psicologia não teria uma dívida com as questões do corpo? Penso que sua andança como pesquisador se mostra como caminhos que, para além de questionar essa dívida, apontam e propõem possibilidades não de pagar a dívida - pois creio que ela ainda se faz presente -, mas de chamar psicólogos/as a pensarem sobre o "cor-pôr-ar", como você nomeia. 
Aqui lembro de Sergio Perazzo, um psiquiatra/psicodramatista, que em seu livro "Descansem em paz os nossos mortos dentro de mim", assinala que a medicina, ao invés de iniciar o curso pelo estudo da anatomia de "corpos" mortos, deveria iniciar numa sala de nascimento - um acontecimento. Será que está no olhar para o corpo como "meu corpo", uma possibilidade de a Psicologia instaurar uma outra caminhada, em que o psicologismo e as premissas teoréticas e tecnicistas não estejam a priori do humano? Afinal, como você afirma, o corpo é "um arsenal pelo qual a vida acontece e o humano se conhece" (p.55).

Em sua metodologia, a narrativa me salta aos olhos e fico radiante quando você assinala a relação com a literatura de cordel. Uma literatura que traz a marca da nordestinês que nós temos e que no modo de cantar/contar histórias se mostra como o corpo em conversação fazendo todo o sentido a sua afirmativa na página 30 , de que "toda a tese, em si, torna-se um diário de bordo desta imersão experienciada".

Embora você não tenha sinalizado, compreendo que sua pesquisa se fez cartográfica (até pelas flutuações da sua questão-bússola). Isso demarca que você foi/é um viajante/turista durante todos esses anos em que se pôs a criá-la, e ela se mostra como um acontecimento, como algo que suscita desdobramentos (Deleuze) ou funda mundos (Figueiredo).

Pensar que a "elevação da escolaridade", "a retificação do registro civil" como disse Fernanda (p. 47), é um acontecimento na vida de uma pessoa trans, causa um misto de sentimento. $\mathrm{O}$ sentido desses acontecimentos em cada existência é possibilidade de abertura para um reconhecimento que não temos a dimensão dos desdobramentos.

Lembro de um livro infanto-juvenil: "Eu e Mim Mesmo", de Flávio de Souza, onde o autor escreve:

\footnotetext{
Era uma vez Eu. Eu era um menino que chamava Luís. Minha mãe pensava que eu me chamava Luís Fernando, só porque ela escolheu este nome no dia em que eu nasci e mandou pôr naquele papel que todo mundo tem provando que existe. Chama Certidão de Nascimento, eu sei porque eu perguntei. Eu acho uma bobagem existir isso, porque, se uma pessoa tem de mostrar um papel para provar que nasceu, é porque essa pessoa é invisível. Se a pessoa não é invisível, pra que o papel? É só olhar pra ver, não? Mas deixa prá lá a certidão. O importante desta história é que eu chamava Luís, só Luís, apesar de lá estar escrito Luís Fernando.
}

Esse nome que nos veste, reveste, traveste, transverte... nos coloca diante de um outro que muitas vezes não nos conhece/reconhece. O Arlequim precisa ir se despindo e sua pelecorpo tatuado contam narrativas de experiências.

Pegando a metáfora com que você trabalha do casaco de Arlequim, lembrei de duas músicas: a primeira "Com que roupa" de Noel Rosa, e a segunda, "Velha roupa colorida" de Belchior: "Agora vou mudar minha conduta, / Eu vou pra luta pois eu quero me aprumar / [...] 
Pois esta vida não está sopa e eu pergunto: com que roupa? / Com que roupa eu vou pro samba que você me convidou?" e, "No presente, a mente, o corpo é diferente / E o passado é uma roupa que não nos serve mais". Essas músicas me remetem a uma frase de uma mulher quilombola, num evento que participei na Fazenda Florestan Fernandes do MST: "Todo dia eu saio da minha casa e visto esta pele para a guerra". Lembro das palavras de Eduardo, "eu saio já esperando as análises” (p.97). Para mim, é dessa guerra que você fala. É a minha pele-corpo, a sua pele-corpo, a pele-corpo de todos/as aqui e, assim, vestimo-nos de nós mesmos/as dia a dia para a guerra do cuidar de existir.

Sigamos então, resistindo à colonização do saber, que tenta patologizar as nossas peles. E aqui falo da do DSM-V, da CID-11, do poder médico e judiciário, dos laudos/relatórios e pareceres emitidos pelos/as psicólogos/as, como você tão bem discorreu, e que Eduardo aponta que se afasta do que ele espera/demanda dos/as profissionais: "Eu acho que os profissionais têm que estar aqui pra ajudar a gente na questão do Viver" (p. 108). Lembro aqui o que ouvi uma vez de Nino (grafiteiro e DJ do 3 Soma, grupo de Hip Hop em Caruaru/PE), referindo-se ao papel da psicologia, e que escrevi na minha tese, mesmo que não dirigida a população T: “É que ela não tá doente! Ela tá sofrendo com o que passa na cabeça dela! Então não é pra curar, é pra ela se abrir... pra viver bem!” [...] “A Psicologia é para viver bem!”. (p. 71). Pergunto: como os psicólogos/as podem agir para se inclinarem para o viver? Como você assinalou (p.16): "Tem dor que dói no corpo que não tem olho que enxergue".

Quero dizer-lhe que lendo seu trabalho fui tocada várias vezes pela emoção, pela inquietação, pela provocação, pela fluidez do texto, pelo calor de histórias vivas marcadas pelo "Sofrimento de poder-ser" ou como você mesmo falou, "Ser a pessoa 'que se quer ser"” (p. 52), fenômeno pulsante em sua tese. E, justamente por pulsar, pois “ $O$ pulso ainda pulsa" (Titãs), nasce uma beleza em meio ao que muitas vezes é desprezível, feio, dolorido... como "a violação do direito de existir sendo quem se é" (p.130), a beleza de uma discussão acadêmica fundamentada, atravessada por contações de histórias.

Pelas páginas da tese me encontrei com várias histórias compartilhadas com você e outras que me atravessam também como pesquisadora, mulher negra, professora, psicóloga, como por exemplo quando você fala da burocracia como dificultadora e até impedidora de poder ser quem se quer ser. Você pergunta: "Quem eu posso ser, quando me deparo com a burocracia para autorizar minha existência?”. Essa burocracia chamada de certidão de nascimento/casamento/divórcio que o "Luís" da história questiona, que eu questionei na minha dissertação sobre a experiência de ser ex-esposa, que você questiona quando a população $\mathrm{T}$ 
chega aos dispositivos de saúde, e nas escolas. A constatação que não há evasão da população T e sim expulsão das escolas (p.59), é uma contribuição que você traz para a área de Educação.

Além disso, pensando o diálogo saúde educação, vejo como pertinente a sua crítica/proposta de que não é "necessária uma disciplina específica que 'normatize' a questão de gênero e sexualidade na academia, mas que priorize o ensino em educação e saúde como sendo uma prática por si só interventiva, contemplando-os como parte do existir humano" (p. 96). Nessa proposta você dá a essas questões de gênero e sexualidade um lugar para além do conteúdo, mas de propriedade no existir humano e que merece atenção e cuidado da educação e da saúde.

Focando na dor de existir, você me provoca a olhar para o desafio que nós, psicólogos/as e trabalhadores/as da saúde precisamos cuidar e defender, que é não tamponar o sofrimento e, em especial, gritar que é inaceitável a tentativa da sedação da dor, já que dor e sofrimento são tonalidades afetivas próprias do existir humano. Corramos da "patologização" dos nossos modos de ser à custa da massificação cisheteronormativa, binária. Corramos da armadilha do diagnóstico. Corramos do olhar para a saúde como adequação, como você sinaliza e que Joyce narrou "Os médicos me botaram na sala de homem. [...] TODOS OS MÉDICOS QUE CHEGAVAM, PRA MIM, QUE ME OLHAVAM... [...] Tipo assim, olhava pra mim e 'Enfermeira!', e aí a enfermeira ia e 'Não, é ele mesmo!'”. Me parece que a prática profissional nessa perspectiva discursiva, alia-se à violência e afasta a população T do SUS, em especial das UBSs e das instituições de educação.

Um aspecto que me instiga e que estou totalmente tatuada, é a proposta de pensar a ação clínica como ação política, voltada para "o que se compreende por existência sem desvinculála ao viver cotidiano" (p.120), que está totalmente em interface com a política, "a qual é a base para os 'acordos humanos' serem realizados e destinados”' (p.134). Esse viver cotidiano solicita uma ação clínica que hermeneuticamente se constrói na ação política entre humanos, em direção a acordos con-sentidos - a presença viva da coparticipação. Parece-me ser esse um aspecto que demanda atenção da psicologia e você se debruça sobre ele, pois você se inclina em comunhão, a recolher histórias do cotidiano dos/as viventes dessa tese.

Pegando seu (g)rito de passagem no trânsito entre "quem sou antes de entrar no mar" e "quem sou após imergir sem saber nadar num oceano aberto" (p. 164), gostaria de lhe escutar sobre esse gritar.

Como quebrar esse diálogo arraigado com a patologização das existências, apregoado pela psicologia? A sua proposta de "considerarmos homens, mulheres e travestis [e transexuais] como condições da existência humana" realça a despatologização das generidades. Será que 
essa proposta também pode contribuir para esse fenômeno social/político/existencial que tanto me inquieta - o fenômeno da exclusão? Há exclusão ou há uma inclusão precária, instável e marginal, ou ainda uma contradição, como diz Martins em seu livro "Exclusão social e a nova desigualdade"? Como tornar-se humano para outros/as, sendo considerada/olhada como bando, banidas da tessitura dos acordos de convivência pública, entre humanos? Como habitar essa "arena" - espaço público que quer ser reconhecido como espaço da civilidade humana, quando o meu lugar é sem lugar? Como conviver com o que vejo/olho como indizível?

Volto-me mais uma vez para sua proposta de "uma clínica que tenha a tensão nas injustiças sociais e, portanto, política” (p. 197-198). E aqui não podia deixar de aparecer as questões da natalidade, da pluralidade, como assinala Arendt. A tarefa de existir-com-outros é muitas vezes inóspita, estranha, provoca dor/sofrimento. Aqui fiquei pensando: afastando de cada um de nós a ideia de doença e aproximando do olhar de que ainda é sofrimento poder-sercom-outros quem se é, será que ao deparar-se com tamanha violência, a população T encontrase trans-tornada?

Mas parece que, como assinalado na letra de Hölderlin, citada pelo Heidegger, "Mas, onde há perigo, cresce também a salvação", aí, também reside a possibilidade de algo se dar a ver no transtorno vivido. Trans Torno, Torno Trans. Eis a expressão pulsante de que me torno diverso/a, tenho múltiplas peles, trans-porto múltiplas peles que são minhas. Será essa a inquietação que muitas vezes nos cega e nos impede de olharmos a população $\mathrm{T}$ que sofre cotidianamente?

Confesso que agora estou emocionada. Meu corpo pulsa, vibra e lhe agradeço Jai, pois seu trabalho me abriu a possibilidade de um outro olhar. Sejamos escutadores/as no viver cotidiano de peles/corpos que pulsam. Penso que aqui pode ser uma proposta interventiva desencoberta no seu trabalho - a ação clínica imbricada na política pulsa criação. Ela está “amparada nas acontecências das experiências vividas no cotidiano político" (p. 202).

Seu trabalho é provocativo e desafiador, pois você se dispôs corajosamente a não ser "reprodutor de ideias e sim compositor". Poderia dizer muito mais sobre o seu trabalho. Mas... escolhi parar por aqui, empolgada em compreender que ser travesti, ser mulher transexual, ser homem trans se mostra como um modo de existir no mundo com outros, ao mesmo tempo que se faz modo de resistir sendo trânsito. Existir/resistir sendo trânsito nos amedronta? Não captamos o cinza? Se faz mistério?

Para concluir, retorno a um trecho da minha conversação com você na banca de qualificação: Esperando ter contribuído de alguma forma com seu trabalho, realço que no cenário político atual do nosso País, sua Tese reveste-se de importância ímpar. E isto foi 
sinalizado várias vezes por você, o que anuncia e afirma a ação clínica coexistindo com a ação ético-política e estética do seu trabalho. Avante companheiro! Este é mais um grito na luta pela cidadania, pelo viver digno, pelo direito a sermos quem quisermos ser! É uma denúncia a violência que silencia, alimenta ódio, preconceito, transfobia, massacra corpos - eu, você, brasileiros/brasileiras, nordestinos/nordestinas, gente como a gente, gente como outros e outras, especialmente e em letras garrafais A POPULAÇÃO T. Muito Tesão para denunciar que TeSÃO, SÃOTe(s) que existem sim de modo singular, e seus corpos são expressão de que TeSÃO e tesão reverberam em cada um/a de nós. Afinal, a diferença integra a unidade de gênero (somos humanos). Mas há diferenças, singularidades. Pensar a diferença sem quebrar a unidade (“Ninguém solta a mão de ninguém”). Seria a expressão da riqueza, a expressão da própria unidade.

Nós, que nos vestimos com trans-tornos que expressam nossa dor de existir, contamos com a sua presença como profissional comprometido com a ação clínica imbricada com ação política. Prossiga, Cabra Macho! - expressão usada em nossa terra, o Nordeste, mas que geralmente ninguém se dá conta de que cabra não é bode, mas é macho.

Suely Emilia

24/10/2019 


\section{USP- INSTITUTO DE \\ PSICOLOGIA DA \\ UNIVERSIDADE DE SÃO}

\section{PARECER CONSUBSTANCIADO DO CEP}

\section{DADOS DO PROJETO DE PESQUISA}

Título da Pesquisa: "Casa sem chão, casa sem teto": o corpo trans em questão nos serviços de saúde.

Pesquisador: Jailton Bezerra Melo

Área Temática:

Versão: 2

CAAE: 79045917.1 .0000 .5561

Instituição Proponente: UNIVERSIDADE DE SAO PAULO

Patrocinador Principal: FUND COORD DE APERFEICOAMENTO DE PESSOAL DE NIVEL SUP

\section{DADOS DO PARECER}

Número do Parecer: 2.431 .233

\section{Apresentação do Projeto:}

Trata-se de projeto de Doutorado orientado pela Professora Henriette Tognetti Penha Morato. O projeto propõe-se a compreender como profissionais que lidam com a população trans no processo transexualizador endereçam suas práticas de cuidado em torno desta população para, daí, abrir possibilidades outras de construção de uma clínica que se debruce a questões contemporâneas que atravessam as diversas práticas e saberes.

Trata-se de uma pesquisa qualitativa numa perspectiva fenomenológica existencial, que visa compreender estas práticas de cuidado e possibilidades de intervenção. Nesta perspectiva, a própria pesquisa revela-se como interventiva, por dialogar com atores institucionais que vivenciam o cotidiano de atenção e cuidado à população trans.

\section{Objetivo da Pesquisa:}

De acordo com o pesquisador, os objetivos são os seguintes:

Objetivo Primário:

Compreender como profissionais que lidam com a população trans no processo transexualizador endereçam suas práticas de cuidado em torno do corpo trans.

Objetivo Secundário:

a) refletir como profissionais de saúde entendem o corpo trans;b) identificar como a população $T$ compreende os cuidados que Ihes são endereçados; c) cartografar a percepção de cuidado voltado

Endereço: Av. Prof. Mello Moraes,1721 - BI. "G" sala 27

Bairro: Cidade Universitária

CEP: $05.508-030$

UF: SP Município: SAO PAULO

Telefone: (11)3091-4182

E-mail: ceph.ip@usp.br 


\section{USP- INSTITUTO DE \\ PSICOLOGIA DA \\ UNIVERSIDADE DE SÃO}

Patoseforma

Continuação do Parecer: 2.431.233

às demandas de alterações corporais na população $T$ por parte dos profissionais envolvidos; d) problematizar e propor espaços de conversação sobre as especificidades de uma clínica que se debruça aos modos do caos no cotidiano de LGBTs.

\section{Avaliação dos Riscos e Benefícios:}

Em relação aos riscos, o pesquisador apresenta a seguinte avaliação:

Riscos:

Apesar da metodologia proposta, até o presente momento, não ter demonstrado riscos a participantes, é possível que efeitos indesejáveis possam ocorrer, apesar de todos os cuidados possíveis. Caso o/a participante venha a sofrer algum efeito indesejável, como resultado direto da sua participação nesta pesquisa, a necessária assistência profissional será providenciada pelo próprio pesquisador ou pelo Laboratório de Estudos em Fenomenologia Existencial e Prática em Psicologia do Instituto de Psicologia da Universidade de São Paulo (LEFE-IPUSP).

Em relação ao benefícios, a seguinte avaliação:

Benefícios:

As orientações e/ou informações encontradas na pesquisa podem servir como medidas de promoção à saúde, bem como diminuir danos à população de travestis, mulheres transexuais e homens trans (seja pelo acompanhamento específico e atento à realidade do cotidiano desta

população ou por uma possível vinculação desta mesma população à atenção básica em saúde).

A descrição e avaliação dos riscos e benefícios podem ser consideradas suficientes e adequadas à legislação vigente.

\section{Comentários e Considerações sobre a Pesquisa:}

A pesquisa está bem redigida e bem fundamentada, apresentando tema de reconhecida importância e relevância na contemporaneidade.

\section{Considerações sobre os Termos de apresentação obrigatória:}

Os termos de apresentação obrigatória foram anexados.

O TCLE está bem redigido e as reformulações sugeridas em parecer anterior foram satisfatoriamente atendidas.

\section{Conclusões ou Pendências e Lista de Inadequações:}

As recomendações de alterações no TCLE foram satisfatoriamente atendidas e o projeto está aprovado.

\section{Considerações Finais a critério do CEP:}

Se o projeto prevê aplicação de TCLE, todas as páginas do documento deverão ser rubricadas pelo

Endereço: Av. Prof. Mello Moraes,1721 - BI. "G" sala 27

Bairro: Cidade Universitária

CEP: $05.508-030$

UF: SP Município: SAO PAULO

Telefone: (11)3091-4182

E-mail: ceph.ip@usp.br 


\section{USP- INSTITUTO DE \\ PSICOLOGIA DA \\ UNIVERSIDADE DE SÃO}

\section{Pataperame}

Continuação do Parecer: 2.431.233

pesquisador e pelo voluntário e a última página assinada por ambos, conforme Carta Circular no 003/2011 da CONEP/CNS.

Salientamos que o pesquisador deve desenvolver a pesquisa conforme delineada no protocolo aprovado.

Eventuais modificações ou emendas ao protocolo devem ser apresentadas ao CEPH de forma clara e sucinta, identificando a parte do protocolo a ser modificada e suas justificativas. Lembramos que esta modificação necessitará de aprovação ética do CEPH antes de ser implementada. De acordo com a Res. CNS 466/12, o pesquisador deve apresentar a este CEP/SMS o relatório final do projeto desenvolvido, conforme preenchimento de Protocolo disponível na página do Comitê de Ética em Pesquisa com Seres Humanos do IPUSP, do site do IPUSP. Em seguida, o protocolo preenchido deverá ser enviado ao $\mathrm{CEPH}$ pela Plataforma Brasil, ícone Notificação, logo que o mesmo estiver concluído.

Este parecer foi elaborado baseado nos documentos abaixo relacionados:

\begin{tabular}{|c|c|c|c|c|}
\hline Tipo Documento & Arquivo & Postagem & Autor & Situação \\
\hline $\begin{array}{l}\text { Informações Básicas } \\
\text { do Projeto }\end{array}$ & $\begin{array}{l}\text { PB_INFORMAÇÖES_BÁSICAS_DO_P } \\
\text { ROJETO 988631.pdf }\end{array}$ & $\begin{array}{c}16 / 11 / 2017 \\
09: 49: 14\end{array}$ & & Aceito \\
\hline Outros & carta_sumariada.docx & $\begin{array}{c}16 / 11 / 2017 \\
09: 46: 54\end{array}$ & Jailton Bezerra Melo & Aceito \\
\hline $\begin{array}{l}\text { TCLE / Termos de } \\
\text { Assentimento / } \\
\text { Justificativa de } \\
\text { Ausência }\end{array}$ & TCLE_CEP_final.docx & $\begin{array}{c}16 / 11 / 2017 \\
09: 46: 29\end{array}$ & \begin{tabular}{|l|} 
Jailton Bezerra Melo \\
\end{tabular} & Aceito \\
\hline Outros & anuencia.pdf & $\begin{array}{c}09 / 10 / 2017 \\
12: 36: 42\end{array}$ & Jailton Bezerra Melo & Aceito \\
\hline $\begin{array}{l}\text { Declaração de } \\
\text { Instituição e } \\
\text { Infraestrutura }\end{array}$ & infraestrutura0001.pdf & $\begin{array}{c}09 / 10 / 2017 \\
12: 25: 10\end{array}$ & Jailton Bez€ & Aceito \\
\hline Folha de Rosto & folha_de_rosto.pdf & $\begin{array}{c}09 / 10 / 2017 \\
12: 24: 45 \\
\end{array}$ & Jailton Bezerra Melo & Aceito \\
\hline Outros & curriculoorientadora.pdf & $\begin{array}{c}15 / 09 / 2017 \\
16: 37: 38 \\
\end{array}$ & Jailton Bezerra Melo & Aceito \\
\hline Outros & curriculopesquisador.pdf & $\begin{array}{l}15 / 09 / 2017 \\
16: 37: 21\end{array}$ & Jailton Bezerra Melo & Aceito \\
\hline $\begin{array}{l}\text { Projeto Detalhado / } \\
\text { Brochura } \\
\text { Investigador }\end{array}$ & PROJETO_CEP.docx & $\begin{array}{c}15 / 09 / 2017 \\
16: 35: 42\end{array}$ & \begin{tabular}{|l|} 
Jailton Bezerra Melo \\
\end{tabular} & Aceito \\
\hline $\begin{array}{l}\text { Declaração de } \\
\text { Pesquisadores }\end{array}$ & declaracao_pesquisador.png & $\begin{array}{c}15 / 09 / 2017 \\
16: 34: 45 \\
\end{array}$ & Jailton Bezerra Melo & Aceito \\
\hline
\end{tabular}

Endereço: Av. Prof. Mello Moraes,1721 - BI. "G" sala 27

Bairro: Cidade Universitária

CEP: $05.508-030$

UF: SP Município: SAO PAULO

Telefone: (11)3091-4182

E-mail: ceph.ip@usp.br 


\section{USP- INSTITUTO DE \\ PSICOLOGIA DA \\ UNIVERSIDADE DE SÃO}

Continuação do Parecer: 2.431.233

Situação do Parecer:

Aprovado

Necessita Apreciação da CONEP:

Não

SAO PAULO, 12 de Dezembro de 2017

Assinado por:

Helena Rinaldi Rosa

(Coordenador)

Endereço: Av. Prof. Mello Moraes,1721 - BI. "G" sala 27

Bairro: Cidade Universitária

CEP: $05.508-030$

UF: SP

Município: SAO PAULO

Telefone: (11)3091-4182

E-mail: ceph.ip@usp.br 